\title{
CALIBRATION, VERIFICATION, AND USE OF A STEADY-STATE STREAM WATER-QUALITY MODEL FOR MONUMENT AND FOUNTAIN CREEKS, EAST-CENTRAL COLORADO
}

by Gerhard Kuhn

U.S. GEOLOGICAL SURVEY

Water-Resources Investigations Report 91-4055

Prepared in cooperation with the

PIKES PEAK AREA COUNCIL OF GOVERNMENTS

Denver, Colorado

1991 


\title{
U.S. DEPARTMENT OF THE INTERIOR
}

\section{MANUEL LUJAN, JR., Secretary}

U.S. GEOLOGICAL SURVEY

\author{
Dallas L. Peck, Director
}

For additional information write to:

\section{District Chief}

U.S. Geological Survey

Box 25046, Mail Stop 415

Federal Center

Denver, CO 80225-0046
Copies of this report can

be purchased from:

U.S. Geological Survey

Books and Open-File Reports Section

Box 25425

Federal Center

Denver, CO 80225-0425 
Abstract-

Introduction-

Purpose and scope-10

Approach-

Description of stream reaches-

Water-quality standards-a

Previous investigations -

Acknowledgments -

Description of steady-state stream water-quality model

Data requirements for calibration and verification of model

Data-collection sites-

Data-collection program-

Preparation of physical data for model input

Traveltime and channel-geometry data-

Reaeration data-

Preparation of water-quality data for model input

Surface water-

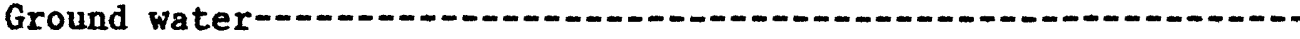

Model estimates of discharge and stream temperature-

Estimated discharges-

Estimated stream temperatures

Calibration and verification of model

Reaction coefficients-....

Method of simulating Colorado Springs Wastewater-Treatment Facility-

Acceptability criteria for calibration and verification-

Results for summer stream reach-

Monument Creek-

Upper Fountain Creek-

Middle Fountain Creek

Results for winter stream reach-

Middle Fountain Creek

Lower Fountain Creek

Estimation of un-ionized ammonia-

Method of estimation-

Results-..-

Estimation of minimum discharges-

Methods of estimation and results

Application of minimum discharges-

Model simulations-

Monument Creek-

Middle Fountain Creek-

Limitations of water-quality model and future data needs-a

Summary-cer

References cited

Supplemental information-

Modification of the model for application to Monument and

Fountain Creeks- 144

Addition of the capability to use a different computationalelement length for each subreach-at

Modification of stream-temperature estimating method-.....

Other modifications to the model-

Computer code for un-ionized ammonia subroutine-

Page 
Figure 1. Map showing location of study area- 3

2. Map showing location of sampling sites on Monument Creek,

Fountain Creek, tributaries, and wastewater outfalls_-..- 12

3-5. Graphs showing discharges for:

3. Monument Creek, July 1987 and July 1986 simulations--- 38

4. Fountain Creek, July 1987 and July 1986 simulations--- 39

5. Fountain Creek, December 1986 and February 1987 simulations - 41

6-8. Graphs showing stream temperatures for:

6. Monument Creek, July 1987 and July 1986 simulations--- 45

7. Fountain Creek, July 1987 and July 1986 simulations--- 46

8. Fountain Creek, December 1986 and February 1987 simulations-... 48

9. Plan view schematic of Fountain Creek in vicinity of

Colorado Springs Wastewater-Treatment Facility-.-...-.

10-39. Graphs showing simulated and measured concentrations of:

10. Total organic nitrogen for Monument Creek, July 1987 and July 1986 simulations-_-

11. Total ammonia as nitrogen for Monument Creek, July 1987 and July 1986 simulations-_an 68

12. Total nitrite as nitrogen for Monument Creek, July 1987 and July 1986 simulations-

13. Total nitrate as nitrogen for Monument Creek, July 1987 and July 1986 simulations-

14. 5-day carbonaceous biochemical oxygen demand for Monument Creek, July 1987 and July 1986 simulations-

15. Dissolved oxygen for Monument Creek, July 1987 and July 1986 simulations-

16. Total organic nitrogen for upper Fountain Creek, July 1987 and July 1986 simulations-_-...

17. Total ammonia as nitrogen for upper Fountain Creek, July 1987 and July 1986 simulations--

18. Total nitrite as nitrogen for upper Fountain Creek, July 1987 and July 1986 simulations -

19. Total nitrate as nitrogen for upper Fountain Creek, July 1987 and July 1986 simulations-_...-

20. 5-day carbonaceous biochemical oxygen demand for upper Fountain Creek, July 1987 and July 1986 simulations-

21. Dissolved oxygen for upper Fountain Creek, July 1987 and July 1986 simulations---

22. Total organic nitrogen for middle Fountain Creek, July 1987 and July 1986 simulations--_.-.

23. Total ammonia as nitrogen for middle Fountain Creek, July 1987 and July 1986 simulations-_-n

24. Total nitrite as nitrogen for middle Fountain Creek, July 1987 and July 1986 simulations-

25. Total nitrate as nitrogen for middle Fountain Creek, July 1987 and July 1986 simulations-

26. 5-day carbonaceous biochemical oxygen demand for middle Fountain Creek, July 1987 and July 1986 simulations-- 
Figures 10-39. Graphs showing simulated and measured concentrations of--

Page Continued:

27. Dissolved oxygen for middle Fountain Creek, July 1987 and July 1986 simulations-_.

28. Total organic nitrogen for middle Fountain Creek, December 1986 and February 1987 simulations-_..- 90

29. Total ammonia as nitrogen for middle Fountain Creek, December 1986 and February 1987

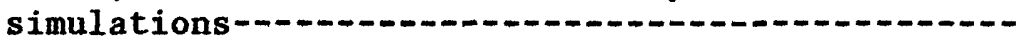

30. Total nitrite as nitrogen for middle Fountain Creek, December 1986 and February 1987 simulations-...-

31. Total nitrate as nitrogen for middle Fountain Creek, December 1986 and February 1987

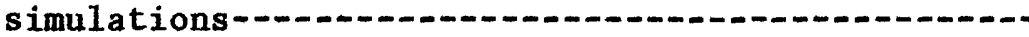

32. 5-day carbonaceous biochemical oxygen demand for middle Fountain Creek, December 1986 and February 1987 simulations

33. Dissolved oxygen for middle Fountain Creek,
December 1986 and February 1987 simulations

34. Total organic nitrogen for lower Fountain Creek, December 1986 and February 1987 simulations--.---

35. Total ammonia as nitrogen for lower Fountain Creek, December 1986 and February 1987

36. Total nitrite as nitrogen for lower Fountain Creek, December 1986 and February 1987

37. Total nitrate as nitrogen for lower Fountain Creek, December 1986 and February 1987 simulations-...-day carbonaceous biochemical oxygen demand for lower Fountain Creek, December 1986 and February 1987 simulations--...

39. Dissolved oxygen for lower Fountain Creek, December 1986 and February 1987 simulations--.---

40-42. Graphs showing estimated and measured $\mathrm{pH}$ values for:

40. Monument Creek, July 1987 and July 1986 simulations-

41. Fountain Creek, July 1987 and July 1986 simulations106

42. Fountain Creek, December 1986 and February 1987 simulations

43-45. Graphs showing estimated and calculated concentrations of un-ionized ammonia as nitrogen for:

43. Monument Creek, July 1987 and July 1986 simulations-

44. Fountain Creek, July 1987 and July 1986 simulations-

45. Fountain Creek, December 1986 and February 1987 simulations-......

46. Graph showing relation between measured instantaneous discharge at site M13.44 Monument Creek at U.S. Air Force Academy Wastewater-Treatment Facility and recorded daily discharge at station 07104000 Monument Creek at Pikeview- 
Figure 47. Graph showing relation between estimated daily discharge

Page at site F43.66 Fountain Creek at Pinello Ranch near Colorado Springs and recorded daily discharge at station 07105500 Fountain Creek at Colorado Springs----

48-50. Graphs showing estimated 1-day and 30-day, 3-year minimum-discharge relations to be used in simulations of summer stream reach for:

48. Monument Creek-

49. Upper Fountain Creek-

Middle Fountain Creek-

51. Estimated 1-day and 7-day, 10-year minimum-discharge relations to be used in simulations of winter stream reach for middle and lower Fountain Creek---

52-57. Graphs showing simulated concentrations of selected water-quality constituents for:

52. Monument Creek using the simulation 1 data-...-.- 128

53. Monument Creek using the simulation 2 data--..--- 129

54. Monument Creek using the simulation 3 data-n- 130

55. Middle Fountain Creek using the simulation 1 data-- 133

56. Middle Fountain Creek using the simulation 2 data-. 134

57. Middle Fountain Creek using the simulation

3 data--.

\section{TABLES}

Table 1. Water-quality standards for selected constituents for

Monument Creek and Fountain Creek- 5

2. Sampling sites on Monument Creek and Fountain Creek-_..... 9

3. Sampling sites on tributaries and wastewater outfalls-_..... 10

4. Physical data for subreaches in the summer stream reach--.--- 22

5. Physical data for subreaches in the winter stream reach--.-.-- 24

6. Measured reaeration coefficients for selected stream reaches on Monument Creek and Fountain Creek

7. Comparison of estimation errors for selected literature reaeration estimating equations for Monument Creek and Fountain Creek-

8. Reaeration estimating equations and model subreaches for which equations are used to estimate stream reaeration--.-.-

9. Averages of water-quality data used for calibrating and verifying the summer stream reach-

10. Averages of water-quality data used for calibrating and verifying the winter stream reach-

11. Sensitivity of simulated concentrations of selected waterquality constituents to a 3 -degree Celsius change in stream temperature at selected sites on Fountain Creek using initial stream temperatures of 25 and 5 degrees Celsius---.-

12. Reaction coefficients determined during calibration for the summer stream reach- 
Table 13. Reaction coefficients determined during calibration for the winter stream reach-_ 56

14. Simulated concentrations of water-quality constituents for selected sites on Fountain Creek using the actual and alternate methods for simulating the Colorado Springs Wastewater-Treatment Facility-

15. Acceptability results for calibrating and verifying the summer stream reach-2 64

16. Acceptability results for calibrating and verifying the winter stream reach- 65

17. Computed annual minimum discharges for selected streamflowgaging stations on Monument Creek and Fountain Creek------ 120

18. Average concentrations of water-quality constituents at sites used in example simulations for Monument Creek- 127

19. Average concentrations of water-quality constituents at sites used in example simulations for middle Fountain Creek-...- 132

CONVERSION FACTORS

Multiply

British thermal unit (BTU)

cubic foot per second $\left(\mathrm{ft}^{3} / \mathrm{s}\right)$

foot ( $f t$ )

foot per second

mile (mi)

mile per hour

second per square foot
By

1,055

0.028317

0.3048

0.3048

1.609

1.609

10.76
To obtain

joule cubic meter per second meter

meter per second

kilometer

kilometer per hour second per square meter

To convert degree Celsius $\left({ }^{\circ} \mathrm{C}\right)$ to degree Fahrenheit $\left({ }^{\circ} \mathrm{F}\right)$, use the following formula:

$$
{ }^{\circ} \mathrm{F}=\frac{9}{5}\left({ }^{\circ} \mathrm{C}\right)+32 \text {. }
$$

The following term and abbreviation also are used in this report: milligram per liter, mg/L. 

CALIBRATION, VERIFICATION, AND USE OF A STEADY-STATE STREAM WATER-QUALITY
MODEL FOR MONUMENT AND FOUNTAIN CREEKS, EAST-CENTRAL COLORADO

By Gerhard Kuhn

ABSTRACT

A one-dimensional, steady-state stream water-quality model was calibrated and verified for Monument and Fountain Creeks, two small streams in the vicinity of Colorado Springs and Pueblo, Colorado. Water-quality constituents considered in the modeling analysis were total organic nitrogen, total ammonia as nitrogen, total nitrite as nitrogen, total nitrate as nitrogen, 5-day carbonaceous biochemical oxygen demand, and dissolved oxygen.

One reach on each of the streams was used to evaluate summer conditions, especially depletion of dissolved oxygen. Another stream reach only on Fountain Creek was used to evaluate winter conditions, especially estimated concentrations of un-ionized ammonia. The model was calibrated and verified for the summer stream reach, except that (1) ammonia and nitrite could not be calibrated for Monument Creek, (2) nitrate could not be calibrated for the upstream reaches of Fountain Creek, and (3) nitrite and nitrate could not be verified for the middle reaches of Fountain Creek. The model was calibrated and verified for all constituents for the winter stream reach except that the ammonia calibration and the organic nitrogen and 5-day carbonaceous biochemical oxygen demand verifications were questionable for the downstream reaches of Fountain Creek.

Minimum stream discharges applicable to the State water-quality standards were estimated. Example simulations were made for Monument Creek and middle Fountain Creek by using the estimated minimum discharges, the reaction coefficients determined for the summer stream reach, and estimated waterquality characteristics data were adjusted differently for two subsequent simulations in order to meet the stream water-quality standards. The example simulations generally indicated that the standards could be met by decreasing the concentration of ammonia at the sites; the needed concentration of nitrate depended on the concentration of ammonia and on the location of a site relative to the other sites.

Several modifications were made to the model for the study. The modifications included: (1) Addition of the capability to use a different computational-element length for each subreach, (2) modification of the method to estimate stream temperature, and (3) addition of a subroutine to estimate concentration of un-ionized ammonia. 


\section{INTRODUCTION}

Population in El Paso and Teller Counties has increased substantially, from about 147,000 in 1960 to about 380,000 in 1985; population for the two counties is projected to be about 565,000 by the year 2000 (Pikes Peak Area Council of Governments, 1986, p. III-5). Although the two counties are not entirely within the Monument and Fountain Creeks basin (fig. 1), about 98 percent of their population is within the basin; about 72 percent of the population in the basin is in the city of Colorado Springs.

Historically, wastewater from communities along Monument and Fountain Creeks has been discharged into the two streams. The quantity of wastewater discharged has increased substantially; daily average discharge by the Colorado Springs Wastewater-Treatment Facility (WWTF) increased from $18.1 \mathrm{ft}^{3} / \mathrm{s}$ during 1965 to $46.4 \mathrm{ft}^{3} / \mathrm{s}$ during 1985.

The recognition that discharge in Monument and Fountain Creeks often is predominantly wastewater and the likelihood of future increases in wastewater discharge led local wastewater-treatment agencies, through the Pikes Peak Area Council of Governments, to sponsor a cooperative agreement with the U.S. Geological Survey, to develop, calibrate, and verify a water-quality model for the two streams. A calibrated and verified water-quality model provides managers and planners with a means to: (1) Determine the effect of present wastewater discharges on Monument and Fountain Creeks and (2) evaluate the effects of projected wastewater discharges on the two streams.

\section{Purpose and Scope}

This report presents descriptions of (1) the assumptions and procedures used to calibrate and verify a steady-state stream water-quality model for Monument and Fountain Creeks, (2) the results of calibrating and verifying the model, and (3) example applications of the water-quality model.

Data used in calibrating and verifying the model were collected on Monument Creek from about 1 mi downstream from the town of Monument downstream to the confluence with Fountain Creek in Colorado Springs; data were collected on Fountain Creek from about $1 \mathrm{mi}$ downstream from the town of Woodland Park downstream to the confluence with the Arkansas River in Pueblo (fig. 1). The summer and winter stream reaches shown in figure 1 are described in the "Description of Stream Reaches" section of this report.

Water-quality constituents that were included in the analyses described in this report are: (1) Total organic nitrogen, (2) total ammonia as nitrogen, (3) total nitrite as nitrogen, (4) total nitrate as nitrogen, (5) 5-day carbonaceous biochemical oxygen demand, and (6) dissolved oxygen. For purposes of subsequent discussions in this report, these water-quality constituents will be referred to by the following simpler terms: (1) Organic nitrogen, (2) ammonia, (3) nitrite, (4) nitrate, (5) 5-day CBOD, and (6) DO. However, in some sections of this report the ionized and un-ionized components of ammonia are discussed. In this instance, the ionized ammonia as nitrogen component will be termed ionized ammonia and the un-ionized ammonia as nitrogen component will be termed un-ionized ammonia. 


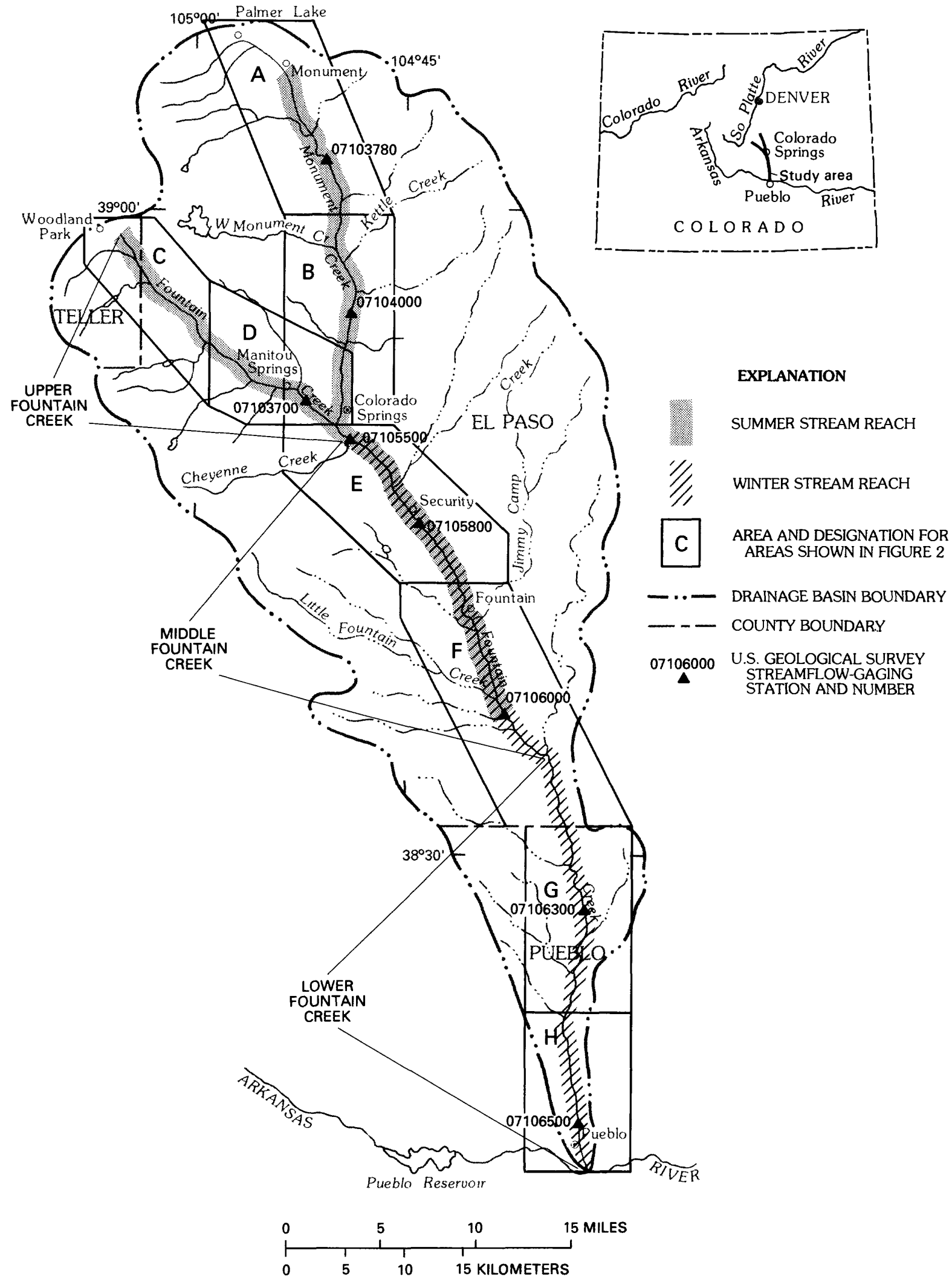

Figure 1.--Location of study area. 


\section{Approach}

The study approach consisted of the following steps: (1) Collection of the physical and water-quality data needed to calibrate and verify the model, (2) compilation and analysis of the data, (3) calibration and verification of the model, (4) estimation of concentrations of un-ionized ammonia, (5) estimation of minimum discharges for Monument and Fountain Creeks, and (6) application of the model to hypothetical situations to demonstrate its use. A detailed description of these steps is given in this report beginning with the section "Data Requirements for Calibration and Verification of Model."

\section{Description of Stream Reaches}

The water-quality model was to be calibrated and verified for summer and for winter conditions; however, the stream reaches (hereinafter referred to as summer stream reach and winter stream reach) for the two conditions were not identical. A summer stream reach (fig. 1) was established for Monument and Fountain Creeks to evaluate summer wastewater-discharge effects, especially Do depletion (Doug Cain, U.S. Geological Survey, written commun., 1986). A winter stream reach (fig. 1) was established only for Fountain Creek to evaluate winter wastewater-discharge effects, especially the possibility of exceeding the water-quality standard of $0.1 \mathrm{mg} / \mathrm{L}$ for un-ionized ammonia in the Arkansas River downstream from Fountain Creek (Colorado Department of Health, $1988 \mathrm{~b}$ ) as a result of (1) the ammonia discharged by the Colorado Springs WWTF and (2) the smaller stream-nitrification rates during winter (Doug Cain, U.S. Geological Survey, written commun., 1986).

The summer stream reach consists of Monument Creek and Fountain Creek downstream to streamflow-gaging station 07106000 Fountain Creek near Fountain (fig. 1). The summer stream reach does not include Fountain Creek from station 07106000 downstream to the mouth because depletion of DO during summer is not substantial in this reach (Doug Cain, U.S. Geological Survey, written commun., 1986).

The winter stream reach consists of Fountain Creek from station 07105500 Fountain Creek at Colorado Springs downstream to the mouth (fig. 1). Monument Creek and Fountain Creek upstream from station 07105500 were not included in the winter stream reach because they were not needed for this part of the modeling analysis.

Primarily for ease of discussion and graphical presentation of the model results, Fountain Creek was divided into upper, middle, and lower sections (fig. 1). Upper Fountain Creek extends from the beginning of the summer stream reach downstream to station 07105500. Middle Fountain Creek extends from station 07105500 downstream to river mile 25.33 (measured upstream from the mouth). Lower Fountain Creek extends from river mile 25.33 downstream to the mouth. In subsequent figures that show the study results, it was convenient to use river mile 25.00 as the division between middle and lower Fountain Creeks. Therefore, lower Fountain Creek between river miles 25.33 and 25.00 is shown in the figures that depict middle Fountain Creek. 


\section{Water-Quality Standards}

The Colorado Department of Health has established water-quality standards for all surface waters throughout the State. Water-quality standards for nitrite, nitrate, un-ionized ammonia, and DO for Monument and Fountain Creeks are listed in table 1 . No water-quality standard for un-ionized ammonia has been established for Fountain Creek downstream from Monument Creek ( and no standards for organic nitrogen, total ammonia, and 5-day CBOD have been established for surface waters (Colorado Department of Health, 1988a).

Table 1.--Water-quality standards for selected constituents for Monument Creek and Fountain Creek

[Source: Colorado Department of Health (1988b). Dashes indicate no applicable standard as of 1988]

\begin{tabular}{|c|c|c|c|c|c|}
\hline \multirow{2}{*}{$\begin{array}{l}\text { Fountain } \\
\text { Creek } \\
\text { stream- } \\
\text { segment } \\
\text { number }\end{array}$} & \multirow{2}{*}{$\begin{array}{c}\text { Stream- } \\
\text { segment } \\
\text { description }\end{array}$} & \multicolumn{4}{|c|}{$\begin{array}{l}\text { Water-quality standard for indicated } \\
\text { constituent, in milligrams per liter }\end{array}$} \\
\hline & & $\begin{array}{l}\text { Total } \\
\text { nitrite as } \\
\text { nitrogen }\end{array}$ & $\begin{array}{l}\text { Total } \\
\text { nitrate as } \\
\text { nitrogen }\end{array}$ & $\begin{array}{l}\text { Un-ionized } \\
\text { ammonia as } \\
\text { nitrogen }\end{array}$ & $\begin{array}{l}\text { Dis- } \\
\text { solved } \\
\text { oxygen }\end{array}$ \\
\hline 7 & $\begin{array}{l}\text { Monument Creek from the } \\
\text { outlet of Monument Lake } \\
\text { downstream to the con- } \\
\text { fluence with Fountain } \\
\text { Creek. }\end{array}$ & 0.5 & 10 & 0.1 & 5.0 \\
\hline 1 & $\begin{array}{l}\text { Fountain Creek from the } \\
\text { source downstream to the } \\
\text { confluence with Monument } \\
\text { Creek. }\end{array}$ & .05 & 10 & .02 & 5.0 \\
\hline 2 & $\begin{array}{l}\text { Fountain Creek from the } \\
\text { confluence with Monument } \\
\text { Creek downstream to the } \\
\text { confluence with the } \\
\text { Arkansas River. }\end{array}$ & 1.0 & 10 & -- & 5.0 \\
\hline
\end{tabular}

${ }^{1}$ Stream segment numbers established by Colorado Department of Health.

The standards for nitrite, nitrate, and un-ionized ammonia (table 1) are maximum standards (concentration should not be greater than the standard), whereas the standard for DO (table 1) is a minimum standard (concentration should not be less than the standard). Water-quality standards apply at all times except when discharge in the streams is less than a specified minimum discharge (Colorado Department of Health, 1988a, p. 24). The specified minimum discharges for Monument and Fountain Creeks and the methods used to estimate them are described in the "Estimation of Minimum Discharges" section of this report. 


\section{Previous Investigations}

Water quality in Monument and Fountain Creeks has been studied extensively during the past 20 years. In the early $1970^{\prime} \mathrm{s}$ a water-resources appraisal, which included a general description of water-quality conditions, was completed for E1 Paso County (Livingston and others, 1975; 1976a; 1976b). At about the same time, a study describing effects of wastewater discharged to Fountain Creek on surface-water quality was completed (Klein and Bingham, 1975).

Monument and Fountain Creeks also have been sampled on a routine basis beginning in 1975 by the U.S. Geological Survey in cooperation with local wastewater-treatment agencies to provide a long-term data base of waterquality data. Data for 1975 through 1985 were summarized statistically and described with emphasis on relation of water quality in Monument and Fountain Creeks to State stream classifications (Edelmann, 1990). In conjunction with that study, sources of increased concentrations of nitrogen in the Widefield aquifer were investigated (Edelmann and Cain, 1985). The Widefield aquifer, which is a part of the Fountain Creek alluvium about 5 mi downstream from Colorado Springs, is an important municipal water supply. Edelmann and Cain (1985, p. 58) concluded that wastewater discharge from the Colorado Springs WWT was the primary source of the increased nitrogen concentrations in the Widefield aquifer. In addition, a study currently (1989) is in progress to determine time trends for selected water-quality constituents in Monument and Fountain Creeks (Stewart, 1987, p. 37).

An analysis of the wasteload assimilative capacity of Monument Creek was completed in 1986 by the Colorado Department of Health (Farrow, 1986). This study was done because Monument Creek was a threatened stream according to water-quality standards (Farrow, 1986, p. 1). This study indicated a large rate of conversion of ammonia to nitrate in Monument Creek (Farrow, 1986, p. 5).

A water-quality model also has been calibrated (Goddard, 1980) and applied to a 42-mi reach of the Arkansas River in Pueblo County (Cain and others, 1980). A calibrated and verified water-quality model for Fountain Creek could benefit future applications of the Arkansas River water-quality model by providing better estimates of the water-quality characteristics of Fountain Creek at the confluence with the Arkansas River.

\section{Acknowledgments}

Appreciation is extended to the many landowners who allowed access to sampling sites on Monument Creek, Fountain Creek, and tributary streams. Access to sampling sites allowed by the city of Colorado Springs at the Colorado Springs WWTF, at Pinello Ranch, and at Hanna Ranch, and access to sampling sites allowed by the towns of Monument, Woodland Park, Security, Widefield, and Fountain at their wastewater-treatment facilities also is acknowledged. Appreciation is extended to the U.S. Air Force Academy for allowing access to sampling sites located at that installation. Special thanks are extended to Kelly Stone, Mary Veatch, and other personnel at the Colorado Springs WWTF Laboratory for doing the 5-day CBOD analyses for the 
hundreds of water samples collected during the study and to Max Grimes for allowing use of the laboratory as a central collection and processing point for the samples. Finally, the assistance of Frank Kipple and Craig Lis, Colorado Division of Water Resources, is acknowledged for data collection.

\section{DESCRIPTION OF STEADY-STATE STREAM WATER-QUALITY MODEL}

The U.S. Environmental Protection Agency QUAL2E water-quality model (Brown and Barnwell, 1987) was used in the study described in this report. This model was used because of its (1) common use, (2) up-to-date documentation, (3) capability to estimate stream temperature, and (4) selection as the standard stream water-quality model used by the Colorado Department of Health.

The QUAL2E model is a one-dimensional, steady-state stream water-quality model capable of simulating as many as 15 water-quality constituents. Brown and Barnwell (1987) present a detailed description of the model and a brief history of its development, which extends almost 20 years. In addition, Hovis and Whittemore (1982) and Whittemore (1985) present a descriptive step-by-step analysis of the model code.

To apply the model, a stream reach to be studied is divided into subreaches, each of which is considered to have uniform hydrologic properties and reaction coefficients. Each subreach consists of one or more computational elements, which are assumed to be completely mixed and linked to one another by advection and dispersion. For each computational element, the model computes the discharge and the mass balance for each water-quality constituent on the basis of: (1) Inflow at the upstream end of the element, (2) inputs to or withdrawals from the element, (3) the outflow at the downstream end of the element, and (4) the appropriate reaction kinetics for each water-quality constituent. The computation technique and the reaction kinetics are described in detail in Brown and Barnwell (1987).

As a part of this study, a number of modifications were made to the QUAL2E mode1. The most notable modifications are: (1) Addition of the capability to use a different computational-element length in each subreach, (2) addition of subreach-variable evaporation coefficients to compute stream temperature, and (3) addition of a subroutine to estimate concentration of un-ionized ammonia. These modifications are described in the "Supplemental Information" section of this report; however, some of the modifications also will be discussed in other appropriate sections of this report.

\section{DATA REQUIREMENTS FOR CALIBRATION AND VERIFICATION OF MODEL}

Before a water-quality model can be applied to a particular stream, the model first must be calibrated and verified by using independent sets of measured water-quality data. The model is calibrated by adjusting the model reaction coefficients so that simulated water quality is in acceptable agreement with the measured water quality of one data set. Another data set then is used to verify the calibrated reaction coefficients; if the simulated 
water quality also is in acceptable agreement with the measured water quality, the model is verified. Once verified, the model can be used to simulate nonmeasured conditions and to evaluate the effects of projected wastewater discharges. The criteria used to determine the acceptability of the calibration and verification simulations are described in the "Acceptability Criteria for Calibration and Verification" section of this report.

\section{Data-Collection Sites}

In order to obtain the independent data sets needed to calibrate and verify the model, an extensive network of data-collection sites was established. Data to define the physical and water-quality characteristics of the hydrologic system, which are needed for model input, were obtained at the data-collection sites. Data obtained to define the physical characteristics are measurements of traveltime, reaeration, channel geometry, discharge, and temperature. Data obtained to define the water-quality characteristics are onsite or laboratory determinations of concentrations of the constituents to be modeled: In addition, some climatologic data also are needed for model input; these data are described in the "Modification of Stream-Temperature Estimating Method" section in the "Supplemental Information" section of this report.

Sites for which traveltime, reaeration, and channel-geometry data were obtained are not described in this report because these sites are not used directly in the model; these sites are described in Kuhn and Ortiz (1989). However, some of the traveltime, reaeration, and channel-geometry sites are the same as the sites for which water-quality data were obtained (Kuhn and Ortiz, 1989). All sites for which discharge and temperature data were obtained are the same as the water-quality sampling sites described in the next paragraph.

Water-quality sampling sites were established for selected locations on Monument and Fountain Creeks (table 2) and for perennial tributaries and all wastewater outfalls (table 3 ). The site numbers listed in tables 2 and 3 are given in river miles upstream from the mouth of Monument Creek or Fountain Creek, proceeded by one or two letters that indicate whether the site is on Monument Creek (M), on a tributary to Monument Creek (MT), on Fountain Creek (F), or on a tributary to Fountain Creek (FT). Ditches and pipelines (diversions) also are listed in table 3 because they are included in the input data; however, these sites were not sampled because the simulated stream water-quality characteristics at the point of diversion are used to characterize the water quality of the diversion. Wastewater outfalls and diversions are considered tributaries for site-number purposes. Locations of the sites are shown in figure 2 (areas $A-H$ ). Because of access limitations, some tributary streams were not sampled at the mouth (fig. 2, areas $A-H$ ), even though the site numbers always indicate the river miles (along Monument or Fountain Creeks) at the mouth of the tributaries. 
Table 2.--Sampling sites on Monument Creek and Fountain Creek

[Sampling-site numbers are listed by river miles upstream from the mouth of Monument Creek or Fountain Creek. M, Monument Creek site; F, Fountain Creek site; WWTF, wastewater-treatment facility]

\begin{tabular}{|c|c|}
\hline $\begin{array}{l}\text { Sampling- } \\
\text { ite number } \\
\text { (figure } 2 \text { ) }\end{array}$ & Site name \\
\hline $\begin{array}{l}\text { M23.68 } \\
\text { M22.02 } \\
\text { M20.39 } \\
\text { M18.56 }\end{array}$ & $\begin{array}{l}\text { Monument Creek above Tri-Lakes WWTF outfall near Monument } \\
\text { Monument Creek at Baptist Road near Monument } \\
\text { Monument Creek below Beaver Creek near Monument } \\
\text { Monument Creek above Northgate Boulevard at U.S. Air Force Academy } \\
\text { (streamflow-gaging station } 07103780 \text { ) } \\
\text { Monument Creek above Smith Creek at U.S. Air Force Academy }\end{array}$ \\
\hline $\begin{array}{r}\text { M13.44 } \\
\text { M11.43 } \\
\text { M7. } 34 \\
\text { M3.69 } \\
\text { M0.00 }\end{array}$ & $\begin{array}{l}\text { Monument Creek at U.S. Air Force Academy WWTF } \\
\text { Monument Creek above West Monument Creek at U.S. Air Force Academy } \\
\text { Monument Creek at Pikeview (streamflow-gaging station 07104000) } \\
\text { Monument Creek at Fillmore Street at Colorado Springs } \\
\text { Monument Creek at the mouth at Colorado Springs }\end{array}$ \\
\hline $\begin{array}{l}\text { F67.76 } \\
\text { F67.28 } \\
\text { F66.52 } \\
\text { F } 64.58 \\
\text { F } 60.74\end{array}$ & $\begin{array}{l}\text { Fountain Creek below Woodland Park WWT outfall near Woodland Park } \\
\text { Fountain Creek near Crystola } \\
\text { Fountain Creek above Crystola Creek at Crystola } \\
\text { Fountain Creek above Catamount Creek at Green Mountain Falls } \\
\text { Fountain Creek above Cascade Creek at Cascade }\end{array}$ \\
\hline $\begin{array}{l}\text { F56.90 } \\
\text { F53.84 }\end{array}$ & $\begin{array}{l}\text { Fountain Creek above Manitou Springs } \\
\text { Fountain Creek near Colorado Springs } \\
\quad \text { (streamflow-gaging station } 07103700 \text { ) }\end{array}$ \\
\hline $\begin{array}{l}\text { F50.61 } \\
\text { F49.34 }\end{array}$ & $\begin{array}{l}\text { Fountain Creek above Monument Creek at Colorado Springs } \\
\text { Fountain Creek at Colorado Springs } \\
\text { (streamflow-gaging station } 07105500 \text { ) }\end{array}$ \\
\hline F47.61 & Fountain Creek above Spring Creek at Colorado Springs \\
\hline $\begin{array}{l}\text { F45.22 } \\
\text { F43.66 } \\
\text { F40.98 } \\
\text { F39. } 31\end{array}$ & $\begin{array}{l}\text { Fountain Creek at Highway } 85 \text { near Colorado Springs } \\
\text { Fountain Creek at Pinello Ranch near Colorado Springs } \\
\text { Fountain Creek above Security WWTF outfall near Security } \\
\text { Fountain Creek at Security (streamflow-gaging station 07105800) } \\
\text { Fountain Creek above Widefield WWTF outfall near Widefield }\end{array}$ \\
\hline $\begin{array}{l}\text { F37.43 } \\
\text { F34.27 } \\
\text { F31.38 } \\
\text { F29.47 } \\
\text { F25.25 }\end{array}$ & $\begin{array}{l}\text { Fountain Creek above Fountain } \\
\text { Fountain Creek above Fountain WWTF outfall near Fountain } \\
\text { Fountain Creek above Little Fountain Creek near Fountain } \\
\text { Fountain Creek near Fountain (streamflow-gaging station 07106000) } \\
\text { Fountain Creek above Williams Creek near Wigwam }\end{array}$ \\
\hline $\begin{array}{r}\text { F20.85 } \\
\text { F15.00 } \\
\text { F10.90 } \\
\text { F6.95 } \\
\text { F2.60 }\end{array}$ & $\begin{array}{l}\text { Fountain Creek above Totten Ranch near Pinon } \\
\text { Fountain Creek near Pinon (streamflow-gaging station 07106300) } \\
\text { Fountain Creek above Greenview Ditch near Bragdon } \\
\text { Fountain Creek at Belmont Stables near Pueblo } \\
\text { Fountain Creek at Pueblo (streamflow-gaging station 07106500) }\end{array}$ \\
\hline F0.00 & Fountain Creek at the mouth at Pueblo \\
\hline
\end{tabular}


Table 3.--Sampling sites on tributaries and wastewater outfalls

[Site numbers are listed in river miles upstream from the mouth of Monument Creek or Fountain Creek. MT, Monument Creek tributary site; FT, Fountain Creek tributary site. Types of sites are: $W$, wastewater outfall; $T$, tributary; $D$, diversion. WWTF, wastewater-treatment facility]

\begin{tabular}{|c|c|c|}
\hline $\begin{array}{l}\text { Sampling- } \\
\text { site } \\
\text { number } \\
\text { (figure 2) }\end{array}$ & $\begin{array}{l}\text { Type } \\
\text { of } \\
\text { site }\end{array}$ & Site name \\
\hline
\end{tabular}

MT23.67

MT21.21

$\operatorname{MT} 19.76$

MT19.66

MT19.17

${ }^{1} \mathrm{MT} 18.37$

${ }^{2} \mathrm{MT} 17.45$

MT17.16

MT14.89

MT13.43

MT11. 42

MT10.52

MT9.06

MT8.18

MT6.13

MT4.95

MT4.88

MT4.36

FT68.10

FT68.09

FT67.75

FT66.51

FT66.13

FT64.57

FT64. 48

FT60.73

FT5 9.90

FT56.28

FT5 4.98

FT53.83

FT53.39

FT50.17

FT49.33

FT49.04

FT48.67
Tri-Lakes WWTF outfall near Monument

Beaver Creek at the mouth near Monument Jackson Creek at the mouth near U.S. Air Force Academy Forest Lakes/Triview WWTF outfall near U.S. Air Force Academy Unnamed tributary below Jackson Creek at U.S. Air Force Academy

$\mathrm{T}, \mathrm{W}$

$\mathrm{T}, \mathrm{W}$

$T$

$\mathrm{T}$

W

Unnamed tributary above Smith Creek at U.S. Air Force Academy

Smith Creek at the mouth at U.S. Air Force Academy

Deadmans Creek at the mouth at U.S. Air Force Academy

Black Squirrel Creek near the mouth at U.S. Air Force Academy

U.S. Air Force Academy WWT outfall at U.S. Air Force Academy

$\mathrm{T}$

$\mathrm{T}$

$T$

T

D

West Monument Creek at the mouth at U.S. Air Force Academy

Kettle Creek near the mouth near Colorado Springs

Pine Creek near the mouth near Colorado Springs

Cottonwood Creek at the mouth at Pikeview

Monument Creek pipeline at Colorado Springs

$T$

Templeton Gap Floodway at the mouth at Colorado Springs

Douglas Creek at the mouth at Colorado Springs

Unnamed tributary below Douglas Creek at Colorado Springs

Woodland Park WWTF outfall near Woodland Park

Woodland Acres WWTF outfall near Woodland Park

Unnamed tributary below Woodland Park WWTF outfall near Woodland Park Crystola Creek at the mouth at Crystola

Unnamed tributary below Crystola Creek near Crystola

Catamount Creek at the mouth at Green Mountain Falls

Crystal Creek at the mouth at Green Mountain Falls

Cascade Creek at the mouth at Cascade

French Creek at the mouth near Cascade

Ruxton Creek near the mouth at Manitou Springs

Sutherland Creek at the mouth at Manitou Springs

El Paso pipeline at Colorado Springs

Camp Creek near mouth at Colorado Springs

Bear Creek near the mouth at Colorado Springs

Cheyenne Creek at the mouth at Colorado Springs

Shooks Run near the mouth at Colorado Springs

W Colorado Springs WWTF outfall at Colorado Springs 
Table 3.--Sampling sites on tributaries and wastewater outfalls--Continued

\begin{tabular}{ccc}
$\begin{array}{c}\text { Sampling- } \\
\text { site }\end{array}$ & $\begin{array}{c}\text { Type } \\
\text { of }\end{array}$ & Site name \\
number & site & \\
(figure 2) & & \\
\hline
\end{tabular}

\begin{tabular}{|c|c|c|}
\hline $\begin{array}{l}\text { FT48.66 } \\
\text { FT48.46 } \\
\text { FT47.74 } \\
\text { FT47.60 } \\
\text { FT46.93 }\end{array}$ & $\begin{array}{l}\mathrm{D} \\
\mathrm{T} \\
\mathrm{T} \\
\mathrm{T} \\
\mathrm{W}\end{array}$ & $\begin{array}{l}\text { Fountain Mutual Canal at diversion at Colorado Springs } \\
\text { Fountain Mutual Canal sluice at Colorado Springs } \\
\text { Spring Run at mouth at Colorado Springs } \\
\text { Spring Creek at the mouth at Colorado Springs } \\
\text { Garden Valley WWT outfall at Colorado Springs }\end{array}$ \\
\hline $\begin{array}{l}\text { FT46.50 } \\
\text { FT45.63 } \\
\text { FT45.01 } \\
\text { FT44.62 } \\
\text { FT43.23 }\end{array}$ & $\begin{array}{l}\mathrm{T} \\
\mathrm{T} \\
\mathrm{T} \\
\mathrm{D} \\
\mathrm{T}\end{array}$ & $\begin{array}{l}\text { Unnamed tributary below Circle Drive at Colorado Springs } \\
\text { Sand Creek near the mouth at Colorado Springs } \\
\text { Unnamed tributary at Highway } 85 \text { near Colorado Springs } \\
\text { Stubbs and Miller Ditch at Colorado Springs } \\
\text { B Ditch drain near the mouth near Colorado Springs }\end{array}$ \\
\hline $\begin{array}{l}\text { FT 40.97 } \\
\text { FT39.97 } \\
\text { FT39.53 } \\
\text { 3FT39.52 } \\
\text { FT39.08 }\end{array}$ & $\begin{array}{l}W \\
T \\
W \\
T, W\end{array}$ & $\begin{array}{l}\text { Security WWTF outfall near Security } \\
\text { Unnamed tributary near Widefield } \\
\text { Widefield WWTF outfall near Widefield } \\
\text { Clover Ditch drain near Widefield } \\
\text { Chilcotte, Miller, and Crabb Ditches near Fountain }\end{array}$ \\
\hline $\begin{array}{l}\text { FT38.52 } \\
\text { FT36.33 } \\
\text { FT35.69 } \\
\text { FT35.20 } \\
\text { FT34.26 }\end{array}$ & $\begin{array}{l}T \\
T \\
D \\
T \\
W\end{array}$ & $\begin{array}{l}\text { Chilcotte Ditch sluice near Fountain } \\
\text { Unnamed tributary at Fountain } \\
\text { Lock Ditch at Fountain } \\
\text { Jimmy Camp Creek at the mouth near Fountain } \\
\text { Fountain WWTF outfall near Fountain }\end{array}$ \\
\hline $\begin{array}{l}\text { FT33. } 70 \\
\text { FT33. } 12 \\
\text { FT30.32 } \\
\text { FT30.06 } \\
\text { FT29.23 }\end{array}$ & $\begin{array}{l}\text { D } \\
\text { D } \\
\text { T } \\
\text { D } \\
\text { D }\end{array}$ & $\begin{array}{l}\text { Liston and Love (north) Ditch near Fountain } \\
\text { Owen and Hall Ditch near Fountain } \\
\text { Little Fountain Creek near the mouth near Fountain } \\
\text { Liston and Love (south) Ditch near Fountain } \\
\text { Talcott and Cotton Ditch near Fountain }\end{array}$ \\
\hline $\begin{array}{l}\text { FT26.50 } \\
\text { FT25.15 } \\
\text { FT24.20 } \\
\text { FT24.00 } \\
\text { FT20.84 }\end{array}$ & $\begin{array}{l}\mathrm{D} \\
\mathrm{T} \\
\mathrm{T} \\
\mathrm{D} \\
\mathrm{D}\end{array}$ & $\begin{array}{l}\text { Robinson Ditch near Buttes } \\
\text { Williams Creek at the mouth near Wigwam } \\
\text { Unnamed tributary near Wigwam } \\
\text { Burke Ditch near Wigwam } \\
\text { Wood Valley Ditch near Wigwam }\end{array}$ \\
\hline $\begin{array}{r}\text { FT16.88 } \\
\text { FT14.00 } \\
\text { FT10.89 } \\
\text { FT8.80 }\end{array}$ & $\begin{array}{l}\text { D } \\
\text { D } \\
\text { D } \\
\text { D }\end{array}$ & $\begin{array}{l}\text { Sutherland, Lincoln, and McNeil Ditches near Pinon } \\
\text { Caulfield and Olin Ditches near Pinon } \\
\text { Greenview Ditch near Pinon } \\
\text { Cactus Ditch near Pueblo }\end{array}$ \\
\hline
\end{tabular}

${ }^{1}$ Donala WWT discharges into this tributary.

${ }^{2}$ Academy WWT discharges into Smith Creek.

${ }^{3}$ Fort Carson WWTF discharges into Clover Ditch drain. 


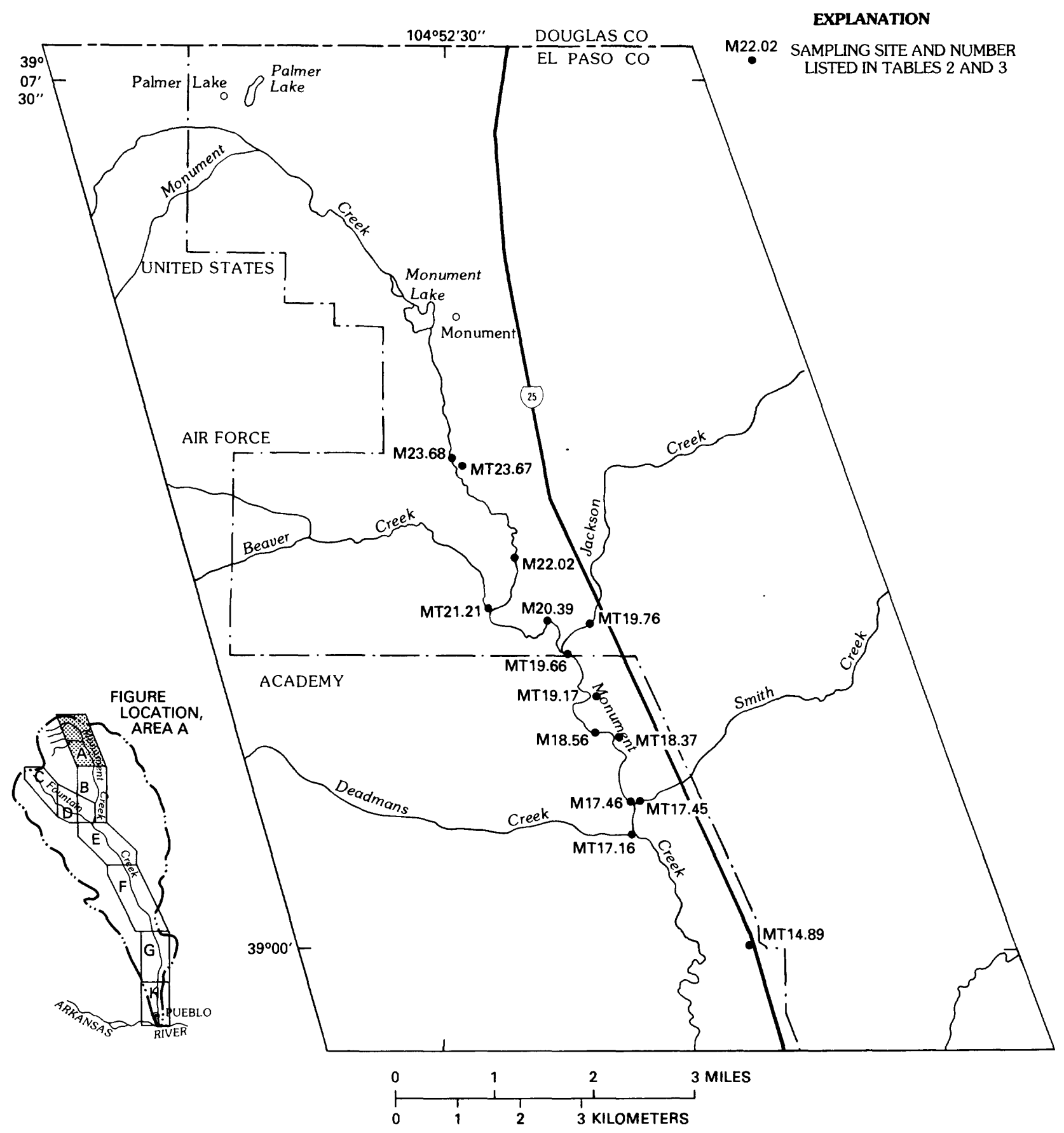

Figure 2.--Location of sampling sites on Monument Creek, Fountain Creek, tributaries, and wastewater outfalls, area $\mathrm{A}$. 


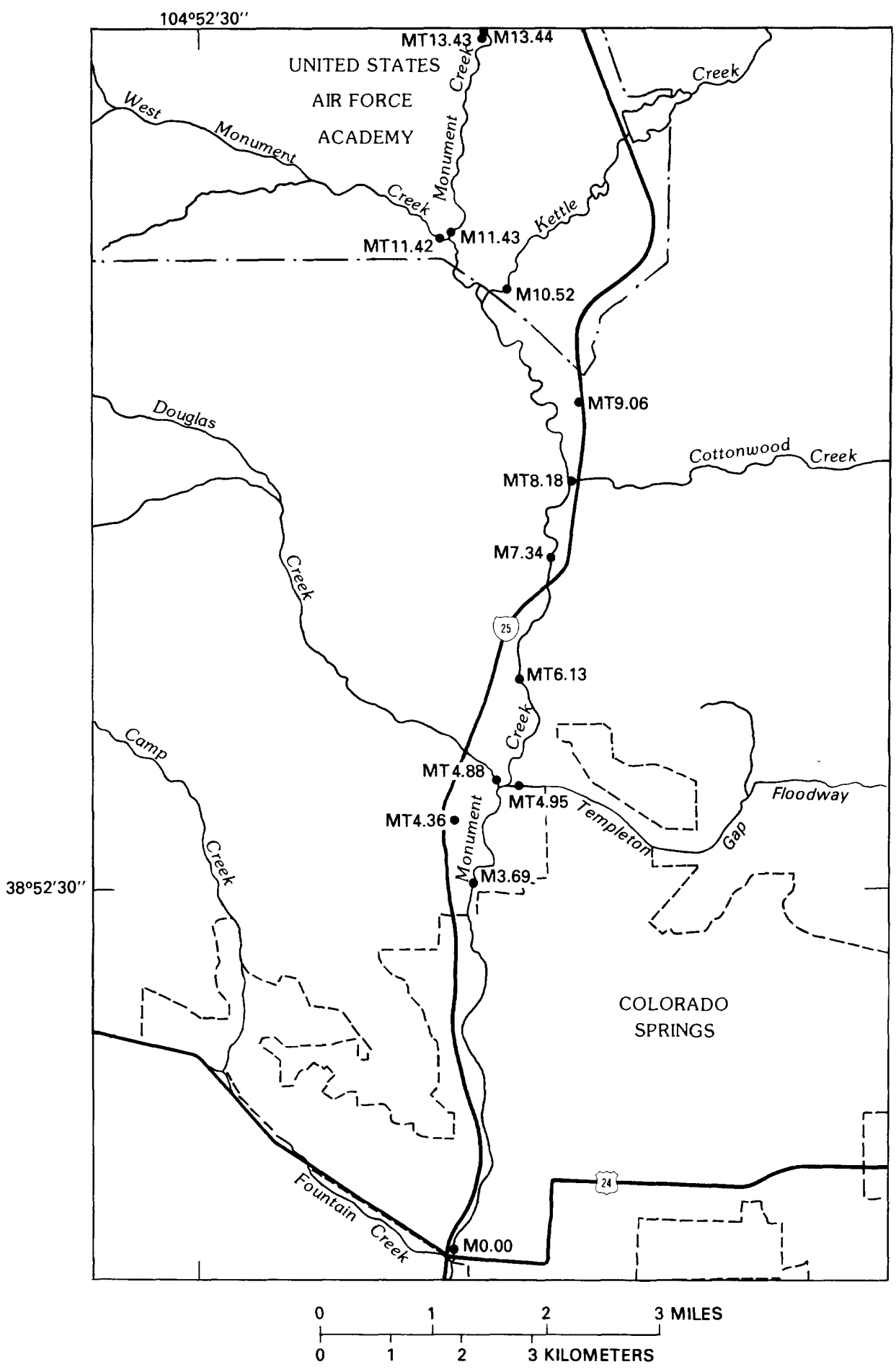

$\begin{array}{cc} & \text { EXPLANATION } \\ \text { M7.34 } & \text { SAMPLING SITE AND NUMBER } \\ \text { LISTED IN TABLES 2 AND 3 }\end{array}$

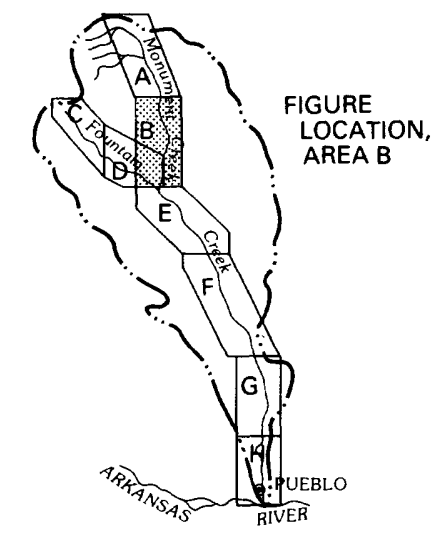

Figure 2.--Location of sampling sites on Monument Creek, Fountain Creek, tributaries, and wastewater outfalls, area B--Continued. 


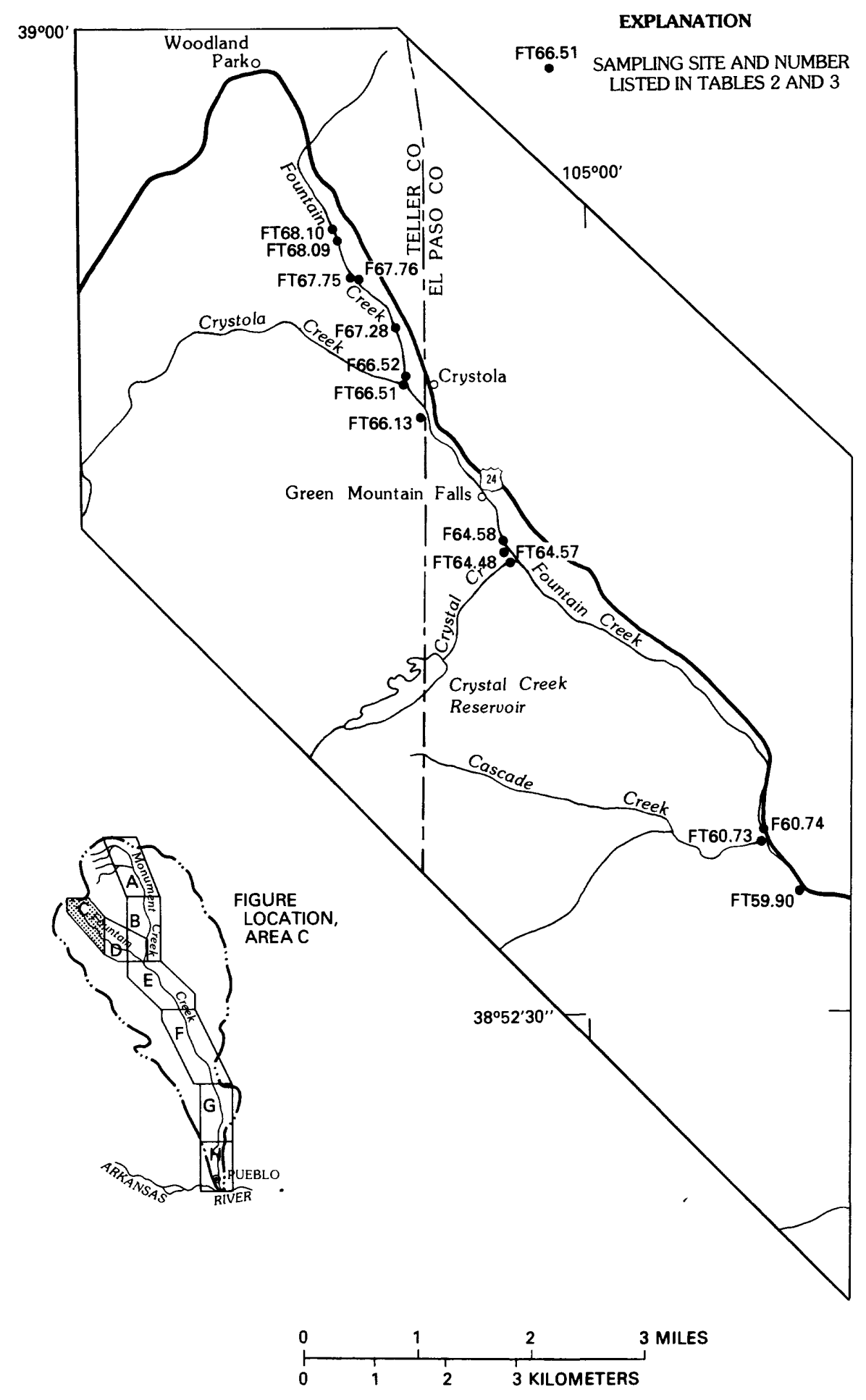

Figure 2.--Location of sampling sites on Monument Creek, Fountain Creek, tributaries, and wastewater outfalls, a rea $\mathrm{C}-$--Continued. 


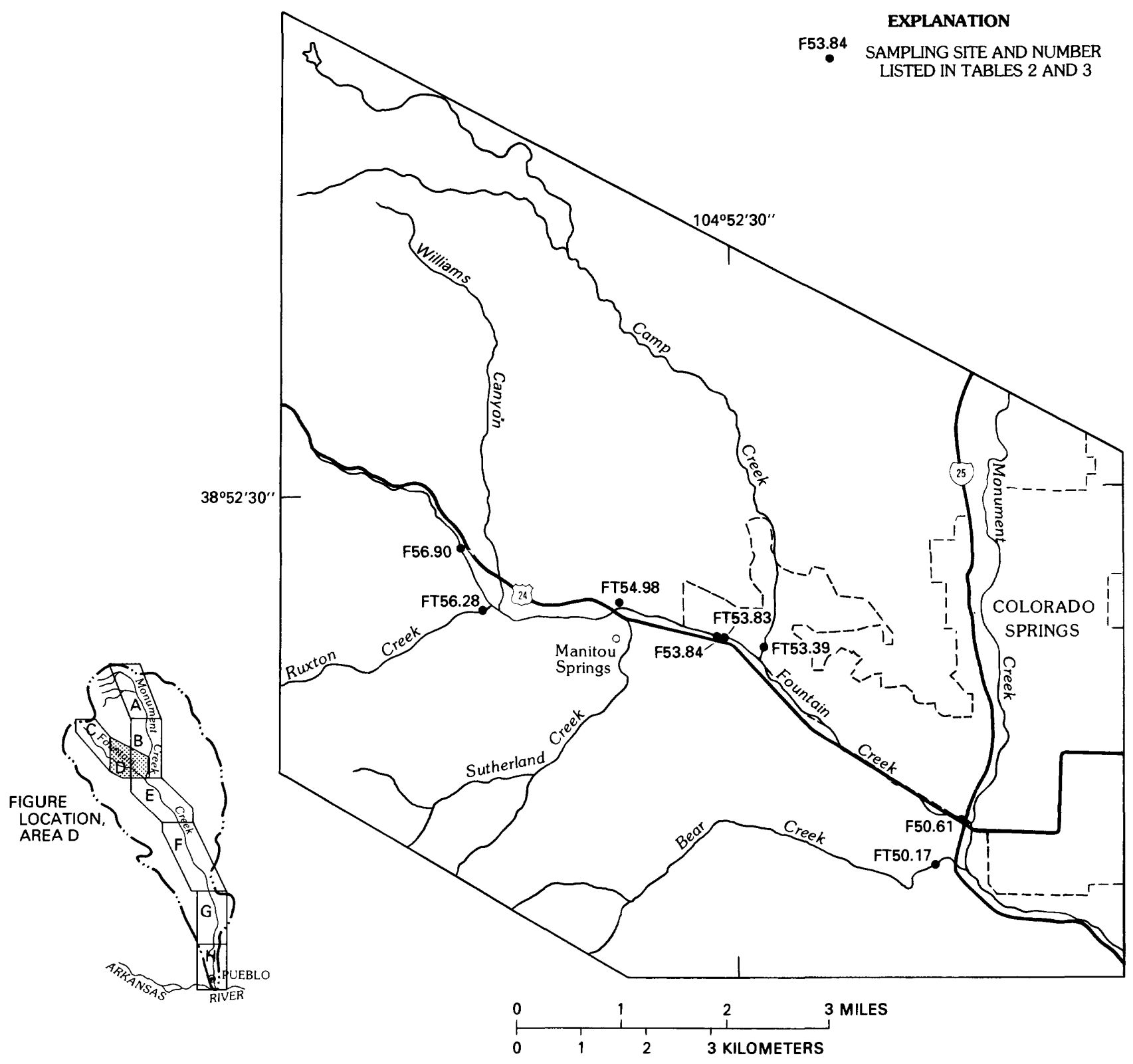

Figure 2.--Location of sampling sites on Monument Creek, Fountain Creek, tributaries, and wastewater outfalls, area D--Continued. 


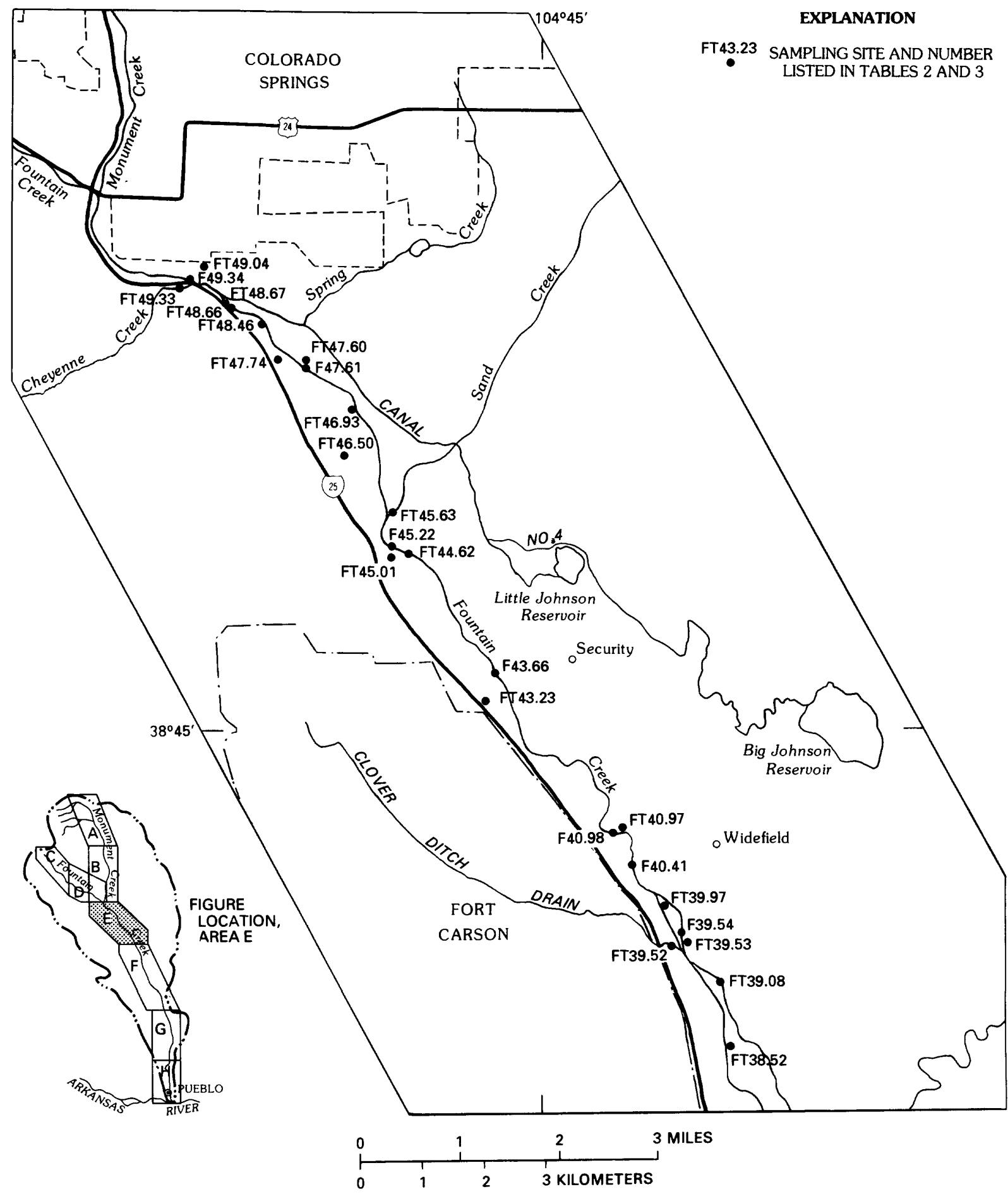

Figure 2.--Location of sampling sites on Monument Creek, Fountain Creek, tributaries, and wastewater outfalls, area E--Continued. 


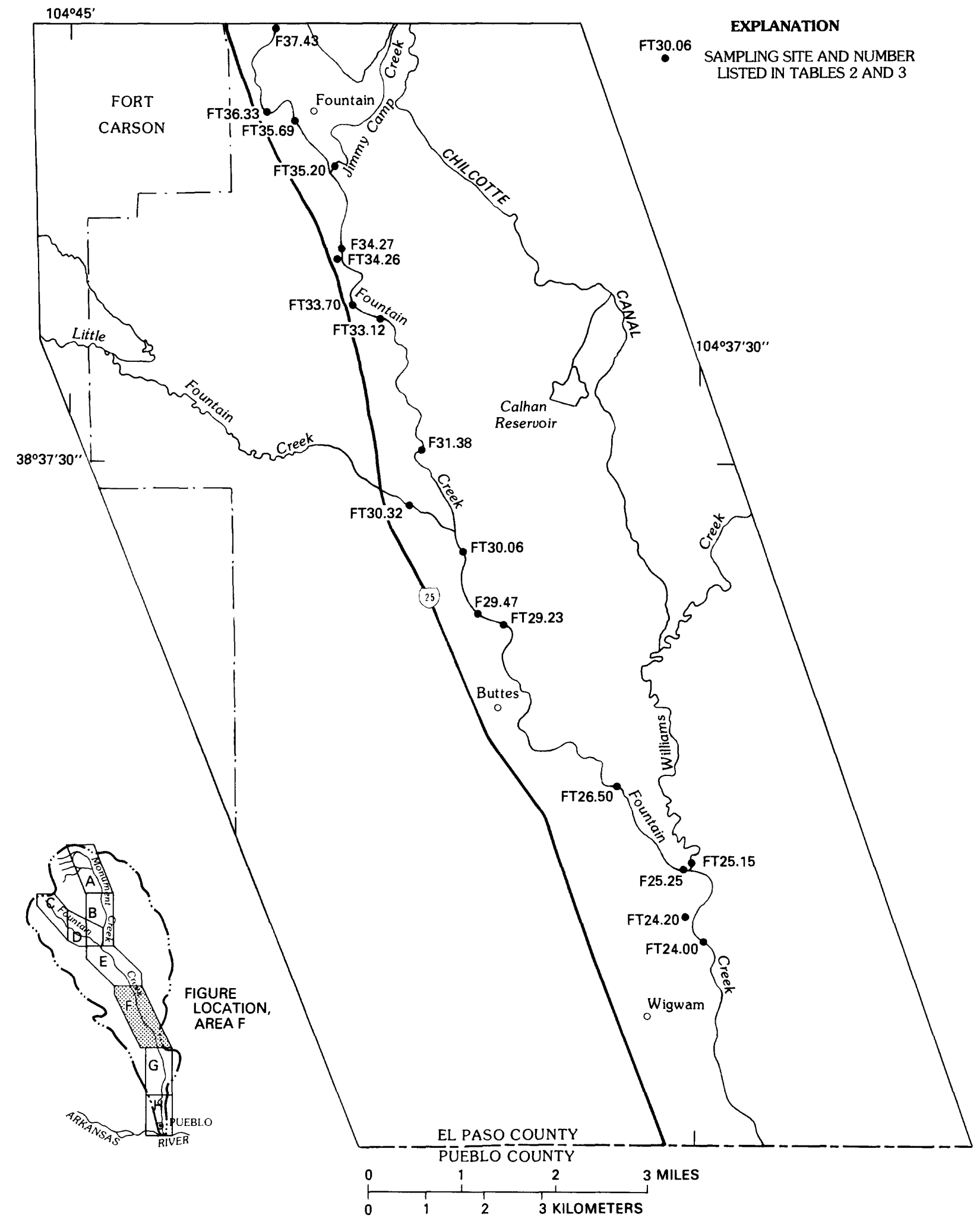

Figure 2.--Location of sampling sites on Monument Creek, Fountain Creek, tributaries, and wastewater outfalls, area F--Continued. 
F15.00 SAMPLING SITE AND NUMBER

- LISTED IN TABLES 2 AND 3

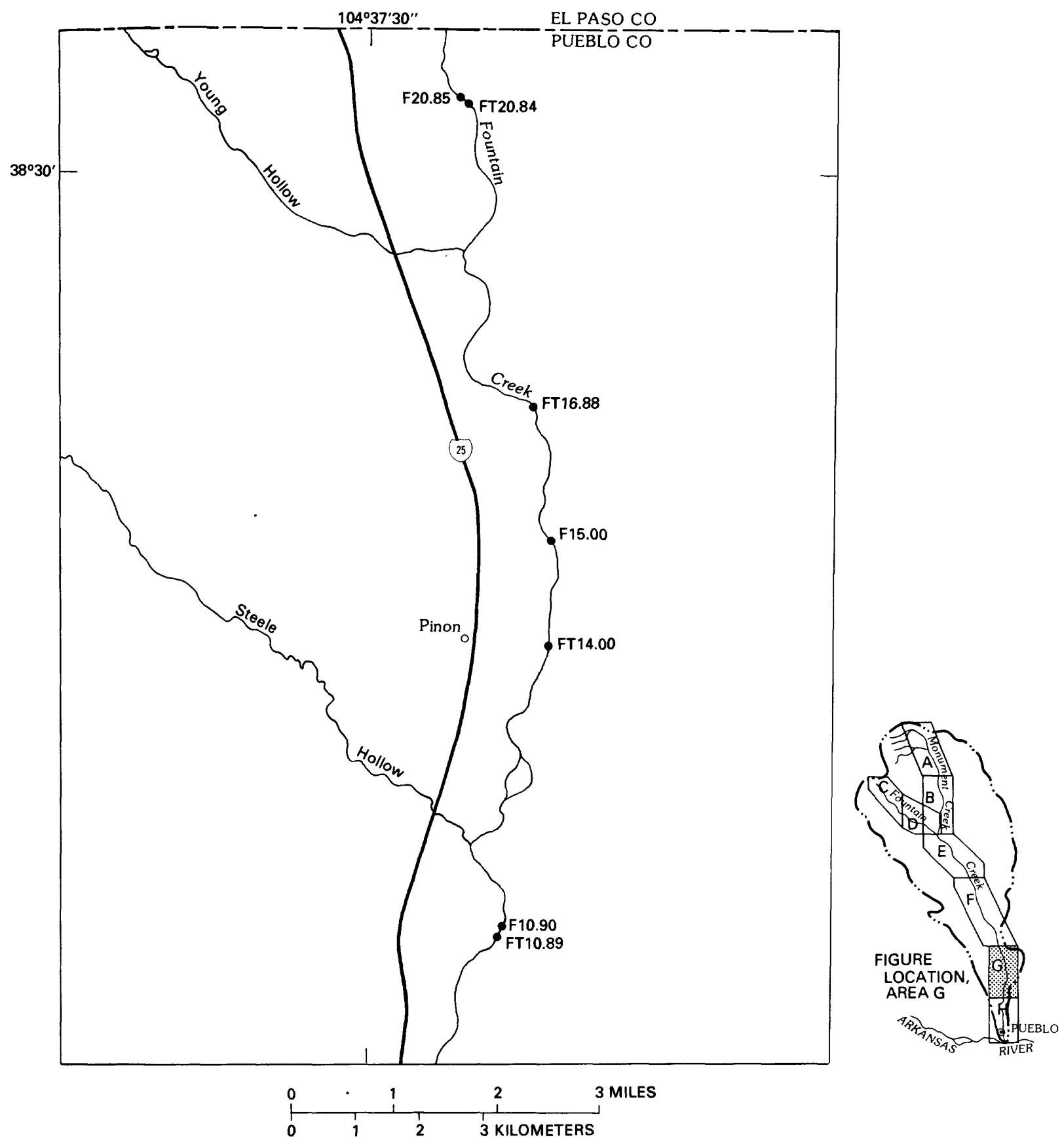

Figure 2.--Location of sampling sites on Monument Creek, Fountain Creek, tributaries, and wastewater outfalls, area G--Continued. 


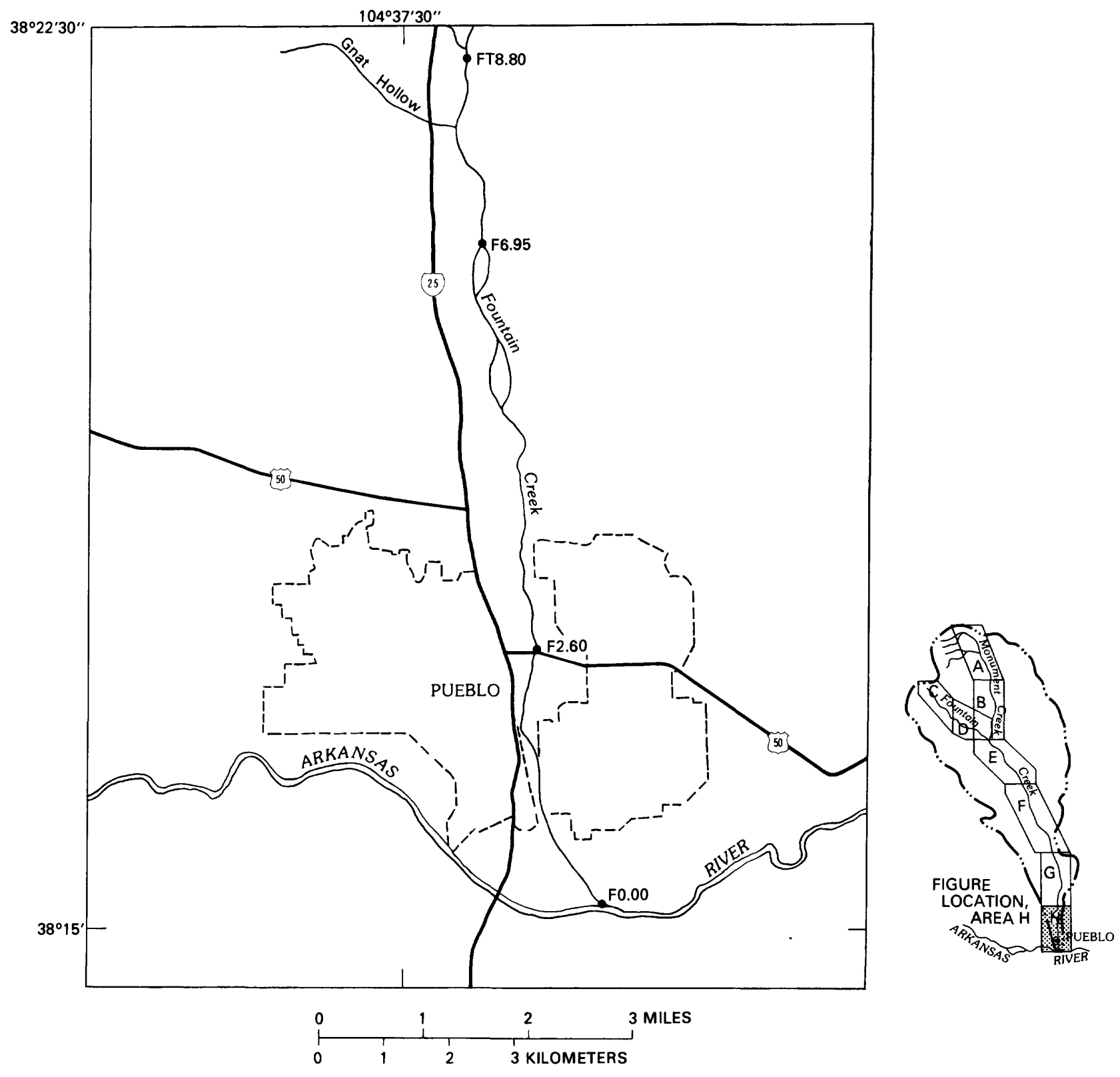

Figure 2.--Location of sampling sites on Monument Creek, Fountain Creek, tributaries, and wastewater outfalls, area H--Continued. 


\section{Data-Collection Program}

Traveltime data were obtained during July and October 1986; April, August, September, and October 1987; and May 1988. Traveltime measurements were made by injecting a fluorescent dye (rhodamine WT) into Monument and Fountain Creeks at selected sites and by collecting samples at downstream sites for analysis of dye concentration. Hubbard and others (1982) describe the techniques for traveltime measurements used in this study.

Reaeration measurements were made in conjunction with the traveltime measurements during October 1986 and April 1987. Propane and ethylene gases also were injected at sites on the two creeks, and samples were collected at downstream sites for analysis of the gases. Kilpatrick and others (1989) describe the techniques for reaeration measurements used in this study.

Measurements of channel geometry, which provided stream-depth data, were made at selected stream cross sections during the reaeration measurements, as well as during times of water-quality sampling. Discharge and stream temperature data for model input were obtained during times of water-quality sampling. Kuhn and Ortiz (1989) list the traveltime, reaeration, and channelgeometry data obtained for this study.

Water-quality, discharge, and stream-temperature data used to calibrate and verify the model were obtained during four 24-hour (diel) sampling periods during 1986 and 1987 . Two data sets were obtained for each of the two stream reaches (fig. 1); data for the summer stream reach were obtained during July 15-16, 1986, and during July 20-21, 1987. The July 1987 data set was used to calibrate the model because more discharge data were obtained for some of the sampling sites than for the July 1986 data set, which was used to verify the model. For the winter stream reach, the calibration data set was obtained during December 9-10, 1986, and the verification data set was obtained during February 10-11, 1987.

The frequency of sampling at the sites varied, depending on the importance of the site to the modeling analysis and on the expected variations in concentration of the water-quality constituents. Generally, sites on Monument and Fountain Creeks and on wastewater outfalls were sampled at about 4-hour intervals, whereas sites on tributaries were sampled one, two, or three times during the 24-hour period. Onsite measurements of specific conductance, $\mathrm{pH}$, stream temperature, and concentration of DO were made when each sample was collected.

Collected samples were analyzed for organic nitrogen plus ammonia (Kjeldahl analysis), ammonia, nitrite, nitrite plus nitrate, and 5-day CBOD. Organic nitrogen was calculated from organic nitrogen plus ammonia and ammonia; nitrate was calculated from nitrite and nitrite plus nitrate. Samples for nitrogen species were analyzed by the U.S. Geological Survey Water-Quality Laboratory in Arvada, Colo., by using the methods described in Fishman and Friedman (1989). Samples for 5-day CBOD were analyzed by the Colorado Springs WWTF Laboratory by using the methods described in American Public Health Association and others (1985, p. 525-531).

During each diel-sampling period, two discharge measurements usually were made at sites on Monument and Fountain Creeks; also, the stage (depth) at each site was recorded from temporary staff gages installed at the sites at the 
time of sampling. One or two discharge measurements were made at tributary sites during each diel-sampling period. Discharges for each wastewater site were provided by the plant operators; discharges for diversions were provided by the Colorado Division of Water Resources and the city of Colorado Springs, Department of Utilities. All water-quality, discharge, and stream-temperature data obtained for calibrating and verifying the model are presented in Kuhn and Ortiz (1989).

\section{Preparation of Physical Data for Model Input}

The following two subsections of this report present descriptions of how the traveltime, channel-geometry, and reaeration data were prepared for input to the QUAL2E model. How the discharge data were prepared for input is described in the "Estimated Discharges" section of this report and how the stream-temperature data were prepared is described in the "Preparation of Water-Quality Data for Model Input" section.

\section{Traveltime and Channel-Geometry Data}

The QUAL2E model provides for two methods to characterize the physical regime of a stream, either by using discharge coefficients and exponents or by using a trapezoidal cross section (Brown and Barnwe11, 1987, p. 15-16). The discharge coefficients and exponents method was selected for use in the analysis described in this report. When using this method, stream transport velocity (traveltime) for each subreach is computed by using the equation (Brown and Barnwel1, 1987, p. 15):

$$
\overline{\mathrm{U}}=\mathrm{c}_{\mathbf{u}} \mathrm{Q}^{\left(\mathrm{e}_{\mathrm{u}}\right)} \text {, }
$$

and stream depth is computed by using the equation (Brown and Barnwell, 1987, p. 15):

$$
H=c_{h} Q^{\left(e_{h}\right)} \text {, }
$$

where

$$
\begin{aligned}
\bar{U} & =\text { average stream transport velocity, in feet per second; } \\
H & =\text { average stream depth, in feet; } \\
Q & =\text { discharge, in cubic feet per second; } \\
c_{u} & =\text { empirically derived discharge coefficient, in feet }{ }^{-2} ; \\
c_{h} & =\text { empirically derived discharge coefficient, } \\
e_{u}, e_{h} & =\text { in seconds per square foot; and }
\end{aligned}
$$

The discharge coefficients and exponents used to compute velocity and depth often can be derived from stage-discharge data available for streamflowgaging stations. However, the few gaging stations on Monument and Fountain Creeks (fig. 1) are insufficient to define the complete range of physical conditions along the two streams. Moreover, use of the stage-discharge relation to define these coefficients and exponents only provides velocity and depth at an isolated point along a stream, which typically is not representative of a longer stream reach. Consequently, the traveltime, channel-geometry, and discharge data obtained for this study (Kuhn and Ortiz, 1989) were used to derive the discharge coefficients and exponents for the model subreaches (tables 4 and 5 ). 
Table 4.--Physical data for subreaches in the summer stream reach

[River miles are measured upstream from the mouth of either Monument Creek or Fountain Creek; --, not applicable]

\begin{tabular}{|c|c|c|c|c|c|c|c|c|c|}
\hline \multirow{2}{*}{$\begin{array}{l}\text { Model } \\
\text { sub- } \\
\text { reach } \\
\text { number }\end{array}$} & \multicolumn{2}{|c|}{$\begin{array}{l}\text { River mile at } \\
\text { ends of subreach }\end{array}$} & \multirow{2}{*}{$\begin{array}{l}\text { Length } \\
\text { of compu- } \\
\text { tational } \\
\text { element } \\
\text { (mile) }\end{array}$} & \multirow{2}{*}{$\begin{array}{l}\text { Discharge } \\
\text { coeffi- } \\
\text { cient for } \\
\text { velocity } \\
\left(c_{u}\right) \\
\left(\text { feet }^{-2}\right)\end{array}$} & \multirow{2}{*}{$\begin{array}{l}\text { Discharge } \\
\text { exponent } \\
\text { for } \\
\text { velocity } \\
\left(e_{u}\right)\end{array}$} & \multirow{2}{*}{$\begin{array}{l}\text { Discharge } \\
\text { coeffi- } \\
\text { cient for } \\
\text { depth } \\
\left(c_{h}\right) \\
\text { (seconds per } \\
\text { square foot) }\end{array}$} & \multirow{2}{*}{$\begin{array}{l}\text { Discharge } \\
\text { exponent } \\
\text { for } \\
\text { depth } \\
\left(e_{h}\right)\end{array}$} & \multirow{2}{*}{$\begin{array}{l}\text { Median } \\
\text { subreach } \\
\text { elevation } \\
\text { (feet) }\end{array}$} & \multirow{2}{*}{$\begin{array}{l}\text { Coeffi- } \\
\text { cient for } \\
\text { evap- } \\
\text { oration }\end{array}$} \\
\hline & $\begin{array}{l}\text { Up- } \\
\text { stream }\end{array}$ & $\begin{array}{l}\text { Down- } \\
\text { stream }\end{array}$ & & & & & & & \\
\hline
\end{tabular}

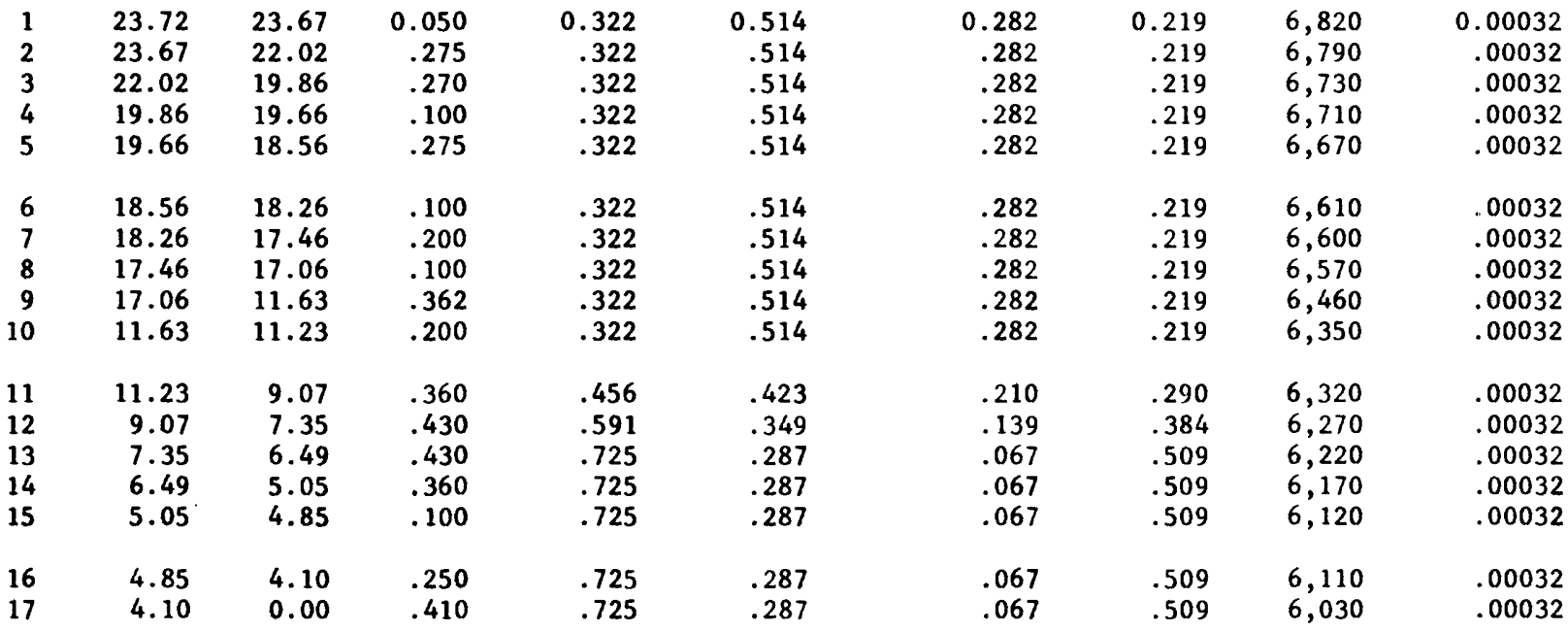

UPPER FOUNTAIN CREEK

\begin{tabular}{|c|c|c|c|c|c|c|c|c|c|}
\hline $\begin{array}{r}18 \\
19 \\
20 \\
21 \\
422\end{array}$ & $\begin{array}{l}68.15 \\
68.10 \\
68.05 \\
67.75 \\
67.27\end{array}$ & $\begin{array}{l}68.10 \\
68.05 \\
67.75 \\
67.27 \\
67.08\end{array}$ & $\begin{array}{r}0.050 \\
.050 \\
.100 \\
.160 \\
.190\end{array}$ & $\begin{array}{r}0.860 \\
.860 \\
.860 \\
.860 \\
.-\end{array}$ & $\begin{array}{c}0.206 \\
.206 \\
.206 \\
.206 \\
--\end{array}$ & $\begin{array}{c}0.161 \\
.161 \\
.161 \\
.161 \\
.-\end{array}$ & $\begin{array}{c}0.489 \\
.489 \\
.489 \\
.489 \\
.-\end{array}$ & $\begin{array}{l}8,150 \\
8,150 \\
8,130 \\
8,060 \\
8,010\end{array}$ & $\begin{array}{c}0.01400 \\
.01400 \\
.01400 \\
.01400 \\
.-\end{array}$ \\
\hline $\begin{array}{r}43 \\
24 \\
25 \\
26 \\
27\end{array}$ & $\begin{array}{l}67.08 \\
66.57 \\
66.52 \\
65.92 \\
64.58\end{array}$ & $\begin{array}{l}66.57 \\
66.52 \\
65.92 \\
64.58 \\
64.38\end{array}$ & $\begin{array}{l}.510 \\
.050 \\
.200 \\
.268 \\
.100\end{array}$ & $\begin{array}{l}-- \\
.860 \\
.860 \\
.860 \\
.860\end{array}$ & $\begin{array}{l}-. \\
.206 \\
.206 \\
.206 \\
.206\end{array}$ & $\begin{array}{l}.- \\
.161 \\
.161 \\
.161 \\
.161\end{array}$ & $\begin{array}{l}-- \\
.489 \\
.489 \\
.489 \\
.489\end{array}$ & $\begin{array}{l}7,950 \\
7,910 \\
7,890 \\
7,780 \\
7,680\end{array}$ & $\begin{array}{c}. \\
.01400 \\
.01400 \\
.01400 \\
.01400\end{array}$ \\
\hline $\begin{array}{l}28 \\
29 \\
30 \\
31 \\
32\end{array}$ & $\begin{array}{l}64.38 \\
60.74 \\
57.34 \\
56.46 \\
56.10\end{array}$ & $\begin{array}{l}60.74 \\
57.34 \\
56.46 \\
56.10 \\
53.85\end{array}$ & $\begin{array}{l}.364 \\
.425 \\
.440 \\
.180 \\
.375\end{array}$ & $\begin{array}{l}.860 \\
.860 \\
.860 \\
.860 \\
.860\end{array}$ & $\begin{array}{l}.206 \\
.206 \\
.206 \\
.206 \\
.206\end{array}$ & $\begin{array}{l}.161 \\
.161 \\
.161 \\
.161 \\
.210\end{array}$ & $\begin{array}{l}.489 \\
.489 \\
.489 \\
.489 \\
.338\end{array}$ & $\begin{array}{l}7,520 \\
6,930 \\
6,440 \\
6,370 \\
6,240\end{array}$ & $\begin{array}{l}.01400 \\
.01400 \\
.01400 \\
.01400 \\
.01400\end{array}$ \\
\hline $\begin{array}{l}33 \\
34 \\
35\end{array}$ & $\begin{array}{l}53.85 \\
52.95 \\
50.61\end{array}$ & $\begin{array}{l}52.95 \\
50.61 \\
49.34\end{array}$ & $\begin{array}{l}.450 \\
.390 \\
.420\end{array}$ & $\begin{array}{l}.860 \\
.860 \\
.860\end{array}$ & $\begin{array}{l}.206 \\
.206 \\
.206\end{array}$ & $\begin{array}{l}.258 \\
.307 \\
.307\end{array}$ & $\begin{array}{l}.233 \\
.161 \\
.161\end{array}$ & $\begin{array}{l}6,090 \\
6,010 \\
5,920\end{array}$ & $\begin{array}{l}.01400 \\
.00060 \\
.00032\end{array}$ \\
\hline
\end{tabular}


Table 4.--Physical data for subreaches in the summer stream reach--Continued

\begin{tabular}{|c|c|c|c|c|c|c|c|c|c|}
\hline \multirow{2}{*}{$\begin{array}{l}\text { Model } \\
\text { sub- } \\
\text { reach } \\
\text { number }\end{array}$} & \multicolumn{2}{|c|}{$\begin{array}{l}\text { River mile at } \\
\text { ends of subreach }\end{array}$} & \multirow{2}{*}{$\begin{array}{l}\text { Length } \\
\text { of compu- } \\
\text { tational } \\
\text { element } \\
\text { (mile) }\end{array}$} & \multirow{2}{*}{$\begin{array}{l}\text { Discharge } \\
\text { coeffi- } \\
\text { cient for } \\
\text { velocity } \\
\left(c_{u}\right) \\
\left(\text { feet }^{-2}\right)\end{array}$} & \multirow{2}{*}{$\begin{array}{l}\text { Discharge } \\
\text { exponent } \\
\text { for } \\
\text { velocity } \\
\left(e_{u}\right)\end{array}$} & \multirow{2}{*}{$\begin{array}{c}\text { Discharge } \\
\text { coeffi- } \\
\text { cient for } \\
\text { depth } \\
\left(c_{h}\right) \\
\text { (seconds per } \\
\text { square foot) }\end{array}$} & \multirow{2}{*}{$\begin{array}{c}\text { Discharge } \\
\text { exponent } \\
\text { for } \\
\text { depth } \\
\left(e_{h}\right)\end{array}$} & \multirow{2}{*}{$\begin{array}{l}\text { Median } \\
\text { subreach } \\
\text { elevation } \\
\text { (feet) }\end{array}$} & \multirow{2}{*}{$\begin{array}{l}\text { Coeffi- } \\
\text { cient for } \\
\text { evap- } \\
\text { oration }\end{array}$} \\
\hline & $\begin{array}{c}\text { Up- } \\
\text { stream }\end{array}$ & $\begin{array}{l}\text { Down- } \\
\text { stream }\end{array}$ & & & & & & & \\
\hline & \multicolumn{9}{|c|}{ MIDDLE FOUNTAIN CREEK } \\
\hline $\begin{array}{l}36 \\
37 \\
38 \\
39 \\
40\end{array}$ & $\begin{array}{l}49.34 \\
48.67 \\
48.42 \\
47.60 \\
45.62\end{array}$ & $\begin{array}{l}48.67 \\
48.42 \\
47.60 \\
45.62 \\
44.62\end{array}$ & $\begin{array}{r}0.340 \\
.050 \\
.164 \\
.220 \\
.200\end{array}$ & $\begin{array}{r}0.860 \\
.860 \\
.860 \\
.860 \\
.860\end{array}$ & $\begin{array}{r}0.206 \\
.206 \\
.206 \\
.206 \\
.206\end{array}$ & $\begin{array}{r}0.307 \\
.307 \\
.307 \\
.244 \\
.182\end{array}$ & $\begin{array}{r}0.161 \\
.161 \\
.161 \\
.206 \\
.264\end{array}$ & $\begin{array}{l}5,890 \\
5,870 \\
5,850 \\
5,830 \\
5,800\end{array}$ & $\begin{array}{r}0.00015 \\
.00015 \\
.00015 \\
.00015 \\
.00015\end{array}$ \\
\hline $\begin{array}{l}41 \\
42 \\
43 \\
44 \\
45\end{array}$ & $\begin{array}{l}44.62 \\
43.66 \\
40.99 \\
39.54 \\
39.44\end{array}$ & $\begin{array}{l}43.66 \\
40.99 \\
39.54 \\
39.44 \\
37.64\end{array}$ & $\begin{array}{l}.320 \\
.445 \\
.145 \\
.050 \\
.180\end{array}$ & $\begin{array}{l}.860 \\
.860 \\
.860 \\
.860 \\
.860\end{array}$ & $\begin{array}{l}.206 \\
.206 \\
.206 \\
.206 \\
.206\end{array}$ & $\begin{array}{l}.119 \\
.119 \\
.119 \\
.119 \\
.119\end{array}$ & $\begin{array}{l}.338 \\
.338 \\
.338 \\
.338 \\
.338\end{array}$ & $\begin{array}{l}5,760 \\
5,680 \\
5,620 \\
5,610 \\
5,580\end{array}$ & $\begin{array}{l}.00015 \\
.00015 \\
.00015 \\
.00015 \\
.00015\end{array}$ \\
\hline $\begin{array}{l}46 \\
47 \\
48 \\
49 \\
50\end{array}$ & $\begin{array}{l}37.64 \\
36.59 \\
36.07 \\
35.69 \\
34.28\end{array}$ & $\begin{array}{l}36.59 \\
36.07 \\
35.69 \\
34.28 \\
31.38\end{array}$ & $\begin{array}{l}.210 \\
.260 \\
.380 \\
.470 \\
.290\end{array}$ & $\begin{array}{l}.860 \\
.860 \\
.860 \\
.860 \\
.860\end{array}$ & $\begin{array}{l}.206 \\
.206 \\
.206 \\
.206 \\
.206\end{array}$ & $\begin{array}{l}.119 \\
.119 \\
.119 \\
.119 \\
.119\end{array}$ & $\begin{array}{l}.338 \\
.338 \\
.338 \\
.338 \\
.338\end{array}$ & $\begin{array}{l}5,540 \\
5,520 \\
5,510 \\
5,480 \\
5,430\end{array}$ & $\begin{array}{l}.00015 \\
.00015 \\
.00015 \\
.00015 \\
.00015\end{array}$ \\
\hline $\begin{array}{l}51 \\
52\end{array}$ & $\begin{array}{l}31.38 \\
29.79\end{array}$ & $\begin{array}{l}29.79 \\
29.47\end{array}$ & $\begin{array}{l}.265 \\
.320\end{array}$ & $\begin{array}{l}.860 \\
.860\end{array}$ & $\begin{array}{l}.206 \\
.206\end{array}$ & $\begin{array}{l}.119 \\
.119\end{array}$ & $\begin{array}{l}.338 \\
.338\end{array}$ & $\begin{array}{l}5,380 \\
5,340\end{array}$ & $\begin{array}{l}.00015 \\
.00015\end{array}$ \\
\hline
\end{tabular}

${ }^{1}$ Average stream transport velocity for each subreach $=c \times$ subreach discharge ${ }^{e}$.

${ }^{2}$ Average stream depth for each subreach $=c_{h} \times$ subreach $y_{i s c h a r g e} e$.

${ }^{3}$ Unit for evaporation coefficient is feet per hour $x$ inches of mercury $x$ miles per hour (See Brown and Barnwell, 1987, p. 67-68).

${ }^{4}$ Zero-discharge subreach. 
Table 5.--Physical data for subreaches in the winter stream reach

[River miles are measured upstream from the mouth of Fountain Creek]

\begin{tabular}{|c|c|c|c|c|c|c|c|c|c|}
\hline \multirow{2}{*}{$\begin{array}{l}\text { Mode1. } \\
\text { sub- } \\
\text { reach } \\
\text { number }\end{array}$} & \multicolumn{2}{|c|}{$\begin{array}{l}\text { River mile at } \\
\text { ends of subreach }\end{array}$} & \multirow{2}{*}{$\begin{array}{l}\text { Length } \\
\text { of compu- } \\
\text { tational } \\
\text { element } \\
\text { (mile) }\end{array}$} & \multirow{2}{*}{$\begin{array}{l}\text { Discharge } \\
\text { coeffi- } \\
\text { cient for } \\
\text { velocity } \\
\left(c_{u}\right) \\
\left(\text { feet }^{-2}\right)\end{array}$} & \multirow{2}{*}{$\begin{array}{l}\text { Discharge } \\
\text { exponent } \\
\text { for } \\
\text { velocity } \\
\left(e_{u}\right)\end{array}$} & \multirow{2}{*}{$\begin{array}{c}\text { Discharge } \\
\text { coeffi- } \\
\text { cient for } \\
\text { depth }{ }^{2} \\
\left(c_{h}\right) \\
\text { seconds per } \\
\text { square foot) }\end{array}$} & \multirow{2}{*}{$\begin{array}{c}\text { Discharge } \\
\text { exponent } \\
\text { for } \\
\text { depth } \\
\left(e_{h}\right)\end{array}$} & \multirow{2}{*}{$\begin{array}{l}\text { Median } \\
\text { subreach } \\
\text { elevation } \\
\text { (feet) }\end{array}$} & \multirow{2}{*}{$\begin{array}{l}\text { Coeffi- } \\
\text { cient for } \\
\text { evap- } \\
\text { oration }\end{array}$} \\
\hline & $\begin{array}{c}\text { Up- } \\
\text { stream }\end{array}$ & $\begin{array}{l}\text { Down- } \\
\text { stream }\end{array}$ & & & & & & & \\
\hline
\end{tabular}

MIDDLE FOUNTAIN CREEK

\begin{tabular}{|c|c|c|c|c|c|c|c|c|c|}
\hline $\begin{array}{l}35 a \\
36 \\
37 \\
38 \\
39\end{array}$ & $\begin{array}{l}49.39 \\
49.34 \\
48.67 \\
48.42 \\
47.60\end{array}$ & $\begin{array}{l}49.34 \\
48.67 \\
48.42 \\
47.60 \\
45.62\end{array}$ & $\begin{array}{r}0.050 \\
.340 \\
.050 \\
.164 \\
.220\end{array}$ & $\begin{array}{r}0.860 \\
.860 \\
.860 \\
.860 \\
.860\end{array}$ & $\begin{array}{r}0.206 \\
.206 \\
.206 \\
.206 \\
.206\end{array}$ & $\begin{array}{r}0.307 \\
.307 \\
.307 \\
.307 \\
.244\end{array}$ & $\begin{array}{r}0.161 \\
.161 \\
.161 \\
.161 \\
.206\end{array}$ & $\begin{array}{l}5,900 \\
5,890 \\
5,870 \\
5,850 \\
5,830\end{array}$ & $\begin{array}{r}0.00015 \\
.00015 \\
.00015 \\
.00015 \\
.00015\end{array}$ \\
\hline $\begin{array}{l}40 \\
41 \\
42 \\
43 \\
44\end{array}$ & $\begin{array}{l}45.62 \\
44.62 \\
43.66 \\
40.99 \\
39.54\end{array}$ & $\begin{array}{l}44.62 \\
43.66 \\
40.99 \\
39.54 \\
39.44\end{array}$ & $\begin{array}{l}.200 \\
.320 \\
.445 \\
.145 \\
.050\end{array}$ & $\begin{array}{l}.860 \\
.860 \\
.860 \\
.860 \\
.860\end{array}$ & $\begin{array}{l}.206 \\
.206 \\
.206 \\
.206 \\
.206\end{array}$ & $\begin{array}{l}.182 \\
.119 \\
.119 \\
.119 \\
.119\end{array}$ & $\begin{array}{l}.264 \\
.338 \\
.338 \\
.338 \\
.338\end{array}$ & $\begin{array}{l}5,800 \\
5,760 \\
5,680 \\
5,620 \\
5,610\end{array}$ & $\begin{array}{l}.00015 \\
.00015 \\
.00015 \\
.00015 \\
.00015\end{array}$ \\
\hline $\begin{array}{l}45 \\
46 \\
47 \\
48 \\
49\end{array}$ & $\begin{array}{l}39.44 \\
37.64 \\
36.59 \\
36.07 \\
35.69\end{array}$ & $\begin{array}{l}37.64 \\
36.59 \\
36.07 \\
35.69 \\
34.28\end{array}$ & $\begin{array}{l}.180 \\
.210 \\
.260 \\
.380 \\
.470\end{array}$ & $\begin{array}{l}.860 \\
.860 \\
.860 \\
.860 \\
.860\end{array}$ & $\begin{array}{l}.206 \\
.206 \\
.206 \\
.206 \\
.206\end{array}$ & $\begin{array}{l}.119 \\
.119 \\
.119 \\
.119 \\
.119\end{array}$ & $\begin{array}{r}.338 \\
.338 \\
.338 \\
.338 \\
.338\end{array}$ & $\begin{array}{l}5,580 \\
5,540 \\
5,520 \\
5,510 \\
5,480\end{array}$ & $\begin{array}{l}.00015 \\
.00015 \\
.00015 \\
.00015 \\
.00015\end{array}$ \\
\hline $\begin{array}{l}50 \\
51 \\
52 \\
53 \\
54\end{array}$ & $\begin{array}{l}34.28 \\
31.38 \\
29.79 \\
29.47 \\
29.23\end{array}$ & $\begin{array}{l}31.38 \\
29.79 \\
29.47 \\
29.23 \\
25.33\end{array}$ & $\begin{array}{l}.290 \\
.265 \\
.320 \\
.240 \\
.390\end{array}$ & $\begin{array}{l}.860 \\
.860 \\
.860 \\
.860 \\
.860\end{array}$ & $\begin{array}{l}.206 \\
.206 \\
.206 \\
.206 \\
.206\end{array}$ & $\begin{array}{l}.119 \\
.119 \\
.119 \\
.119 \\
.119\end{array}$ & $\begin{array}{l}.338 \\
.338 \\
.338 \\
.338 \\
.338\end{array}$ & $\begin{array}{l}5,430 \\
5,380 \\
5,340 \\
5,310 \\
5,280\end{array}$ & $\begin{array}{l}.00015 \\
.00015 \\
.00015 \\
.00015 \\
.00015\end{array}$ \\
\hline \multicolumn{10}{|c|}{ LOWER FOUNTAIN CREEK } \\
\hline $\begin{array}{l}55 \\
56 \\
57 \\
58 \\
59\end{array}$ & $\begin{array}{l}25.33 \\
25.15 \\
24.20 \\
24.00 \\
17.25\end{array}$ & $\begin{array}{l}25.15 \\
24.20 \\
24.00 \\
17.25 \\
14.25\end{array}$ & $\begin{array}{r}0.090 \\
.475 \\
.200 \\
.450 \\
.375\end{array}$ & $\begin{array}{r}0.860 \\
.860 \\
.860 \\
.860 \\
.860\end{array}$ & $\begin{array}{r}0.206 \\
.206 \\
.206 \\
.206 \\
.206\end{array}$ & $\begin{array}{r}0.119 \\
.119 \\
.119 \\
.119 \\
.119\end{array}$ & $\begin{array}{r}0.338 \\
.338 \\
.338 \\
.338 \\
.338\end{array}$ & $\begin{array}{l}5,250 \\
5,230 \\
5,220 \\
5,150 \\
5,030\end{array}$ & $\begin{array}{r}0.00015 \\
.00015 \\
.00015 \\
.00015 \\
.00015\end{array}$ \\
\hline $\begin{array}{l}60 \\
61 \\
62 \\
63 \\
64\end{array}$ & $\begin{array}{r}14.25 \\
13.75 \\
9.00 \\
8.60 \\
0.35\end{array}$ & $\begin{array}{r}13.75 \\
9.00 \\
8.60 \\
0.35 \\
0.00\end{array}$ & $\begin{array}{l}.250 \\
.475 \\
.200 \\
.550 \\
.350\end{array}$ & $\begin{array}{l}.860 \\
.860 \\
.860 \\
.860 \\
.860\end{array}$ & $\begin{array}{l}.206 \\
.206 \\
.206 \\
.206 \\
.206\end{array}$ & $\begin{array}{l}.119 \\
.119 \\
.119 \\
.119 \\
.119\end{array}$ & $\begin{array}{l}.338 \\
.338 \\
.338 \\
.338 \\
.338\end{array}$ & $\begin{array}{l}4,980 \\
4,920 \\
4,850 \\
4,750 \\
4,640\end{array}$ & $\begin{array}{l}.00015 \\
.00015 \\
.00015 \\
.00015 \\
.00015\end{array}$ \\
\hline
\end{tabular}

${ }^{1}$ Average stream transport velocity for each subreach $=c_{c} \times$ subreach discharge $e_{u}$.

${ }^{2}$ Average stream depth for each subreach $=c_{h} \times$ subreach discharge ${ }_{h}$.

3nit for evaporation coefficient is feet per hour $\times$ inches of mercury $\times$ miles per hour (See Brown and Barnwel1, 1987, p. 67-68). 
Traveltime measurements provide a velocity value between two points that integrates all of the physical variation between the two points, thus providing a more accurate stream transport-velocity value than that available from discharge measurements. The traveltime measurements made for this study were for a variety of discharges and for almost all of the summer and winter stream reaches. Therefore, the discharge coefficients and exponents needed for model input for solution of equation 1 could be derived for all the physical conditions along Monument and Fountain Creeks.

The discharge coefficients and exponents for computation of transport velocity were derived by using least-squares linear regression of the logarithms of the discharges that were measured at the time of the traveltime studies and the logarithms of the traveltimes for the various traveltime subreaches (Kuhn and Ortiz, 1989). Two coefficients and exponents for transport velocity were derived for Monument Creek for solution of equation 1. Only one coefficient and exponent for transport velocity were derived for Fountain Creek because the single regression equation was statistically better than two or three regression equations: The coefficients and exponents for computation of transport velocity and the model subreaches to which they apply are listed in tables 4 and 5 . The equations that were derived by the regression analysis are:

$$
\begin{aligned}
& \overline{\mathrm{U}}=0.332 Q^{0.514}, \text { and } \\
& \overline{\mathrm{U}}=0.725 \mathrm{Q}^{0.287}, \text { for Monument Creek; and } \\
& \overline{\mathrm{U}}=0.860 \mathrm{Q}^{0.206}, \text { for Fountain Creek. }
\end{aligned}
$$

For equations 3,4 , and 5 , coefficients of determination were $0.85,0.75$, and 0.76 , respectively; standard errors of estimate were +27 and $-21,+16$ and -13 , and +17 and -15 percent, respectively; and the number of data pairs used were 10,10 , and 58 , respectively.

Depth data for Monument and Fountain Creeks were not available from the traveltime measurements, but depth data were available from the measurements of channel geometry made during the reaeration measurements and during the diel-sampling periods. The coefficients and exponents for computation of depth (eq. 2) were derived by using least-squares linear regression of the logarithms of the discharges made in conjunction with the channel-geometry measurements and the logarithms of the average depth for each channel-geometry measurement.

Two coefficients and exponents for depth also were derived for Monument Creek for solution of equation 2. The equations are:

$$
\begin{aligned}
& \mathrm{H}=0.282 \mathrm{Q}^{0.219} \text { and } \\
& \mathrm{H}=0.067 \mathrm{Q}^{0.509} \text {. }
\end{aligned}
$$

For the two equations, coefficients of determination were 0.28 and 0.40 , respectively; standard errors of estimate were +39 and -28 , and +42 and -30 percent, respectively; and the number of data pairs used were 99 and 45, respectively.

Three coefficients and exponents for depth were derived for Fountain Creek for solution of equation 2. The equations are:

$$
\begin{aligned}
& H=0.161 Q^{0.489}, \\
& H=0.307 Q^{0.161}, \text { and } \\
& H=0.119 Q^{0.338} .
\end{aligned}
$$


For the three equations, coefficients of determination were $0.78,0.23$, and 0.31 , respectively; standard errors of estimate were +50 and $-33,+32$ and -25 , and +27 and -21 percent, respectively; and the number of data pairs used were 79,75 , and 330 , respectively.

Although equations $6,7,9$, and 10 had small coefficients of determination, the equations were used because the regressions were significant at the 95-percent confidence level and because stream depth is considerably variable in Monument and Fountain Creeks. The coefficients and exponents for computation of average depth and the subreaches to which they apply are listed in tables 4 and 5 .

Weighted-average coefficients and exponents for velocity and depth (tables 4 and 5) were calculated for the two adjacent subreaches on Monument Creek or Fountain Creek (subreaches 11 and 12, 31 and 32 , and 39 and 40) when changing from one regression equation to another. The weighted-average coefficients were calculated by using a two-to-one weighting for each of the two adjacent subreaches. The same weighting was used for the exponents, but in this instance the logarithms of the exponents were weighted. The coefficients and exponents were weighted because the physical changes in Monument and Fountain Creeks are not abrupt; thus, the weighting will decrease abrupt, un-natural changes in the model results. Finally, the selection of the stream sections for which the different regression equations for transport velocity and depth were derived was based on changes in the physical characteristics of the streams and on the changes in the measured reaeration coefficients.

\section{Reaeration Data}

Three methods to compute stream reaeration are available in the QUAL2E model: (1) Reaeration can be computed as a power function of discharge (identical to the computation of transport velocity or depth with equations 1 or 2); (2) reaeration can be computed on the basis of measured reaeration coefficients specified in the input data; and (3) reaeration can be computed on the basis of six different estimating equations (Brown and Barnwell, 1987, p. 42-48). The third method was selected for use in the analysis described in this report.

Numerous equations have been developed to estimate reaeration; these equations usually are classified as empirical or semi-empirical. Empirical equations are based on velocity-depth relations, whereas semi-empirical

equations are based on energy dissipation. Bowie and others (1985, p. 101-115) present a brief summary of reaeration theory and the different estimating equations; Rathbun (1977) presents more complete descriptions of the equations.

Selection of the reaeration estimating equations for calibrating and verifying the model was made on the basis of comparing measured reaeration coefficients to estimated reaeration coefficients. Twenty-six measured reaeration coefficients (table 6 ) were used in the comparison. The value of the measured reaeration coefficients generally varied with changes in the physical characteristics of Monument and Fountain Creeks; these changes were used, in part, to define the stream sections used in deriving the coefficients and exponents to estimate transport velocity and depth (tables 4 and 5). The same stream sections, therefore, were used in the comparisons of measured and estimated reaeration coefficients. 
Table 6.--Measured reaeration coefficients for selected stream reaches on Monument Creek and Fountain Creek

[River miles are measured upstream from the mouth of Monument Creek or Fountain Creek. ${ }^{\circ} \mathrm{C}$, degrees Celsius; model subreaches listed in tables 4 and $5 ; \cdots$, no data]

\begin{tabular}{|c|c|c|c|c|c|}
\hline \multicolumn{2}{|c|}{$\begin{array}{l}\text { River mile of } \\
\text { reaeration } \\
\text { stream reach }\end{array}$} & \multicolumn{3}{|c|}{$\begin{array}{l}\text { Reaeration coefficients } \\
\text { (base e units at } 20^{\circ} \mathrm{C} \text {, in days }{ }^{-1} \text { ) }\end{array}$} & \multirow{3}{*}{$\begin{array}{l}\text { Model } \\
\text { subreaches } \\
\text { to which } \\
\text { coefficient } \\
\text { applies }\end{array}$} \\
\hline \multirow{2}{*}{$\begin{array}{c}\text { Up- } \\
\text { stream }\end{array}$} & \multirow{2}{*}{$\begin{array}{l}\text { Down- } \\
\text { stream }\end{array}$} & Peak method & \multicolumn{2}{|c|}{ Area method } & \\
\hline & & Ethylene Propane & Ethylene & Propane & \\
\hline
\end{tabular}

MONUMENT CREEK

$\begin{array}{rrrrrrr}17.46 & 17.21 & 17.6 & -- & 22.8 & -- & 1 \text { to } 11 \\ 9.91 & 8.68 & 93.1 & -- & 75.7 & -- & 12 \text { to } 17\end{array}$

\section{FOUNTAIN CREEK}

\begin{tabular}{|c|c|c|c|c|c|c|c|}
\hline 64.58 & 63.98 & - & 154 & -- & 184 & 18 & to 32 \\
\hline 59.30 & 59.15 & -- & - & -- & 186 & 18 & to 32 \\
\hline 55.00 & 54.61 & 195 & -- & 197 & 178 & 18 & to 32 \\
\hline 54.61 & 53.84 & 97.2 & -- & 105 & -- & 33 & to 39 \\
\hline 46.95 & 45.22 & -- & 52.8 & -- & -- & 33 & to 39 \\
\hline 38.60 & 37.43 & - & 32.7 & -- & -- & 40 & to 64 \\
\hline 37.43 & 35.85 & - & 28.9 & - & -- & 40 & to 64 \\
\hline 35.85 & 34.88 & -- & 27.2 & - & -- & 40 & to 64 \\
\hline 25.25 & 24.00 & -- & 48.6 & - & -- & 40 & to 64 \\
\hline 24.00 & 23.00 & -- & 24.2 & -- & -- & 40 & to 64 \\
\hline 15.00 & 14.00 & -- & 23.0 & -- & -- & 40 & to 64 \\
\hline 14.00 & 12.55 & -- & 34.1 & - & - & 40 & to 64 \\
\hline 12.55 & 10.90 & -- & 23.6 & - & -- & 40 & to 64 \\
\hline 4.50 & 4.00 & 29.4 & 38.5 & - & -- & 40 & to 64 \\
\hline 4.00 & 2.60 & 43.2 & 48.2 & -- & -- & 40 & to 64 \\
\hline 2.60 & 0.00 & 50.8 & -- & - & -- & 40 & to 64 \\
\hline
\end{tabular}

${ }^{1}$ Methods of computation described in Kilpatrick and others (1989). 
The measured coefficients were grouped by stream section. The 19 reaeration equations described by Rathbun (1977) were used to compute an estimated reaeration coefficient for each measured coefficient in each stream section. The average estimation error for each reaeration equation then was computed for each stream section. Results of the average estimation-error computation are listed in table 7; the literature reference for only the five reaeration estimating equations with the smallest average estimation error are listed.

The reaeration estimating equation with the smallest average estimation error for each of the five stream sections (table 7) was selected for calibrating and verifying the model. The four equations that were selected and the model subreaches to which each equation applies are listed in table 8 . The reaeration estimating equations were used in calibrating and verifying the model instead of direct use of the measured reaeration coefficients because: (1) Reaeration generally changes with changes in velocity and depth, and hence, discharge (Bowie and others, 1985, p. 101-115); (2) stream discharge during the reaeration measurements was not necessarily the same as during the diel-sampling periods; and (3) measured reaeration coefficients were not available for all model subreaches, especially for Monument Creek and upper Fountain Creek. Additional reaeration measurements could not be made for these two stream sections because (1) suitable gas-injection sites were not available because of shallow depths, or (2) the injected gases were rapidly desorbed because of turbulent flow. Equation 3 (table 8) was initially used for subreaches 18-32 (table 7). However, the simulated DO for subreaches 18-26 did not compare reasonably to the measured D0; therefore, equation 1 (table 8) was used for subreaches 18-26 because this equation provided more accurate simulation of DO for these subreaches. The QUAL2E model did not have the capability to use three of the reaeration estimating equations (table 8 , eqs. 1,3 , and 4 ), so this capability was added to the model.

\section{Preparation of Water-Quality Data for Model Input}

Water-quality data are needed for model input for each constituent to be modeled, which, in this study, are organic nitrogen, ammonia, nitrite, nitrate, 5-day CBOD, and DO. These data are needed for Monument and Fountain Creeks at the beginning of a stream reach, for each tributary, for each wastewater outfall, and for any simulated ground-water discharge. For convenience, preparation of stream-temperature data for model input is included in this section of the report. 
Table 7.--Comparison of estimation errors for selected

literature reaeration estimating equations for

Monument Creek and Fountain Creek

[Types of reaeration estimating equations are: E, empirical (velocity-depth equations) and S, semi-empirical (energy-dissipation equations). Measured reaeration coefficients used in the analysis are listed in table 6 . Model subreaches are listed in tables 4 and 5 ]

Literature reference

for reaeration estimating equation

\begin{tabular}{ccc}
$\operatorname{Type}_{\text {of }}$ & $\begin{array}{c}\text { Error of estimated reaeration } \\
\text { coefficient (percent) }\end{array}$ \\
\cline { 2 - 3 } equation & Range & Average $\begin{array}{l}\text { Standard } \\
\text { deviation }\end{array}$
\end{tabular}

Number of measured reaeration coefficients used in analysis

MONUMENT CREEK--MODEL SUBREACHES 1 TO 11

Negulescu and Rojanski (1969) ${ }^{2}$ Langbein and Durum (1967)

Parkhurst and Pomeroy (1972)

Isaacs and Gaudy (1968)

Padden and Gloyna (1971)

$\begin{array}{lllr}\mathrm{E} & -16.2 & \text { to } & 8.58 \\ \mathrm{E} & -18.9 & \text { to } & 5.07 \\ \mathrm{~S} & -22.8 & \text { to } & .05 \\ \mathrm{E} & 3.52 & \text { to } & 34.1 \\ \mathrm{E} & -38.9 & \text { to } & -20.8\end{array}$

MONUMENT CREEK--MODEL SUBREACHES 12 TO 17
Churchill and others $(1962)^{2}$

Tsivoglou and Neal (1976)

Krenkel and Orlob (1963)

0 'Connor and Dobbins (1958)

Isaacs and Gaudy (1968)

$\begin{array}{lllll}E & -11.4 & \text { to } & 8.93 & -1.25 \\ \mathrm{~S} & -13.2 & \text { to } & 6.70 & -3.27 \\ \mathrm{~S} & .51 \text { to } & 23.6 & 12.1 \\ \mathrm{E} & -25.5 & \text { to } & -8.35 & -16.9 \\ \mathrm{E} & -44.6 & \text { to } & -31.9 & -38.3\end{array}$

17.5

16.9

16.1

21.6

12.8
14.4

14.1

16.3

12.1

9.00

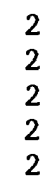

FOUNTAIN CREEK--MODEL SUBREACHES 18 TO 32

\begin{tabular}{|c|c|c|c|c|c|c|}
\hline Owens and others $(1964 \text {, eq. } 1)^{2}$ & $\mathbf{E}$ & -34.8 & to & 14.6 & -16.1 & 19.6 \\
\hline Owens and others (1964, eq. 2) & E & -34.9 & to & 14.4 & -16.2 & 19.6 \\
\hline Bennett and Rathbun (1972) & $\mathrm{S}$ & -34.4 & to & 15.3 & -18.6 & 22.6 \\
\hline Cadwallader and McDonnell (1969) & $\mathbf{S}$ & -49.2 & to & 28.8 & -26.4 & 30.0 \\
\hline Bennett and Rathbun (1972) & $\mathrm{E}$ & -48.1 & to & -11.4 & -34.3 & 14.4 \\
\hline
\end{tabular}

FOUNTAIN CREEK--MODEL SUBREACHES 33 TO 39

\begin{tabular}{|c|c|c|c|c|c|c|}
\hline Bennett and Rathbun $(1972)^{2}$ & E & -7.32 & to & 0.12 & -3.87 & 3.75 \\
\hline Krenkel and Orlob (1963) & $\mathbf{S}$ & -17.6 & to & 5.26 & -7.74 & 11.7 \\
\hline Cadwallader and McDonnell (1969) & $\mathbf{S}$ & 10.5 & to & 19.4 & 14.3 & 4.59 \\
\hline Owens and others (1964, eq. 2) & E & 12.6 & to & 25.1 & 17.8 & 6.49 \\
\hline Bennett and Rathbun (1972) & $\mathbf{S}$ & 5.08 & to & 29.5 & 18.1 & 12.3 \\
\hline
\end{tabular}

FOUNTAIN CREEK--MODEL SUBREACHES 40 TO 64

\begin{tabular}{|c|c|c|c|c|c|c|}
\hline Negulescu and Rojanski $(1969)^{2}$ & $\mathrm{E}$ & -33.2 & 73.2 & 8.67 & 34.0 & 13 \\
\hline Langbein and Durum (1967) & $\mathbf{E}$ & -37.3 & 78.4 & 9.26 & 37.6 & 13 \\
\hline $0^{\prime}$ Connor and Dobbins (1958) & $\mathbf{E}$ & -29.4 & to 114 & 29.8 & 47.8 & 13 \\
\hline Padden and Gloyna (1971) & $\mathbf{E}$ & -60.9 & 2.60 & -33.9 & 21.4 & 13 \\
\hline Isaacs and Gaudy (1968) & $\mathrm{E}$ & -24.8 & to 119 & 34.6 & 48.0 & 13 \\
\hline
\end{tabular}

${ }^{1}$ Error computed as: $\frac{\text { Estimated reaeration coefficient - measured reaeration coefficient }}{\text { Measured reaeration coefficient }} 100$

${ }^{2}$ Equation selected for use in modeling analysis and listed in table 8 . 
Table 8.--Reaeration estimating equations and model subreaches for which equations are used to estimate stream reaeration

[Model subreaches listed in tables 4 and $5 . K_{2}$, reaeration coefficient, base e units at 20 degrees Celsius, in days ${ }^{-1}$; $\overline{\mathrm{U}}$, average stream transport velocity, in feet per second; $H$, average stream depth, in feet]

\begin{abstract}
Reaeration estimating equation number and reference
\end{abstract}

\author{
Reaeration \\ estimating \\ equation
}

Model subreaches for which equation is used

1. Negulescu and Rojanski (1969)

$$
K_{2}=10.91 \frac{\overline{\mathrm{U}}}{\mathrm{H}}^{0.85}
$$

$1-11,18-26,40-64$

2. Churchill and
others (1962)

$$
\mathrm{K}_{2}=\frac{11.57 \overline{\mathrm{U}}^{0.969}}{\mathrm{H}^{1.673}}
$$

3. Owens and others (1964, eq. 1)

$$
K_{2}=\frac{23.23 \bar{U}^{0.73}}{H^{1.75}}
$$

4. Bennett and

Rathbun (1972)

$$
K_{2}=\frac{20.17 \bar{U}^{0.607}}{H^{1.689}}
$$

\section{Surface Water}

For sites at the beginning of a stream reach, for tributary sites, and for wastewater-outfall sites, the water-quality input data consists of averages of the water-quality data obtained during the four diel-sampling periods (Kuhn and Ortiz, 1989); the averages of these data are listed in tables 9 and 10 . In addition, for calibration and verification, water-quality data also are needed for sites on Monument and Fountain Creeks (table 1) to provide a check of the simulated concentrations of each water-quality constituent. These data are indicated by the maximum, average, and minimum measured concentration for each water-quality constituent in the figures that show the model calibration and verification results. 
Table 9.--Averages of water-quality data used for calibrating and

verifying the summer stream reach

$\left[\mathrm{ft}^{3} / \mathrm{s}\right.$, cubic foot per second; ${ }^{\circ} \mathrm{C}$, degrees Celsius; mg/L, milligrams per liter; CAL, calibration; VER, verification; --, not applicable]

\begin{tabular}{|c|c|c|c|c|c|c|c|c|c|}
\hline $\begin{array}{l}\text { Sampling- } \\
\text { site } \\
\text { number } \\
\text { (tables } \\
2 \text { and } 3 \text { ) }\end{array}$ & $\begin{array}{l}\text { Simu- } \\
\text { lation }\end{array}$ & $\begin{array}{c}\text { Discharge } \\
\left(\mathrm{ft}^{3} / \mathrm{s}\right)\end{array}$ & $\begin{array}{l}\text { Stream } \\
\text { temper- } \\
\text { ature } \\
(\because \mathrm{C})\end{array}$ & $\begin{array}{c}\text { Total } \\
\text { organic } \\
\text { nitrogen } \\
(\mathrm{mg} / \mathrm{L})\end{array}$ & $\begin{array}{l}\text { Total } \\
\text { ammonia } \\
\text { as ni- } \\
\text { trogen } \\
\text { (mg/L) }\end{array}$ & $\begin{array}{l}\text { Total } \\
\text { nitrite } \\
\text { as ni- } \\
\text { trogen } \\
(\mathrm{mg} / \mathrm{L})\end{array}$ & $\begin{array}{l}\text { Total } \\
\text { nitrate } \\
\text { as ni- } \\
\text { trogen } \\
(\mathrm{mg} / \mathrm{L})\end{array}$ & $\begin{array}{c}\text { 5-day } \\
\text { carbona- } \\
\text { ceous bio- } \\
\text { chemical } \\
\text { oxygen } \\
\text { demand } \\
(\mathrm{mg} / \mathrm{L})\end{array}$ & $\begin{array}{l}\text { Dis- } \\
\text { solved } \\
\text { oxygen } \\
\text { (mg/L) }\end{array}$ \\
\hline$M 23.68$ & $\begin{array}{l}\text { CAL } \\
\text { VER }\end{array}$ & $\begin{array}{l}8.74 \\
2.14\end{array}$ & $\begin{array}{l}18.7 \\
21.8\end{array}$ & $\begin{array}{r}0.53 \\
.43\end{array}$ & $\begin{array}{r}0.07 \\
.14\end{array}$ & $\begin{array}{r}0.01 \\
.02\end{array}$ & $\begin{array}{r}0.05 \\
.09\end{array}$ & 0.7 & $\begin{array}{l}7.4 \\
6.8\end{array}$ \\
\hline \multirow[t]{2}{*}{ MT23.67 } & CAL & 1.25 & 20.4 & 8.37 & 16.4 & .32 & .19 & $\begin{array}{r}1.2 \\
19.6\end{array}$ & $\begin{array}{l}0.8 \\
6.8\end{array}$ \\
\hline & VER & .52 & 20.5 & 14.6 & .42 & 9.20 & 1.90 & 26.1 & 5.3 \\
\hline \multirow[t]{2}{*}{ MT21.21 } & CAL & .25 & 16.8 & .49 & .01 & .01 & .05 & .8 & 6.8 \\
\hline & VER & 1.60 & 23.4 & .26 & .04 & .01 & .05 & .1 & 7.0 \\
\hline \multirow[t]{2}{*}{ MT 19.76} & CAL & .15 & 16.8 & .76 & .04 & .01 & .05 & .8 & 5.3 \\
\hline & VER & .05 & 20.5 & 1.20 & .05 & .01 & .05 & .8 & 7.8 \\
\hline \multirow[t]{2}{*}{${ }^{2}$ MT 19.66} & CAL & 0 & -- & -- & -- & -- & -- & -- & -- \\
\hline & VER & 0 & -- & -- & -- & -- & -- & -- & -- \\
\hline \multirow[t]{2}{*}{ MT 19.17} & CAL & .07 & 16.3 & .59 & .01 & .01 & .05 & .1 & 6.6 \\
\hline & VER & .04 & 15.1 & .91 & .19 & .01 & .05 & .9 & 5.0 \\
\hline \multirow[t]{2}{*}{ MT 18. 37} & CAL & 0 & -- & -- & -- & -- & -- & -- & -- \\
\hline & VER & .05 & 17.0 & .85 & .03 & .01 & .19 & .8 & 6.8 \\
\hline \multirow[t]{2}{*}{ MT17.45 } & CAL & .40 & 16.7 & .93 & .03 & .01 & .68 & .6 & 6.5 \\
\hline & VER & .11 & 18.3 & .54 & .06 & .02 & .75 & 1.6 & 6.4 \\
\hline \multirow[t]{2}{*}{ MT17.16 } & CAL & .79 & 16.4 & .43 & .02 & .01 & .36 & .3 & 6.4 \\
\hline & VER & .77 & 17.7 & .89 & .11 & .19 & .10 & .4 & 7.0 \\
\hline \multirow[t]{2}{*}{ MT14.89 } & CAL & 1.60 & 19.5 & .84 & .06 & .03 & .05 & .3 & 6.4 \\
\hline & VER & .12 & 21.0 & .44 & .06 & .01 & .05 & .4 & 6.8 \\
\hline \multirow[t]{2}{*}{${ }^{2} \mathrm{MT} 13.43$} & CAL & 0 & -- & -- & -- & -- & -- & -- & -- \\
\hline & VER & 0 & -- & -- & -- & -- & - & -- & -- \\
\hline \multirow[t]{2}{*}{ MT11.42 } & CAL & .03 & 17.3 & .73 & .03 & .01 & .05 & .2 & 5.8 \\
\hline & VER & 0 & -- & -- & -- & - & -- & -- & -- \\
\hline \multirow[t]{2}{*}{ MT 10.52} & CAL & 1.47 & 18.2 & .75 & .05 & .01 & .49 & .2 & 6.3 \\
\hline & VER & .43 & 16.6 & .35 & .05 & .01 & 1.69 & .1 & 7.3 \\
\hline \multirow[t]{2}{*}{ MT9.06 } & CAI & 1.49 & 18.9 & 1.10 & .02 & .03 & 3.87 & .6 & 6.6 \\
\hline & VER & 1.02 & 21.0 & .54 & .06 & .03 & 3.17 & .6 & 6.8 \\
\hline \multirow[t]{2}{*}{ MT8. 18} & CAL & 5.10 & 20.0 & .89 & .01 & .03 & 3.82 & .2 & 6.0 \\
\hline & VER & 3.60 & 22.2 & .54 & .06 & .04 & 3.46 & .1 & 5.9 \\
\hline \multirow[t]{2}{*}{${ }^{3} \mathrm{MT} 6.13$} & CAL & 3.71 & -- & -- & -- & -- & -- & -- & -- \\
\hline & VER & 0 & -- & -- & -- & -- & -- & -- & -- \\
\hline \multirow[t]{2}{*}{ MT4.95 } & CAL & .45 & 24.5 & 2.20 & .13 & .33 & 13.7 & 1.8 & 6.0 \\
\hline & VER & .23 & 25.8 & 1.20 & .08 & .38 & 9.12 & 2.3 & 7.2 \\
\hline \multirow[t]{2}{*}{ MT4.88 } & CAL & .46 & 21.1 & .88 & .07 & .04 & .86 & 1.7 & 8.4 \\
\hline & VER & 0 & -- & -- & -- & -- & -- & -- & -- \\
\hline \multirow[t]{2}{*}{ MT4.36 } & CAL & .34 & 16.9 & .29 & .01 & .01 & 3.90 & .1 & 10.1 \\
\hline & VER & 0 & - & -- & -- & -- & -- & -- & -- \\
\hline \multirow[t]{2}{*}{ FT68. 10} & CAL & .31 & 18.2 & 19.1 & 16.4 & 1.35 & .14 & 35.0 & 5.3 \\
\hline & VER & .16 & 18.5 & 10.4 & 28.9 & .10 & .25 & 28.4 & 6.0 \\
\hline FT68.09 & CAL & .02 & 17.4 & 22.5 & 3.77 & 1.14 & 11.8 & 20.0 & 2.8 \\
\hline & VER & .02 & 17.5 & 37.0 & 5.50 & .22 & 21.8 & .9 & 3.6 \\
\hline FT67.75 & CAL & .02 & 15.8 & 2.00 & .05 & .01 & .18 & 3.1 & 5.6 \\
\hline & VER & .02 & 15.9 & .86 & .09 & .02 & .18 & .8 & 5.7 \\
\hline F66.52 & CAL & .08 & 13.5 & .95 & .29 & .04 & 3.37 & 1.3 & 4.7 \\
\hline & VER & .18 & 10.8 & .51 & .12 & .01 & 3.11 & .3 & 6.3 \\
\hline FT66.51 & CAL & .29 & 13.3 & .36 & .03 & .01 & .65 & .2 & 6.5 \\
\hline & VER & .14 & 13.3 & .30 & .05 & .02 & 1.28 & .3 & 6.0 \\
\hline
\end{tabular}


Table 9.--Averages of water-quality data used for calibrating and verifying the summer stream reach--Continued

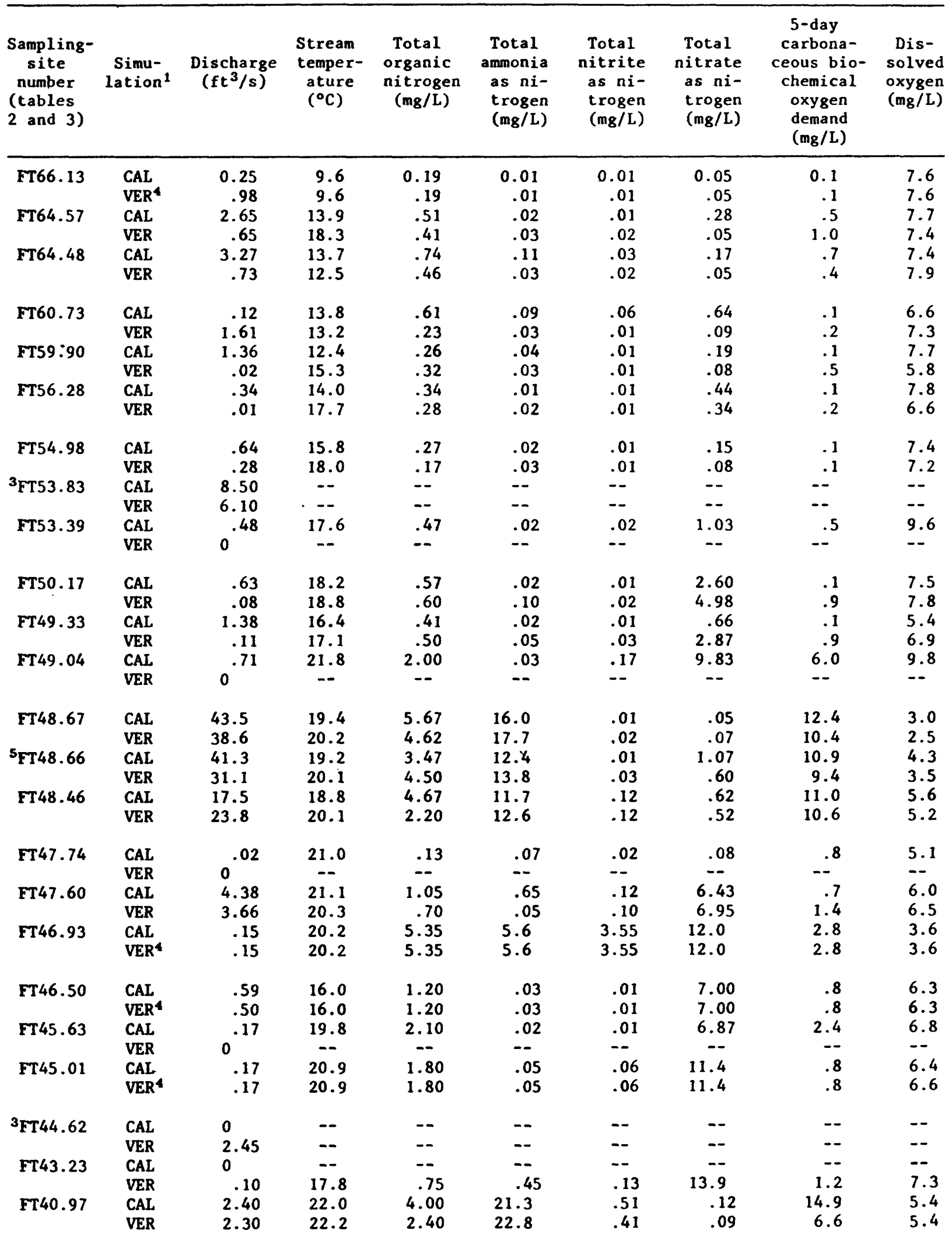


Table 9.--Averages of water-quality data used for calibrating and verifying the sumer stream reach--Continued

\begin{tabular}{|c|c|c|c|c|c|c|c|c|c|}
\hline $\begin{array}{l}\text { Sampling- } \\
\text { site } \\
\text { number } \\
\text { (tables } \\
2 \text { and } 3 \text { ) }\end{array}$ & $\begin{array}{l}\text { Simu- } \\
\text { lation } 1\end{array}$ & $\begin{array}{c}\text { Discharge } \\
\left(\mathrm{ft}^{3} / \mathrm{s}\right)\end{array}$ & $\begin{array}{l}\text { Stream } \\
\text { temper- } \\
\text { ature } \\
\left({ }^{\circ} \mathrm{C}\right)\end{array}$ & $\begin{array}{c}\text { Total } \\
\text { organic } \\
\text { nitrogen } \\
(\mathrm{mg} / \mathrm{L})\end{array}$ & $\begin{array}{c}\text { Total } \\
\text { ammonia } \\
\text { as ni- } \\
\text { trogen } \\
(\mathrm{mg} / \mathrm{L})\end{array}$ & $\begin{array}{c}\text { Total } \\
\text { nitrite } \\
\text { as ni- } \\
\text { trogen } \\
(\mathrm{mg} / \mathrm{L})\end{array}$ & $\begin{array}{c}\text { Total } \\
\text { nitrate } \\
\text { as ni- } \\
\text { trogen } \\
(\mathrm{mg} / \mathrm{L})\end{array}$ & $\begin{array}{c}\text { 5-day } \\
\text { carbona- } \\
\text { ceous bio- } \\
\text { chemical } \\
\text { oxygen } \\
\text { demand } \\
(\mathrm{mg} / \mathrm{L})\end{array}$ & $\begin{array}{l}\text { Dis- } \\
\text { solved } \\
\text { oxygen } \\
(\mathrm{mg} / \mathrm{L})\end{array}$ \\
\hline FT39.97 & $\begin{array}{l}\text { CAL } \\
\text { VER }\end{array}$ & $\begin{array}{r}0.33 \\
.33\end{array}$ & $\begin{array}{l}21.3 \\
21.3\end{array}$ & $\begin{array}{l}1.19 \\
1.19\end{array}$ & $\begin{array}{r}0.01 \\
.01\end{array}$ & $\begin{array}{r}0.05 \\
.05\end{array}$ & $\begin{array}{l}6.15 \\
6.15\end{array}$ & $\begin{array}{l}2.7 \\
2.7\end{array}$ & $\begin{array}{l}9.5 \\
9.5\end{array}$ \\
\hline FT39.53 & $\begin{array}{l}\text { CAL } \\
\text { VER }\end{array}$ & $\begin{array}{l}2.00 \\
2.07\end{array}$ & $\begin{array}{l}20.6 \\
21.1\end{array}$ & $\begin{array}{l}3.21 \\
1.83\end{array}$ & $\begin{array}{l}2.96 \\
16.0\end{array}$ & $\begin{array}{r}1.23 \\
.14\end{array}$ & $\begin{array}{r}1.31 \\
.09\end{array}$ & $\begin{array}{l}6.3 \\
5.3\end{array}$ & $\begin{array}{l}5.2 \\
4.0\end{array}$ \\
\hline FT39.52 & $\begin{array}{l}\text { CAL } \\
\text { VER }\end{array}$ & $\begin{array}{l}4.30 \\
4.70\end{array}$ & $\begin{array}{l}21.5 \\
22.4\end{array}$ & $\begin{array}{l}2.51 \\
1.40\end{array}$ & $\begin{array}{l}4.36 \\
4.28\end{array}$ & $\begin{array}{l}1.19 \\
1.00\end{array}$ & $\begin{array}{l}5.21 \\
5.00\end{array}$ & $\begin{array}{l}6.6 \\
6.3\end{array}$ & $\begin{array}{l}5.8 \\
5.1\end{array}$ \\
\hline${ }^{3}$ FT39.08 & $\begin{array}{l}\text { CAL } \\
\text { VER }\end{array}$ & $\begin{array}{l}38.0 \\
6.62\end{array}$ & -- & -- & -- & -- & -- & -- & -- \\
\hline FT38.52 & $\begin{array}{l}\text { CAL } \\
\text { VER }\end{array}$ & $\begin{array}{l}0 \\
0\end{array}$ & -- & -- & -- & -- & -- & -- & -- \\
\hline FT36.33 & $\begin{array}{l}\text { CAL } \\
\text { VER }\end{array}$ & $\begin{array}{l}.30 \\
.56\end{array}$ & $\begin{array}{l}18.6 \\
19.3\end{array}$ & $\begin{array}{l}.29 \\
.28\end{array}$ & $\begin{array}{l}.01 \\
.02\end{array}$ & $\begin{array}{l}.01 \\
.01\end{array}$ & $\begin{array}{l}.05 \\
.07\end{array}$ & $\begin{array}{l}.4 \\
.7\end{array}$ & $\begin{array}{l}5.8 \\
7.5\end{array}$ \\
\hline${ }^{3}$ FT35.69 & $\begin{array}{l}\text { CAL } \\
\text { VER }\end{array}$ & $\begin{array}{l}0 \\
473\end{array}$ & -- & -- & -- & -- & -- & -- & -- \\
\hline FT35. 20 & $\begin{array}{l}\text { CAL } \\
\text { VER }\end{array}$ & $\begin{array}{l}.46 \\
.70\end{array}$ & $\begin{array}{l}15.4 \\
20.0\end{array}$ & $\begin{array}{l}.42 \\
.50\end{array}$ & $\begin{array}{l}.03 \\
.10\end{array}$ & $\begin{array}{l}.02 \\
.03\end{array}$ & $\begin{array}{l}1.68 \\
2.07\end{array}$ & $\begin{array}{r}.2 \\
1.1\end{array}$ & $\begin{array}{l}4.2 \\
7.1\end{array}$ \\
\hline FT34.26 & $\begin{array}{l}\text { CAL } \\
\text { VER }\end{array}$ & $\begin{array}{l}.76 \\
.77\end{array}$ & $\begin{array}{l}23.0 \\
21.8\end{array}$ & $\begin{array}{l}15.0 \\
8.65\end{array}$ & $\begin{array}{r}2.50 \\
.89\end{array}$ & $\begin{array}{r}.52 \\
1.15\end{array}$ & $\begin{array}{l}.03 \\
.25\end{array}$ & $\begin{array}{l}14.8 \\
11.2\end{array}$ & $\begin{array}{l}3.8 \\
2.8\end{array}$ \\
\hline${ }^{3} \mathrm{FT} 33.70$ & $\begin{array}{l}\text { CAL } \\
\text { VER }\end{array}$ & $\begin{array}{l}0 \\
6.62\end{array}$ & -- & -- & -- & -- & -- & -- & -- \\
\hline${ }^{3}$ FT33. 12 & $\begin{array}{l}\text { CAL } \\
\text { VER }\end{array}$ & $\begin{array}{c}13.8 \\
0\end{array}$ & -- & -- & -- & -- & -- & -- & -- \\
\hline FT30. 32 & $\begin{array}{l}\text { CAL } \\
\text { VER }\end{array}$ & $\begin{array}{l}.73 \\
.11\end{array}$ & $\begin{array}{l}22.7 \\
26.4\end{array}$ & $\begin{array}{l}.63 \\
.33\end{array}$ & $\begin{array}{l}.05 \\
.07\end{array}$ & $\begin{array}{l}.01 \\
.01\end{array}$ & $\begin{array}{l}.61 \\
.07\end{array}$ & $\begin{array}{r}.2 \\
1.0\end{array}$ & $\begin{array}{l}6.4 \\
6.0\end{array}$ \\
\hline${ }^{3} \mathrm{FT} 30.06$ & $\begin{array}{l}\text { CAL } \\
\text { VER }\end{array}$ & $\begin{array}{l}3.10 \\
2.13\end{array}$ & -- & -- & -- & -- & -. & -- & -- \\
\hline
\end{tabular}

${ }^{1}$ Date for calibration data set is July 20-21, 1987; date for verification data set is July $15-16,1986$.

${ }^{2}$ No discharge at site during sampling periods.

${ }^{3}$ Diversion site. Site was not sampled; water quality for this site is simulated.

${ }^{4} \mathrm{Site}$ was not sampled; water quality is estimated from calibration data set.

${ }^{5}$ Diversion site. 
Table 10.--Averages of water-quality data used for calibrating and verifying the winter stream reach

[ft ${ }^{3} / \mathrm{s}$, cubic foot per second; ${ }^{\circ} \mathrm{C}$, degrees Celsius; mg/L, milligrams per liter; CAL, calibration; VER, verification; --, not applicable]

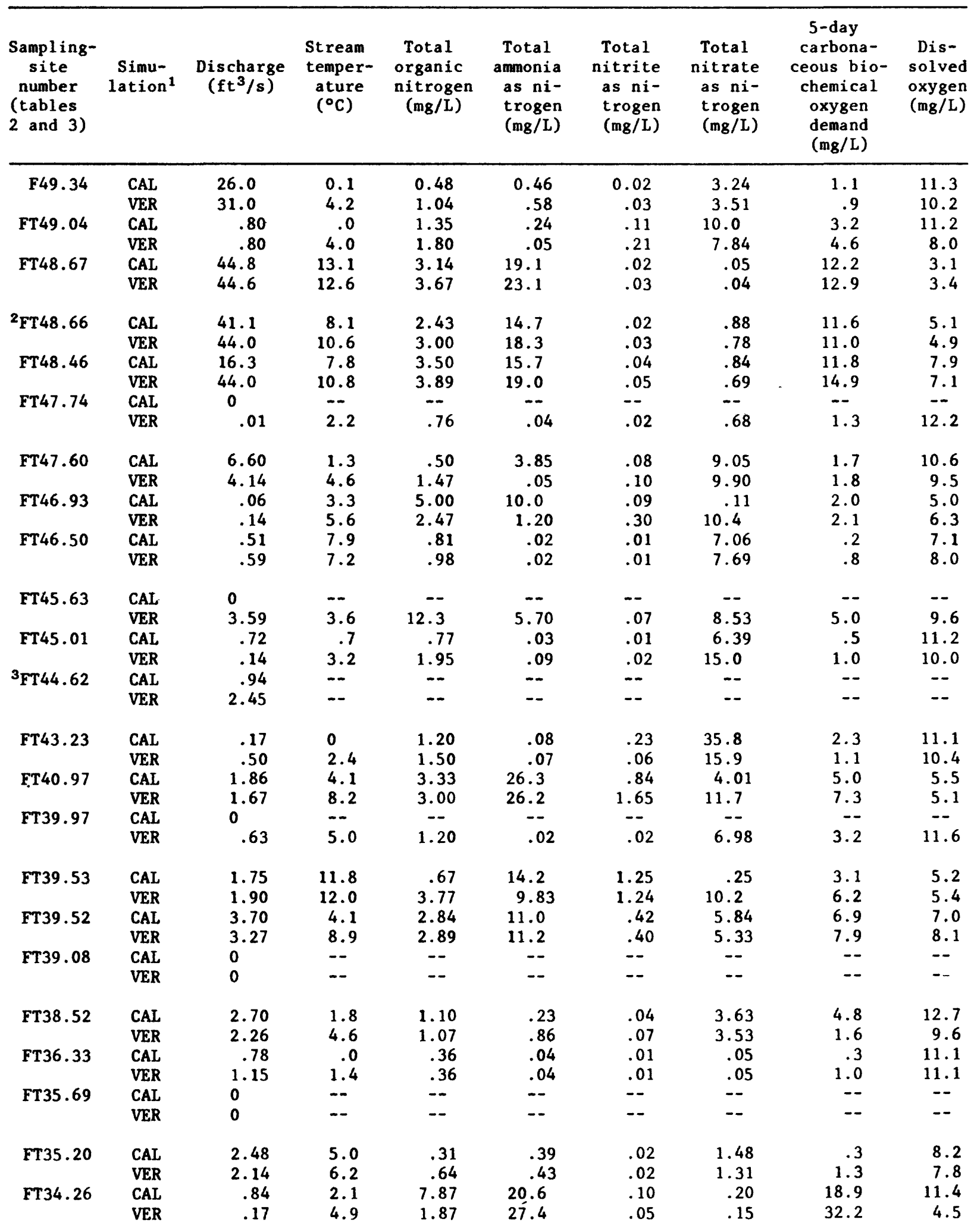


Table 10.--Averages of water-quality data used for calibrating and verifying the winter stream reach--Continued

\begin{tabular}{|c|c|c|c|c|c|c|c|c|c|}
\hline $\begin{array}{l}\text { Sampling- } \\
\text { site } \\
\text { number } \\
\text { (tables } \\
2 \text { and } 3 \text { ) }\end{array}$ & $\begin{array}{l}\text { Simu- } \\
\text { lation } 1\end{array}$ & $\begin{array}{c}\text { Discharge } \\
\left(\mathrm{ft}^{3} / \mathrm{s}\right)\end{array}$ & $\begin{array}{l}\text { Stream } \\
\text { temper- } \\
\text { ature } \\
\left({ }^{\circ} \mathrm{C}\right)\end{array}$ & $\begin{array}{c}\text { Total } \\
\text { organic } \\
\text { nitrogen } \\
(\mathrm{mg} / \mathrm{L})\end{array}$ & $\begin{array}{l}\text { Total } \\
\text { ammonia } \\
\text { as ni- } \\
\text { trogen } \\
(\mathrm{mg} / \mathrm{L})\end{array}$ & $\begin{array}{l}\text { Total } \\
\text { nitrite } \\
\text { as ni- } \\
\text { trogen } \\
(\mathrm{mg} / \mathrm{L})\end{array}$ & $\begin{array}{l}\text { Total } \\
\text { nitrate } \\
\text { as ni- } \\
\text { trogen } \\
(\mathrm{mg} / \mathrm{L})\end{array}$ & $\begin{array}{c}\text { 5-day } \\
\text { carbona- } \\
\text { ceous bio- } \\
\text { chemical } \\
\text { oxygen } \\
\text { demand } \\
(\mathrm{mg} / \mathrm{L})\end{array}$ & $\begin{array}{l}\text { Dis- } \\
\text { solved } \\
\text { oxygen } \\
(\mathrm{mg} / \mathrm{L})\end{array}$ \\
\hline \multirow[t]{2}{*}{ FT33.70 } & CAL & 0 & -- & -- & -- & -- & -- & -- & -- \\
\hline & VER & 0 & -- & -- & -- & -- & -- & -- & -- \\
\hline \multirow[t]{2}{*}{ FT33.12 } & CAL & 0 & -- & -- & -- & -- & -- & -- & -- \\
\hline & VER & 0 & -- & -- & -- & -- & -- & -- & -- \\
\hline \multirow[t]{2}{*}{ FT30. 32} & CAL & 0 & -- & -- & -- & -- & -- & -- & -- \\
\hline & VER & 0 & -- & -- & -- & -- & -- & -- & -- \\
\hline \multirow[t]{2}{*}{ FT30.06 } & CAL & 0 & -- & -- & -- & -- & -- & -- & -- \\
\hline & VER & 0 & -- & -- & -- & -- & -- & -- & -- \\
\hline \multirow[t]{2}{*}{ FT29.23 } & CAL & 0 & -- & -- & -- & -- & -- & -- & -- \\
\hline & VER & 0 & -- & -- & -- & -- & -- & -- & -- \\
\hline \multirow[t]{2}{*}{ FT26.50 } & CAL & 0 & -- & -- & -- & -- & -- & -- & -- \\
\hline & VER & 0 & -- & -- & -- & -- & -- & -- & -- \\
\hline \multirow[t]{2}{*}{ FT25.15 } & CAL & 0.74 & 2.4 & 0.24 & 0.06 & 0.01 & 0.29 & 0.2 & 9.9 \\
\hline & VER & 1.08 & 3.5 & .63 & .07 & .02 & .58 & 1.4 & 9.5 \\
\hline \multirow[t]{2}{*}{ FT24.20 } & CAL & 1.68 & 8.2 & .47 & .03 & .01 & .99 & .8 & 7.1 \\
\hline & VER & 1.82 & 11.1 & .30 & .05 & .01 & 1.39 & .8 & 6.9 \\
\hline \multirow[t]{2}{*}{ FT24.00 } & CAL & 0 & -- & -- & -- & -- & -- & -- & -- \\
\hline & VER & 0 & -- & -- & -- & -- & -- & -- & -- \\
\hline \multirow[t]{2}{*}{ FT20.84 } & CAL & 0 & -- & -- & -- & -- & -- & -- & -- \\
\hline & VER & 0 & -- & -- & -- & -- & -- & -- & -- \\
\hline \multirow[t]{2}{*}{ FT16.88 } & CAL & 0 & -- & -- & -- & -- & -- & -- & -- \\
\hline & VER & 0 & -- & -- & -- & -- & -- & -- & -- \\
\hline \multirow[t]{2}{*}{${ }^{3} \mathrm{FT} 14.00$} & CAL & 1.70 & -- & -- & -- & -- & -- & -- & -- \\
\hline & VER & 1.70 & -- & -- & -- & -- & -- & -- & -- \\
\hline \multirow[t]{2}{*}{ FT 10.89} & CAL & 0 & -- & -- & -- & -- & -- & -- & -- \\
\hline & VER & 0 & -- & -- & -- & -- & -- & -- & -- \\
\hline \multirow[t]{2}{*}{ FT8. 80} & CAL & 0 & -- & -- & -- & -- & -- & -- & -- \\
\hline & VER & 0 & -- & -- & -- & -- & -- & -- & -- \\
\hline
\end{tabular}

${ }^{1}$ Date for calibration data set is December 9-10, 1986; date for verification data set is February $10-11,1987$.

${ }^{2}$ Diversion site.

${ }^{3}$ Diversion site. Site was not sampled; water quality for this site is simulated. 
As noted in the "Data-Collection Program" section of this report, tributary sites other than wastewater outflows were sampled only one, two, or three times during each of the diel-sampling periods. Generally, this number of samples was sufficient to adequately define the average concentration of most water-quality constituents for tributaries because water quality in the tributaries did not vary greatly and because the tributary discharge usually was small in comparison to discharge in Monument and Fountain Creeks. However, because stream temperature and $D O$ have a considerable diel variation in Monument and Fountain Creeks and in their tributaries, the fewer number of samples for tributaries may not be sufficient to adequately define the average stream temperature and DO. The larger number of samples at sites on Monument and Fountain Creeks, though, was sufficient to determine the average stream temperature and DO for those sites.

Analysis of the stream-temperature and DO data for the sites on Monument and Fountain Creeks indicated a correlation between the temperature at each sampling time and the average temperature for the diel period and between the DO percent saturation at each sampling time and the average Do percent saturation for the diel period. Based on these correlations, the average stream temperature and DO for tributaries were adjusted to a value more indicative of the diel average. The adjusted average stream temperature and Do values are listed in tables 9 and 10 for the tributary sites. However, the Do values for tributaries for the winter stream reach (table 10) were not adjusted because the DO percent saturation at the time a sample was collected and average DO percent saturation for the diel period had no definite correlation.

\section{Ground Water}

Monument and Fountain Creeks are adjoined by alluvial aquifers that are hydraulically connected to the streams, enabling discharge from the aquifers to the streams and recharge from the streams to the aquifers. As a result, tributaries, wastewater outfalls, and diversions may not totally account for changes in discharge and water quality from one site to another along the streams. Such stream and aquifer interactions [ground-water discharge or recharge, referred to as incremental inflow or outflow in Brown and Barnwell (1987)] can be simulated with the QUAL2E model. For ground-water recharge, the instream water quality simulated at the location of the recharge is used to characterize the water quality of the ground-water recharge; however, the water-quality characteristics of ground-water discharge need to be specified in the model input.

Water-quality characteristics of ground-water discharge were estimated by using the following: (1) Data and interpretations presented in Edelmann and Cain (1985) and in Cain and Edelmann (1986); (2) ground-water-quality data obtained for the Fountain Creek alluvium during 1988 (D.T. Chafin, U.S. Geological Survey, written commun., 1988) for an ongoing study (Stewart, 1987, p. 20); and (3) from computer data files of the U.S. Geological Survey. 
The following water-quality characteristics for ground-water discharge were estimated:

1. A water temperature of $13.0^{\circ} \mathrm{C}$, a DO of $2.0 \mathrm{mg} / \mathrm{L}$, and a 5 -day CBOD of $1.0 \mathrm{mg} / \mathrm{L}$ were assigned to all ground-water discharge.

2. An organic nitrogen concentration of $0.2 \mathrm{mg} / \mathrm{L}$ and a nitrate concentration of $0.5 \mathrm{mg} / \mathrm{L}$ were assigned to ground-water discharge along Monument and Fountain Creeks upstream from their confluence.

3. Organic nitrogen concentration ranging from 0.2 to $1.0 \mathrm{mg} / \mathrm{L}$ and nitrate concentration ranging from 1.0 to $7.0 \mathrm{mg} / \mathrm{L}$ were assigned to ground-water discharge along Fountain Creek downstream from Monument Creek.

For the third estimation, the concentrations generally were largest for ground-water discharge in the vicinity of the Colorado Springs WWTF; the concentrations decreased in the downstream subreaches (Edelmann and Cain, 1985). In addition, concentrations of ammonia and nitrite were assumed to be $0 \mathrm{mg} / \mathrm{L}$ for all ground-water discharge.

\section{Model Estimates of Discharge and Stream Temperature}

Simulated concentrations of water-quality constituents are based on a mass-balance computation and on reaction rates. Discharge is an important component of the mass-balance computation and reaction rates are temperature dependent. Therefore, proper calibration and verification of the model requires that estimates of discharge and stream temperature are close to the values measured during the diel-sampling periods.

\section{Estimated Discharges}

During the diel-sampling periods, discharge data (Kuhn and Ortiz, 1989) were obtained for sites on Monument and Fountain Creeks (table 2), and for sites on tributaries and wastewater outfalls (table 3 ). The average discharge during the diel-sampling periods was estimated for each of these sites by using: (1) The measured discharges for each site (Kuhn and Ortiz, 1989); (2) measurements of stage made at the time of sample collection at sites on Monument and Fountain Creeks; (3) discharge records available for streamflowgaging stations; (4) discharge records provided by the WWTF plant operators; and (5) diversion records provided by the Colorado Division of Water Resources and the city of Colorado Springs. The estimated average discharges for the most upstream site on Monument and Fountain Creeks, tributaries, and wastewater outfalls are listed in tables 9 and 10 and the estimated average discharges for sites on Monument and Fountain Creeks are shown in figures 3-5. 


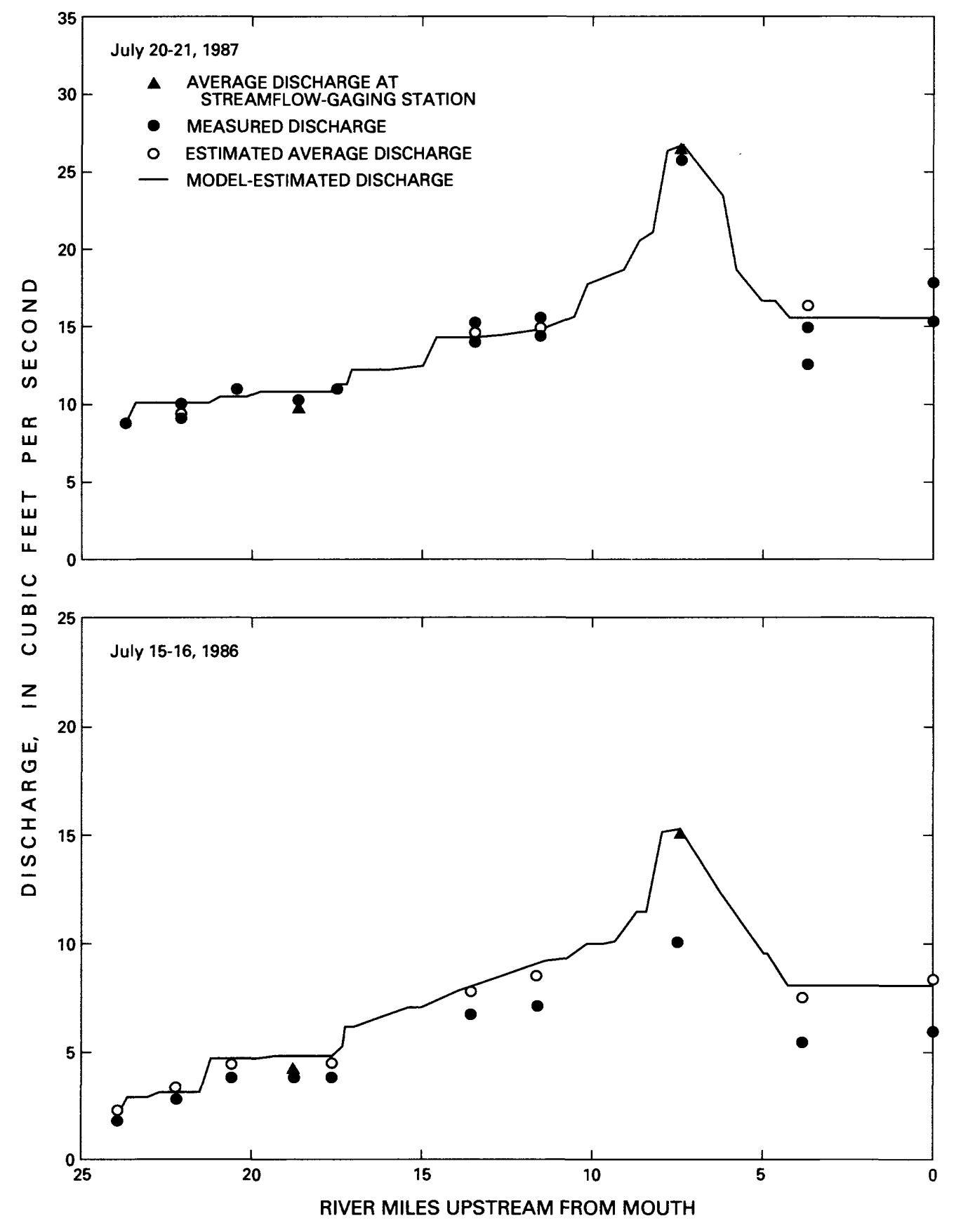

Figure 3.--Discharges for Monument Creek, July 1987 and July 1986 simulations. 


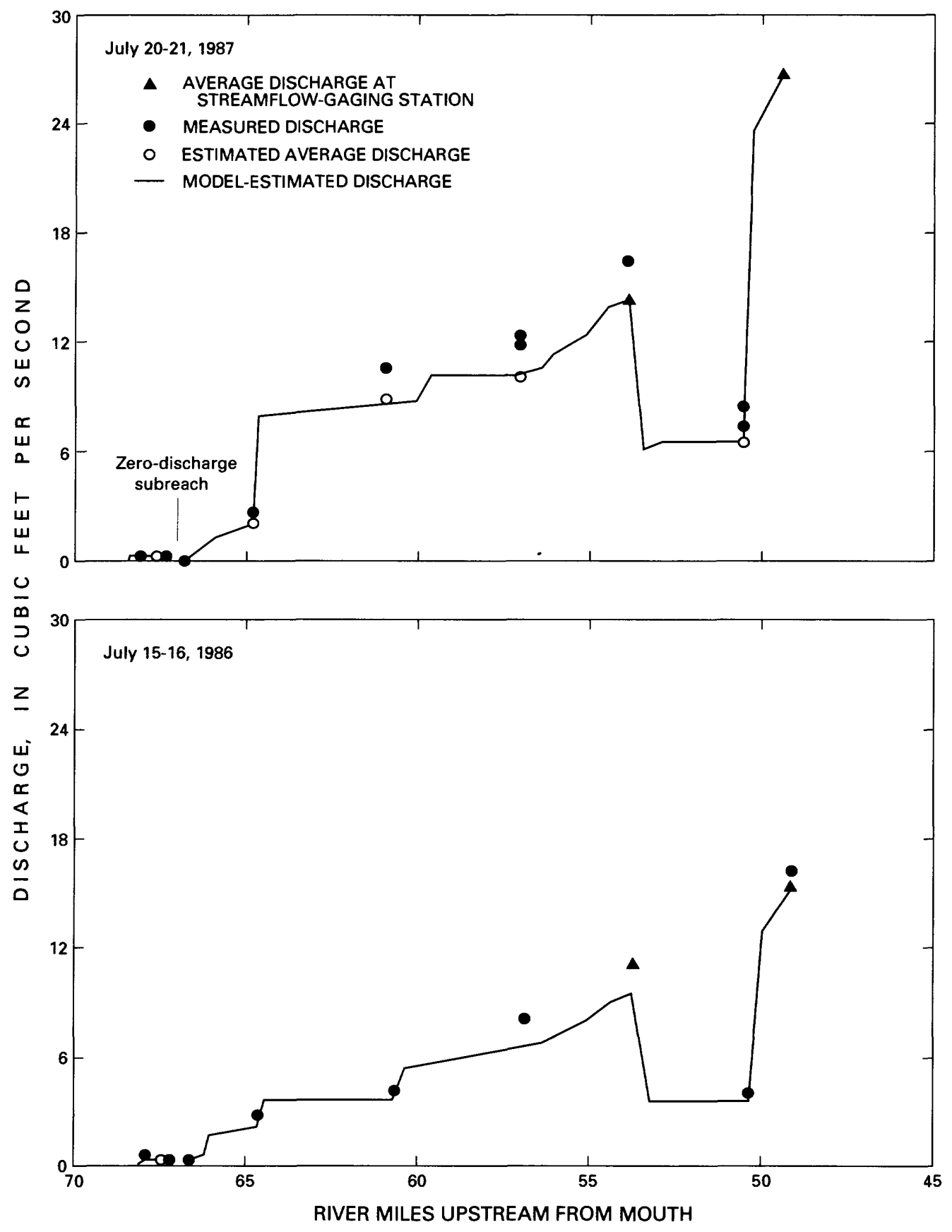

Figure 4.--Discharges for Fountain Creek, July 1987 and July 1986 simulations. 


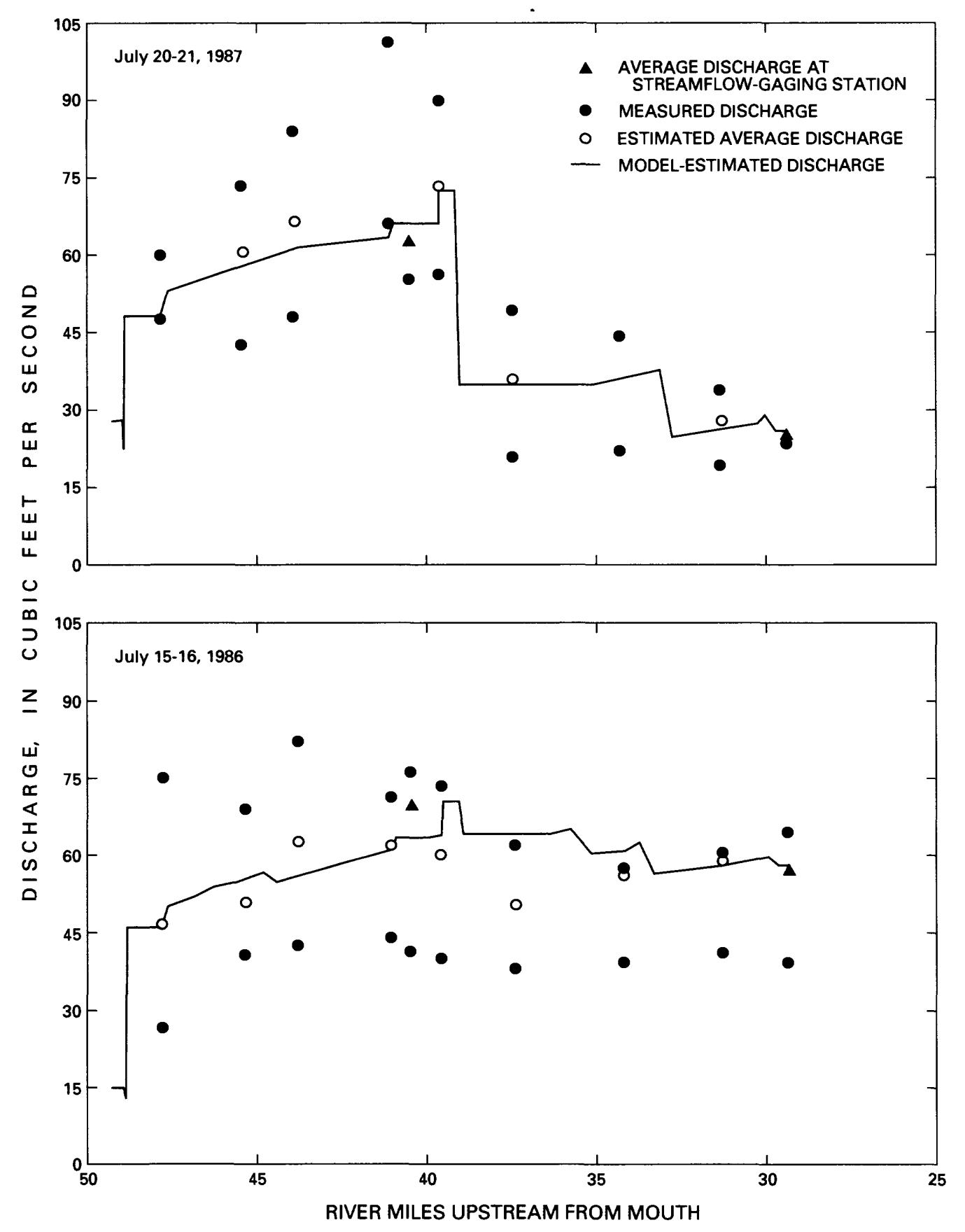

Figure 4.--Discharges for Fountain Creek, July 1987 and July 1986 simulations--Continued. 


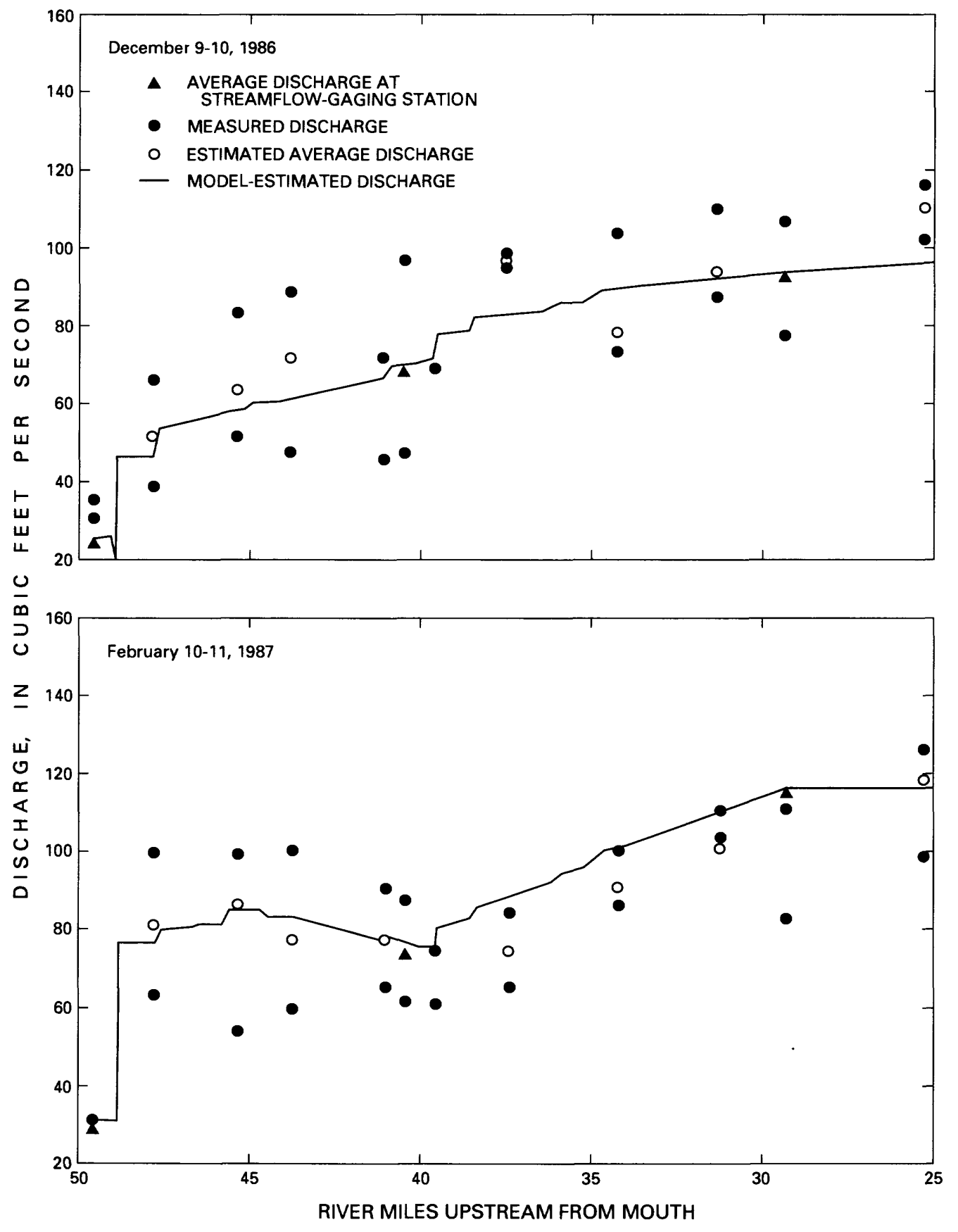

Figure 5.--Discharges for Fountain Creek, December 1986 and February 1987 simulations. 


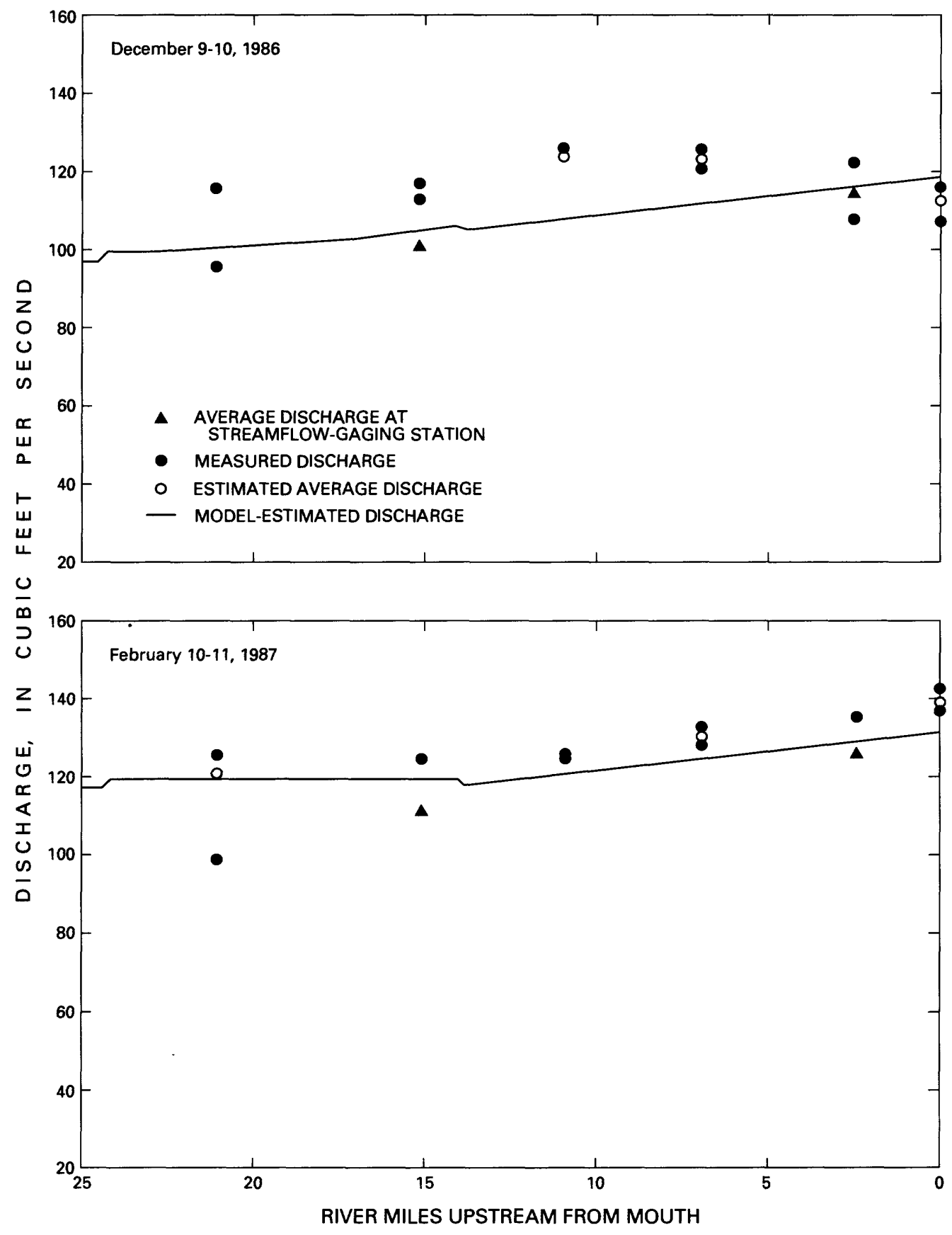

Figure 5.--Discharges for Fountain Creek, December 1986 and February 1987 simulations--Continued. 
In the model, the estimated average discharges at the most upstream site on Monument or Fountain Creeks are input along with those for each tributary, wastewater outfall, and diversion site (tables 9 and 10). The discharges for tributaries and wastewater outfalls are accumulated in a downstream direction; discharges or diversions are subtracted from the total discharge. If the model-estimated discharges and the estimated average discharges for downstream sites on Monument and Fountain Creeks were not within reasonable agreement, the model-estimated discharges were adjusted by the use of ground-water discharge or recharge for appropriate subreaches until reasonable agreement was achieved. For the analysis described here, reasonable agreement was considered to be no more than about 10 percent difference between modelestimated discharge and the estimated average discharge at sites on Monument and Fountain Creeks.

Out of 92 comparisons of estimated average discharge and model-estimated discharge, the differences were larger than 10 percent for 15 of the comparisons. The differences larger than 10 percent generally were at sites with a poor measuring section or a poor stage-discharge relation during the diel-sampling period; in these instances, the model-estimated discharge is considered to be no less accurate than the estimated average discharge. In addition, the model-estimated discharges were adjusted to agree closely with recorded average discharges at streamflow-gaging stations (fig. 1) because these sites had the most accurate discharge data during the sampling periods.

The model-estimated discharges for the calibration and verification simulations are shown in figures 3-5. Some exceptions to the criterion of close agreement with recorded average discharge at gaging stations may be seen in figures 3-5; in these instances, gradual changes in ground-water discharge or recharge were considered more reasonable than abrupt changes. The model-estimated discharges as shown in figures 3-5 were considered to be satisfactory for calibration and verification of water-quality constituents.

A zero-discharge subreach is shown in figure 4 because Fountain Creek usually is an ephemeral stream upstream from about Crystola Creek (fig. 2, area C). Upstream from site FT68.10, there was no discharge in Fountain Creek during the July 1986 and July 1987 sampling periods. Also, there was no discharge a short distance downstream from site F67.28 (fig. 2, area C) because the small quantities of discharge contributed by sites FT68.10, FT68.09, and FT67.75 (table 9) were insufficient to sustain discharge in Fountain Creek because of recharge to the alluvium and, to a lesser extent, evaporation. About $0.8 \mathrm{mi}$ downsțream from site F67.28, Fountain Creek becomes a perennial stream.

\section{Estimated Stream Temperatures}

The capability to estimate (simulate) stream temperature is an advantage of the QUAL2E model, especially for simulations other than the calibrations and verifications described in this report because estimated instream temperatures need not be input for each simulation. Stream temperature estimation by the model consists of: (1) Heat-balance computations associated with surfacewater inflow and diversion and with ground-water discharge and recharge and (2) heat-balance computations associated with the air and water interface, which include the processes of long- and short-wave radiation, convection, and evaporation. The computational methods are described in detail by Brown and Barnwell (1987, p. 57-70). 
Estimated stream temperatures for the calibration and verification simulations and the maximum, average, and minimum of the measured temperatures at sites on Monument and Fountain Creeks are shown in figures 6-8. Differences between the model-estimated stream temperatures and average measured stream temperatures for the two July simulations are smaller than the differences for the December and February simulations. These differences are explained more fully in the following paragraphs.

In order to provide flexibility in future applications of the model, modifications made to the model provided for computation of stream temperature by using monthly average air-temperature data (see "Modification of StreamTemperature Estimating Method" section of this report). Air temperatures during the December 1986 diel-sampling period were colder than the average, and during the February 1987 diel-sampling period air temperatures were warmer than the average. Thus, the model-estimated stream temperatures for the December simulation were larger than the average measured stream temperatures, and the model-estimated stream temperatures for the February simulation were smaller than the average measured stream temperatures.

Stream temperatures estimated by the model were adjusted by using the subreach-variable evaporation coefficient listed in tables 4 and 5; the values listed were used for all four calibration and verification simulations. Different evaporation coefficient values could have been used for each simulation to result in smaller differences between the model-estimated and the average measured stream temperatures, especially for the December and February simulations. However, because future applications of the model probably would be for more general hydrologic and climatologic conditions than for the specific conditions during the four diel-sampling periods, the evaporation coefficients used (tables 4 and 5 ) provided the best overall estimates of stream temperature for all four calibration and verification simulations.

The sensitivity of simulated concentrations of water-quality constituents to errors in model-estimated stream temperatures was evaluated. The notemperature-simulation option of the model was used for the evaluation; stream temperatures are specified in the input data when using this option. The July 1987 data set was simulated using input stream temperatures of 22, 25, and $28{ }^{\circ} \mathrm{C}$ and the December 1986 data set was simulated using input stream temperatures of 2,5 , and $8^{\circ} \mathrm{C}$. The percentage difference in simulated concentration of water-quality constituents at sites along middle Fountain Creek was calculated for the simulations at 22 and $28{ }^{\circ} \mathrm{C}$ using the simulation at $25{ }^{\circ} \mathrm{C}$ as the standard, and for the simulations at 2 and $8{ }^{\circ} \mathrm{C}$ using the simulation at $5{ }^{\circ} \mathrm{C}$ as the standard. 

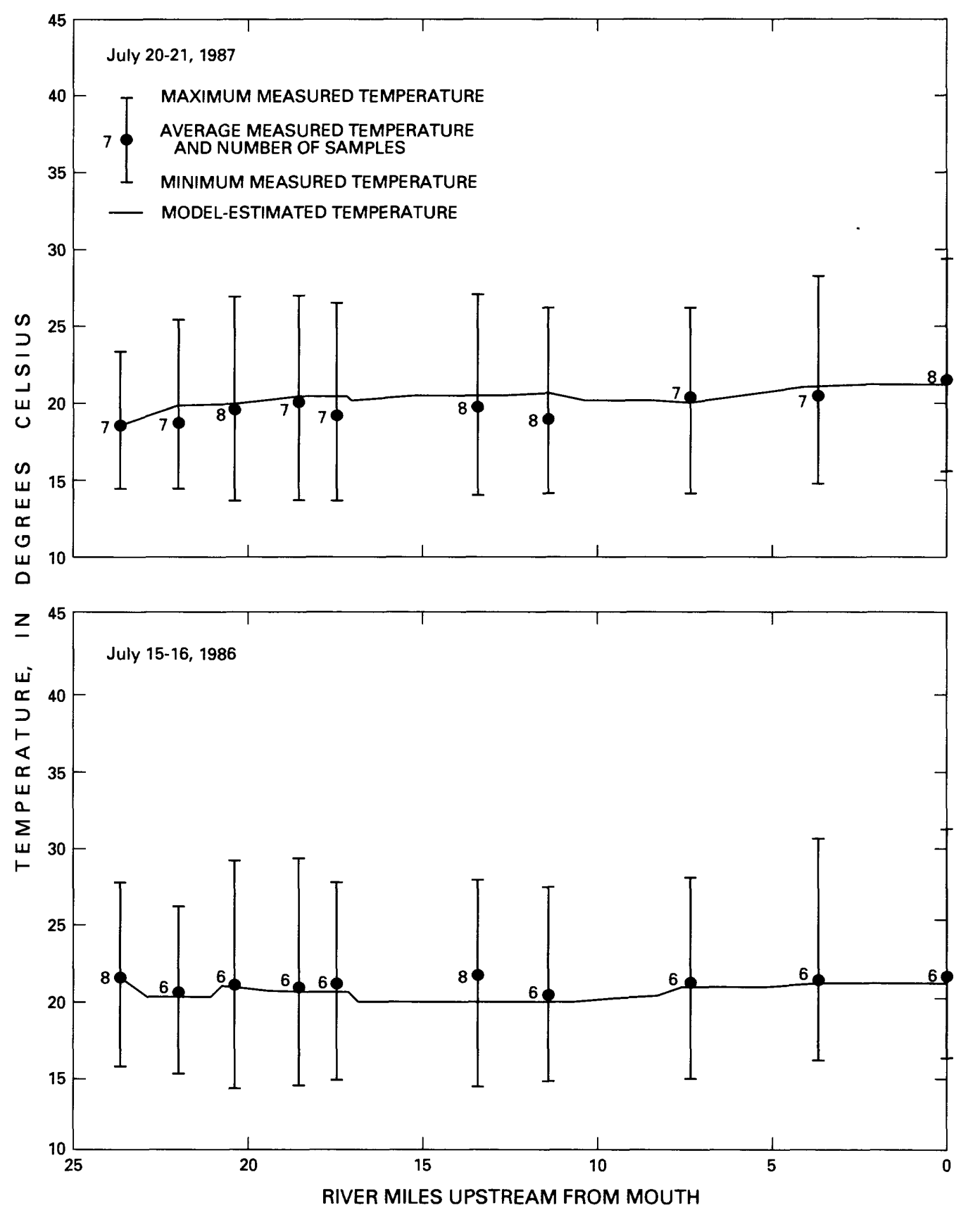

Figure 6.--Stream temperatures for Monument Creek, July 1987 and July 1986 simulations. 

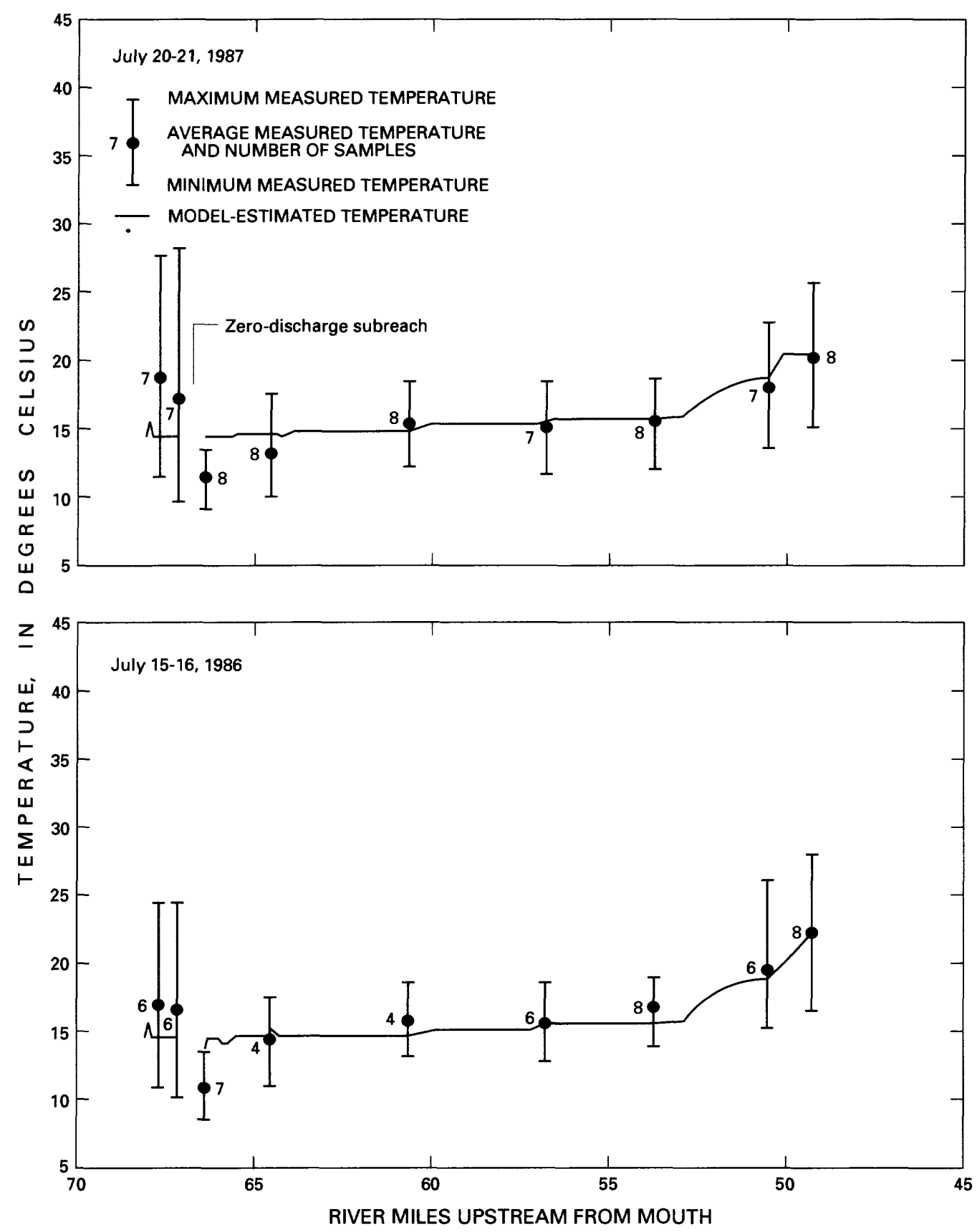

Figure 7.--Stream temperatures for Fountain Creek, July 1987 and July 1986 simulations. 

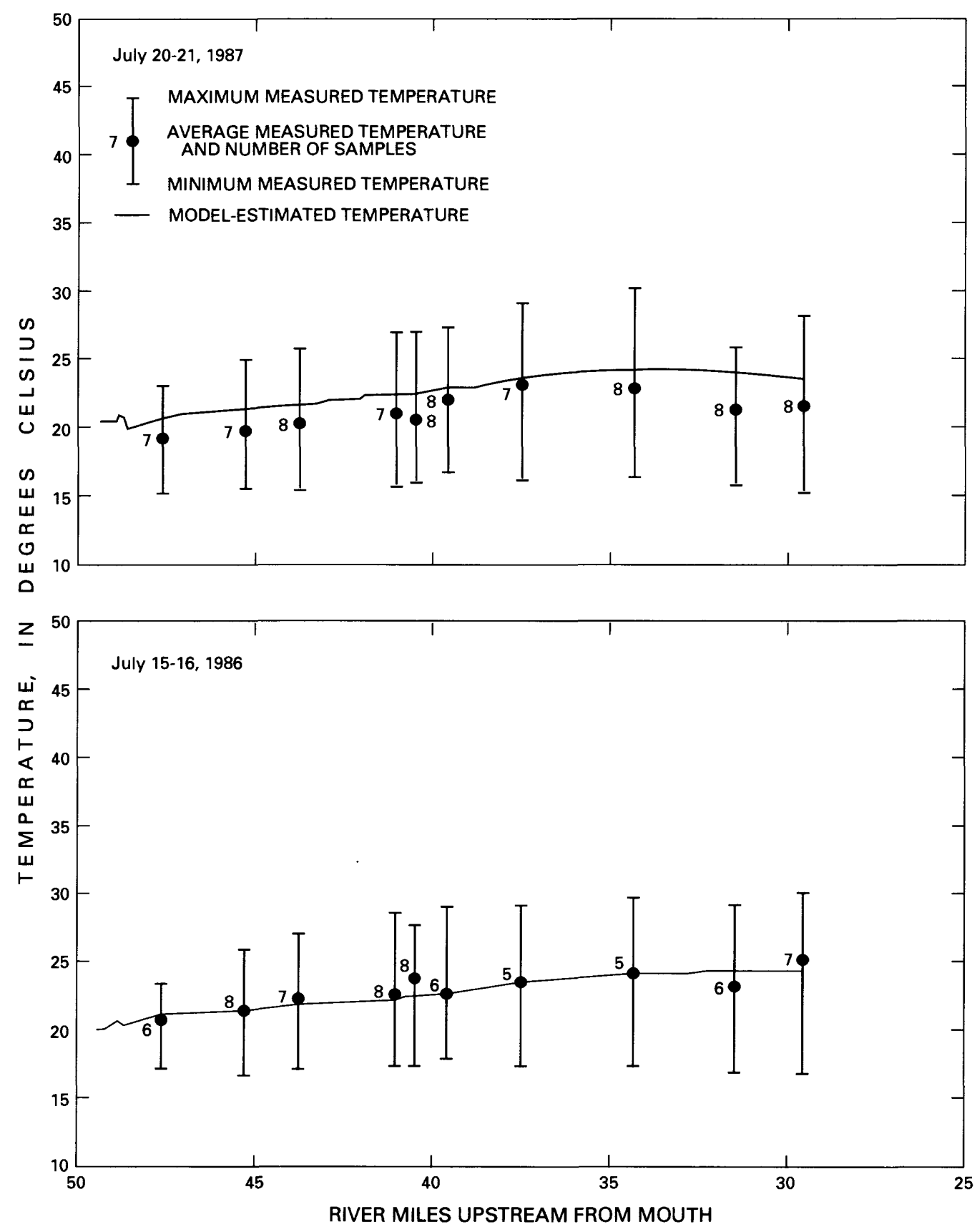

Figure 7.--Stream temperatures for Fountain Creek, July 1987 and July 1986 simulations--Continued. 

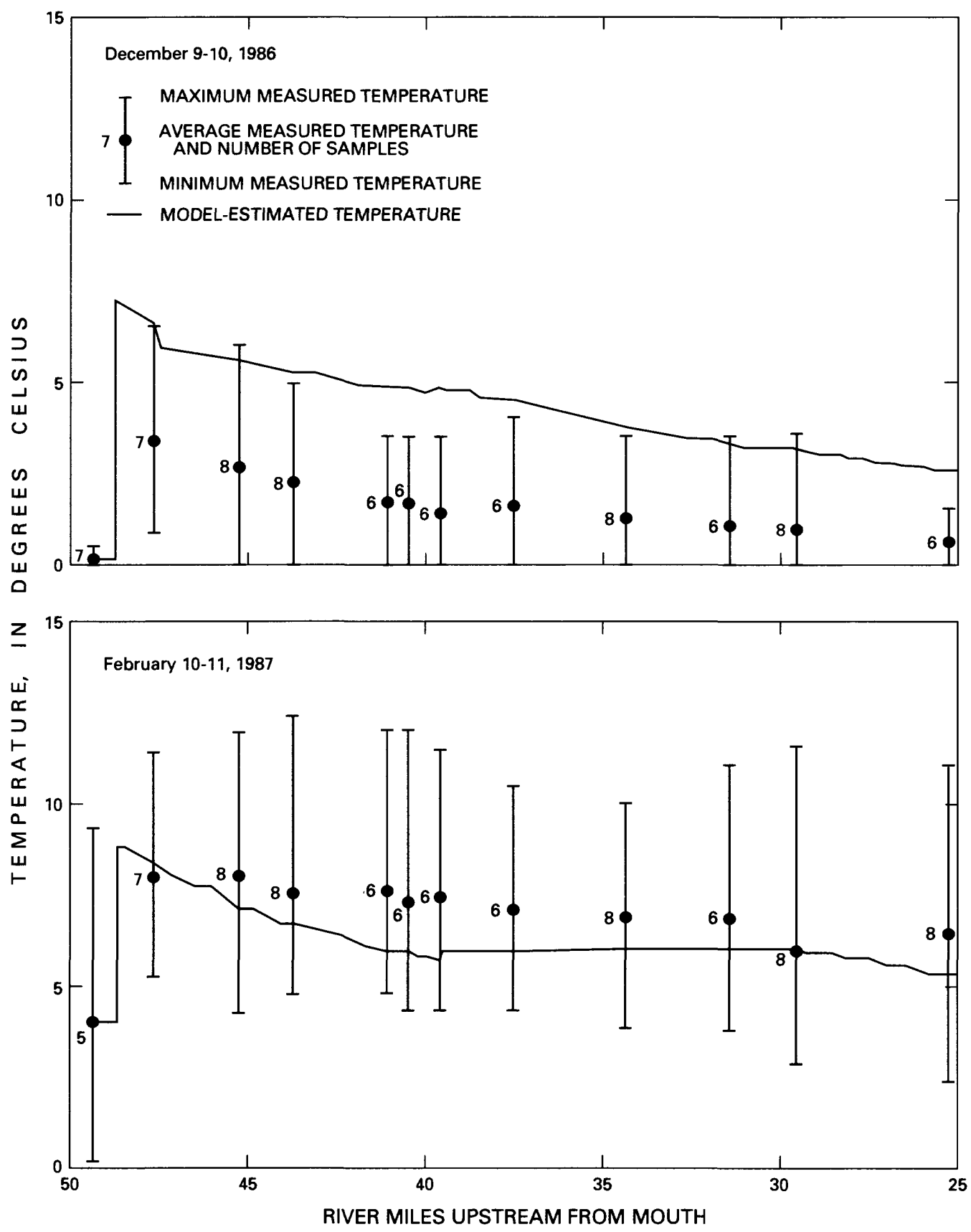

Figure 8.--Stream temperatures for Fountain Creek, December 1986 and February 1987 simulations. 

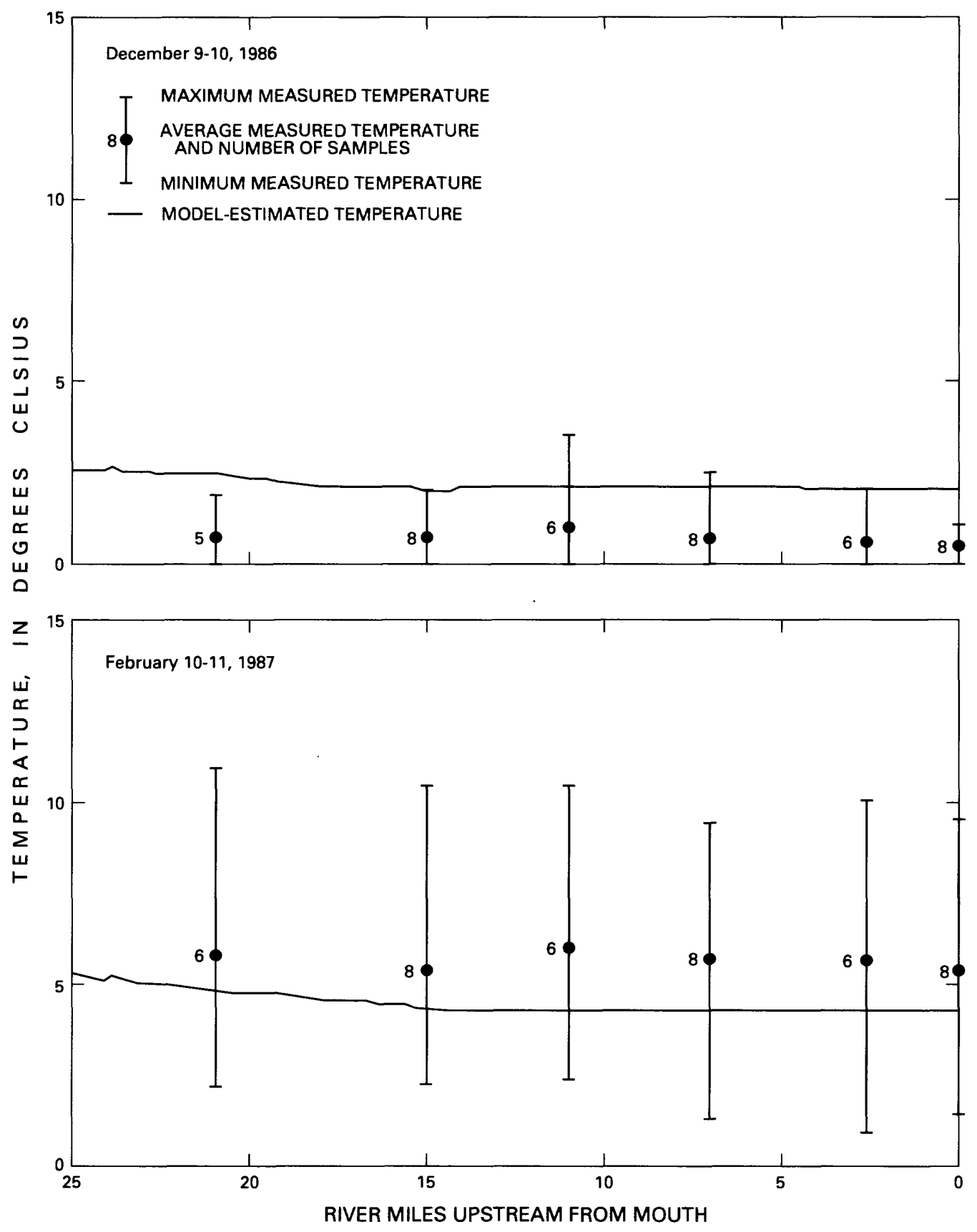

Figure 8.--Stream temperatures for Fountain Creek, December 1986 and February 1987 simulations--Continued. 
Results of this analysis are listed in table 11. Although the percentage change is large at some sites, especially for ammonia and nitrite, the larger percentages usually are for the smaller concentrations (table 11). Moreover, because the maximum error in estimated stream temperature is no greater than $3^{\circ} \mathrm{C}$ ( $f i g .8$ ), the errors in simulated concentration of water-quality constituents will be less than that indicated in table 11. Organic nitrogen and 5-day $C B O D$ were not sensitive to the $6^{\circ} \mathrm{C}$ range of stream temperature. On the basis of the discussions just presented, and the results shown in figures 6-8 and listed in table 11 , the estimated stream temperatures were considered satisfactory for calibration and verification of water-quality constituents.

\section{CALIBRATION AND VERIFICATION OF MODEI}

The results of calibrating and verifying the model for Monument and Fountain Creeks are described in this section of the report. Included in this section are: (1) A description of the model reaction coefficients and the values determined for calibrating the summer and winter stream reaches, (2) description of the method used to simulate the Colorado Springs WWTF, (3) description of the criteria used for determining the acceptability of the model calibration and verification, and (4) description of the results of the calibration and verification simulations.

\section{Reaction Coefficients}

Use of a water-quality model to evaluate the effects of wastewater discharges on Monument and Fountain Creeks requires that the model simulate the nitrification process in the streams. Nitrification is a sequence of reactions in which one nitrogen species is converted to another. The sequence consists of the conversion of organic nitrogen to ammonia, conversion of ammonia to nitrite, and conversion of nitrite to nitrate. The reaction sequence is simulated by using several reaction coefficients that indicate the rates of conversion from one nitrogen species to another.

Nitrification was simulated in the QUAL2E model by using the following reaction coefficients: (1) Forward reaction coefficients for conversion of organic nitrogen to ammonia, conversion of ammonia to nitrite, and conversion of nitrite to nitrate; (2) a settling coefficient for organic nitrogen; and (3) a decay coefficient for nitrate nitrogen. The use of the decay coefficient for nitrate was a capability added to the model for the analysis described in this report (see "Supplemental Information" section of this report).

Although nitrification usually is the most substantial component of the nitrogen cycle in a stream, other processes, such as uptake or release of nitrogen by algae, nitrogen fixation, and denitrification, also may affect concentration of nitrogen species (Bowie and others, 1985, p. 244-264). The QUAL2E model has the capability to simulate some of these processes; however, these processes were not simulated for Monument and Fountain Creeks because no data were available to describe these processes and because they were considered not to be substantial. 
Table 11.--Sensitivity of simulated concentrations of selected water-quality constituents to a 3-degree Celsius change in stream temperature at selected sites on Fountain Creek using initial stream temperatures of 25 and 5 degrees Celsius

[For simulations at 25,22 , and $28{ }^{\circ} \mathrm{C}$ (degrees Celsius), July 1987 data set was used. For simulations at 5,2 , and $8^{\circ} \mathrm{C}$, December 1986 data set was used. Simulated concentrations in milligrams per liter]

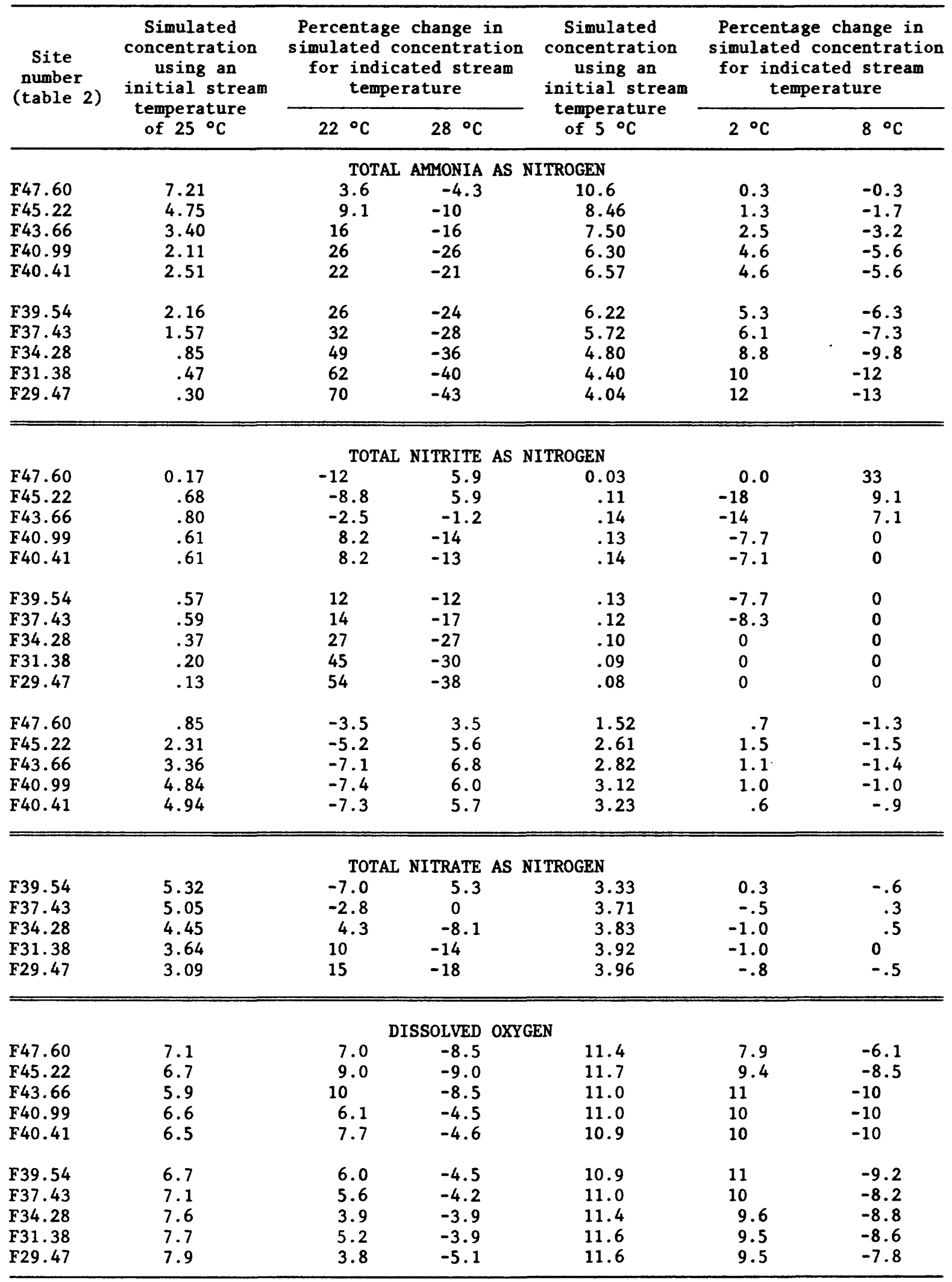


Initial model simulations indicated that for some subreaches simulated concentrations of nitrate were considerably larger than measured concentrations. Because only nitrification was considered in the analysis described in this report, loss of nitrogen only could be simulated by using the settling coefficient for organic nitrogen. Therefore, the capability to use a decay coefficient for nitrate was added to the model to indirectly provide the means for additional removal of nitrogen from the system attributable to algal uptake, denitrification, and other proceses that were not simulated.

In addition to the nitrification reaction coefficients, a deoxygenationrate coefficient also is used for simulation of CBOD. In simulating CBOD, the usual method is to input ultimate CBOD data (Bowie and others, 1985, p. 138). [Note: Ultimate CBOD is defined as the total amount of DO required by bacteria to completely oxidize decomposable organic matter under aerobic conditions (Sawyer and McCarthy, 1967, p. 394-397).] The QUAL2E model provides the capability to estimate ultimate CBOD if 5-day CBOD data are used for model input (Brown and Barnwell, 1987, p. 39-40, 95). This capability was used in this study because only 5-day CBOD data were available.

Model calibration basically consisted of adjusting the coefficients so the simulated concentrations of each nitrogen species were in reasonable agreement with the measured concentrations available from the water-quality data sets collected for this study. The adjusted reaction coefficients were verified by using an additional simulation and another water-quality data set. Reaction coefficients determined during model calibration for the summer and winter stream reaches are listed in tables 12 and 13 . The deoxygenation-rate coefficient for 5-day CBOD (tables 12 and 13) was derived from the results of the laboratory determinations of 5-day CBOD; no adjustment was made to these coefficients during model calibration.

Two values for the ammonia and nitrite forward reaction coefficients and the nitrate decay coefficient are listed in table 12 for subreach 37 (between river miles 48.67 and 48.42 ). The first of these coefficients were determined when using the actual method, whereas the second coefficients (in parentheses) were determined when using the alternate method of simulating the Colorado Springs WWTF. The following section of this report presents a detailed description of the actual and alternate simulation methods and the differences in the results of each method.

The coefficients in parentheses for subreach 37 (table 12) are not physically based coefficients to the extent of the other coefficients and apply only in the present study to the alternate simulation method. The coefficients in parentheses were determined to minimize the differences in simulated concentrations of water-quality constituents between the actual and alternate simulation methods. The coefficients determined for subreach 37 for the winter stream reach were the same for each method; the reasons why different coefficients were not needed for the alternate method are not clearly known, but may be related in part to the slower reaction rates during winter. 
Table 12.--Reaction coefficients determined during calibration for the summer stream reach

[A11 listed coefficients are in base e units at 20 degrees Celsius, in days ${ }^{-1}$ River miles are measured upstream from the mouth of Monument Creek or Fountain Creek. CBOD, carbonaceous biochemical oxygen demand; --, not applicable]

\begin{tabular}{|c|c|c|c|c|c|c|c|c|}
\hline \multirow{2}{*}{$\begin{array}{l}\text { Model } \\
\text { sub- } \\
\text { reach } \\
\text { number }\end{array}$} & $\begin{array}{l}\text { River } \\
\text { ends of }\end{array}$ & $\begin{array}{l}\text { ile at } \\
\text { subreach }\end{array}$ & \multirow{2}{*}{$\begin{array}{l}\text { Total } \\
\text { organic } \\
\text { nitrogen } \\
\text { forward } \\
\text { reaction } \\
\text { coeffi- } \\
\text { cient }\end{array}$} & \multirow{2}{*}{$\begin{array}{l}\text { Total } \\
\text { organic } \\
\text { nitrogen } \\
\text { settling } \\
\text { coeffi- } \\
\text { cient }\end{array}$} & \multirow{2}{*}{$\begin{array}{l}\text { Total } \\
\text { ammonia } \\
\quad \text { as } \\
\text { nitrogen } \\
\text { forward } \\
\text { reaction } \\
\text { coeffi- } \\
\text { cient }\end{array}$} & \multirow{2}{*}{$\begin{array}{l}\text { Total } \\
\text { nitrite } \\
\quad \text { as } \\
\text { nitrogen } \\
\text { forward } \\
\text { reaction } \\
\text { coeffi- } \\
\text { cient }\end{array}$} & \multirow{2}{*}{$\begin{array}{c}\text { Total } \\
\text { nitrate } \\
\text { as } \\
\text { nitrogen } \\
\text { decay } \\
\text { coeffi- } \\
\text { cient }\end{array}$} & \multirow{2}{*}{$\begin{array}{l}\text { 5-day } \\
\text { CBOD } \\
\text { deoxygen- } \\
\text { ation- } \\
\text { rate } \\
\text { coeffi- } \\
\text { cient }\end{array}$} \\
\hline & $\begin{array}{c}\text { Up- } \\
\text { stream }\end{array}$ & $\begin{array}{l}\text { Down- } \\
\text { stream }\end{array}$ & & & & & & \\
\hline
\end{tabular}

$\begin{array}{rrrrrrrrr}1 & 23.72 & 23.67 & 0.1 & 0 & 4.0 & 10 & 0 & 0.2 \\ 2 & 23.67 & 22.02 & .1 & 2.5 & 4.0 & 10 & 1.0 & .2 \\ 3 & 22.02 & 19.86 & .1 & 1.0 & 4.0 & 10 & 1.0 & .2 \\ 4 & 19.86 & 19.66 & .1 & .5 & 4.0 & 10 & 1.0 & .2 \\ 5 & 19.66 & 18.56 & .1 & .5 & 4.0 & 10 & 1.0 & .2 \\ 6 & 18.56 & 18.26 & .1 & .5 & 4.0 & 10 & 1.0 & .2 \\ 7 & 18.26 & 17.46 & .1 & .5 & 4.0 & 10 & 1.0 & .2 \\ 8 & 17.46 & 17.06 & .1 & 0 & 4.0 & 10 & 0 & .2 \\ 9 & 17.06 & 11.63 & .1 & 0 & 4.0 & 10 & 0 & .2 \\ 10 & 11.63 & 11.23 & .1 & 0 & 4.0 & 10 & 0 & .2 \\ 11 & 11.23 & 9.07 & .1 & 0 & 4.0 & 10 & 0 & .2 \\ 12 & 9.07 & 7.35 & .1 & 0 & 4.0 & 10 & 0 & .2 \\ 13 & 7.35 & 6.49 & .1 & 0 & 4.0 & 10 & 0 & .2 \\ 14 & 6.49 & 5.05 & .1 & 0 & 4.0 & 10 & 0 & .2 \\ 15 & 5.05 & 4.85 & .1 & 0 & 4.0 & 10 & 0 & .2 \\ 16 & 4.85 & 4.10 & .1 & 0 & 4.0 & 10 & 0 & .2 \\ 17 & 4.10 & 0.00 & .1 & 0 & 4.0 & 10 & 0 & .2\end{array}$


Table 12.--Reaction coefficients determined during calibration for the summer stream reach--Continued

\begin{tabular}{|c|c|c|c|c|c|c|c|c|}
\hline \multirow{2}{*}{$\begin{array}{l}\text { Model } \\
\text { sub- } \\
\text { reach } \\
\text { number }\end{array}$} & $\begin{array}{l}\text { River } \\
\text { ends of }\end{array}$ & $\begin{array}{l}\text { ile at } \\
\text { subreach }\end{array}$ & \multirow{2}{*}{$\begin{array}{l}\text { Total } \\
\text { organic } \\
\text { nitrogen } \\
\text { forward } \\
\text { reaction } \\
\text { coeffi- } \\
\text { cient }\end{array}$} & \multirow{2}{*}{$\begin{array}{l}\text { Total } \\
\text { organic } \\
\text { nitrogen } \\
\text { settling } \\
\text { coeffi- } \\
\text { cient }\end{array}$} & \multirow{2}{*}{$\begin{array}{l}\text { Total } \\
\text { ammonia } \\
\quad \text { as } \\
\text { nitrogen } \\
\text { forward } \\
\text { reaction } \\
\text { coeffi- } \\
\text { cient }\end{array}$} & \multirow{2}{*}{$\begin{array}{l}\text { Total } \\
\text { nitrite } \\
\quad \text { as } \\
\text { nitrogen } \\
\text { forward } \\
\text { reaction } \\
\text { coeffi- } \\
\text { cient }\end{array}$} & \multirow{2}{*}{$\begin{array}{l}\text { Total } \\
\text { nitrate } \\
\text { as } \\
\text { nitrogen } \\
\text { decay } \\
\text { coeffi- } \\
\text { cient }\end{array}$} & \multirow{2}{*}{$\begin{array}{l}\text { 5-lay } \\
\text { CBOD } \\
\text { deoxygen- } \\
\text { ation- } \\
\text { rate } \\
\text { coeffi- } \\
\text { cient }\end{array}$} \\
\hline & $\begin{array}{l}\text { Up- } \\
\text { stream }\end{array}$ & $\begin{array}{l}\text { Down- } \\
\text { stream }\end{array}$ & & & & & & \\
\hline
\end{tabular}

UPPER FOUNTAIN CREEK

$\begin{array}{rrrrlllll}218 & 68.15 & 68.10 & 0.1 & 0 & 4.0 & 80 & 0 & 0.1 \\ 219 & 68.10 & 68.05 & .1 & 0 & 4.0 & 80 & 0 & .1 \\ 220 & 68.05 & 67.75 & .1 & 0 & 4.0 & 80 & 0 & .1 \\ 221 & 67.75 & 67.27 & .1 & 0 & 4.0 & 80 & 0 & .1 \\ 322 & 67.27 & 67.08 & -- & -- & -- & -- & -- & -- \\ 323 & 67.08 & 66.57 & -- & -- & -- & -- & -- & -- \\ 24 & 66.57 & 66.52 & .1 & 0 & 4.0 & 10 & 0 & .4 \\ 25 & 66.52 & 65.92 & .1 & 0 & 4.0 & 10 & 0 & .4 \\ 26 & 65.92 & 64.58 & .1 & 0 & 4.0 & 10 & 0 & .4 \\ 27 & 64.58 & 64.38 & .1 & 0 & 4.0 & 10 & 0 & .4 \\ 28 & 64.38 & 60.74 & .1 & 0 & 4.0 & 10 & 0 & .4 \\ 29 & 60.74 & 57.34 & .1 & 0 & 4.0 & 10 & 0 & .4 \\ 30 & 57.34 & 56.46 & .1 & 0 & 4.0 & 10 & 0 & .4 \\ 31 & 56.46 & 56.10 & .1 & 0 & 4.0 & 10 & 0 & .4 \\ 32 & 56.10 & 53.85 & .1 & 0 & 4.0 & 10 & 0 & .4 \\ 33 & 53.85 & 52.95 & .1 & 0 & 4.0 & 10 & 0 & .4 \\ 34 & 52.95 & 50.61 & .1 & 0 & 4.0 & 10 & 0 & .4 \\ 35 & 50.61 & 49.34 & .1 & 0 & 4.0 & 10 & 0 & .4\end{array}$


Table 12.--Reaction coefficients determined during calibration for the summer stream reach--Continued

\begin{tabular}{|c|c|c|c|c|c|c|c|c|}
\hline \multirow{2}{*}{$\begin{array}{l}\text { Model } \\
\text { sub- } \\
\text { reach } \\
\text { number }\end{array}$} & $\begin{array}{l}\text { River } \\
\text { ends of }\end{array}$ & $\begin{array}{l}\text { le at } \\
\text { ubreach }\end{array}$ & \multirow{2}{*}{$\begin{array}{l}\text { Total } \\
\text { organic } \\
\text { nitrogen } \\
\text { forward } \\
\text { reaction } \\
\text { coeffi- } \\
\text { cient }\end{array}$} & \multirow{2}{*}{$\begin{array}{l}\text { Total } \\
\text { organic } \\
\text { nitrogen } \\
\text { settling } \\
\text { coeffi- } \\
\text { cient }\end{array}$} & \multirow{2}{*}{$\begin{array}{l}\text { Total } \\
\text { ammonia } \\
\text { as } \\
\text { nitrogen } \\
\text { forward } \\
\text { reaction } \\
\text { coeffi- } \\
\text { cient }\end{array}$} & \multirow{2}{*}{$\begin{array}{l}\text { Total } \\
\text { nitrite } \\
\quad \text { as } \\
\text { nitrogen } \\
\text { forward } \\
\text { reaction } \\
\text { coeffi- } \\
\text { cient }\end{array}$} & \multirow{2}{*}{$\begin{array}{l}\text { Total } \\
\text { nitrate } \\
\text { as } \\
\text { nitrogen } \\
\text { decay } \\
\text { coeffi- } \\
\text { cient }\end{array}$} & \multirow{2}{*}{$\begin{array}{l}\text { 5-day } \\
\text { CBOD } \\
\text { deoxygen- } \\
\text { ation- } \\
\text { rate } \\
\text { coeffi- } \\
\text { cient }^{1}\end{array}$} \\
\hline & $\begin{array}{c}\text { Up- } \\
\text { stream }\end{array}$ & $\begin{array}{l}\text { Down- } \\
\text { stream }\end{array}$ & & & & & & \\
\hline
\end{tabular}

MIDDLE FOUNTAIN CREEK

\begin{tabular}{rrrrlllll}
36 & 49.34 & 48.67 & 0.1 & 0 & 4.0 & 10 & 0 & 0.4 \\
437 & 48.67 & 48.42 & .1 & 0 & $1.0(12)$ & $80(800)$ & $2.0(150)$ & .1 \\
38 & 48.42 & 47.60 & .1 & 0 & 1.0 & 50 & 2.0 & .1 \\
39 & 47.60 & 45.62 & .1 & 0 & 2.0 & 20 & 2.0 & .1 \\
40 & 45.62 & 44.62 & .1 & 0 & 4.0 & 20 & 2.0 & .1 \\
41 & 44.62 & 43.66 & .1 & 0 & 4.0 & 20 & 0 & .1 \\
42 & 43.66 & 40.99 & .1 & 0 & 4.0 & 20 & 0 & .1 \\
43 & 40.99 & 39.54 & .1 & 0 & 4.0 & 20 & 0 & .1 \\
44 & 39.54 & 39.44 & .1 & 0 & 4.0 & 20 & 0 & .1 \\
45 & 39.44 & 37.64 & .1 & 0 & 4.0 & 20 & 2.0 & .1 \\
46 & 37.64 & 36.59 & .1 & 0 & 4.0 & 20 & 2.0 & .1 \\
47 & 36.59 & 36.07 & .1 & 0 & 4.0 & 20 & 2.0 & .1 \\
48 & 36.07 & 35.69 & .1 & 0 & 4.0 & 20 & 2.0 & .1 \\
49 & 35.69 & 34.28 & .1 & 0 & 4.0 & 20 & 2.0 & .1 \\
50 & 34.28 & 31.38 & .1 & 0 & 4.0 & 20 & 2.0 & .1 \\
& & & & & & & & \\
51 & 31.38 & 29.79 & .1 & 0 & 4.0 & 20 & 2.0 & .1 \\
52 & 29.79 & 29.47 & .1 & 0 & 4.0 & 20 & 2.0 & .1 \\
\hline
\end{tabular}

${ }^{1}$ Coefficient derived from laboratory analyses of samples for 5-day carbonaceous biochemical oxygen demand.

${ }^{2}$ Listed coefficients are inconclusive; see "Upper Fountain Creek" results for explanation.

${ }^{3}$ Zero-discharge subreach.

${ }^{4}$ Number in parentheses is coefficient determined using the alternate method to simulate the Colorado Springs Wastewater-Treatment Facility; see text for detailed explanation. 
Table 13.--Reaction coefficients determined during calibration for the winter stream reach

[A11 listed coefficients are in base e units at 20 degrees Celsius, in days ${ }^{-1}$. River miles are measured upstream from the mouth of Fountain Creek. CBOD, carbonaceous biochemical oxygen demand]

\begin{tabular}{|c|c|c|c|c|c|c|c|c|}
\hline \multirow{2}{*}{$\begin{array}{l}\text { Model } \\
\text { sub- } \\
\text { reach } \\
\text { number }\end{array}$} & \multicolumn{2}{|c|}{$\begin{array}{l}\text { River mile at } \\
\text { ends of subreach }\end{array}$} & \multirow{2}{*}{$\begin{array}{l}\text { Total } \\
\text { organic } \\
\text { nitrogen } \\
\text { forward } \\
\text { reaction } \\
\text { coeffi- } \\
\text { cient }\end{array}$} & \multirow{2}{*}{$\begin{array}{l}\text { Total } \\
\text { organic } \\
\text { nitrogen } \\
\text { settling } \\
\text { coeffi- } \\
\text { cient }\end{array}$} & \multirow{2}{*}{\begin{tabular}{l} 
Total \\
ammonia \\
\multicolumn{1}{c}{ as } \\
nitrogen \\
forward \\
reaction \\
coeffi- \\
cient
\end{tabular}} & \multirow{2}{*}{$\begin{array}{l}\text { Total } \\
\text { nitrite } \\
\quad \text { as } \\
\text { nitrogen } \\
\text { forward } \\
\text { reaction } \\
\text { coeffi- } \\
\text { cient }\end{array}$} & \multirow{2}{*}{$\begin{array}{l}\text { Total } \\
\text { nitrate } \\
\text { as } \\
\text { nitrogen } \\
\text { decay } \\
\text { coeffi- } \\
\text { cient }\end{array}$} & \multirow{2}{*}{$\begin{array}{l}\text { 5-day } \\
\text { CBOD } \\
\text { deoxygen- } \\
\text { ation- } \\
\text { rate } \\
\text { coeffi- } \\
\text { cient }\end{array}$} \\
\hline & $\begin{array}{c}\text { Up- } \\
\text { stream }\end{array}$ & $\begin{array}{l}\text { Down- } \\
\text { stream }\end{array}$ & & & & & & \\
\hline \multicolumn{9}{|c|}{ MIDDLE FOUNTAIN CREEK } \\
\hline $\begin{array}{l}35 a \\
36 \\
37 \\
38 \\
39\end{array}$ & $\begin{array}{l}49.39 \\
49.34 \\
48.67 \\
48.42 \\
47.60\end{array}$ & $\begin{array}{l}49.34 \\
48.67 \\
48.42 \\
47.60 \\
45.62\end{array}$ & $\begin{array}{r}0.1 \\
.1 \\
.1 \\
.1 \\
.1\end{array}$ & $\begin{array}{l}0 \\
0 \\
0 \\
0 \\
0\end{array}$ & $\begin{array}{l}4.0 \\
4.0 \\
1.0 \\
1.0 \\
2.0\end{array}$ & $\begin{array}{l}120 \\
120 \\
200 \\
180 \\
160\end{array}$ & $\begin{array}{r}0 \\
0 \\
10 \\
10 \\
10\end{array}$ & $\begin{array}{r}0.5 \\
.5 \\
.5 \\
.5 \\
.5\end{array}$ \\
\hline $\begin{array}{l}40 \\
41 \\
42 \\
43 \\
44\end{array}$ & $\begin{array}{l}45.62 \\
44.62 \\
43.66 \\
40.99 \\
39.54\end{array}$ & $\begin{array}{l}44.62 \\
43.66 \\
40.99 \\
39.54 \\
39.44\end{array}$ & $\begin{array}{l}.1 \\
.1 \\
.1 \\
.1 \\
.1\end{array}$ & $\begin{array}{l}0 \\
0 \\
0 \\
0 \\
0\end{array}$ & $\begin{array}{l}4.0 \\
4.0 \\
4.0 \\
4.0 \\
4.0\end{array}$ & $\begin{array}{l}140 \\
130 \\
120 \\
120 \\
120\end{array}$ & $\begin{array}{l}10 \\
10 \\
8.0 \\
5.0 \\
3.0\end{array}$ & $\begin{array}{l}.5 \\
.5 \\
.5 \\
.5 \\
.5\end{array}$ \\
\hline $\begin{array}{l}45 \\
46 \\
47 \\
48 \\
49\end{array}$ & $\begin{array}{l}39.44 \\
37.64 \\
36.59 \\
36.07 \\
35.69\end{array}$ & $\begin{array}{l}37.64 \\
36.59 \\
36.07 \\
35.69 \\
34.28\end{array}$ & $\begin{array}{l}.1 \\
.1 \\
.1 \\
.1 \\
.1\end{array}$ & $\begin{array}{l}0 \\
0 \\
0 \\
0 \\
0\end{array}$ & $\begin{array}{l}4.0 \\
4.0 \\
4.0 \\
4.0 \\
4.0\end{array}$ & $\begin{array}{l}120 \\
120 \\
120 \\
120 \\
120\end{array}$ & $\begin{array}{l}3.0 \\
3.0 \\
3.0 \\
3.0 \\
3.0\end{array}$ & $\begin{array}{l}.5 \\
.5 \\
.5 \\
.5 \\
.5\end{array}$ \\
\hline $\begin{array}{l}50 \\
51 \\
52 \\
53 \\
54\end{array}$ & $\begin{array}{l}34.28 \\
31.38 \\
29.79 \\
29.47 \\
29.23\end{array}$ & $\begin{array}{l}31.38 \\
29.79 \\
29.47 \\
29.23 \\
25.33\end{array}$ & $\begin{array}{l}.1 \\
.1 \\
.1 \\
.1 \\
.1\end{array}$ & $\begin{array}{l}0 \\
0 \\
0 \\
0 \\
0\end{array}$ & $\begin{array}{l}4.0 \\
4.0 \\
4.0 \\
4.0 \\
4.0\end{array}$ & $\begin{array}{l}120 \\
120 \\
120 \\
120 \\
120\end{array}$ & $\begin{array}{l}3.0 \\
3.0 \\
3.0 \\
3.0 \\
3.0\end{array}$ & $\begin{array}{l}.5 \\
.5 \\
.5 \\
.5 \\
.5\end{array}$ \\
\hline \multicolumn{9}{|c|}{ LOWER FOUNTAIN CREEK } \\
\hline $\begin{array}{l}55 \\
56 \\
57 \\
58 \\
59\end{array}$ & $\begin{array}{l}25.33 \\
25.15 \\
24.20 \\
24.00 \\
17.25\end{array}$ & $\begin{array}{l}25.15 \\
24.20 \\
24.00 \\
17.25 \\
14.25\end{array}$ & $\begin{array}{r}0.1 \\
.1 \\
.1 \\
.1 \\
.1\end{array}$ & $\begin{array}{l}0 \\
0 \\
0 \\
0 \\
0\end{array}$ & $\begin{array}{l}4.0 \\
10 \\
10 \\
10 \\
10\end{array}$ & $\begin{array}{l}120 \\
120 \\
120 \\
120 \\
120\end{array}$ & $\begin{array}{l}3.0 \\
2.0 \\
2.0 \\
2.0 \\
2.0\end{array}$ & $\begin{array}{r}0.5 \\
.5 \\
.5 \\
.5 \\
.5\end{array}$ \\
\hline $\begin{array}{l}60 \\
61 \\
62 \\
63 \\
64\end{array}$ & $\begin{array}{r}14.25 \\
13.75 \\
9.00 \\
8.60 \\
0.35\end{array}$ & $\begin{array}{r}13.75 \\
9.00 \\
8.60 \\
0.35 \\
0.00\end{array}$ & $\begin{array}{l}.1 \\
.1 \\
.1 \\
.1 \\
.1\end{array}$ & $\begin{array}{l}0 \\
0 \\
0 \\
0 \\
0\end{array}$ & $\begin{array}{l}10 \\
10 \\
10 \\
10 \\
10\end{array}$ & $\begin{array}{l}120 \\
120 \\
120 \\
120 \\
120\end{array}$ & $\begin{array}{l}2.0 \\
2.0 \\
2.0 \\
0 \\
0\end{array}$ & $\begin{array}{l}.5 \\
.5 \\
.5 \\
.5 \\
.5\end{array}$ \\
\hline
\end{tabular}

${ }^{1}$ Coefficient derived from laboratory analyses of samples for 5-day carbonaceous biochemical oxygen demand. 


\section{Method of Simulating Colorado Springs Wastewater-Treatment Facility}

The Colorado Springs WWTF has three separate discharge points; the configuration of these in relation to Fountain Creek and the Fountain Mutual Canal is diagrammed in figure 9. The discharge points consist of (1) an outfall from an activated-sludge plant, (2) an outfall from a tricklingfilter plant, and (3) return flow of treated wastewater used for irrigation during the summer. Outfall from the activated-sludge plant discharges directly into Fountain Creek, whereas the other outfall and the return flow discharge into the Fountain Mutual Canal diversion channel (fig. 9).

The quantity of discharge from the activated-sludge plant is large in comparison to the quantity of discharge from the trickling-filter plant. During July 1986, daily average discharge from the activated-sludge plant was $42.5 \mathrm{ft}^{3} / \mathrm{s}$, whereas daily average discharge from the trickling-filter plant was $6.9 \mathrm{ft}^{3} / \mathrm{s}$ (Laird Johnson, city of Colorado Springs, written commun., March 1988). The quantity of return-flow discharge from the wastewaterirrigation system is less than the quantity of discharge from the tricklingfilter plant.

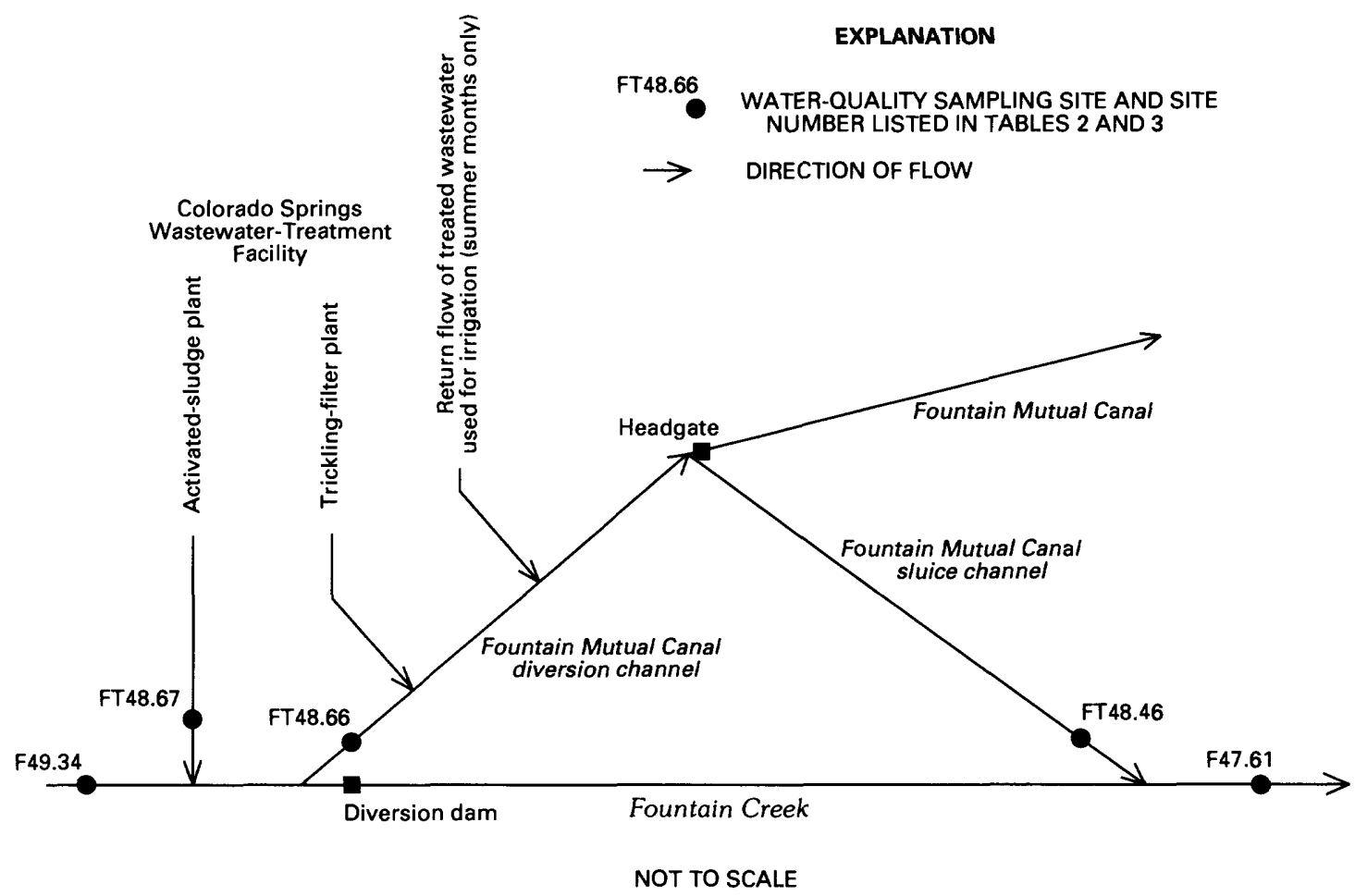

Figure 9.--Plan view schematic of Fountain Creek in vicinity of Colorado Springs Wastewater-Treatment Facility. 
The Fountain Mutual Canal diversion (site FT48.66) is about $200 \mathrm{ft}$ downstream from where the outfall from the activated-sludge plant discharges to Fountain Creek; a diversion dam (fig. 9) about $100 \mathrm{ft}$ farther downstream provides the head needed for the diversion to occur. Because the Fountain Mutual Canal diversion is only a short distance downstream from the activatedsludge plant outfall and because both are on the same bank, the discharge from the outfall and discharge in Fountain Creek are not completely mixed at the diversion. Hence, discharge in the diversion channel primarily consists of wastewater from the activated-sludge plant (Edelmann and Cain, 1985, p. 14).

The Fountain Mutual Canal headgate is located on the diversion channel about $600 \mathrm{ft}$ downstream from Fountain Creek. Excess discharge in the diversion channel not needed in the canal is returned to Fountain Creek by the sluice channel (fig. 9), which enters Fountain Creek about $0.2 \mathrm{mi}$ downstream from the diversion dam.

The diversion dam has no capability to regulate head for the diversion channel, hence, some discharge always is diverted into the diversion channel, even if the Fountain Mutual Canal is not in operation. If no discharge is needed in the canal, the headgate is closed and all discharge in the diversion channel is returned to Fountain Creek by the sluice channel.

During the four diel-sampling periods, about 55-60 percent of the total discharge in Fountain Creek between sites FT48.67 and FT48.66 was diverted into the diversion channel. This percentage probably will increase somewhat if discharge in Fountain Creek upstream from the Colorado Springs WWTF is smaller than that during the sampling periods (tables 9 and 10, site F49.34).

Sites in the vicinity of the Colorado Springs WWTF that were sampled during the diel-sampling periods, with the exception of sites FT49.04 and FT47.74 (table 3), also are shown in figure 9. Discharge data also were obtained during the sampling periods for the sampling sites shown in figure 9.

The water-quality and discharge data obtained during the diel-sampling periods were sufficient to enable actual simulation of the system as shown in figure 9 by the following method:

1. The discharge from the activated-sludge plant (site FT48.67) is simulated as a positive surface inflow to Fountain Creek.

2. The Fountain Mutual Canal diversion (site FT48.66) is simulated as a negative surface inflow to Fountain Creek; the measured water quality at site FT48.66 is used for this simulation. Simulation of site FT48.66 as a negative inflow provides the correct mass-balance computations with respect to waterquality constituents. The correct mass-balances would not be computed if the site was simulated as a diversion, because discharge in Fountain Creek and discharge from the activated-sludge plant are not completely mixed.

3. Discharge remaining in Fountain Creek is simulated from the diversion channel downstream to where the sluice channel enters the creek. 
4. The sluice channel (site FT48.46) is simulated as a positive surface inflow to Fountain Creek. Water quality at this site is different from that at the diversion (site FT48.66), primarily because of nitrification between the two sites. However, the nitrification in the diversion and sluice channels is not accounted for in the reaction coefficients determined during calibration.

Water-quality and discharge data for the diversion and sluice channels (sites FT48.66 and FT48.46) are not obtained on a routine basis. Hence, in future applications of the model, these data will not be available and simulation of the system as it actually exists by the method just described will not be possible. Therefore, an alternate method to simulate the system shown in figure 9 was developed. This method does not simulate the system as it actually exists, but provides a usable alternative. The alternate simulation method makes use of the mixing-ratio equation for discharge in the Fountain Mutual Canal derived by Edelmann and Cain (1985, p. 14):

$$
\text { MIXING RATIO }=0.0067 Q+1.01 \text {, }
$$

where $Q=$ daily average discharge at station 07105500 Fountain Creek at Colorado Springs (fig. 1; table 2, site F49.34). The mixing ratio provides an estimate of the percentage of discharge in the Fountain Mutual Canal derived from the Colorado Springs WWTF.

The mixing ratio computed by using equation 11 is applied in the following manner (Edelmann and Cain, 1985, p. 14):

1. Compute the total discharge in Fountain Creek at the Fountain Mutual Canal diversion as the sum of discharges at station 07105500 and at the Colorado Springs WWTF.

2. Compute the percentage of the total Fountain Creek discharge derived from the Colorado Springs WWTF.

3. Multiply the percentage determined in step 2 by the mixing ratio computed by using equation 11. The result indicates the percentage of the discharge in the Fountain Mutual Canal (downstream from the headgate) derived from discharge from the Colorado Springs WWTF.

The percentage of canal discharge derived from the Colorado Springs WWTF (from step 3) is multiplied by the total discharge in the Fountain Mutual Canal. The result is the estimated quantity of canal discharge derived from the Colorado Springs WWTF. The difference between the total canal discharge and the quantity derived from the WWTF is the estimated quantity of canal discharge derived from Fountain Creek.

The alternate method of simulating the system shown in figure 9 then consists of the following:

1. An assumed diversion on Fountain Creek just upstream from the Colorado Springs WWTF (site FT48.67) is used to decrease discharge in Fountain Creek by an amount equal to the quantity of discharge in the Fountain Mutual Canal that was estimated to be derived from Fountain Creek. 
2. The quantity of discharge from the Colorado Springs WWTF (site FT48.67) is decreased by an amount equal to the quantity of discharge in the Fountain Mutual Canal that was estimated to be derived from the Colorado Springs WWTF. For the alternate simulation method, the discharge at site FT48.67 consists of the total discharge from the Colorado Springs WWTF (activated-sludge outfall + trickling-filter outfall + wastewater-irrigation return flow).

3. The decreased discharge from the WWTF at site FT48.67 is simulated as a positive surface inflow to Fountain Creek, where discharge also has been decreased by the assumed diversion. The combined discharges are simulated downstream on Fountain Creek. The diversion and sluice channels (sites FT48.66 and FT48.46) are assumed not to exist.

In the alternate simulation method just described, the following assumptions are made: (1) All discharge is assumed to be in Fountain Creek between sites FT48.67 and FT48.46, rather than part of the discharge being in the diversion and sluice channels; (2) the two outfalls and the return flow at the Colorado Springs WWTF enter Fountain Creek at site FT48.67, and the waterquality characteristics of the smaller outfall and the return flow are the same as the water-quality characteristics of the activated-sludge-plant outfall; and (3) an assumed diversion exists on Fountain Creek just upstream from site FT48.67. Because of these assumptions, simulated water quality using the alternate method will be somewhat different for some subreaches from that using the actual method. The differences in water quality simulated by the two methods primarily can be attributed to the first two assumptions; differences due to the third assumption will not be substantial.

The model first was calibrated and verified by using the actual method for simulating the Colorado Springs WWTF. The actual-method calibrations then were resimulated by using the alternate method of simulating the Colorado Springs WWTF, and the differences in simulated water quality were noted for Fountain Creek downstream from river mile 48.46. The reaction coefficients for ammonia and nitrite and the decay coefficient for nitrate for subreach 37 (between river miles 48.67 and 48.42 ) were re-adjusted (table 12) for the alternate-method calibration for the summer stream reach in order to minimize the differences in simulated water quality between the two methods. No adjustment of the reaction coefficients was necessary for the winter stream reach when using the alternate method. The actual-method verifications then were resimulated by using the alternate method to reverify any changes, or lack of changes, made in the coefficients for subreach 37 .

Simulated concentrations of water-quality constituents for selected sites on Fountain Creek for each of the calibrations and verifications are listed in table 14. For the summer stream reach: (1) Concentrations of organic nitrogen simulated by using the actual and alternate methods differ between about -1.4 and $0.8 \mathrm{mg} / \mathrm{L}$ at the river miles listed; (2) concentrations of ammonia, nitrite, and nitrate simulated by using the actual method are about the same as the concentrations simulated by using the alternate method and adjusted coefficients for subreach 37 (table 12); (3) concentrations of 5-day CBOD differ between about -0.9 and $0.3 \mathrm{mg} / \mathrm{L}$; and (4) differences in concentration of DO are as large as $2.5 \mathrm{mg} / \mathrm{L}$ at river mile 48.26 , but the DO concentrations are about the same at the other river miles listed. 
Table 14.--Simulated concentrations of water-quality constituents for selected sites on Foumtain Creek using the actual and alternate methods for simulating the Colorado Springs Wastewater-Treatment Facility

[CBOD, carbonaceous biochemical oxygen demand]

\begin{tabular}{|c|c|c|c|c|c|c|}
\hline \multirow{3}{*}{$\begin{array}{l}\text { Water-quality } \\
\text { constituent }\end{array}$} & \multicolumn{6}{|c|}{$\begin{array}{l}\text { Simulated concentration, in milligrams per liter, at the indicated } \\
\text { river mile using the actual and alternate simulation methods }\end{array}$} \\
\hline & \multicolumn{2}{|c|}{ River mile 48.26} & River mile 47.60 & River mile 45.22 & \multicolumn{2}{|c|}{ River mile 43.66} \\
\hline & $\begin{array}{l}\text { Actual } \\
\text { method }\end{array}$ & $\begin{array}{l}\text { Alternate } \\
\text { method }\end{array}$ & $\begin{array}{l}\text { Actual Alternate } \\
\text { method method }\end{array}$ & $\begin{array}{l}\text { Actual Alternate } \\
\text { method method }\end{array}$ & $\begin{array}{l}\text { Actual } \\
\text { method }\end{array}$ & $\begin{array}{l}\text { Alternate } \\
\text { method }\end{array}$ \\
\hline
\end{tabular}

SUMMER STREAM REACH CALIBRATION (JULY 20-21, 1987)

\begin{tabular}{|c|c|c|c|c|c|c|c|c|c|c|}
\hline $\begin{array}{l}\text { Total } \\
\text { Total } \\
\text { Total }\end{array}$ & $\begin{array}{l}\text { organic } \\
\text { ammonia } \\
\text { nitrite }\end{array}$ & $\begin{array}{l}\text { nitrogen } \\
\text { as nitrogen } \\
\text { as nitrogen }\end{array}$ & $\begin{array}{r}4.15 \\
7.65 \\
.09\end{array}$ & $\begin{array}{r}3.35 \\
7.80 \\
.12\end{array}$ & $\begin{array}{r}4.13 \\
7.48 \\
.13\end{array}$ & $\begin{array}{r}3.33 \\
7.62 \\
.14\end{array}$ & $\begin{array}{r}3.60 \\
5.28 \\
.59\end{array}$ & $\begin{array}{r}2.94 \\
5.38 \\
.60\end{array}$ & $\begin{array}{r}3.43 \\
4.07 \\
.77\end{array}$ & $\begin{array}{r}2.82 \\
4.15 \\
.78\end{array}$ \\
\hline $\begin{array}{l}\text { Total } \\
\text { 5-day } \\
\text { Disso }\end{array}$ & $\begin{array}{l}\text { nitrate } \\
\text { CBOD } \\
\text { lved oxy8 }\end{array}$ & $\begin{array}{l}\text { as nitrogen } \\
\text { gen }\end{array}$ & $\begin{array}{l}.64 \\
6.2 \\
6.3\end{array}$ & $\begin{array}{l}.68 \\
7.1 \\
4.7\end{array}$ & $\begin{array}{l}.75 \\
6.2 \\
6.7\end{array}$ & $\begin{array}{l}.81 \\
7.1 \\
6.2\end{array}$ & $\begin{array}{l}2.09 \\
5.3 \\
5.9\end{array}$ & $\begin{array}{l}2.15 \\
6.0 \\
5.9\end{array}$ & $\begin{array}{l}2.98 \\
5.0 \\
5.1\end{array}$ & $\begin{array}{l}3.04 \\
5.7 \\
5.0\end{array}$ \\
\hline
\end{tabular}

SUMMER STREAM REACH VERIFICATION (JUY 15-16, 1986)

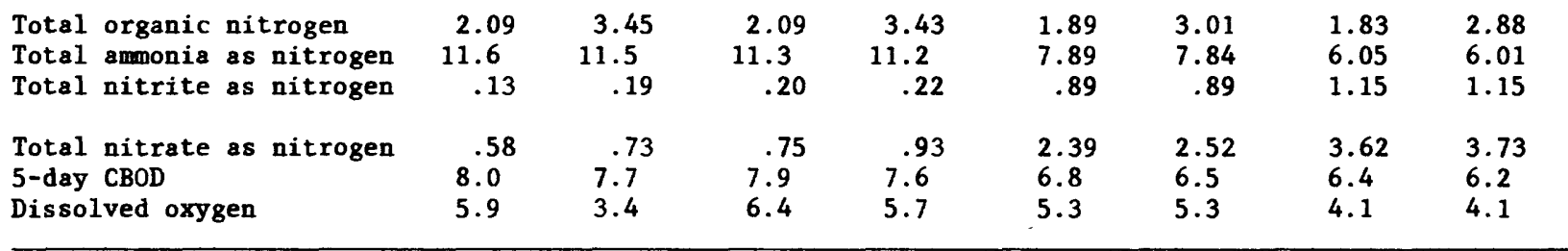

WINTER STREAM REACH CALIBRATION (DECEMBER 9-10, 1986)

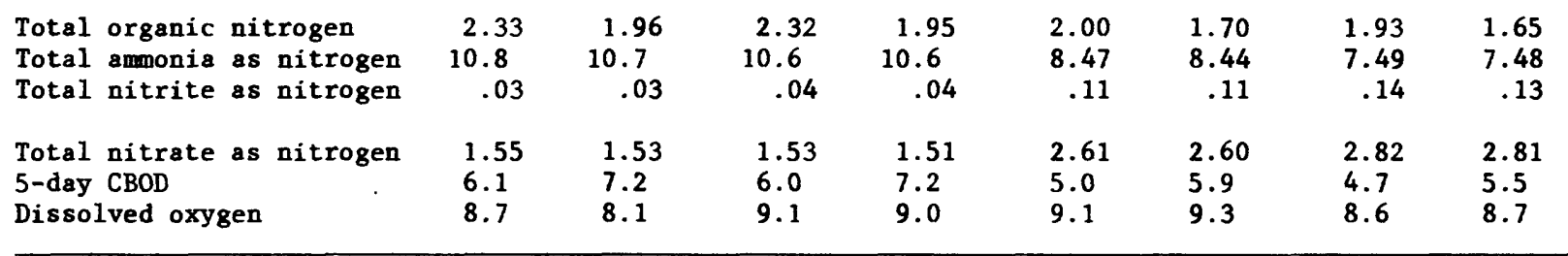

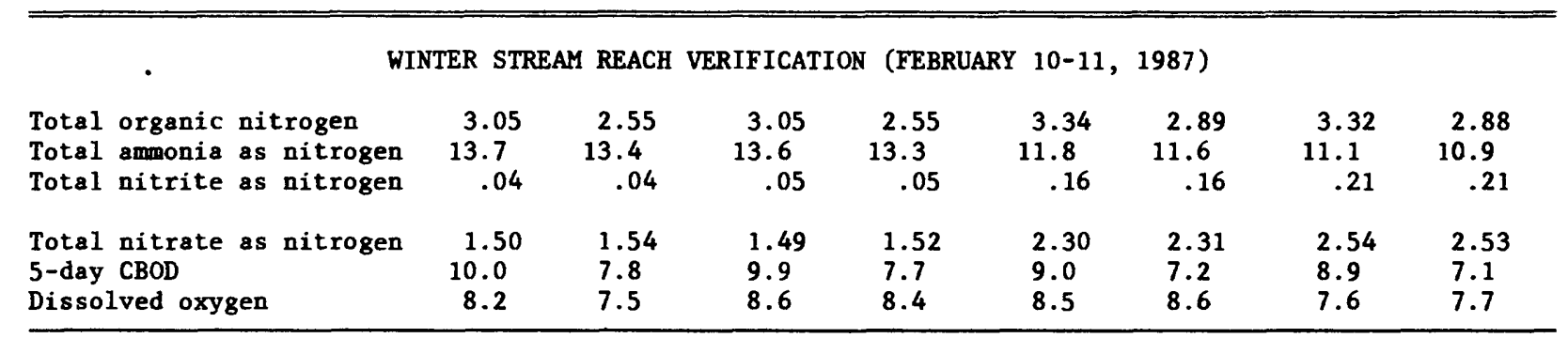


The generalizations just described also can be made for the winter stream reach calibrations and verifications, except that (1) differences in concentrations of organic nitrogen are no larger than $0.5 \mathrm{mg} / \mathrm{L}$, (2) differences in concentrations of ammonia are larger for the winter stream reach verification than for any of the other calibrations and verifications of ammonia, and (3) differences in concentration of DO at river mile 48.26 are only $0.7 \mathrm{mg} / \mathrm{L}$. For the summer and winter stream reaches, the differences in concentrations of organic nitrogen and 5-day CBOD at river mile 43.66 between the actual and alternate simulation methods (table 14) persist, but to a smaller extent, downstream from river mile 43.66. Differences in the concentrations of ammonia, nitrite, nitrate, and DO downstream from river mile 43.66 also are smaller than those at river mile 43.66 (table 14), but most often the differences are near zero.

Although the concentrations of organic nitrogen and 5-day CBOD simulated by using the alternate method consistently differed from those simulated by using the actual method, calibration and verification of the model for these two constituents for middle and lower Fountain Creeks were acceptable for the alternate method on the basis of the acceptability criteria described in the next section of this report. On the basis of the discussions just presented and the results listed in table 14 , the alternate method of simulating the Colorado Springs WWTF and the adjusted coefficients for ammonia, nitrite, and nitrate were considered to be appropriate. The alternate method, therefore, is used in all simulations described in this report; this method also was used for the estimates of discharge and stream temperature previously described. The alternate method only affected estimated discharges between river miles 48.67 and 48.42 and had no effect on estimated stream temperatures.

\section{Acceptability Criteria for Calibration and Verification}

Calibration of a water-quality model largely consists of qualitative comparisons between simulated and measured concentrations of the water-quality constituents; however, the eventual acceptability of the calibration and the verification also should be based on quantitative comparisons. Qualitative comparisons are easily made, but quantitative comparisons are more difficult. Two reasons for the difficulty in the study described in this report are: (1) Variability, sometimes quite large, in concentrations of water-quality constituents at a particular site and between sites; and (2) variability in the physical characteristics of Monument and Fountain Creeks.

No specific criteria have been established to determine the acceptability of calibration and verification of water-quality models. For example, Bauer and others (1978), Terry and others (1983) and (1984), Freeman and Schmidt (1986), and Freeman and others (1986) only used a qualitative criterion (goodness of $\mathrm{fit}$ ) for acceptability of model calibration and verification. On the other hand, Cain and others (1980, p. 24) and Spahr and Blakely (1985, p. 1819) used a qualitative and a quantitative criterion for the acceptability of calibration and verification; the qualitative criterion was that the trends of simulated and average measured concentration of water-quality constituents be similar, and the quantitative criterion was that the simulated concentration be within 20 percent of the average measured concentration in the critical stream reach downstream from a WWTF outfall. 
Both qualitative and quantitative criteria also were defined for acceptability of the calibrations and verifications described in this report. The qualitative criterion defined was that of similar trends just described in the previous paragraph. The quantitative criterion, however, was defined on the basis of the 95-percent confidence interval for the average measured concentration of each water-quality constituent at the sites on Monument and Fountain Creeks (table 2).

Statistical analysis of the water-quality data at each site indicated that the measured concentrations for each constituent for each diel-sampling period generally were normally distributed; hence, the average was the best estimator. The 95-percent confidence interval for the averages were calculated following the method described in Iman and Conover (1983, p. 189). The quantitative acceptability criterion then defined was that the simulated concentration of a water-quality constituent be within the 95-percent confidence interval of the average measured concentration at one-half or more of the sampling sites on Monument and Fountain Creeks (table 2).

Results of applying the qualitative and quantitative acceptability criteria are listed in tables 15 and 16. The acceptability criteria were applied independently to Monument Creek, upper Fountain Creek, and middle Fountain Creek for the summer stream reach (table 15) and to middle Fountain Creek and lower Fountain Creek for the winter stream reach (table 16) (see "Description of Stream Reaches" section of this report). Note that sites M23.68 and F66.52 (table 2) are the starting points for the summer stream reach and site $\mathrm{F} 49.34$ is the starting point for the winter stream reach, therefore, these sites are not included in the analysis shown in tables 15 and 16. Sites F67.76 and F67.28 (table 2) were not used in the analysis listed in table 15 (see "Upper Fountain Creek" results section of this report).

The quantitative criterion defined for the analysis described in this report was used because ( 1 ) it considers the variability in concentration of the various water-quality constituents; (2) it considers the variability in concentration of each constituent from one site to another; (3) application of a "within some percent" criterion may be misleading for small concentration values; (4) the critical stream reaches for Monument and Fountain Creeks have not been determined and the critical stream reaches may be different for different constituents, discharge conditions, and time of year; and (5) the model was calibrated for best overall performance within each section of the summer and winter stream reaches, not best performance at a particular point.

In some instances a calibration or verification was accepted even though the quantitative criterion was not met (tables 15 and 16). Also, in some instances the calibration or verification is listed as questionable; this designation is meant to imply that not accepting the calibration or verification is questionable. These instances are described in the following sections of this report that present the calibration and verification results. If the calibration for a water-quality constituent is questionable or not acceptable, no judgement can be made regarding the subsequent verification (tables 15 and 16). 
Table 15.--Acceptability results for calibrating and verifying the sumer stream reach

[CBOD, carbonaceous biochemical oxygen demand; --, not applicable]

\begin{tabular}{|c|c|c|c|c|c|c|}
\hline \multirow{3}{*}{$\begin{array}{l}\text { Water-quality } \\
\text { constituent }\end{array}$} & \multirow{2}{*}{\multicolumn{2}{|c|}{$\begin{array}{c}\text { Simulated } \\
\text { trend similar } \\
\text { to measured } \\
\text { trend }\end{array}$}} & \multirow{2}{*}{\multicolumn{2}{|c|}{$\begin{array}{l}\text { Number of sites for which the } \\
\text { simulated concentration } \\
\text { is within the 95-percent } \\
\text { confidence limits for the } \\
\text { average measured concentration }\end{array}$}} & \multicolumn{2}{|c|}{$\begin{array}{l}\text { Calibration or } \\
\text { verification } \\
\text { acceptable }\end{array}$} \\
\hline & & & & & \multirow{2}{*}{$\begin{array}{l}\text { Cali- } \\
\text { bration }\end{array}$} & \multirow{2}{*}{$\begin{array}{l}\text { Veri- } \\
\text { fication }\end{array}$} \\
\hline & $\begin{array}{c}\text { Cali- } \\
\text { bration }\end{array}$ & $\begin{array}{l}\text { Veri- } \\
\text { fication }\end{array}$ & Calibration & Verification & & \\
\hline
\end{tabular}

MONUMENT CREEK, RIVER MILE 23.67 THROUGH 0.00 ( 9 sites)

$\begin{array}{llllll}\text { Total organic nitrogen } & \text { Yes } & \text { Yes } & 9 & 5 & \text { Yes } \\ \text { Total ammonia as nitrogen } & \text { Yes } & \text { Yes } & 3 & 5 & \text { Yes } \\ \text { Total nitrite as nitrogen } & \text { Yes } & \text { Yes } & 2 & 1 & -- \\ \text { Total nitrate as nitrogen } & \text { Yes } & \text { Yes } & 4 & 3 & \text { No } \\ \begin{array}{l}\text { 5-day CBOD } \\ \text { Dissolved oxygen }\end{array} & \begin{array}{l}\text { Yes } \\ \text { Quest- } \\ \text { ionable }\end{array} & \text { Yes } & 3 & 3 & \text { Yes }^{1} \\ \end{array}$

UPPER FOUNTAIN · CREEK, RIVER MILE 66.51 THROUGH 49.34 (6 sites)

\begin{tabular}{|c|c|c|c|c|c|}
\hline $\begin{array}{l}\text { Total organic nitrogen } \\
\text { Total ammonia as nitrogen } \\
\text { Total nitrite as nitrogen }\end{array}$ & $\begin{array}{l}\text { Yes } \\
\text { Yes } \\
\text { Yes }\end{array}$ & $\begin{array}{l}\text { Yes } \\
\text { Yes } \\
\text { Yes }\end{array}$ & $\begin{array}{l}4 \\
5 \\
4\end{array}$ & $\begin{array}{l}4 \\
0 \\
1\end{array}$ & $\begin{array}{l}\text { Yes } \\
\text { Yes } \\
\text { Yes }\end{array}$ \\
\hline $\begin{array}{l}\text { Total nitrate as nitrogen } \\
\text { 5-day CBOD } \\
\text { Dissolved oxygen }\end{array}$ & $\begin{array}{l}\text { Yes } \\
\text { Yes } \\
\text { Yes }\end{array}$ & $\begin{array}{l}\text { Yes } \\
\text { Yes } \\
\text { Yes }\end{array}$ & $\begin{array}{l}0 \\
4 \\
3\end{array}$ & $\begin{array}{l}0 \\
5 \\
2\end{array}$ & $\begin{array}{l}\text { No } \\
\text { Yes } \\
\text { Yes }\end{array}$ \\
\hline
\end{tabular}

MIDDLE FOUNTAIN CREEK, RIVER MILE 49.33 THROUGH 29.47 (10 sites)

Total organic nitrogen

Total ammonia as nitrogen

Total nitrite as nitrogen

Total nitrate as nitrogen

5-day CBOD

Dissolved oxygen

$\begin{array}{ll}\text { Yes } & \text { Yes } \\ \text { Yes } & \text { Yes } \\ \text { Yes } & \text { Yes } \\ & \\ \text { Yes } & \text { No } \\ \text { Yes } & \text { Yes } \\ \text { Yes } & \text { Yes }\end{array}$

6

4

9

4

$\begin{array}{ll}\text { Yes } & \text { Yes } \\ \text { Yes } & \text { Yes } \\ \text { Yes } & \text { No } \\ \text { Yes } & \text { No } \\ \text { Yes } & \text { Yes } \\ \text { Quest- } & -- \\ \text { ionable } & \end{array}$

${ }^{1}$ Acceptable because simulated and measured concentrations generally were less than 2.5 milligrams per liter.

${ }^{2}$ Acceptable because simulated and measured concentrations generally were less than 6.0 milligrams per liter.

${ }^{3}$ Acceptable because simulated and measured concentrations generally were less then 0.05 milligrams per liter.

${ }^{4}$ Reasons for accepting the calibration are described in the "Middle Fountain Creek" section of this report. 
Table 16.--Acceptability results for calibrating and verifying the winter stream reach

[CBOD, carbonaceous biochemical oxygen demand; --, not applicable]

\begin{tabular}{|c|c|c|c|c|c|c|}
\hline \multirow{3}{*}{$\begin{array}{l}\text { Water-quality } \\
\text { constituent }\end{array}$} & \multirow{2}{*}{\multicolumn{2}{|c|}{$\begin{array}{l}\text { Simulated } \\
\text { trend similar } \\
\text { to measured } \\
\text { trend }\end{array}$}} & \multirow{2}{*}{\multicolumn{2}{|c|}{$\begin{array}{l}\text { Number of sites for which the } \\
\text { simulated concentration } \\
\text { is within the 95-percent } \\
\text { confidence limits for the } \\
\text { average measured concentration }\end{array}$}} & \multicolumn{2}{|c|}{$\begin{array}{l}\text { Calibration or } \\
\text { verification } \\
\text { acceptable }\end{array}$} \\
\hline & & & & & \multirow{2}{*}{$\begin{array}{l}\text { Cali- } \\
\text { bration }\end{array}$} & \multirow{2}{*}{$\begin{array}{l}\text { Veri- } \\
\text { fication }\end{array}$} \\
\hline & $\begin{array}{c}\text { Cali- } \\
\text { bration }\end{array}$ & $\begin{array}{l}\text { Veri- } \\
\text { fication }\end{array}$ & Calibration & Verification & & \\
\hline
\end{tabular}

MIDDLE FOUNTAIN CREER, RIVER MILE 49.33 THROUGH 25.33 (10 sites)

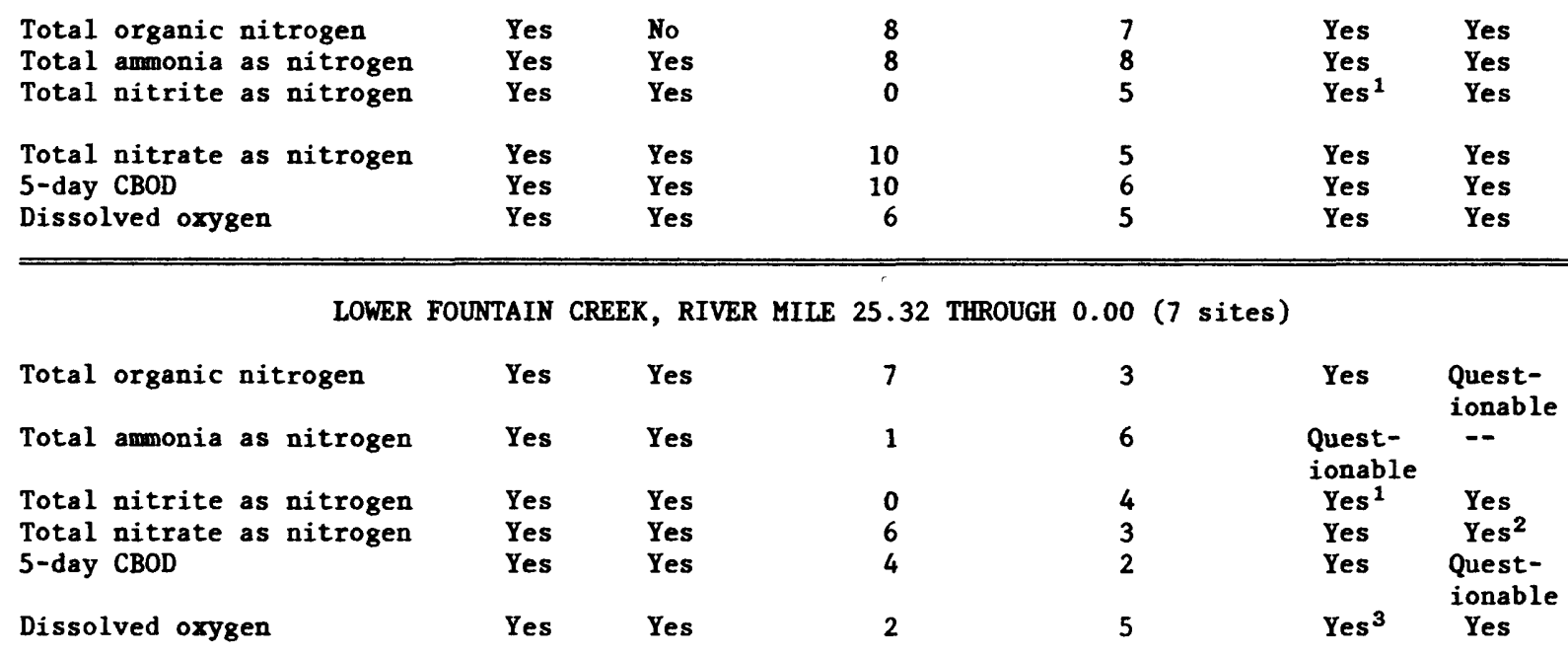

${ }^{1}$ Acceptable because simulated and measured concentrations were less than 0.2 milligrams per liter.

${ }^{2}$ Acceptable because differences between simulated and average measured concentrations generally were no larger than 1 milligram per liter.

${ }^{3}$ Acceptable because most measured concentrations of dissolved oxygen were larger than saturation. 
Results for Summer Stream Reach

The summer stream reach was calibrated by using the July 1987 waterquality and discharge data set and was verified using the July 1986 data set (see "Data-Collection Program" section of this report). Results of the calibration and verification simulations are presented simultaneously for ease of discussion and comparison of the differences and similarities in simulated and measured concentrations of water-quality constituents. The results are presented separately for Monument Creek, upper Fountain Creek, and middle Fountain Creek. In addition, for comparison of the simulated and measured concentrations of nitrite, nitrate, and DO to the water-quality standards for these constituents (table 1), the water-quality standards are shown as a horizontal dashed line in the figures showing the calibration and verification results; if the water-quality standard is outside of the concentration range shown in a figure, the standard is indicated numerically.

\section{Monument Creek}

Acceptable calibration and verification of organic nitrogen were achieved for Monument Creek (fig. 10; table 15) by using a uniform forward reaction coefficient of 0.1 days $^{-1}$ at $20^{\circ} \mathrm{C}$ (table 12). (All coefficients hereinafter mentioned are at $20^{\circ} \mathrm{C}$.) The use of an organic nitrogen settling coefficient (table 12) for six subreaches downstream from the Tri-Lakes WWTF (river mile 23.67) resulted in a more accurate calibration for organic nitrogen than that which could have been achieved by using a larger forward reaction coefficient for those subreaches. Some organic nitrogen may be in the suspended phase and could be settling out in the numerous beaver ponds observed in these subreaches at the time of sample collection. The use of the organic nitrogen settling coefficient for the six subreaches was verified (fig. 10; table 15).

An acceptable calibration for ammonia could not be achieved for Monument Creek even though the trends of the simulated and measured concentrations are similar (fig. 11; table 15). Although an acceptable calibration for ammonia may be possible by using larger forward reaction coefficients for some subreaches, the larger coefficients would be questionable because: (1) Most forward reaction coefficients for ammonia that were determined for this study were no larger than 4.0 days $^{-1}$ (tables 12 and 13) and (2) the larger reaction coefficients probably would not have been verifiable (fig. 11). Because ammonia was not calibrated, no judgment could be made regarding the acceptability of the verification (table 15), even though the simulated and measured concentrations are similar (fig. 11).

Acceptable calibration for nitrite also could not be achieved for Monument Creek (fig. 12; table 15), largely because ammonia was not calibrated. The forward reaction coefficient determined for nitrite was 10 days $^{-1}$ (table 12). As in the calibration for ammonia, larger forward reaction coefficients for nitrite (table 12) could be used for some subreaches to improve the calibration results, but the use of the larger coefficients also would be questionable for the same reasons as those for ammonia. Nitrite concentration exceeded the water-quality standard of $0.5 \mathrm{mg} / \mathrm{L}$ for some subreaches for the verification simulation (fig. 12). 


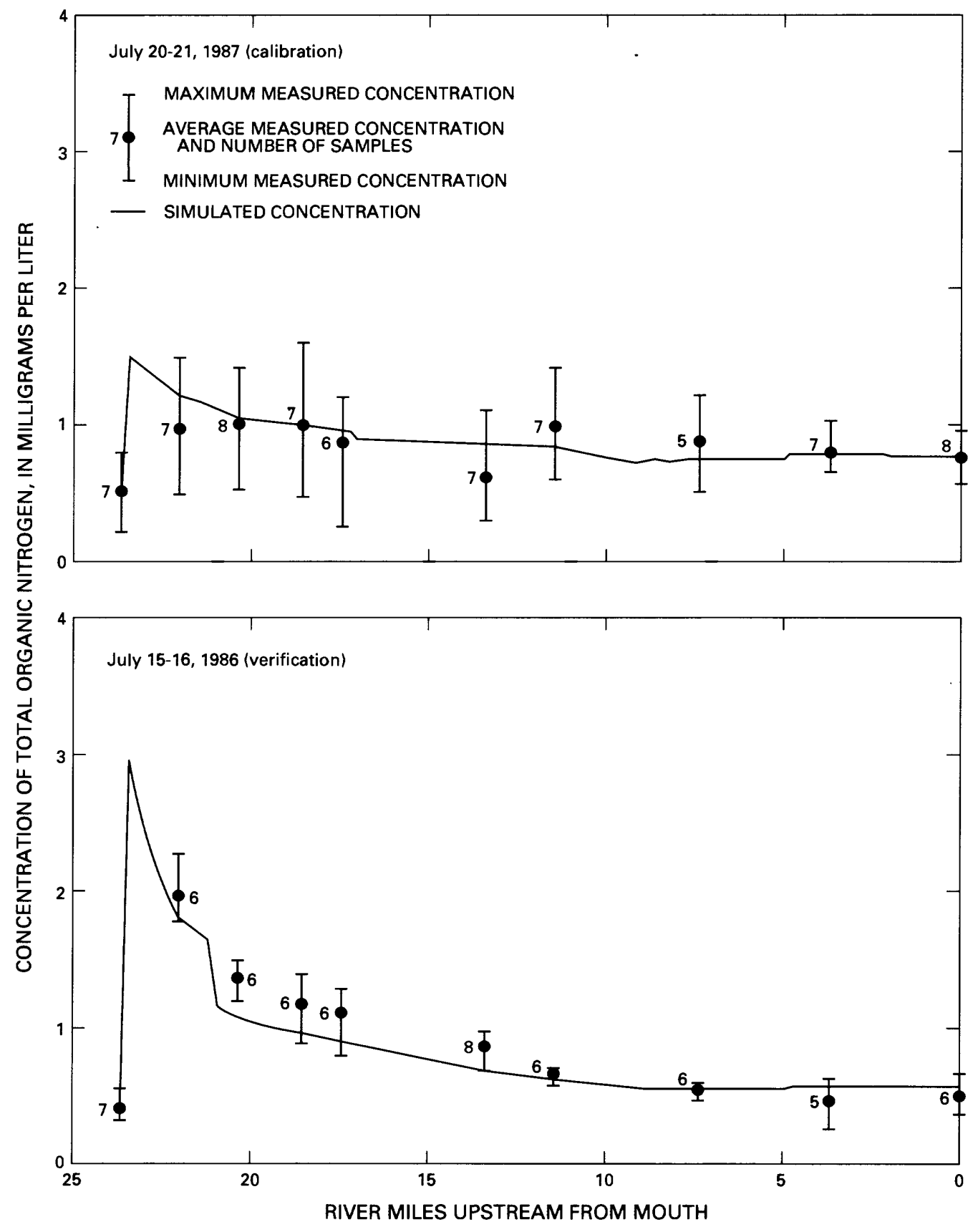

Figure 10.--Simulated and measured concentrations of total organic nitrogen for Monument Creek, July 1987 and July 1986 simulations. 


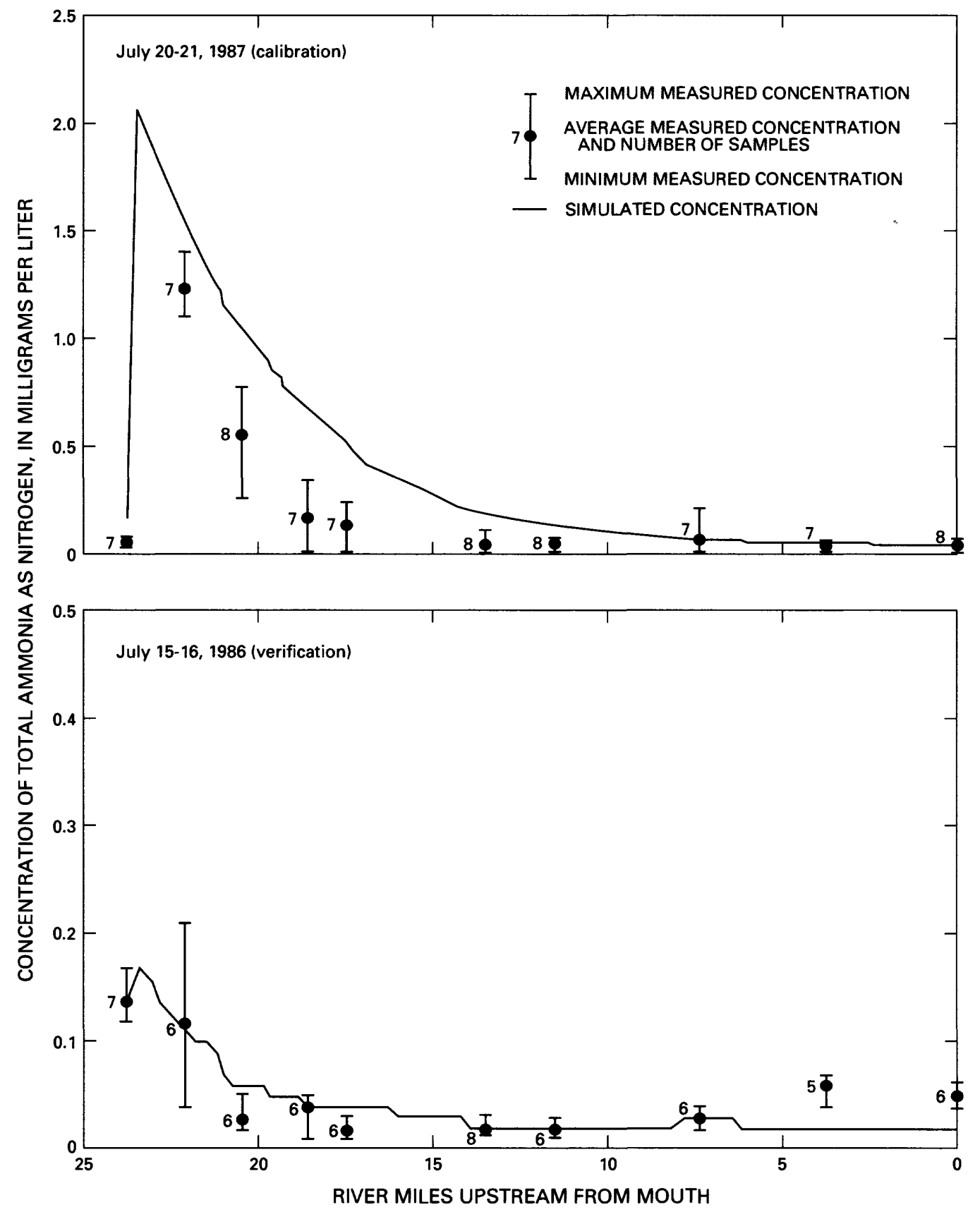

Figure 11.--Simulated and measured concentrations of total ammonia as nitrogen for Monument Creek, July 1987 and July 1986 simulations. 


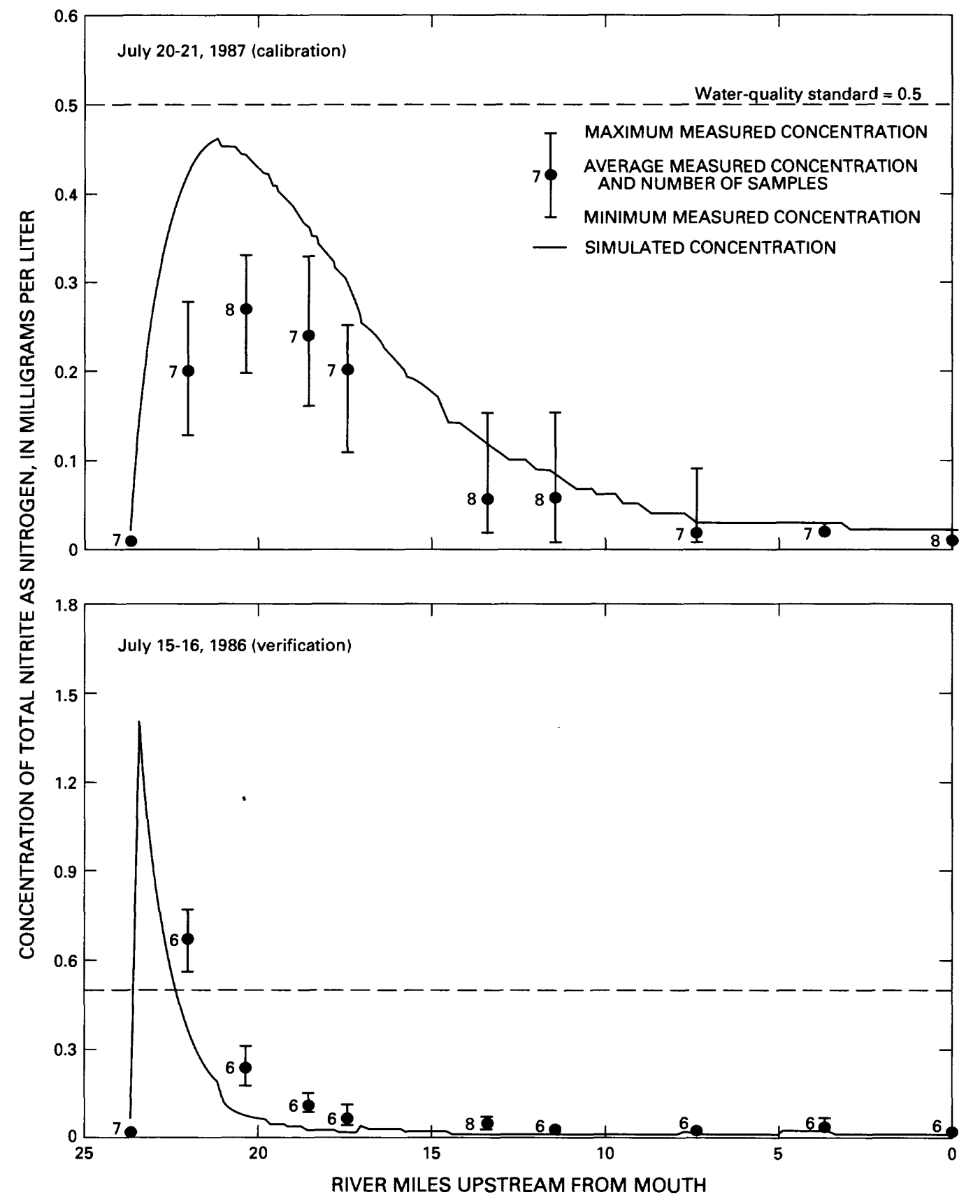

Figure 12.--Simulated and measured concentrations of total nitrite as nitrogen for Monument Creek, July 1987 and July 1986 simulations. 
Because the simulated and measured concentrations of nitrate generally were less than $2.5 \mathrm{mg} / \mathrm{L}$ and the trends are similar (fig. 13), the calibration and verification were accepted even though the quantitative criterion was not met (table 15). Some of the differences between simulated and measured nitrate concentration (fig. 13), especially for the verification simulation, could be attributed partly to errors in the estimated concentration of nitrate in ground-water discharge. A decay coefficient for nitrate of 1.0 days $^{-1}$ was determined during calibration for six subreaches (table 12). The waterquality standard of $10 \mathrm{mg} / \mathrm{L}$ for nitrate concentration was not exceeded (fig. 13).

Calibration and verification for 5-day CBOD also were accepted for Monument Creek even though the quantitive criterion was not met (table 15) because the simulated and measured concentrations generally were less than $6.0 \mathrm{mg} / \mathrm{L}$ and the trends are similar (fig. 14). The deoxygenation rate coefficient of 0.2 days $^{-1}$ (table 12) derived from the 5-day CBOD analyses was used for Monument Creek.

The trends of simulated and measured DO are not similar for about 7 river miles downstream from the Tri-Lakes WWTF for the calibration simulation (fig. 15). The error in simulated Do partly may be attributed to the incorrect simulations of ammonia and nitrite; DO is consumed by the conversions of ammonia to nitrite and nitrite to nitrate. Because the differences in simulated and average measured DO generally were less than $1.0 \mathrm{mg} / \mathrm{L}$ for the sites not meeting the quantitative criterion (fig. 15; table 15), not accepting the calibration for DO was considered questionable. Concentration of DO always was greater than the water-quality standard of $5.0 \mathrm{mg} / \mathrm{L}$ (fig. 15).

\section{Upper Fountain Creek}

As described in the "Estimated Discharges" section of this report, Fountain Creek is an ephemeral stream upstream from about river mile 66.52 and had a zero-discharge subreach between about river miles 67.27 and 66.52 during the diel-sampling periods. The measured water-quality characteristics of Fountain Creek upstream from the zero-discharge subreach were very different from those measured downstream from the zero-discharge subreach (Kuhn and Ortiz, 1989, p. 28-31). Because of the zero-discharge subreach and the disjunction in water quality, Fountain Creek upstream from river mile 67.27 was simulated separately from the rest of upper Fountain Creek (downstream from river mile 66.52 ).

Reaction of organic nitrogen, ammonia, nitrite, and 5-day CBOD in Fountain Creek between the Woodland Park WWTF (site FT68.10) and site F67.28 (fig. 2, area C) was evident in the simulations. However, because only two sites (F67.76 and F67.28) were available for comparison of simulated and measured concentrations, the reaction coefficients listed for Fountain Creek upstream from river mile 67.27 (table 12, subreaches 18-21) are inconclusive. Simulated results for these subreaches are shown in the subsequent figures of this report section, but sites $\mathrm{F} 67.76$ and $\mathrm{F} 67.28$ were not included in the acceptability criteria analysis for upper Fountain Creek (table 15). 


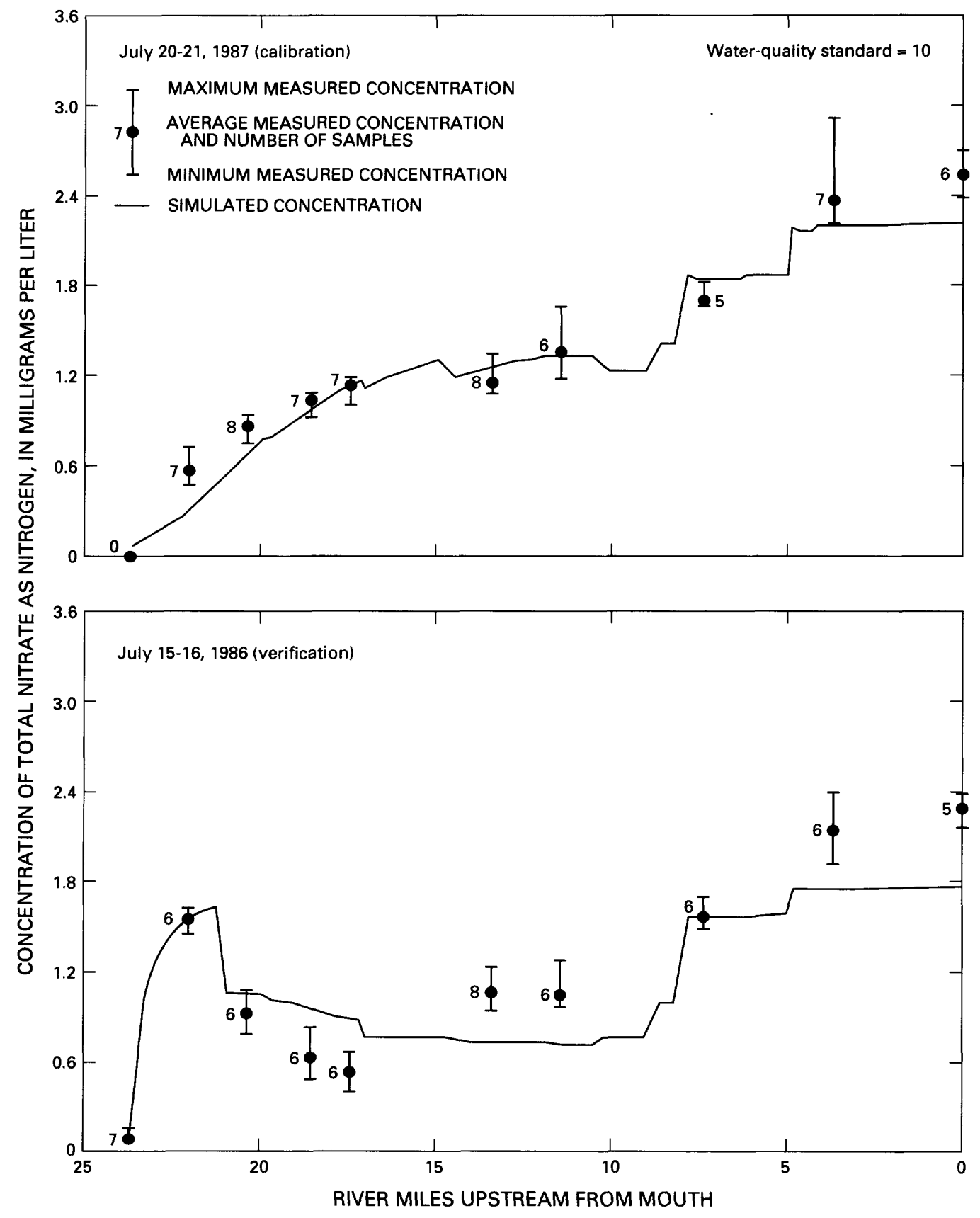

Figure 13.--Simulated and measured concentrations of total nitrate as nitrogen for Monument Creek, July 1987 and July 1986 simulations. 


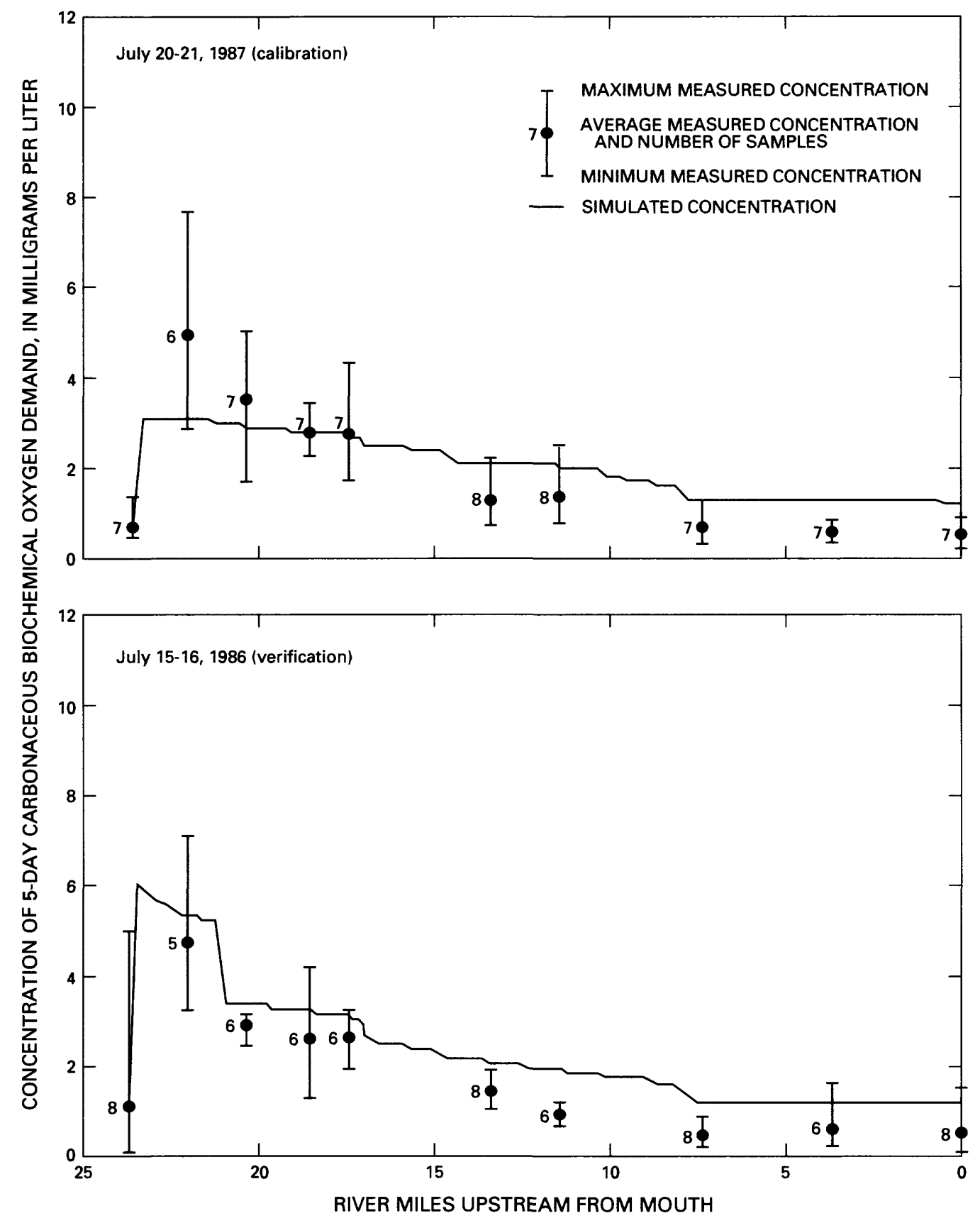

Figure 14.--Simulated and measured concentrations of 5-day carbonaceous biochemical oxygen demand for Monument Creek, July 1987 and July 1986 simulations. 


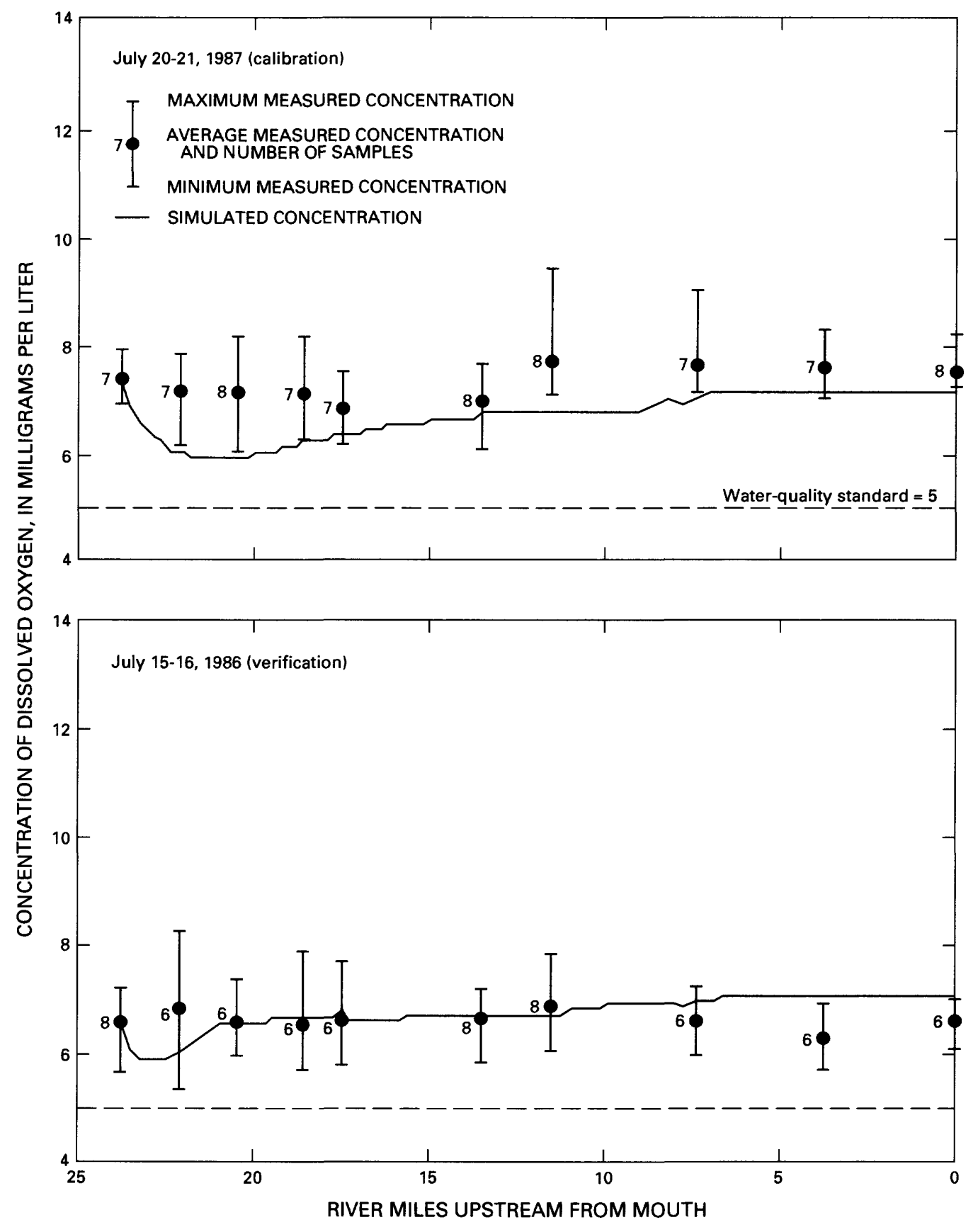

Figure 15.--Simulated and measured concentrations of dissolved oxygen for Monument Creek, July 1987 and July 1986 simulations. 
Downstream from site F66.52, measured concentrations of ammonia, nitrite, and 5-day $\mathrm{CBOD}$ were small (table 9), providing little opportunity to calibrate and verify the reaction coefficients for these constituents. Although concentrations of organic nitrogen were larger than those of ammonia, nitrite, and 5-day CBOD (table 9), the small forward reaction coefficients determined for organic nitrogen for upper Fountain Creek (table 12) indicated little nitrification of organic nitrogen. As a result, simulated concentrations of waterquality constituents for upper Fountain Creek downstream from river mile 66.52 were not sensitive to the reaction coefficients listed in table 12 .

The calibration and verification simulations for upper Fountain Creek downstream from river mile 66.52 were acceptable for most water-quality constituents. However, the reaction coefficients determined for upper Fountain Creek (table 12) can be applied confidently only to a discharge condition similar to that in the calibration and verification simulations. This condition consists of zero discharge in Fountain Creek between about river miles 67.27 and 66.52 and no wastewater inflows between river miles 66.52 and 50.61 .

Acceptable calibration and verification of organic nitrogen were achieved for upper Fountain Creek (fig. 16; table 15) by using uniform forward reaction coefficients of 0.1 days $^{-1}$ (table 12 ). Upstream from river mile 67.27

measured concentrations of organic nitrogen were large owing to the large concentrations of organic nitrogen in wastewater discharged by the Woodland Park and Woodland Acres WWTF's (table 9, sites FT68.10 and FT68.09); this also applies to subsequent discussions for ammonia, nitrite, and 5-day CBOD.

Downstream from the zero-discharge subreach (fig. 16), measured concentrations of organic nitrogen were small because neither tributary discharge nor groundwater discharge contain much organic nitrogen.

Acceptable calibration for ammonia (fig. 17; table 15) was achieved by using a uniform reaction coefficient of 4.0 days $^{-1}$ (table 12). The verification for ammonia was accepted because the concentrations of simulated and measured ammonia generally were less than $0.05 \mathrm{mg} / \mathrm{L}$ even though the quantitative acceptability criterion was not met (table 15).

The calibration for nitrite for upper Fountain Creek was acceptable (fig. 18; table 15) by using reaction coefficients of 10 days $^{-1}$ (table 12); reaction coefficients of 80 days $^{-1}$ were determined upstream from river mile 67.27 (table 12). As in the verification of ammonia, the verification for nitrite was accepted downstream from river mile 66.52 because the simulated and measured concentrations generally were less than $0.05 \mathrm{mg} / \mathrm{L}$. The waterquality standard for nitrite, $0.05 \mathrm{mg} / \mathrm{L}$, was exceeded only upstream from river mile 67.27 .

An acceptable calibration and verification for nitrate could not be achieved (fig. 19; table 15). Simulated concentrations of nitrate were consistently smaller than the measured concentrations. The larger measured concentrations probably result from a nitrate source that was not accounted for during the collection of water-quality samples. Error in the assumed concentration of nitrate in ground-water inflow also may account for the differences in simulated and measured nitrate. The water-quality standard of $10 \mathrm{mg} / \mathrm{L}$ was not exceeded by simulated or measured concentrations of nitrate (fig. 19). 


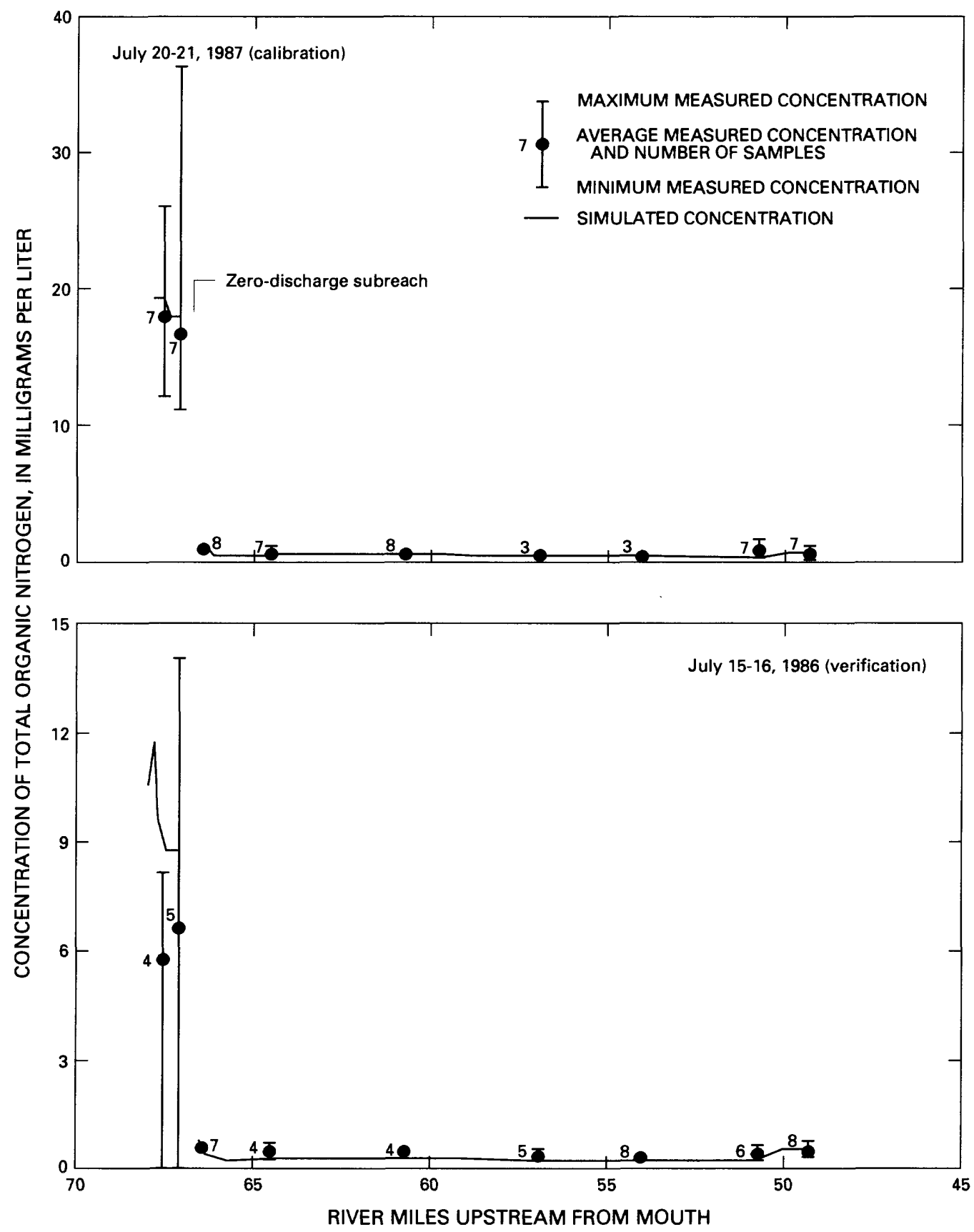

Figure 16.--Simulated and measured concentrations of total organic nitrogen for upper Fountain Creek, July 1987 and July 1986 simulations. 


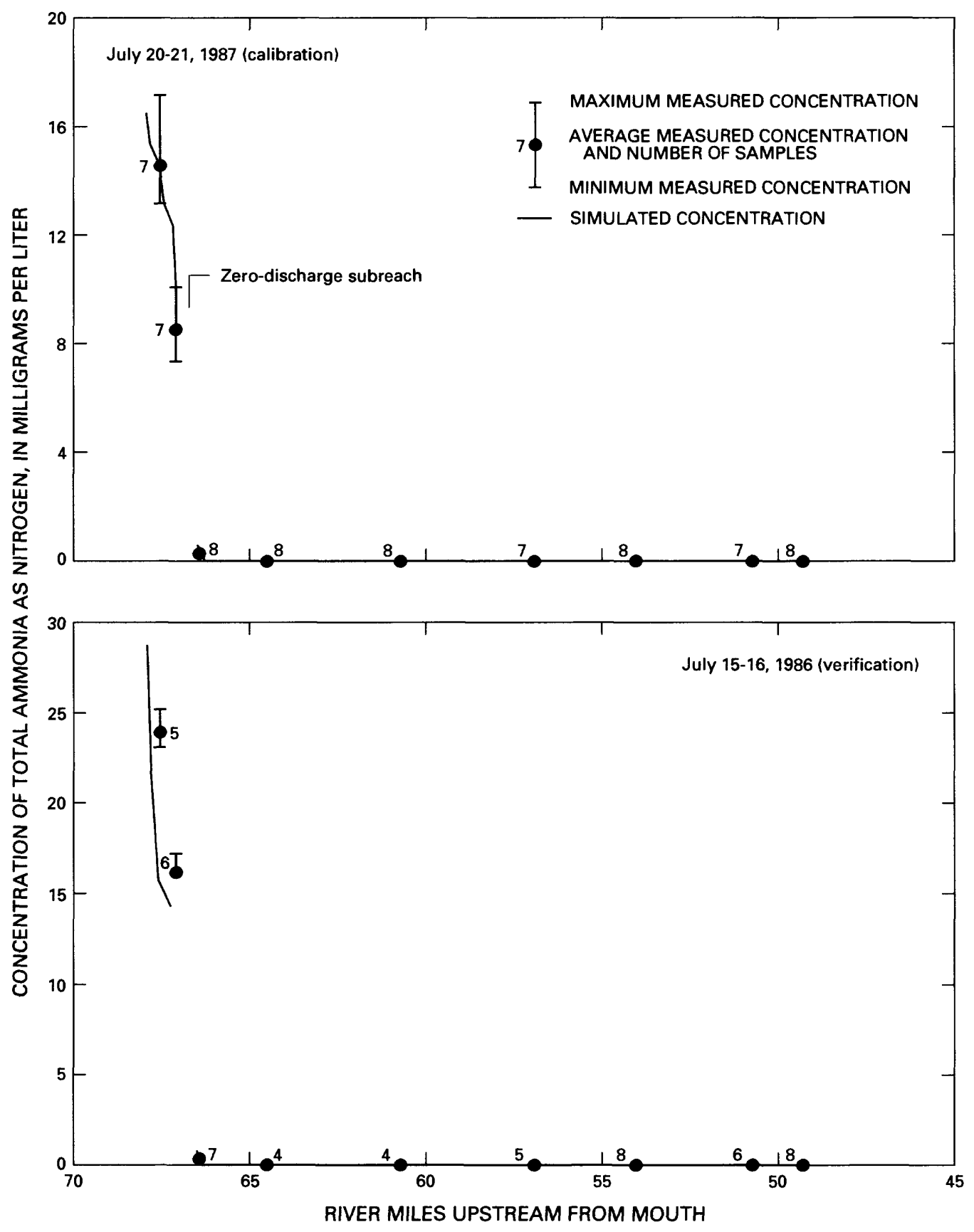

Figure 17.--Simulated and measured concentrations of total ammonia as nitrogen for upper Fountain Creek, July 1987 and July 1986 simulations. 


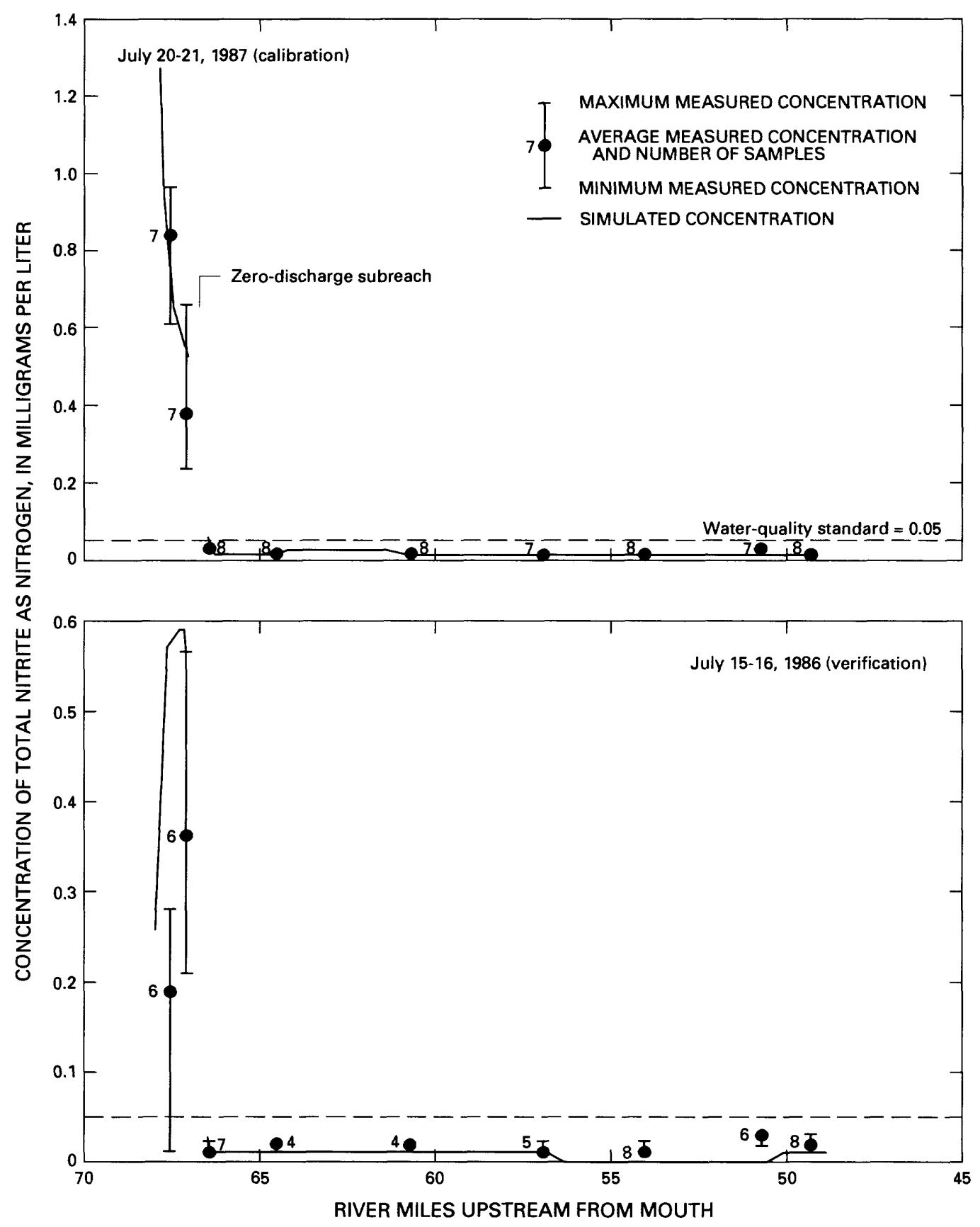

Figure 18.--Simulated and measured concentrations of total nitrite as nitrogen for upper Fountain Creek, July 1987 and July 1986 simulations. 


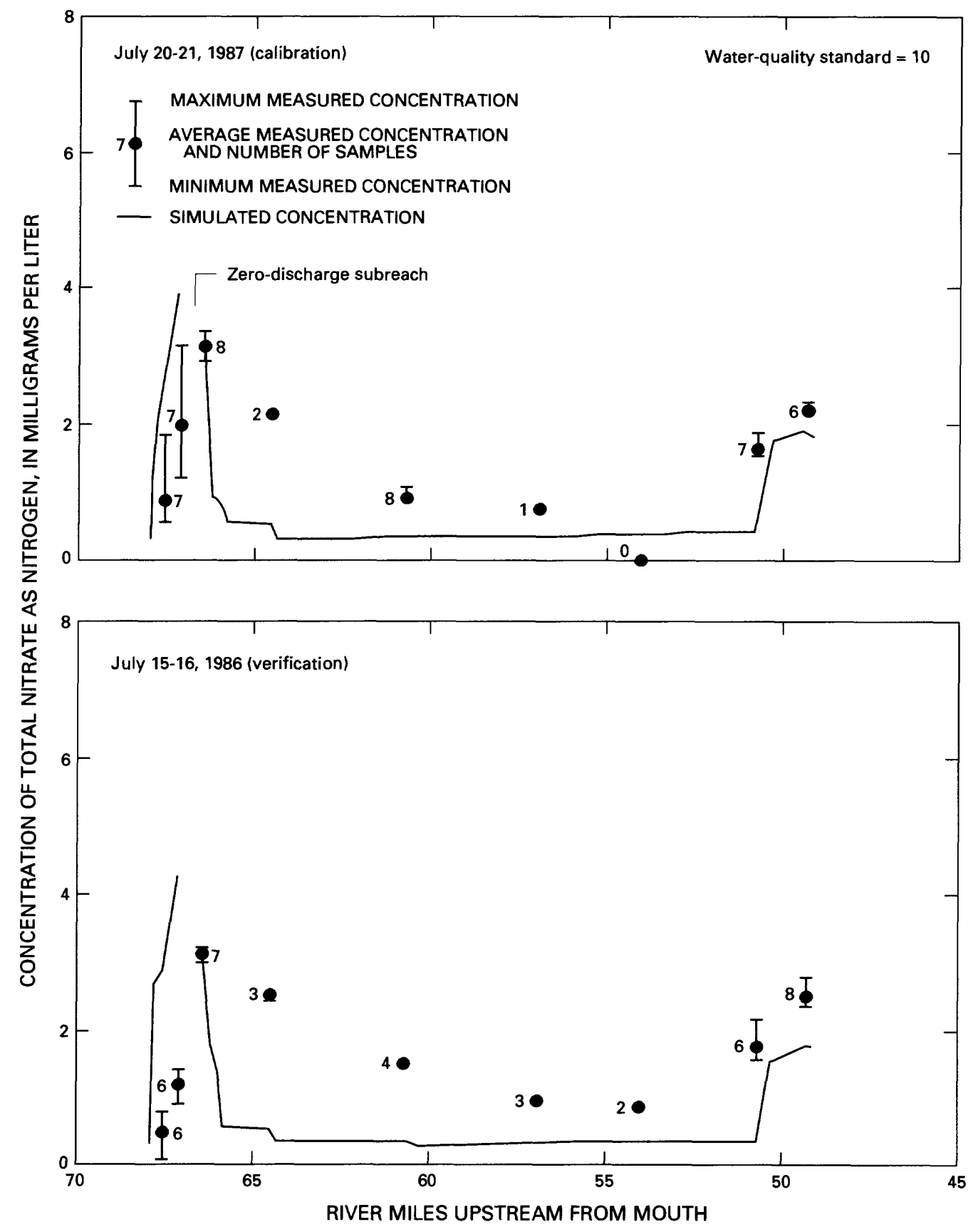

Figure 19.--Simulated and measured concentrations of total nitrate as nitrogen for upper Fountain Creek, July 1987 and July 1986 simulations. 
Acceptable calibration and verification for 5-day $C B O D$ were achieved for upper Fountain Creek (fig. 20; table 15). A uniform deoxygenation-rate coefficient of 0.4 days $^{-1}$ (table 12) based on the laboratory analyses of 5-day CBOD was used.

Simulated Do met the quantitative acceptance criterion for the calibration but not for the verification (fig. 21; table 15). However, because the differences in simulated and average measured concentrations of DO generally were less than $1.0 \mathrm{mg} / \mathrm{L}$ at sites that did not meet the criterion, lack of accepting the verification for DO was considered questionable. Measured and simulated concentrations of DO generally were larger than the water-quality standard of $5.0 \mathrm{mg} / \mathrm{L}$ (fig. 21).

\section{Middle Fountain Creek}

Acceptable calibration and verification of organic nitrogen were achieved for middle Fountain Creek (fig. 22; table 15); a uniform forward reaction coefficient of 0.1 days $^{-1}$ was determined (table 12). The increase in concentration of organic nitrogen at river mile 48.67 results from the large volume of discharge by the Colorado Springs WWTF, which contains larger concentrations of organic nitrogen (table 9) than those in Fountain Creek upstream from the WWTF. The large variation in measured organic nitrogen at most sites (fig. 22) primarily is the result of variation in organic nitrogen concentration in discharge from the different WWTF's.

The reasons why the measured concentrations of organic nitrogen are smaller and less variable downstream from about river mile 35 for the calibration data set are not known. The measured concentrations of ammonia and nitrite indicate a similar condition. The large volume of diversion at site FT39.08 (table 9) substantially decreased discharge in Fountain Creek (fig. 4); this decrease in discharge may have resulted in increased rates of nitrification. Because the volume of diversion at this site is variable and may not always be as large as during the July 1987 sampling period, the reaction coefficients (except the nitrate decay coefficient) used for the subreaches downstream from about river mile 35 are consistent with those for other subreaches in middle Fountain Creek (table 12).

Acceptable calibration and verification of ammonia also were achieved (fig. 23; table 15). The calibration was accepted even though the quantitative criterion was not met because (1) the criterion was met for sites in the upstream reaches of middle Fountain Creek; (2) the criterion largely was not met for sites in the downstream reaches because of the anomalous decrease in measured concentrations downstream from about river mile 35 (see previous paragraph); and (3) the trends for simulated and measured concentrations are similar. The increase in concentration of ammonia at river mile 48.67 is larger than that for organic nitrogen because the concentration of ammonia in discharge from the Colorado Springs WWTF is larger than the concentration of organic nitrogen (table 9 ). 


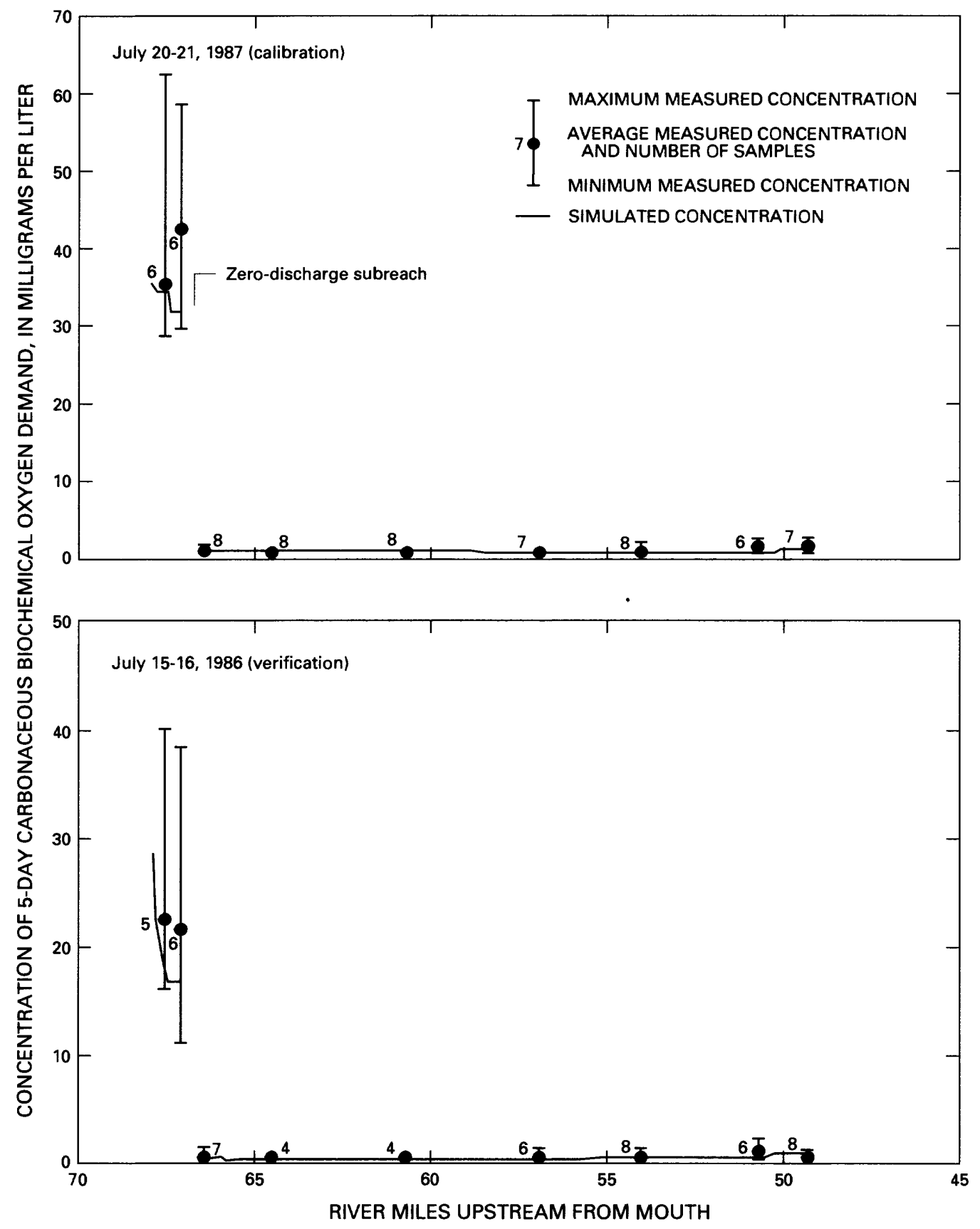

Figure 20.--Simulated and measured concentrations of 5-day carbonaceous biochemical oxygen demand for upper Fountain Creek, July 1987 and July 1986 simulations. 


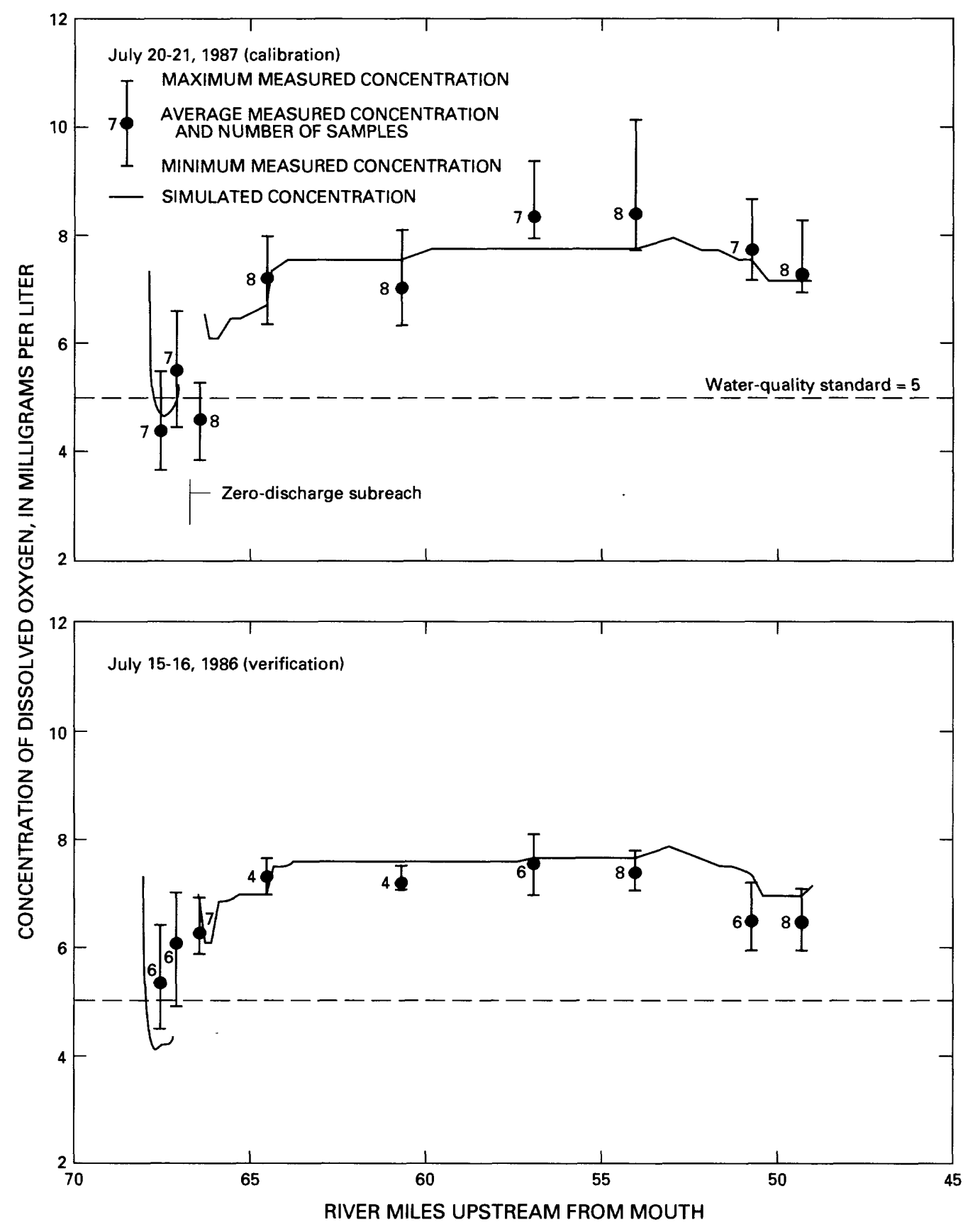

Figure 21.--Simulated and measured concentrations of dissolved oxygen for upper Fountain Creek, July 1987 and July 1986 simulations. 


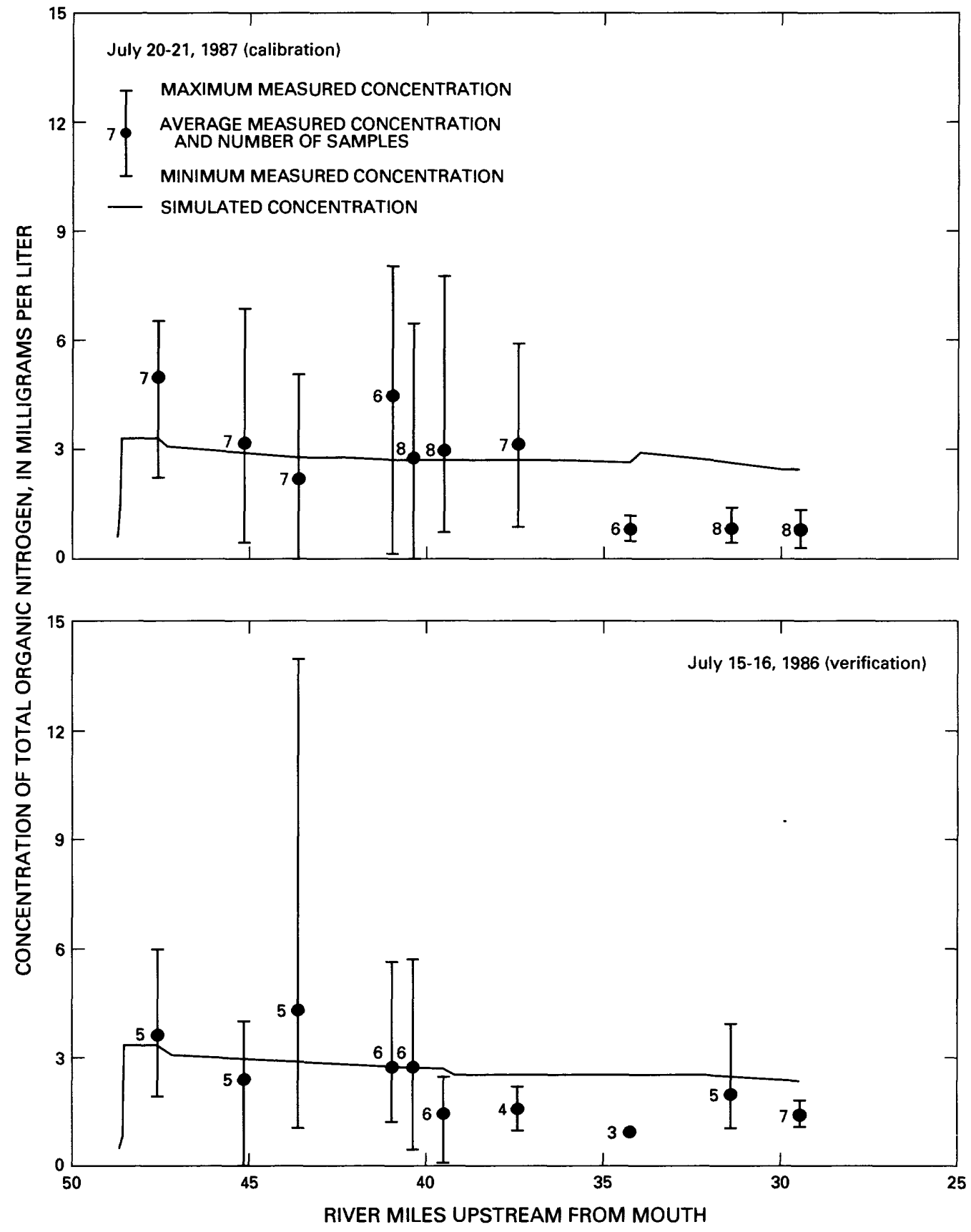

Figure 22.--Simulated and measured concentrations of total organic nitrogen for middle Fountain Creek, July 1987 and July 1986 simulations. 


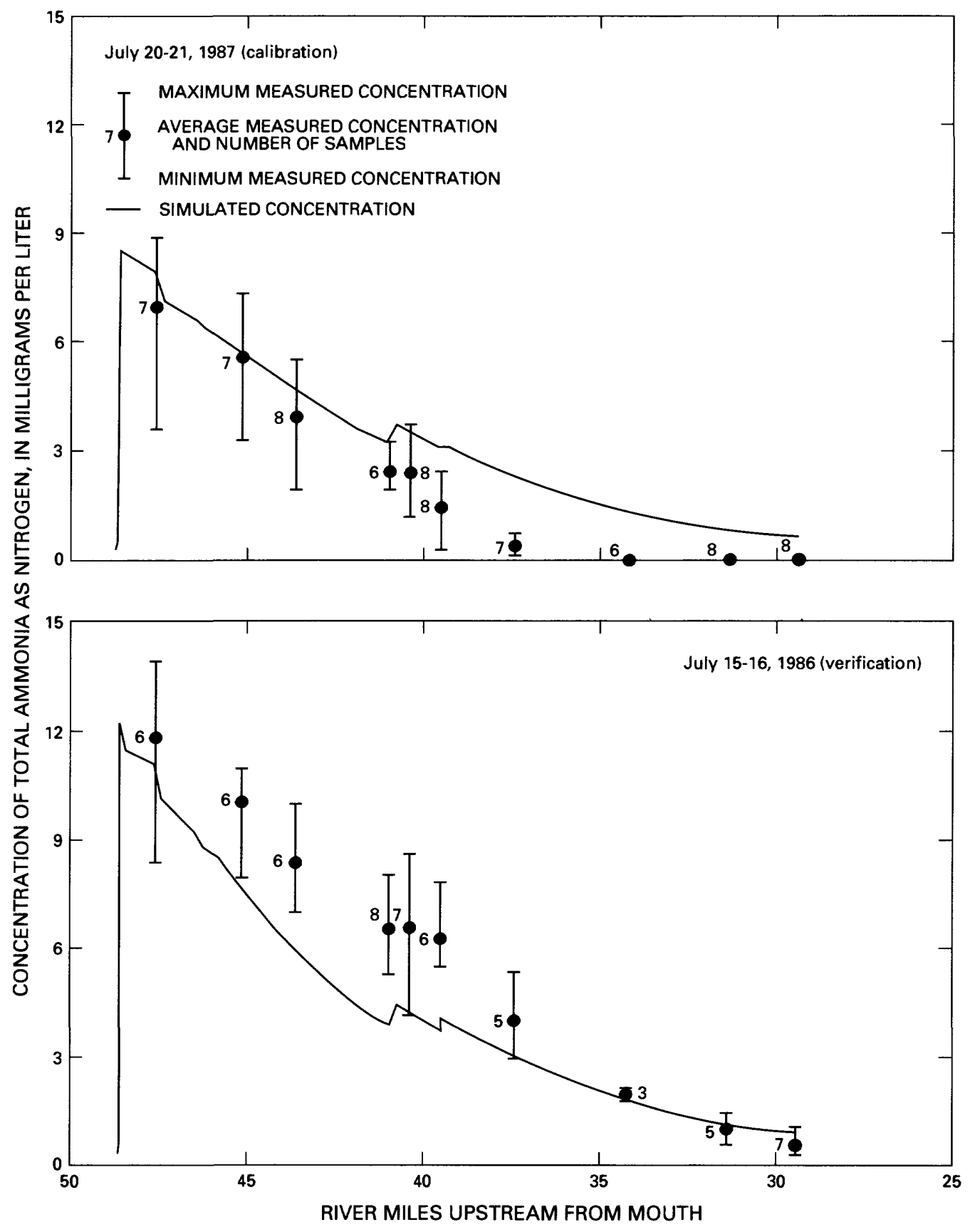

Figure 23.--Simulated and measured concentrations of total ammonia as nitrogen for middle Fountain Creek, July 1987 and July 1986 simulations. 
A uniform forward reaction coefficient of 4.0 days $^{-1}$ was determined for all subreaches, except three (subreaches 37,38 , and 39 ), downstream from river mile 48.67 ( $t a b l e ~ 12)$. The smaller reaction coefficients for ammonia (except for subreach 37 for the alternate method) probably were needed for those subreaches because discharge from the Colorado Springs WWTF is much larger than discharge in Fountain Creek (fig. 5). When the alternate simulation method was used, a much larger reaction coefficient was determined for subreach 37; the reasons have been described previously in the "Reaction Coefficients" and "Method of Simulating Colorado Springs Wastewater-Treatment Facility" sections of this report.

Calibration of nitrite was acceptable for middle Fountain Creek; however, nitrite could not be verified (fig. 24; table 15). The larger reaction coefficient for nitrite for subreach 37 (table 12) was determined because of the alternate simulation method (see previous paragraph). The water-quality standard for nitrite, $1.0 \mathrm{mg} / \mathrm{L}$, was exceeded at seven sites in the verification simulation but only at one site in the calibration simulation (fig. 24 ).

Acceptable calibration of nitrate was achieved; however, nitrate could not be verified (fig. 25 ; table 15). Nitrate decay coefficients of 2.0 days $^{-1}$ were determined for 11 subreaches; a larger coefficient was determined for subreach 37 using the alternate simulation method (table 12). Possible reasons for the large difference between simulated and measured concentrations of nitrate for the verification simulation (fig. 25) include: (1) Conversion of more nitrite to nitrate in the simulation than that which actually occurred in Fountain Creek (fig. 24), and (2) inaccuracies in simulation of groundwater discharge and recharge. Simulated and measured concentrations of nitrate were considerably smaller than the water-quality standard of $10 \mathrm{mg} / \mathrm{L}$ (fig. 25).

Calibration and verification for 5-day CBOD was acceptable for middle Fountain Creek (fig. 26; table 15). A deoxygenation-rate coefficient of 0.1 days $^{-1}$ (except for 0.4 days $^{-1}$ for subreach 36 ) based on the laboratory analyses of 5-day CBOD was used (table 12).

The quantitative criterion for calibration was not met for DO (table 15); however, the trends of simulated and average measured DO are similar and the differences between simulated and average measured concentrations usually are no larger than $1.0 \mathrm{mg} / \mathrm{L}$ (fig. 27). Therefore, not accepting the calibration for DO was considered questionable (table 15). For the verification simulation, the trends are dissimilar and differences between simulated and average measured concentrations are larger than for the calibration simulation (fig. 27). A decrease in simulated concentrations of DO is evident between about river miles 45 and 40 for the calibration and verification simulations. This is about the same location of maximum concentration of nitrite (fig. 24); concentrations of DO generally are less than the water-quality standard of $5.0 \mathrm{mg} / \mathrm{L}$ in this location (fig. 27). Simulated DO also decreases between river miles 48.67 and 48.42 (fig. 27); the decrease partly results from the large oxygen-demanding processes immediately downstream from the Colorado Springs WWTF and partly results from inaccuracy in the alternate simulation method. The decrease in $D O$ is about 1 to $2 \mathrm{mg} / \mathrm{L}$ less when using the actual simulation method. 


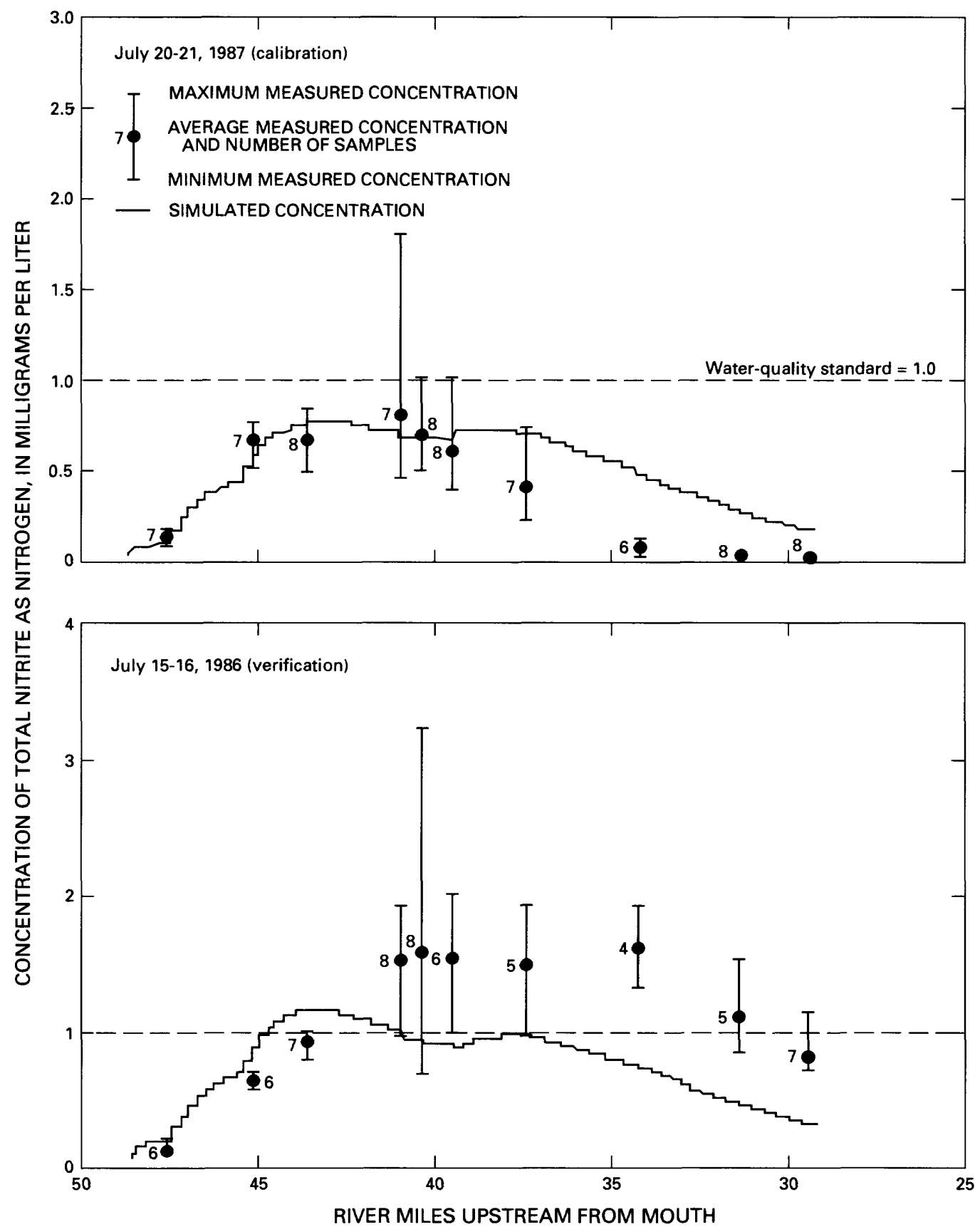

Figure 24,--Simulated and measured concentrations of total nitrite as nitrogen for middle Fountain Creek, July 1987 and July 1986 simulations. 


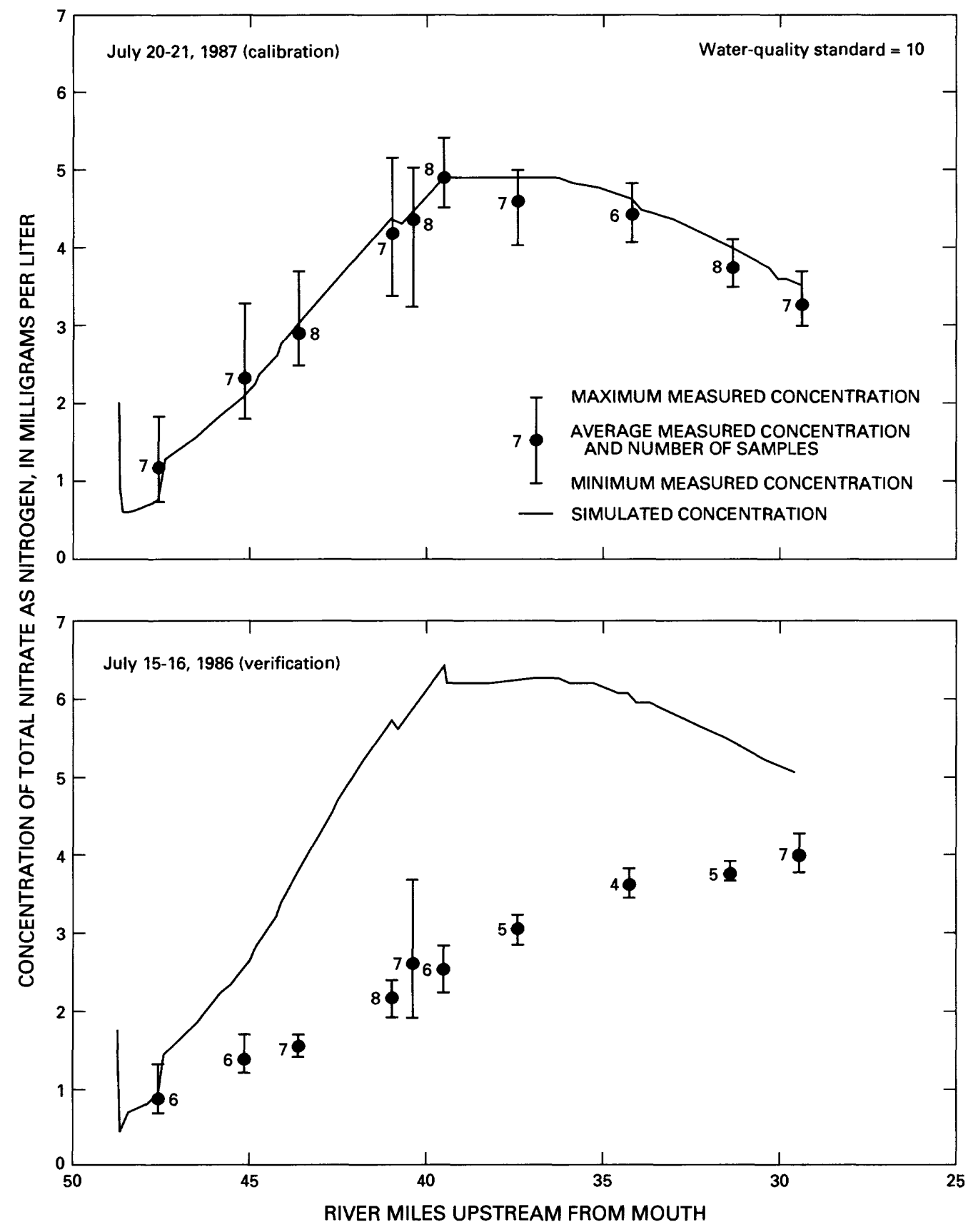

Figure 25.--Simulated and measured concentrations of total nitrate as nitrogen for middle Fountain Creek, July 1987 and July 1986 simulations. 


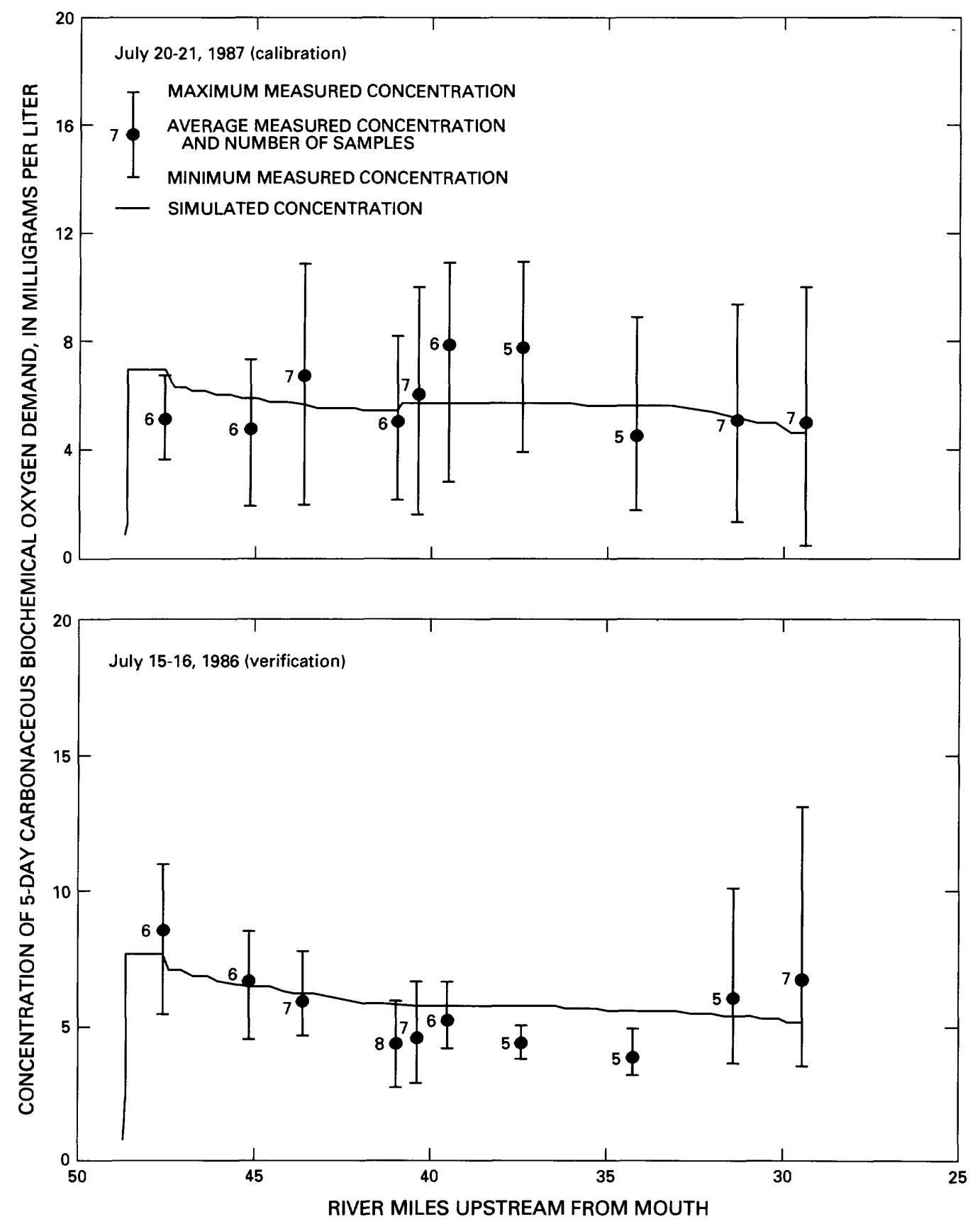

Figure 26.--Simulated and measured concentrations of 5-day carbonaceous biochemical oxygen demand for middle Fountain Creek, July 1987 and July 1986 simulations. 


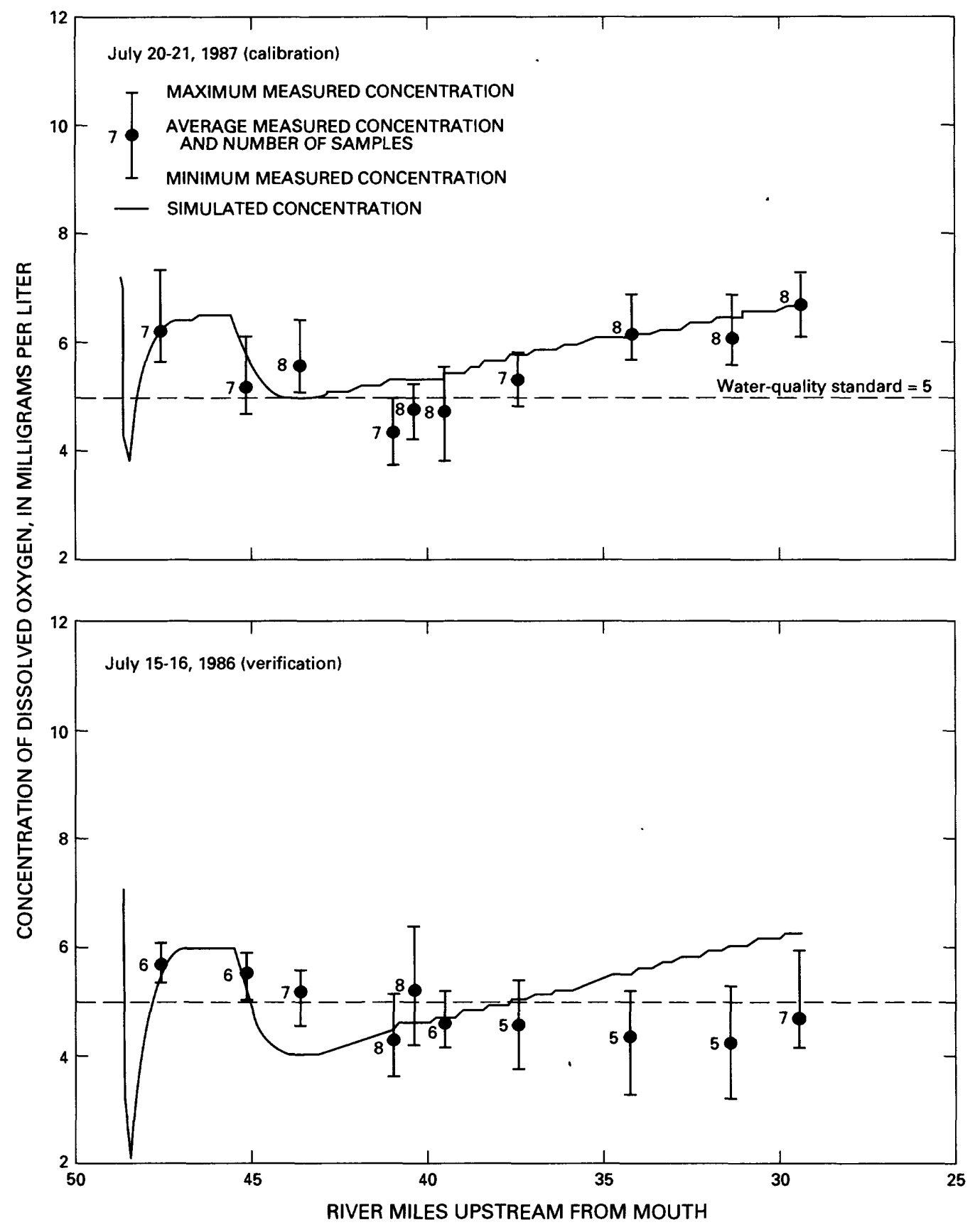

Figure 27.--Simulated and measured concentrations of dissolved oxygen for middle Fountain Creek, July 1987 and July 1986 simulations. 


\section{Results for Winter Stream Reach}

The winter stream reach was calibrated by using the December 1986 waterquality and discharge data set and was verified by using the February 1987 data set. Results for the calibration and verification simulations are presented separately for the middle Fountain Creek and lower Fountain Creek stream sections (table 16). Note that the middle Fountain Creek section extends to river mile 25.33 for the winter stream reach; this stream section ended at river mile 29.47 for the summer stream reach (tables 4 and 5 ). Also, although site $F 25.25$ (table 2; fig. 2, area F) is shown in subsequent figures showing the calibration and verification results for middle Fountain Creek, this site is a part of the lower Fountain Creek stream section. The calibration and verification results for lower Fountain Creek listed in table 16 and the subsequent discussions in the "Lower Fountain Creek" section include site F25.25; the results (table 16) and discussions for "Middle Fountain Creek" do not include this site.

\section{Middle Fountain Creek}

Acceptable calibration and verification of organic nitrogen were achieved (fig. 28; table 16); a uniform forward reaction coefficient of 0.1 days $^{-1}$ was determined (table 13). Measured concentrations of organic nitrogen vary substantially at individual sites; this also was noted for calibration and verification of the summer stream reach (fig. 22).

Ammonia was calibrated and verified acceptably for middle Fountain Creek (fig. 29; table 16). Between river miles 49.34 and 29.47 , the forward reaction coefficients for ammonia (table 13) are the same as those determined in calibration of the summer stream reach, except for subreach 37 (table 12). Reaction coefficients for the alternate and actual simulation methods are the same for the winter stream reach (see "Reaction Coefficients" and "Method of Simulating Colorado Springs Wastewater-Treatment Facility" sections of this report).

Simulated nitrite for middle Fountain Creek for the calibration simulation did not meet the quantitative acceptability criterion; however, the calibration was accepted because the simulated and measured concentrations were less than $0.2 \mathrm{mg} / \mathrm{L}$ (table 16; fig. 30). The verification simulation met the criterion; concentrations generally were about $0.05 \mathrm{mg} / \mathrm{L}$ larger than for the calibration. Note that concentrations of nitrite in middle Fountain Creek for the winter simulations are about one-tenth of those for the summer simulations (figs. 24 and 30 ). The water-quality standard for nitrite of $1.0 \mathrm{mg} / \mathrm{L}$ was not exceeded in the winter stream reach simulations (fig. 30).

Forward reaction coefficients for conversion of nitrite to nitrate determined during calibration for the winter stream reach (table 13) are substantially larger than those for the summer stream reach (table 12). The reasons why the large reaction coefficients were needed are not known. The need for the larger reaction coefficients partly may be the result of possible error in the temperature-correction equation for stream temperatures less than about 10-15 ${ }^{\circ} \mathrm{C}$ (Bauer and others, 1979, p. 15; Bowie and others, 1985, p. 163-166) or partly may be the result of stream processes in Fountain Creek that are not accounted for in the model reaction kinetics. 


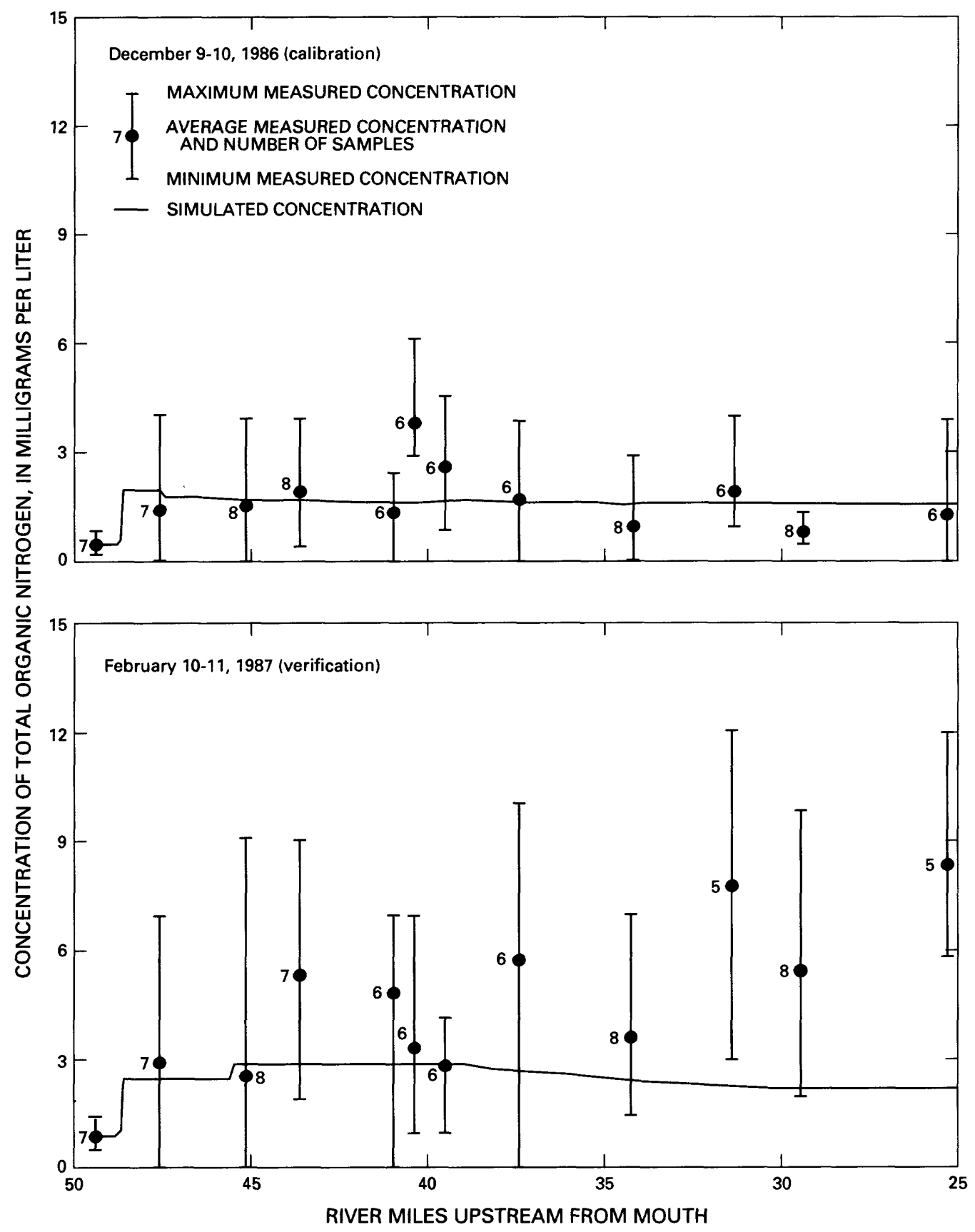

Figure 28.--Simulated and measured concentrations of total organic nitrogen for middle Fountain Creek, December 1986 and February 1987 simulations. 


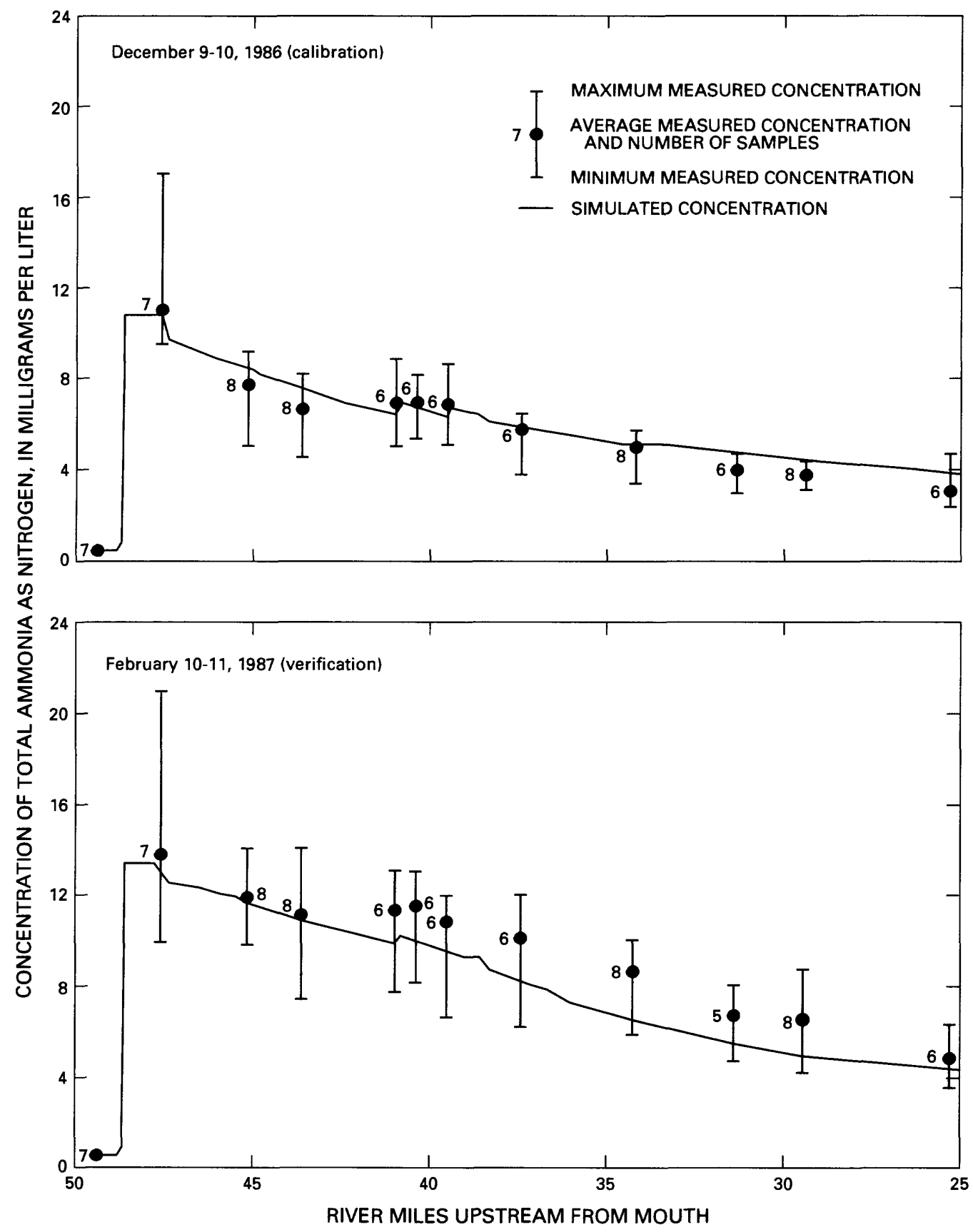

Figure 29.--Simulated and measured concentrations of total ammonia as nitrogen for middle Fountain Creek, December 1986 and February 1987 simulations. 


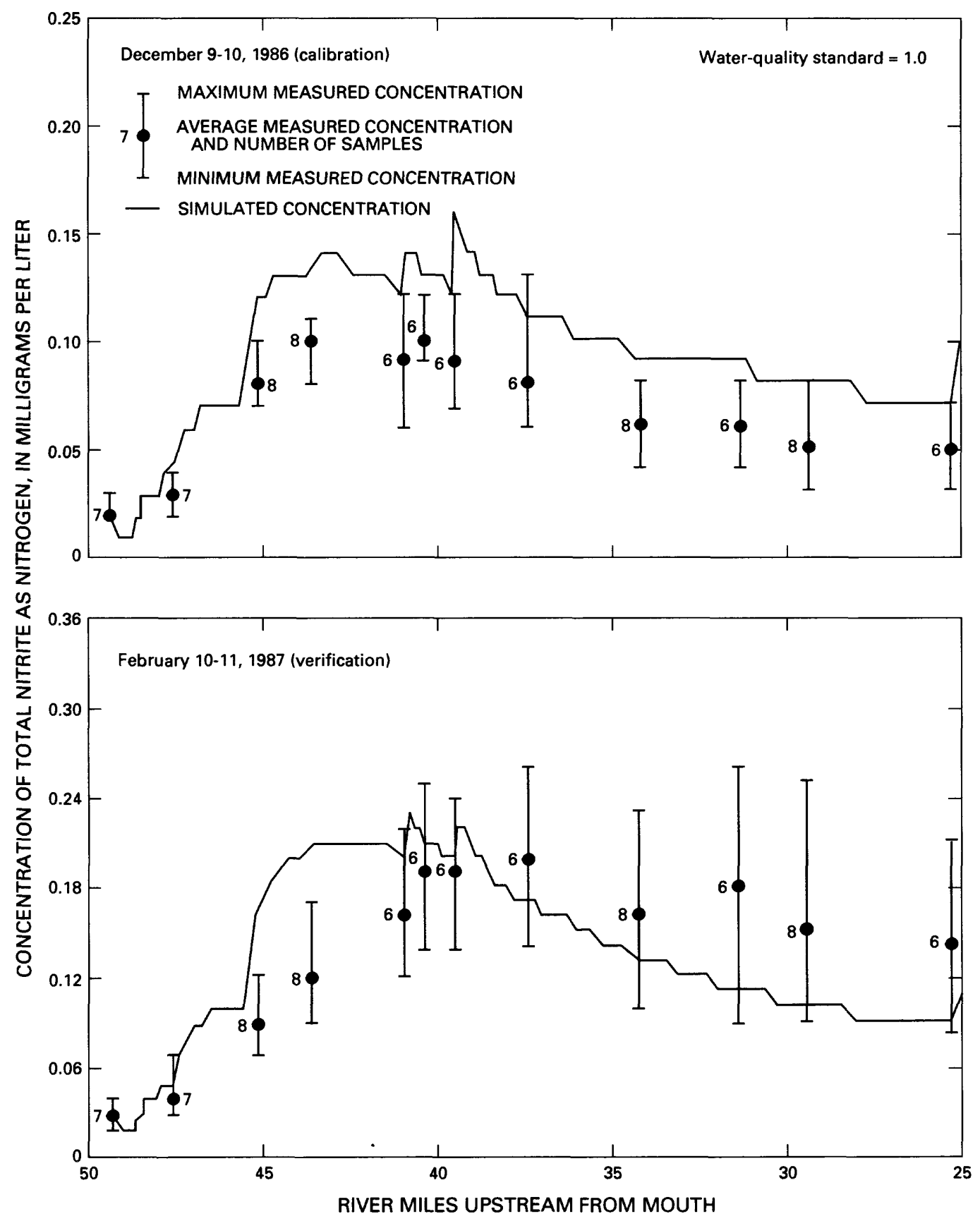

Figure 30.--Simulated and measured concentrations of total nitrite as nitrogen for middle Fountain Creek, December 1986 and February 1987 simulations. 
Decay coefficients for nitrate determined for middle Fountain Creek during calibration ranged from 3.0 to 10 days $^{-1}$ (table 13). Acceptable calibration and verification of nitrate (fig. 31 ; table 16 ) were achieved by using these decay coefficients. Concentration of nitrate in wastewater discharged by the Colorado Springs WWTF is small (table 10, site FT48.67), diluting the larger concentrations in Fountain Creek at the point of discharge (fig. 31, river mile 48.67). Primarily as a result of nitrification and ground-water discharge, concentration of nitrate increases downstream.

Acceptable calibrations and verifications of 5-day CBOD and DO were achieved (figs. 32 and 33 ; table 16). The deoxygenation rate coefficients used for 5-day CBOD (table 13) are larger than those used for the summer conditions (table 12). Concentrations of DO are larger for the winter simulations (fig. 33) than for the summer simulations (fig. 27) because of the larger DO saturation concentration for colder stream temperatures and the reduced reactions of oxygen-demanding processes. There also is a decrease in concentration of $D O$ between about river miles 45 and 40 for the winter simulations; however, concentrations of DO always are greater than the waterquality standard of $5.0 \mathrm{mg} / \mathrm{L}$ (fig. 33).

\section{Lower Fountain Creek}

Acceptable calibrations and verifications were achieved for nearly all water-quality constituents for lower Fountain Creek (figs. 34-39; table 16). The following exceptions to acceptance based on the quantitative criterion (table 16) may be noted:

1. Not accepting the verification for organic nitrogen was considered questionable because the trends of simulated and average measured concentrations are similar (fig. 34), and the measured concentrations at site F25.25 (fig. 28) seemed anomalously large.

2. Not accepting the calibration for ammonia was considered questionable because the trends also are similar and the concentrations generally were less than $2 \mathrm{mg} / \mathrm{L}$ (fig. 35).

3. The calibration for nitrite was accepted because simulated and measured concentrations were less than $0.2 \mathrm{mg} / \mathrm{L}$ (fig. 36).

4. The verification for nitrate was accepted because the trends are similar and the difference between simulated and average measured concentrations generally were no larger than $1 \mathrm{mg} / \mathrm{L}$ (fig. 37).

5. Not accepting the verification for 5-day CBOD was considered questionable because of the similarity in trend, because the average measured concentrations generally were less than $6 \mathrm{mg} / \mathrm{L}$, and because the differences between the simulated and average measured concentrations generally were less than $1.5 \mathrm{mg} / \mathrm{L}$ ( fig. 38).

6. The calibration for DO was accepted because most of the DO measurements exceeded saturation (Kuhn and Ortiz, 1989, p. 60-64), and the model cannot calculate concentration of DO larger than saturation. 


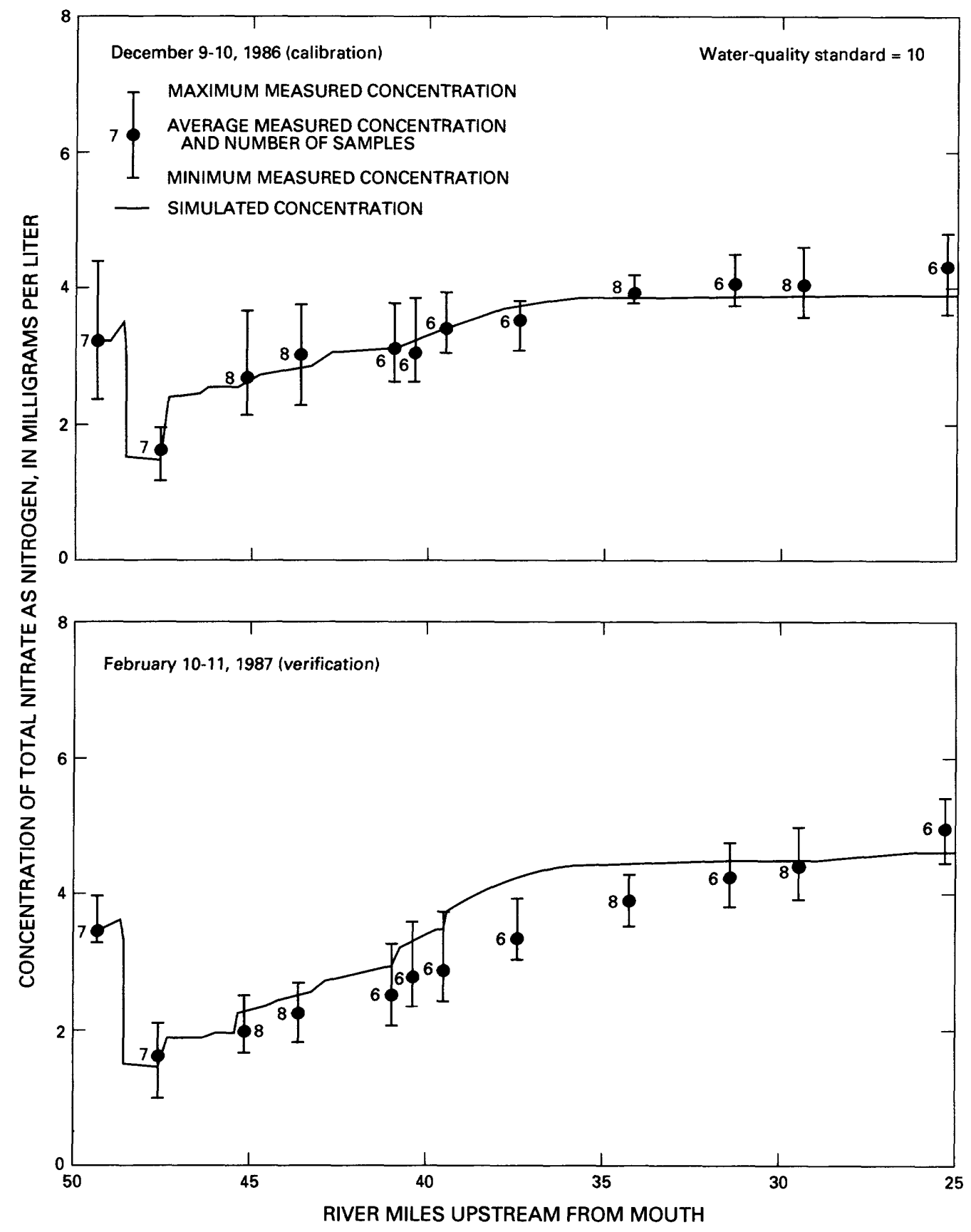

Figure 31.--Simulated and measured concentrations of total nitrate as nitrogen for middle Fountain Creek, December 1986 and February 1987 simulations. 


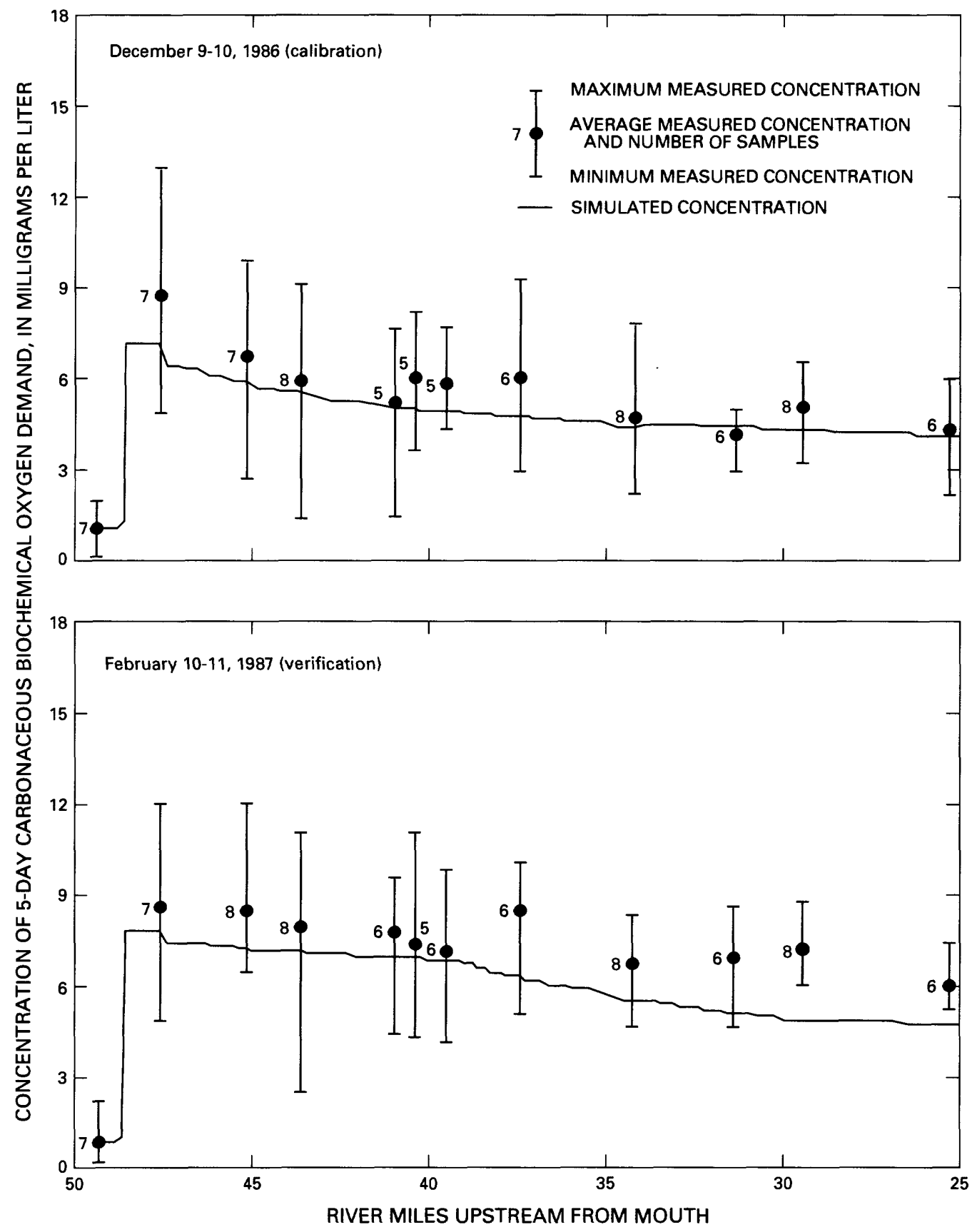

Figure 32.--Simulated and measured concentrations of 5-day carbonaceous biochemical oxygen demand for middle Fountain Creek, December 1986 and February 1987 simulations. 


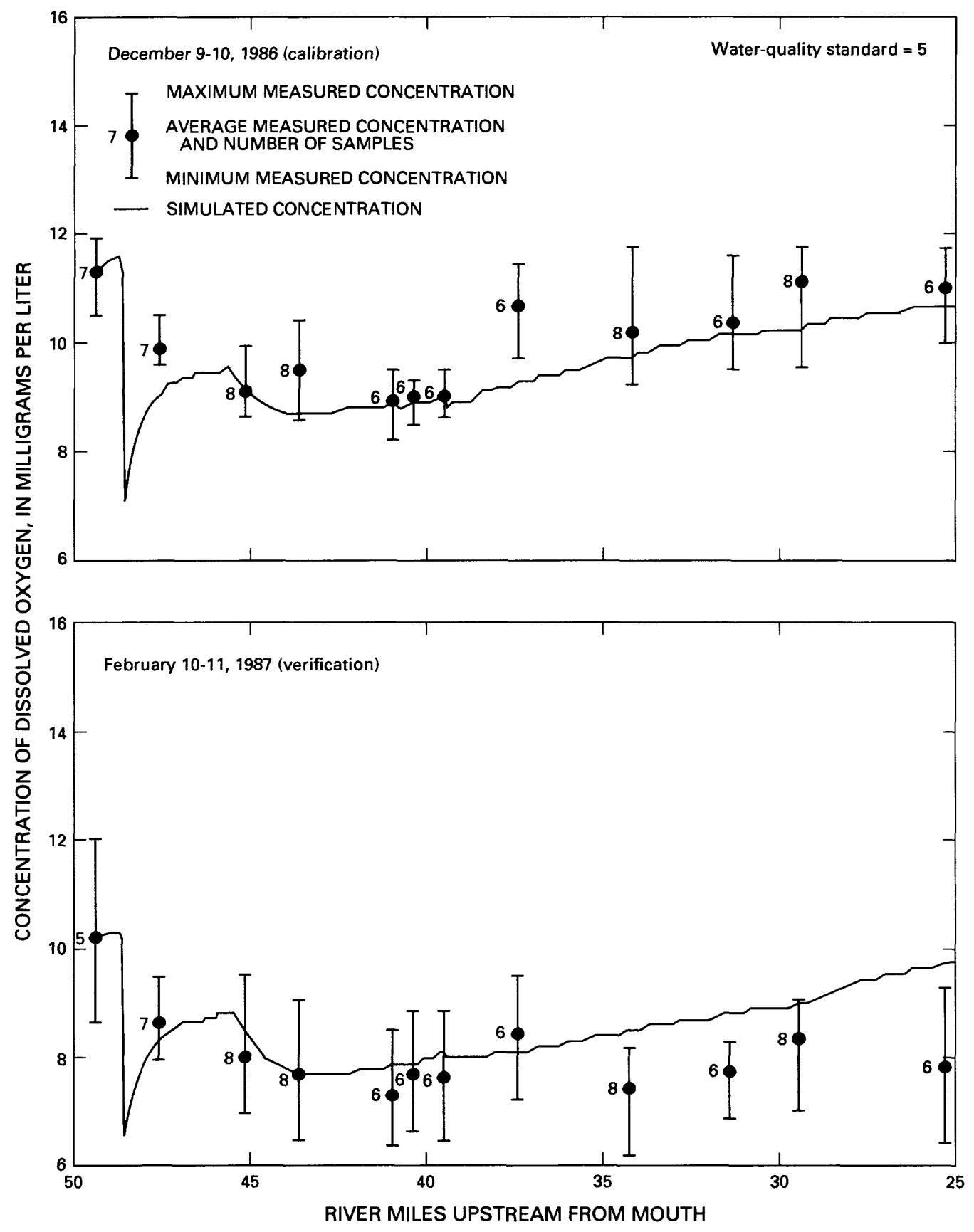

Figure 33.--Simulated and measured concentrations of dissolved oxygen for middle Fountain Creek, December 1986 and February 1987 simulations. 


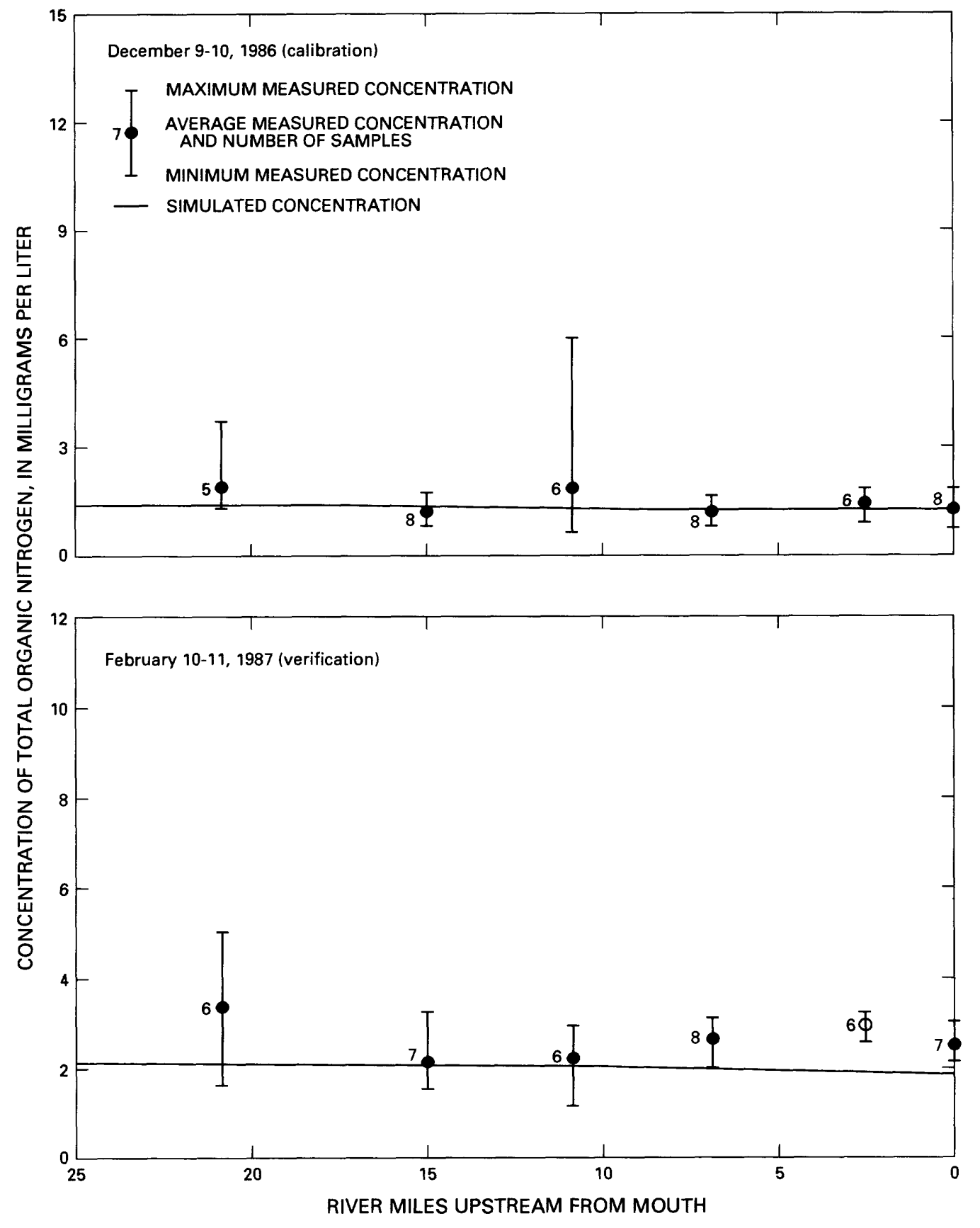

Figure 34.--Simulated and measured concentrations of total organic nitrogen for lower Fountain Creek, December 1986 and February 1987 simulations. 


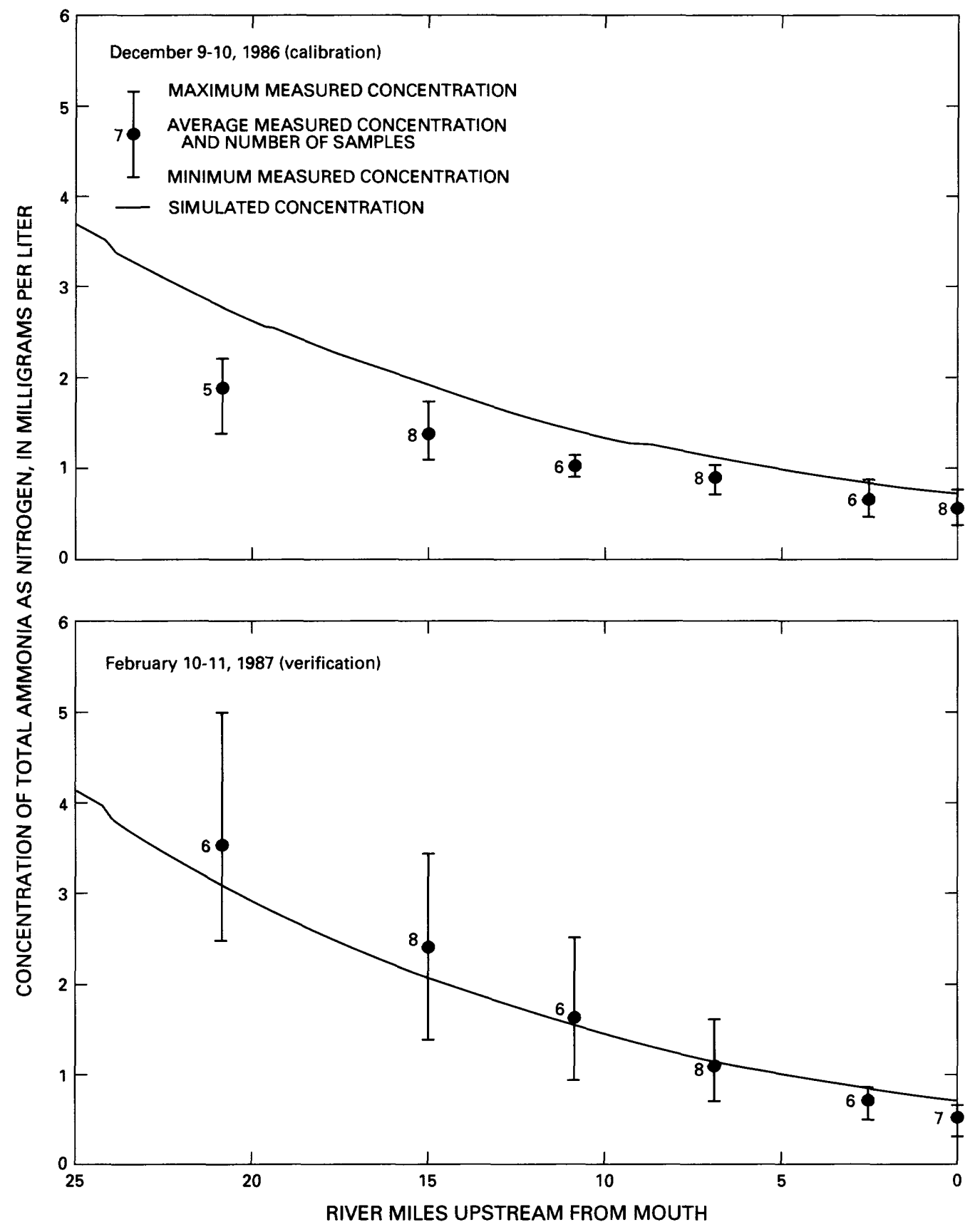

Figure 35.--Simulated and measured concentrations of total ammonia as nitrogen for lower Fountain Creek, December 1986 and February 1987 simulations. 


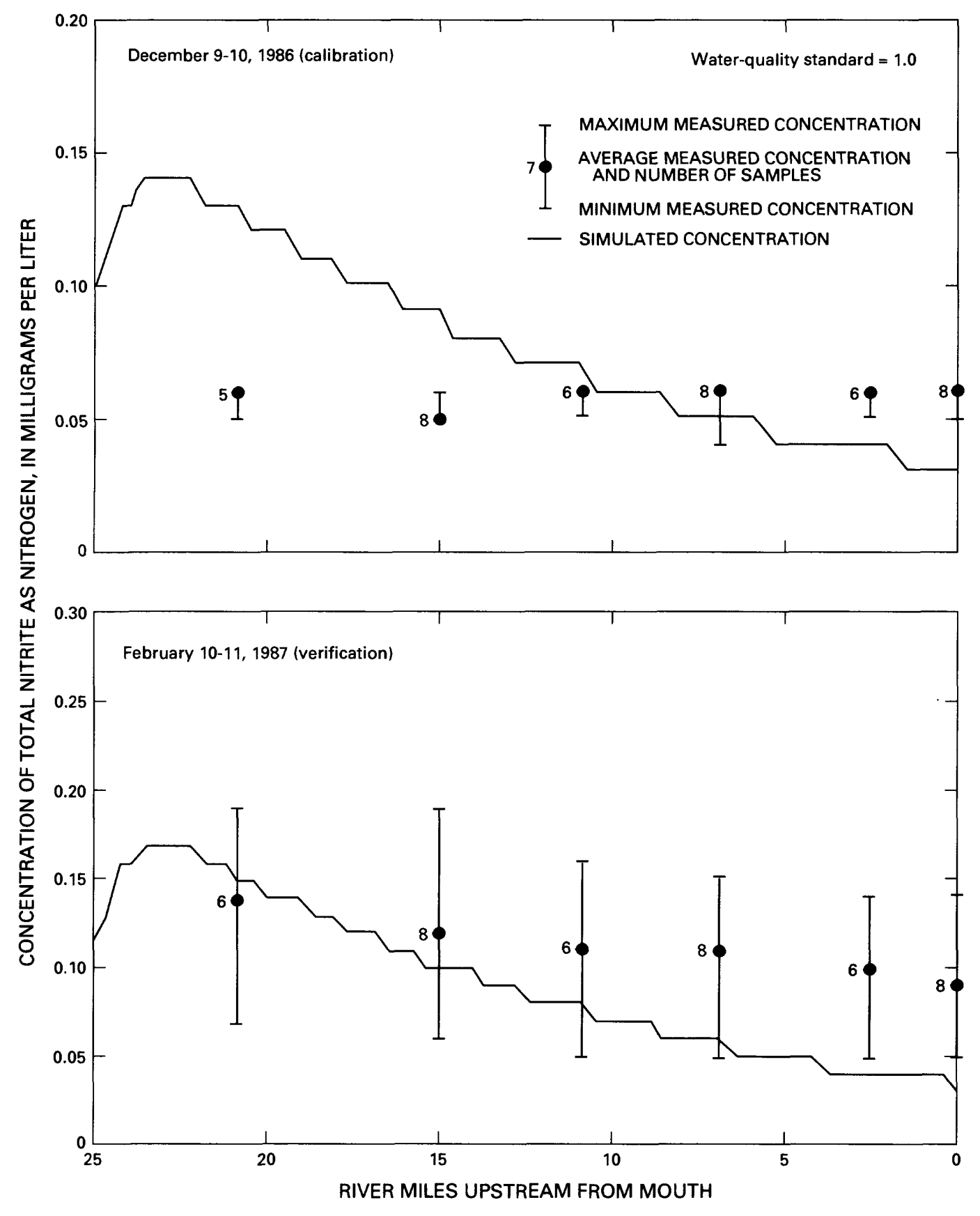

Figure 36.--Simulated and measured concentrations of total nitrite as nitrogen for lower Fountain Creek, December 1986 and February 1987 simulations. 


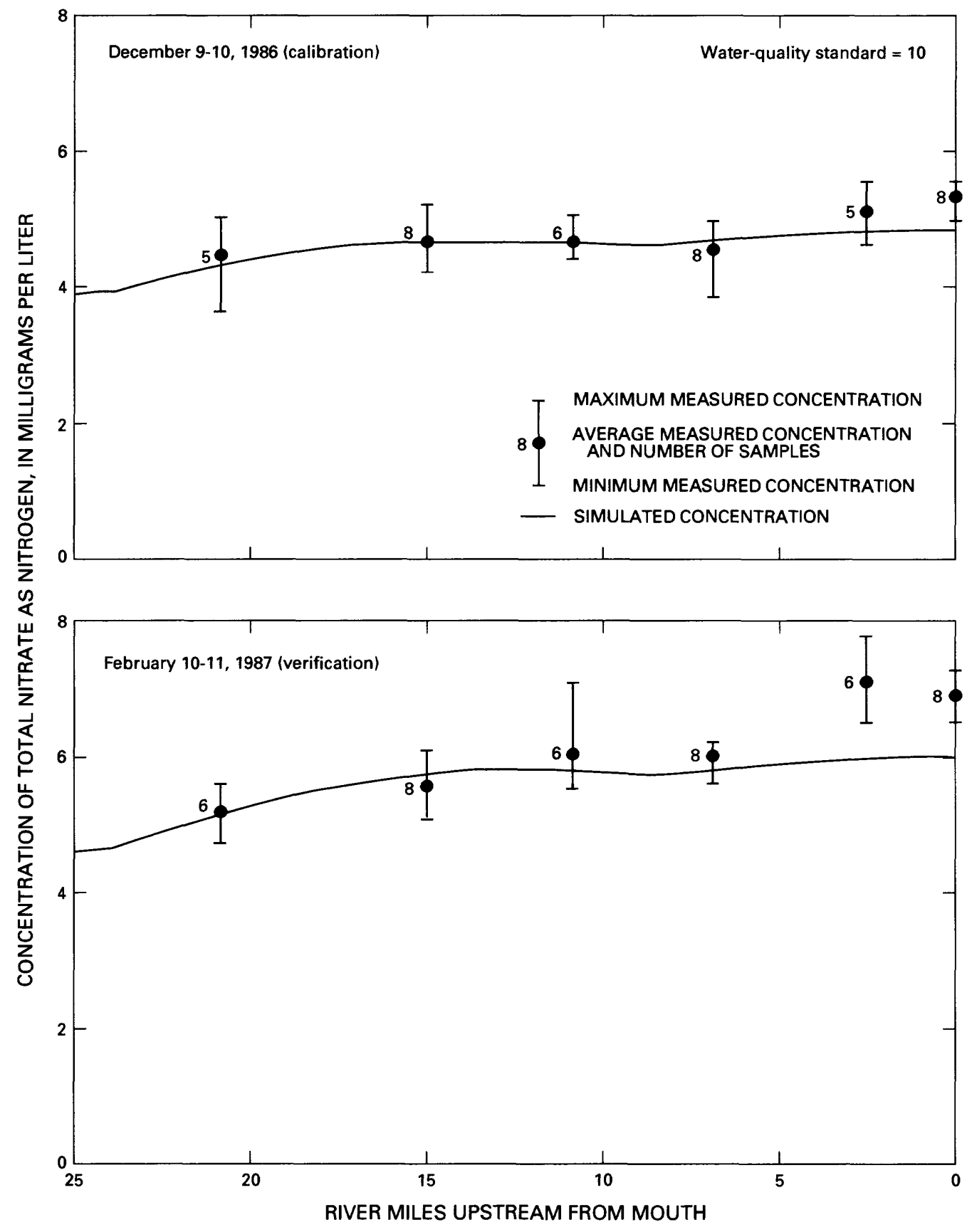

Figure 37.--Simulated and measured concentrations of total nitrate as nitrogen for lower Fountain Creek, December 1986 and February 1987 simulations. 


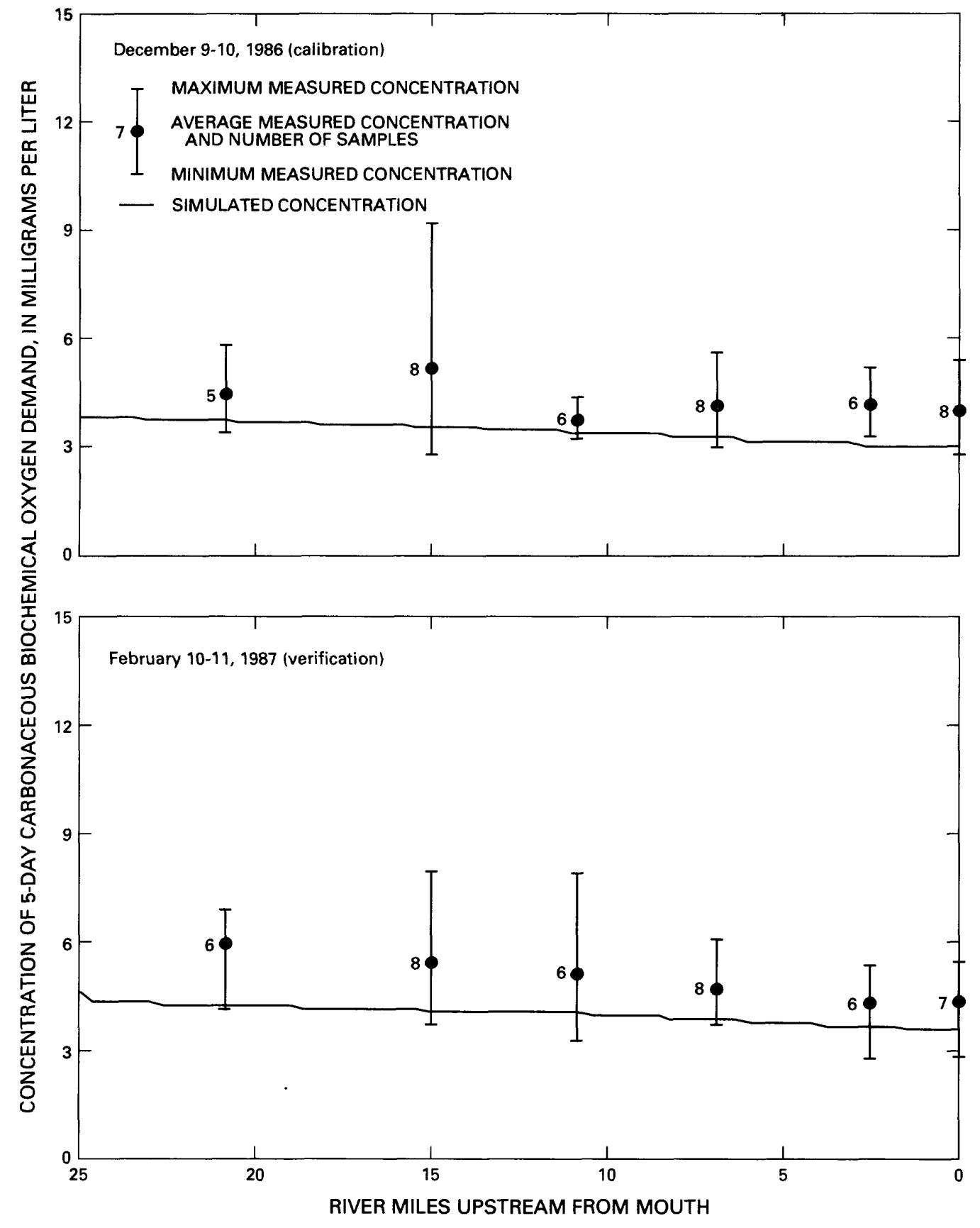

Figure 38.--Simulated and measured concentrations of 5-day carbonaceous biochemical oxygen demand for lower Fountain Creek, December 1986 and February 1987 simulations. 


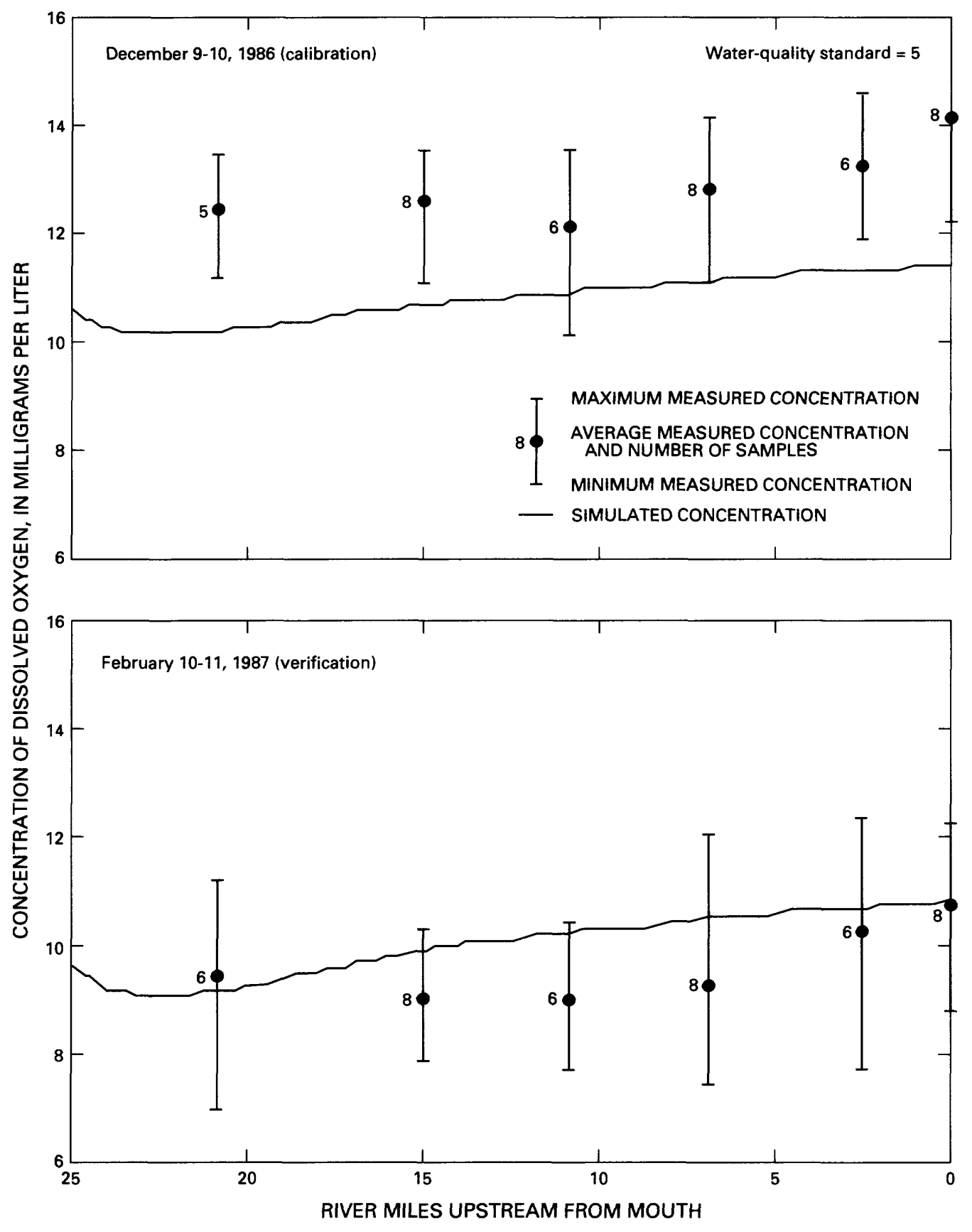

Figure 39.--Simulated and measured concentrations of dissolved oxygen for lower Fountain Creek, December 1986 and February 1987 simulations. 


\section{ESTIMATION OF UN-IONIZED AMMONIA}

In aqueous solutions, ammonia exists in several chemical forms, including ionized ammonia $\left(\mathrm{NH}_{4}{ }^{+}\right)$and un-ionized ammonia $\left(\mathrm{NH}_{3}\right)$. Un-ionized ammonia is of greater concern than ionized ammonia because of its toxicity to fish (European Inland Fisheries Advisory Commission, 1973; Willingham, 1976). This has been recognized in the establishment of water-quality standards. The Colorado Department of Health $(1988 \mathrm{~b})$ has established un-ionized ammonia standards of $0.1 \mathrm{mg} / \mathrm{L}$ for Monument Creek and $0.02 \mathrm{mg} / \mathrm{L}$ for Fountain Creek upstream from the confluence with Monument Creek; no standard (as of 1988) has been established for Fountain Creek downstream from the confluence with Monument Creek (table 1).

Analyses of water samples for concentration of ammonia are made on the basis of total ammonia because the proportions of ionized and un-ionized ammonia depend on $\mathrm{pH}$, temperature, and concentration of dissolved solids. The percentage of un-ionized ammonia increases with increasing $\mathrm{pH}$ and temperature, whereas the percentage decreases with increasing concentration of dissolved solids. An increase in $\mathrm{pH}$ of 0.3 units or an increase in temperature of $9{ }^{\circ} \mathrm{C}$ approximately doubles the percentage of un-ionized ammonia. By contrast, increases in concentration of dissolved solids of $500 \mathrm{mg} / \mathrm{L}$ result in about 3to 5-percent decreases in un-ionized concentration of ammonia, depending on the original concentration of dissolved solids.

\section{Method of Estimation}

The proportion of total ammonia that is in the un-ionized form can be calculated by the equation (Thurston and others, 1974, p. 7):

$$
f=\frac{1}{1+10^{\left(p K_{a}-p H\right)}} \text {, }
$$

where $f=$ decimal fraction of total ammonia as nitrogen that is in the un-ionized form;

$\mathrm{pK}_{\mathrm{a}}=$ dissociation constant for ionized and un-ionized ammonia, temperature dependent; and

$\mathrm{pH}=\mathrm{pH}$, in standard units.

The dissociation constant $\left(\mathrm{pK}_{\mathrm{a}}\right)$, in turn, can be calculated by the equation (Thurston and others, 1974, p. 7):

$$
\mathrm{pK}_{\mathrm{a}}=0.0901821+\left(\frac{2,729.92}{\mathrm{~T}}\right)
$$

where $\mathrm{pK}_{\mathrm{a}}$ = same as defined for equation 12; and

$$
T=\text { temperature, in degrees Celsius }+273.15 \text {. }
$$


The calculation for fraction of un-ionized ammonia (eq. 12) does not consider the effects of concentration of dissolved solids. Measured concentrations of dissolved solids in the downstream reaches of Fountain Creek often are about $2,000 \mathrm{mg} / \mathrm{L}$ (Cain, 1987, p. 89); concentrations this large could have an effect on calculation of un-ionized ammonia. Therefore, $p K_{a}$ values determined by Skarheim (1973, p. 3), which include the effects of concentration of dissolved solids on un-ionized ammonia, were used in the following analysis to solve equation 12 rather than $\mathrm{pK}_{\mathrm{a}}$ values determined by using equation 13 . Equation 12 and the $\mathrm{pK}_{\mathrm{a}}$ values for various temperatures and concentrations of dissolved solids listed by Skarheim (1973, p. 3) were programmed into a new subroutine for the QUAL2E model to calculate an estimated un-ionized ammonia concentration; the method was used for all of the study area. The computer code for the new subroutine is listed in the "Supplemental Information" section of this report.

In addition to equation 12 and the $\mathrm{pK}_{\mathrm{a}}$ values (Skarheim, 1973, p. 3), the method programmed into the model uses the following data: (1) Model-estimated stream temperature, (2) simulated concentrations of total ammonia and dissolved solids, and (3) pH data for each subreach included in the model input. Estimated stream temperature and concentrations of total ammonia previously have been described in this report.

Dissolved solids were modeled as a conservative constituent but were not included in any calibration or verification analysis. Dissolved-solids data were not available for the calibration and verification data sets; however, specific-conductance data were available (Kubn and Ortiz, 1989). Concentrations of dissolved solids were estimated for the water-quality data sets by using the relations between specific conductance and concentration of dissolved solids presented in Cain (1987, p. 37).

Concentrations of dissolved solids in ground-water discharge also were estimated. First, a relation between specific conductance and concentration of dissolved solids was derived for ground water in the alluvial aquifer along Fountain Creek downstream from Colorado Springs. The relation was derived by using linear least-squares regression of specific conductance and dissolvedsolids data for selected alluvial wells along Fountain Creek (Cain and Edelmann, 1986, table 6; D.T. Chafin, U.S. Geological Survey, written commun., 1988). The relation derived has a coefficient of determination of 0.99 , has a standard error of estimate of $54 \mathrm{mg} / \mathrm{L}$, and is based on 80 data pairs. Second, specific conductance of ground-water discharge for subreaches on Fountain Creek downstream from Colorado Springs was estimated from the graphical relation between river mile and specific conductance of ground water presented in Cain and Edelmann (1986, fig. 8). Third, concentrations of dissolved solids in ground-water discharge were estimated by using the regression equation previously derived.

Concentrations of dissolved solids in ground-water discharge estimated by the method ranged from about $470 \mathrm{mg} / \mathrm{L}$ for subreaches near Colorado Springs to about $1,450 \mathrm{mg} / \mathrm{L}$ for subreaches near the mouth of Fountain Creek. Concentration of dissolved solids of $300 \mathrm{mg} / \mathrm{L}$ was assumed for ground-water discharge for all subreaches upstream from the confluence of Monument and Fountain Creeks. 
Measurements of $\mathrm{pH}$ made at the time of sampling for the two calibration and two verification data sets (Kuhn and Ortiz, 1989) were used to estimate the subreach values for $\mathrm{pH}$ to be used in solution of equation 12 . First, the median $\mathrm{pH}$ values at each sampling site on Monument and Fountain Creeks (table 2) were plotted by river mile for each of the four water-quality data sets. Then, $\mathrm{pH}$ values for the model subreaches were estimated from these graphs; the estimated subreach value for each calibration and verification data set is included in the model input. The maximum, median, and minimum measured $\mathrm{pH}$ values at each site for the four diel-sampling periods and the estimated $\mathrm{pH}$ values for each model subreach are shown in figures 40-42. In addition, for the example simulations (see "Model Simulations" section of this report) the median $\mathrm{pH}$ values of both data sets for each stream reach were used to estimate the $\mathrm{pH}$ values used for model input.

Because of the use of the methods just described, the resultant simulated concentrations of un-ionized ammonia are considered to be estimated concentrations. The greatest uncertainty in estimated concentration of un-ionized ammonia is attributed to the simulated concentration of total ammonia and the values input for $\mathrm{pH}$. Uncertainty in estimated concentration of un-ionized ammonia attributable to simulated concentration of total ammonia will be proportional to the exror in simulated total ammonia; the uncertainty will be least where calibration and verification of ammonia were best. Because the $\mathrm{pH}$ values are specified in the input data, the effects of different pH values on un-ionized ammonia can be evaluated easily by changing the pH input data for one or more subreaches.

\section{$\underline{\text { Results }}$}

Use of the method just described to estimate un-ionized ammonia was evaluated by using the water-quality data sets. Concentration of un-ionized ammonia was calculated for each water-quality sample obtained for sampling sites on Monument and Fountain Creeks on the basis of the: (1) Stream temperature and $\mathrm{pH}$ measured at the time of sample collection; (2) laboratory analysis of concentration of total ammonia; and (3) concentration of dissolved solids, estimated by use of the relations between specific conductance and concentration of dissolved solids presented in Cain (1987, p. 37). These calculations for concentration of un-ionized ammonia can be considered to be the best possible because only concentration of dissolved solids was estimated, and the effect of any error would be small.

The simulated and calculated concentrations of un-ionized ammonia are shown in figures 43-45. The simulated concentrations reasonably agree with the calculated concentrations. A notable exception is the July 1987 simulation for Monument Creek (fig. 43) because of the inaccurate simulation of total ammonia (fig. 11). On the basis of the results shown in figures 43-45, the method to estimate concentration of un-ionized ammonia was considered acceptable. 

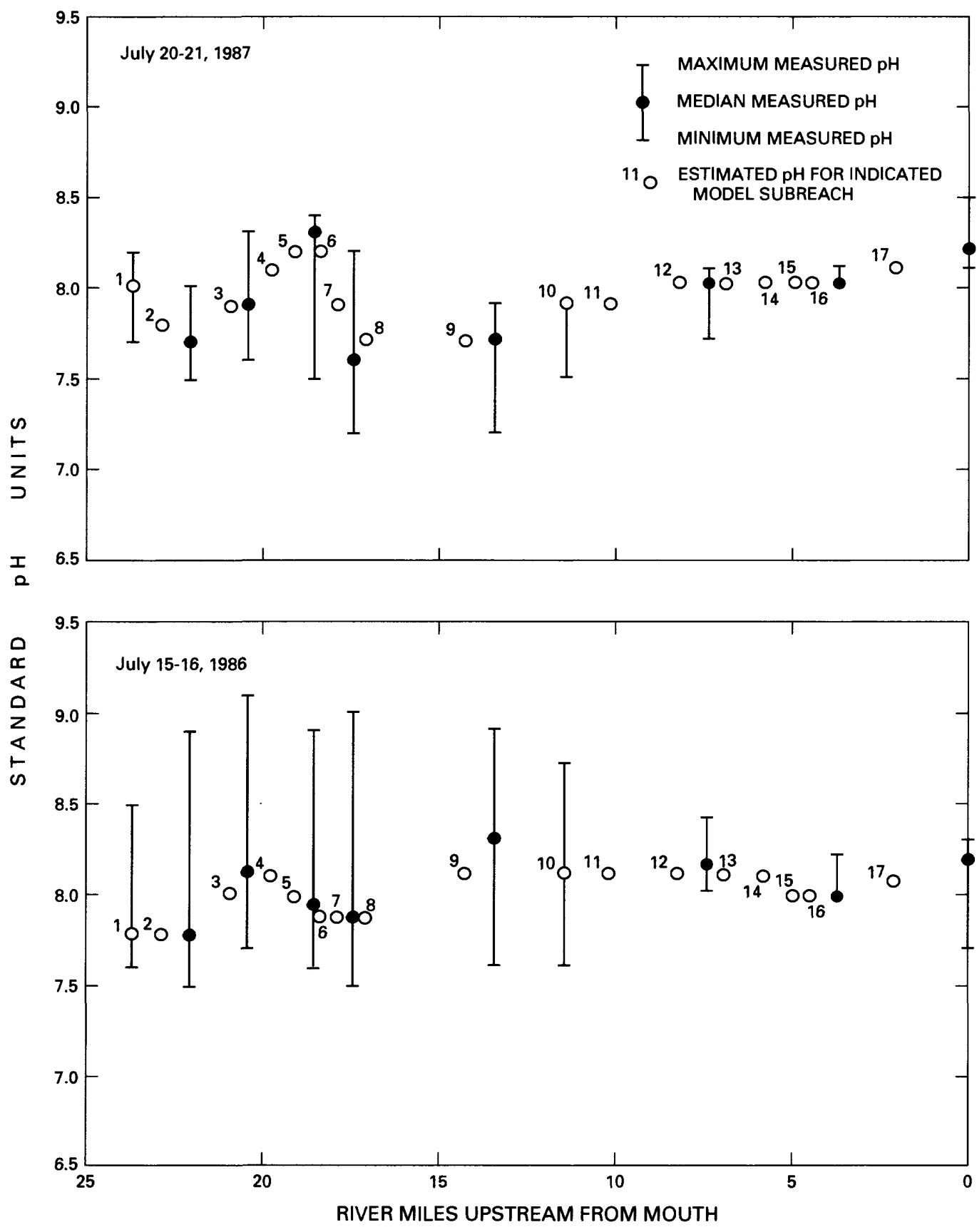

Figure 40.--Estimated and measured pH values for Monument Creek, July 1987 and July 1986 simulations. 

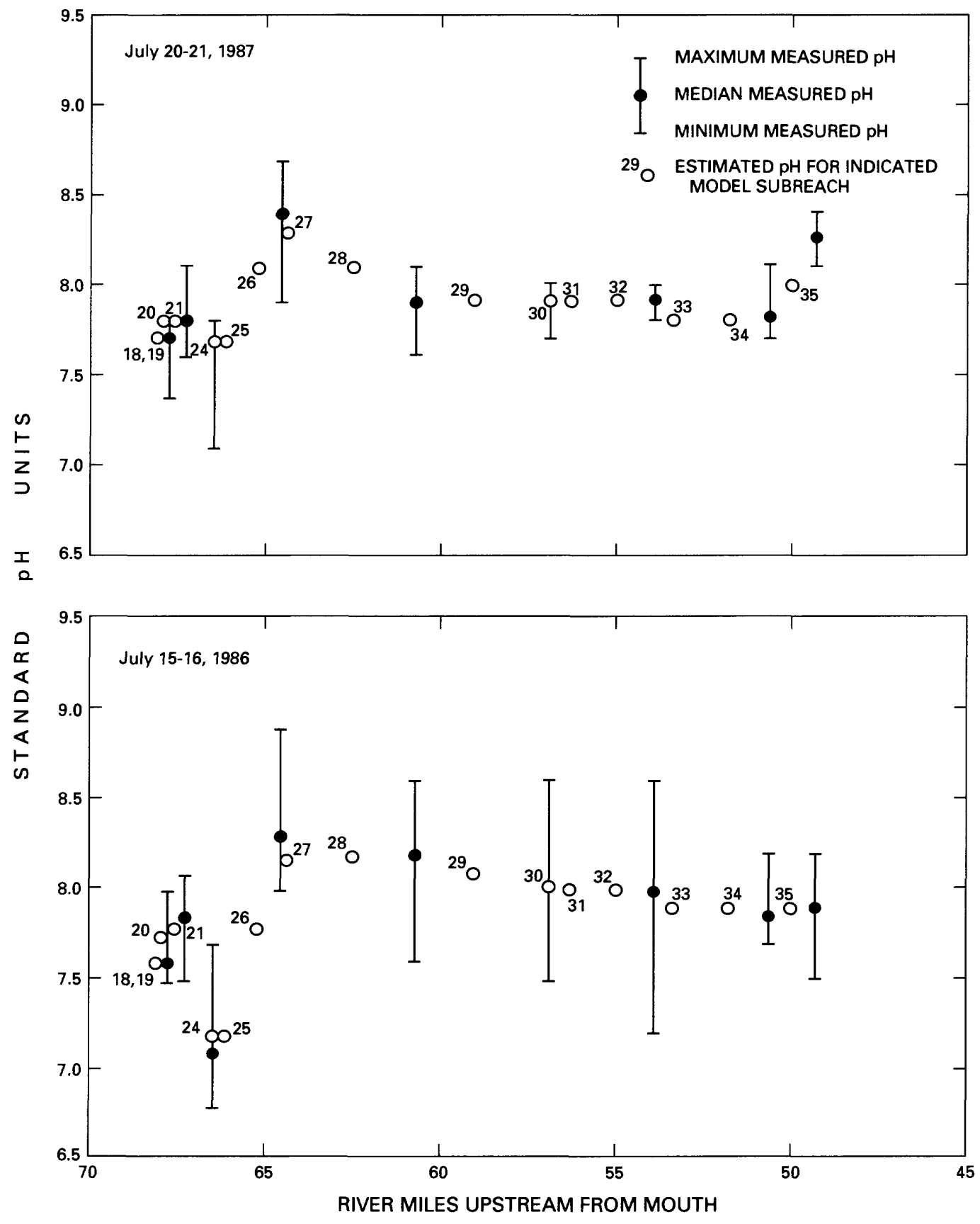

Figure 41.--Estimated and measured $\mathrm{pH}$ values for Fountain Creek, July 1987 and July 1986 simulations. 

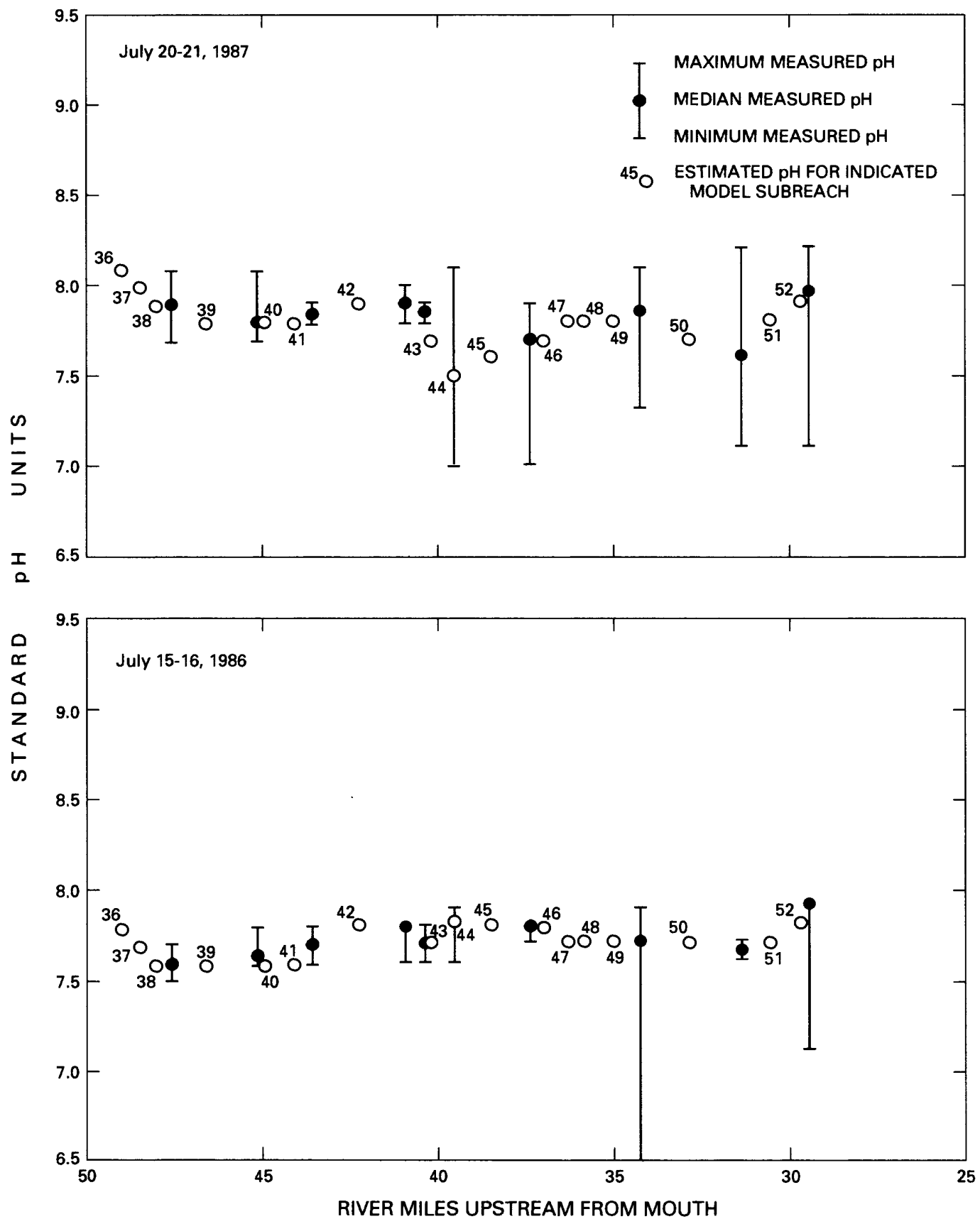

Figure 41.--Estimated and measured $\mathrm{pH}$ values for Fountain Creek, July 1987 and July 1986 simulations--Continued. 

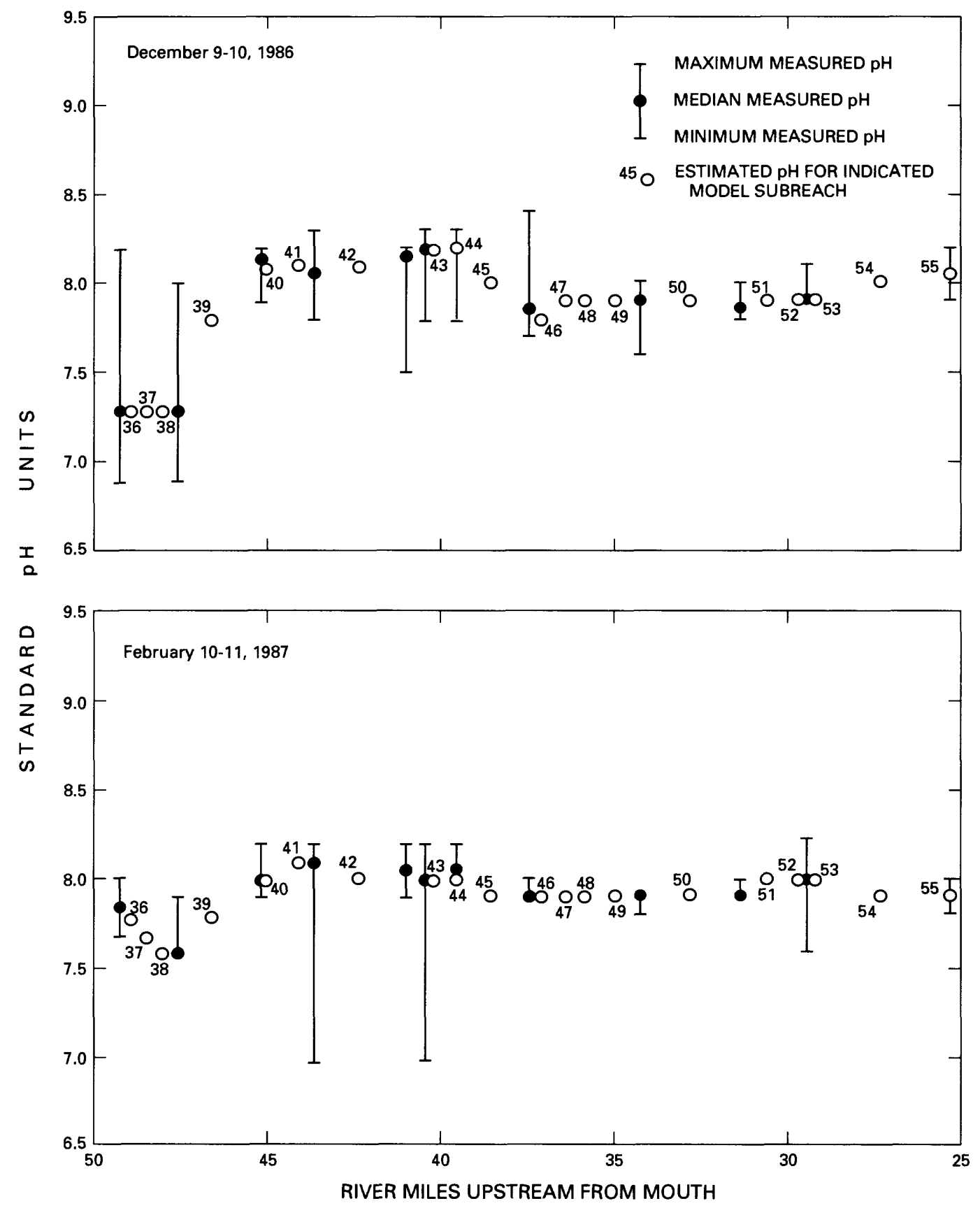

Figure 42.--Estimated and measured $\mathrm{pH}$ values for Fountain Creek, December 1986 and February 1987 simulations. 


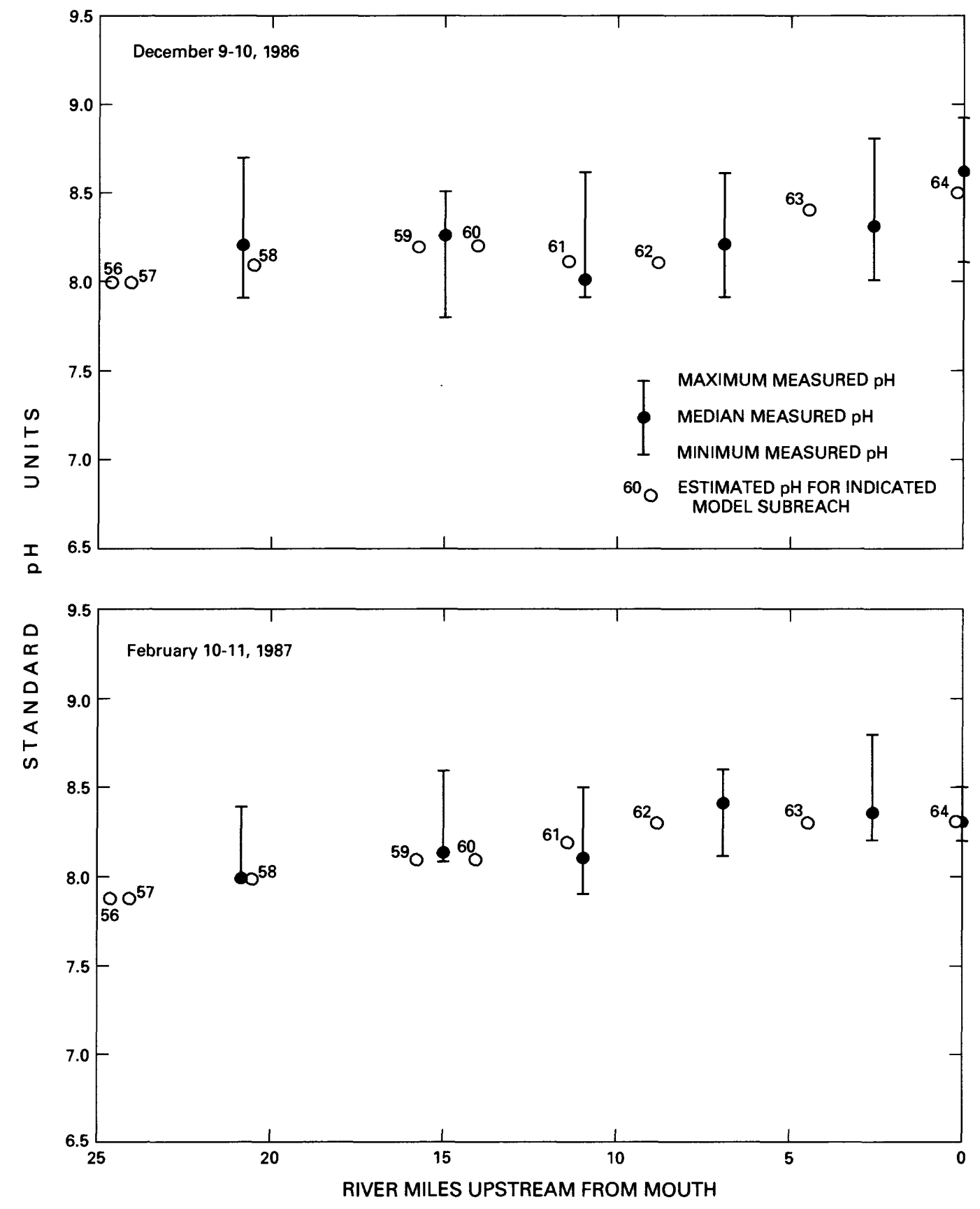

Figure 42.--Estimated and measured $\mathrm{pH}$ values for Fountain Creek, December 1986 and February 1987 simulations--Continued. 


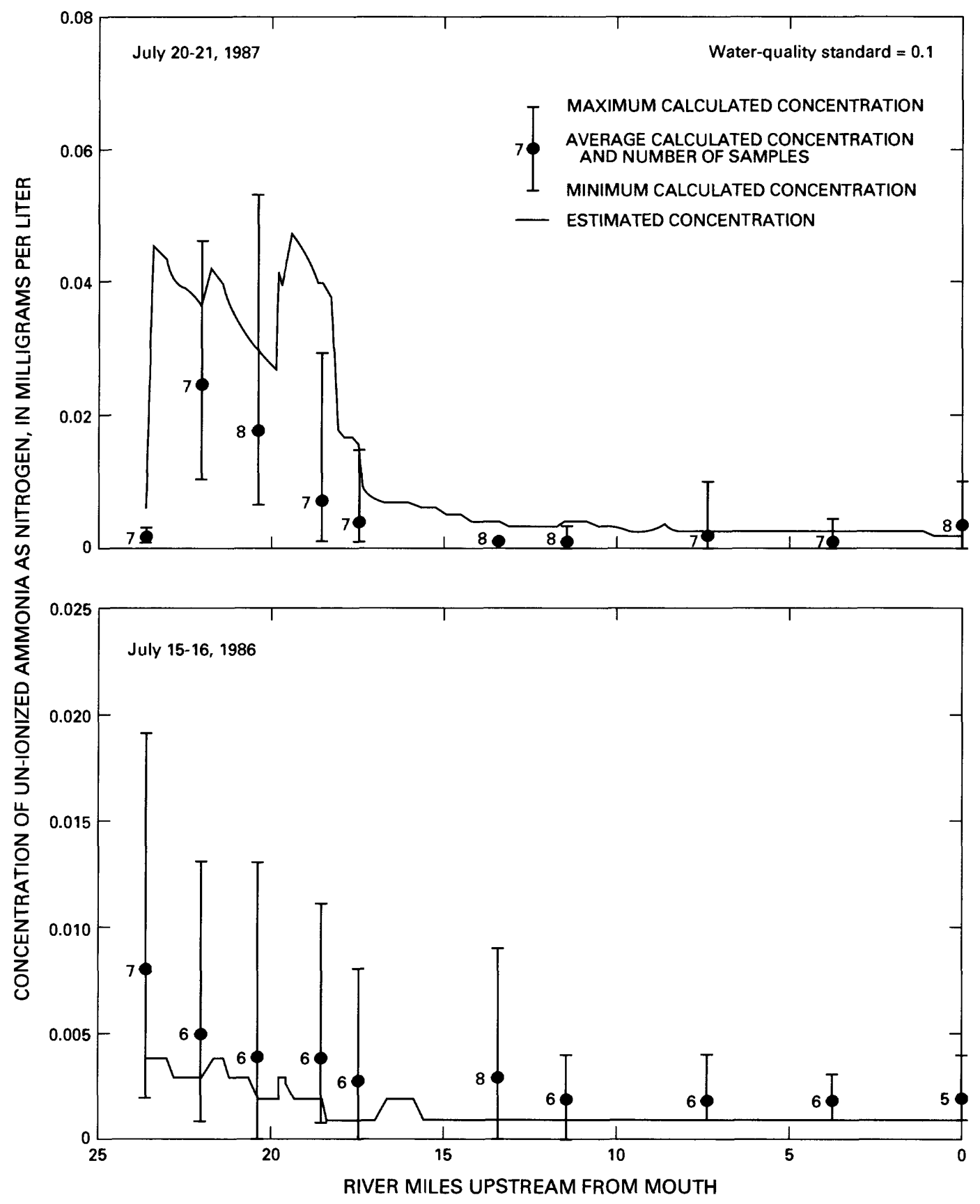

Figure 43.--Estimated and calculated concentrations of un-ionized ammonia as nitrogen for Monument Creek, July 1987 and July 1986 simulations. 


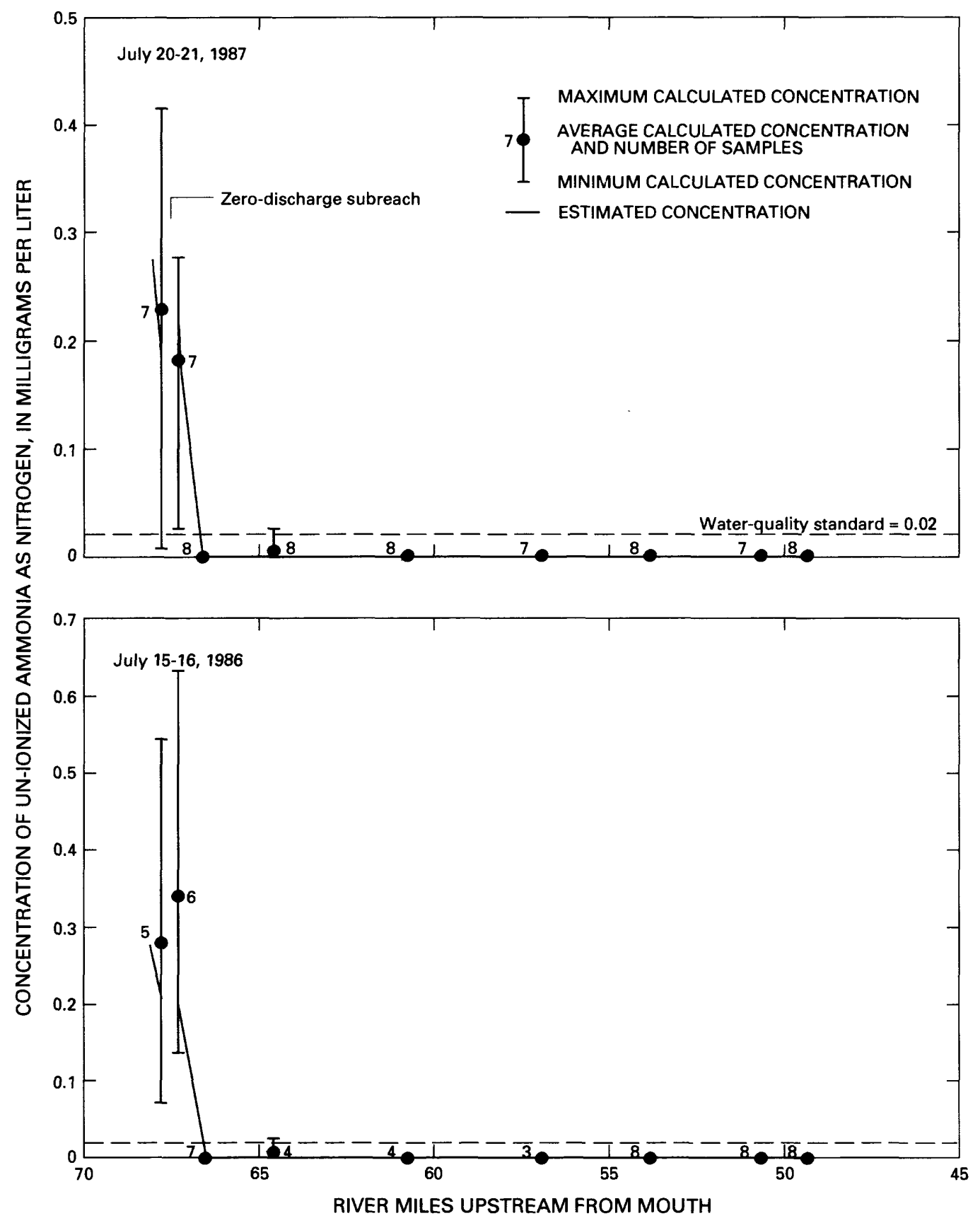

Figure 44.--Estimated and calculated concentrations of un-ionized ammonia as nitrogen for Fountain Creek, July 1987 and July 1986 simulations. 


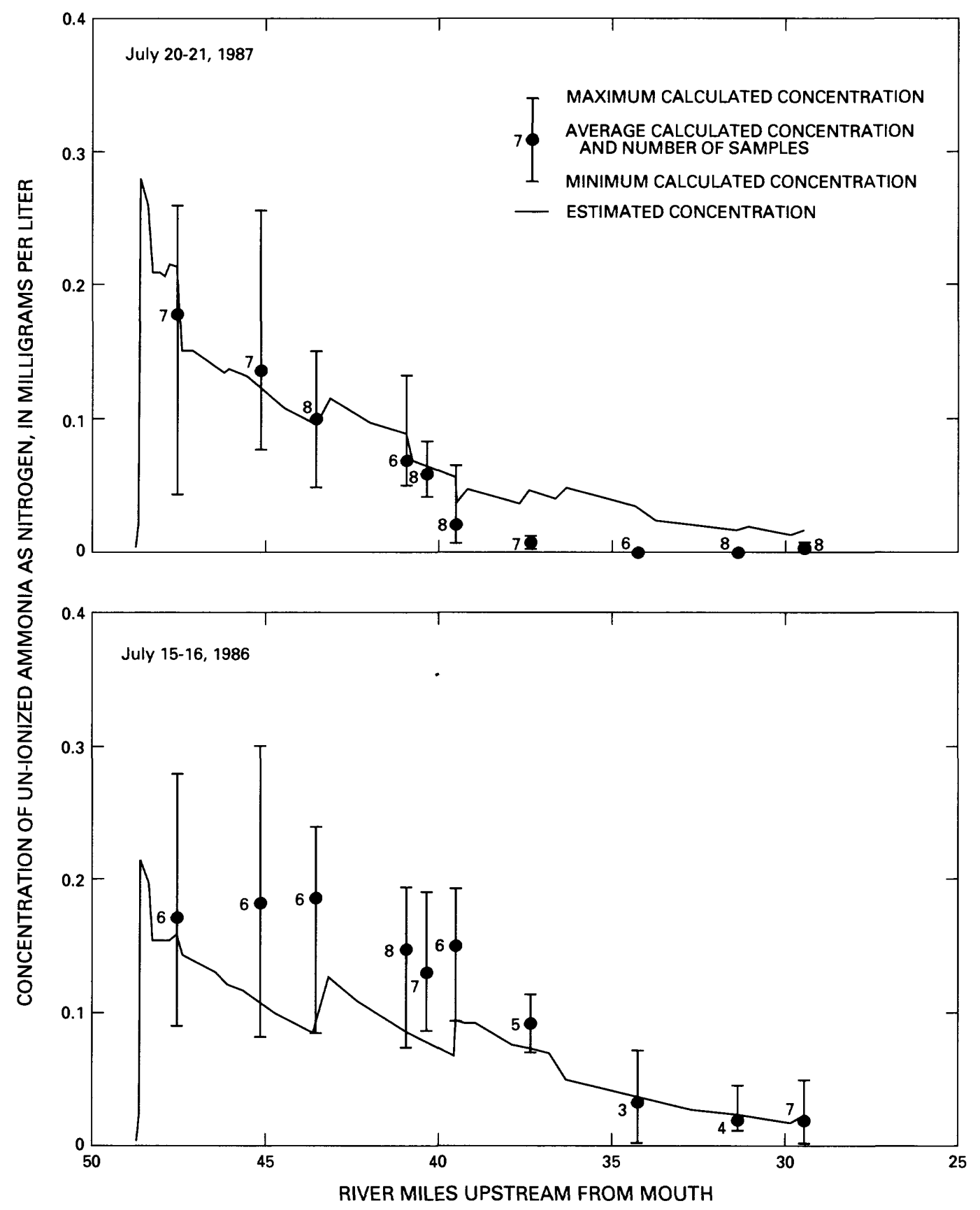

Figure 44.--Estimated and calculated concentrations of un-ionized ammonia as nitrogen for Fountain Creek, July 1987 and July 1986 simulations--Continued. 


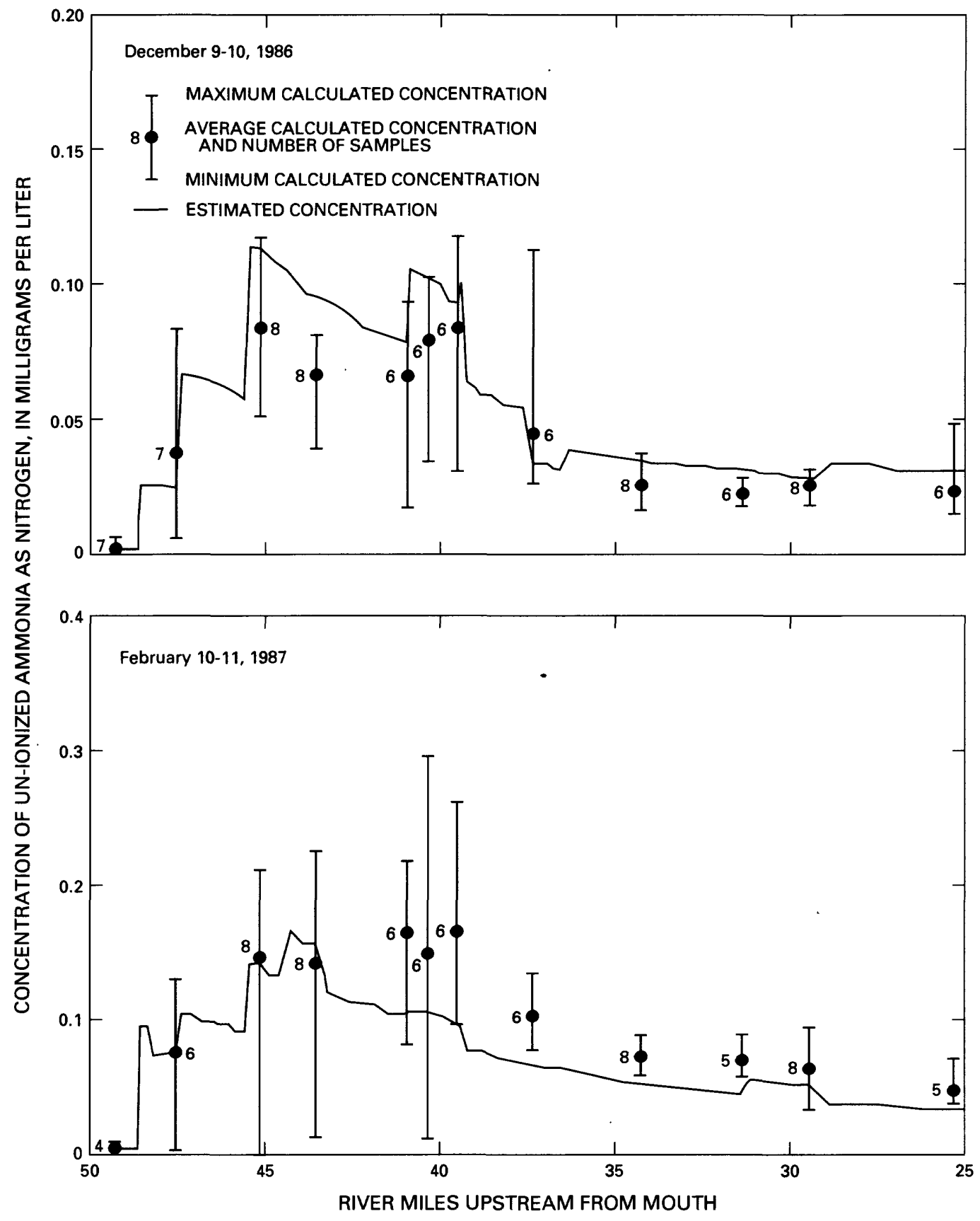

Figure 45.--Estimated and calculated concentrations of un-ionized ammonia as nitrogen for Fountain Creek, December 1986 and February 1987 simulations. 


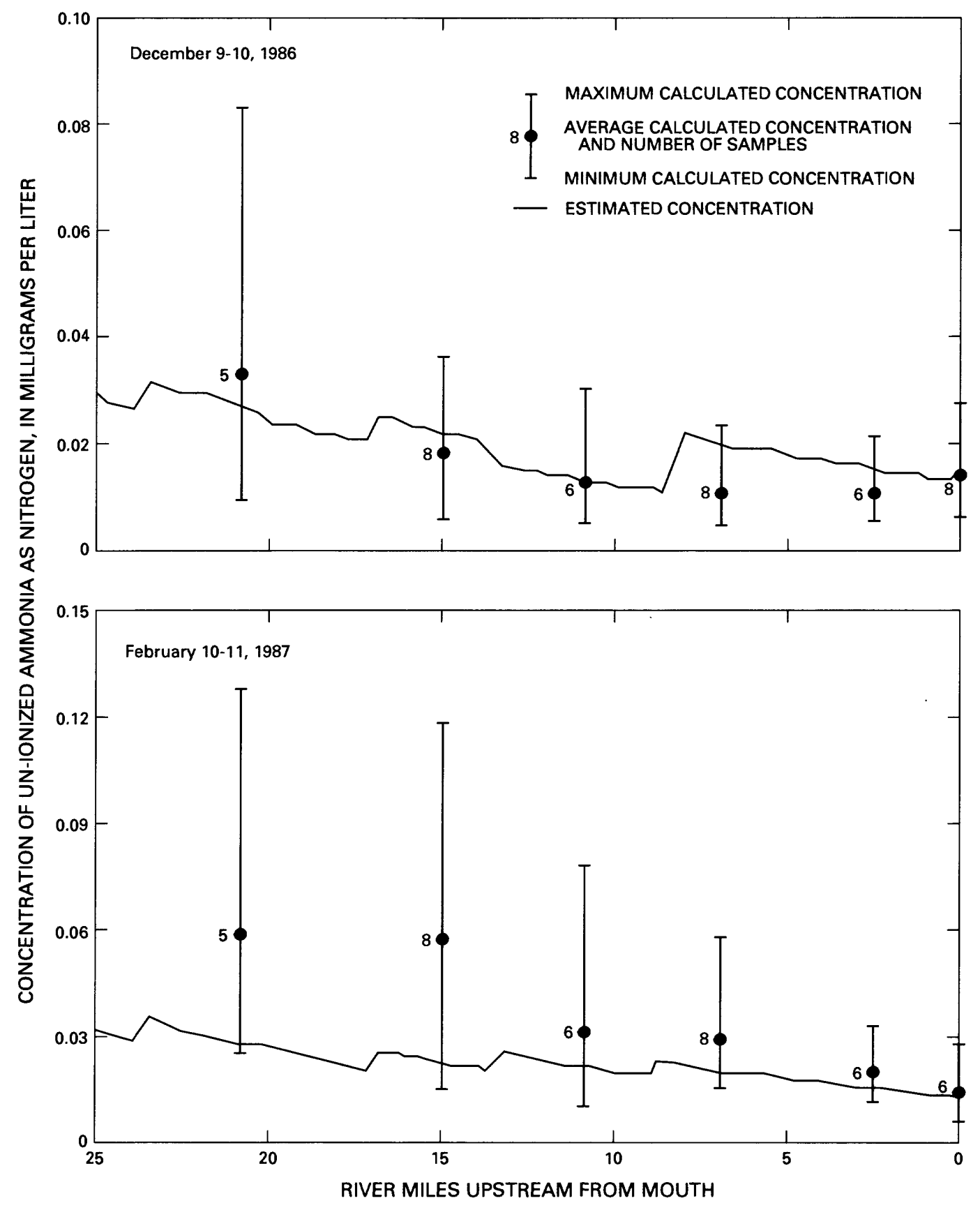

Figure 45.--Estimated and calculated concentrations of un-ionized ammonia as nitrogen for Fountain Creek, December 1986 and February 1987 simulations--Continued. 


\section{ESTIMATION OF MINIMUM DISCHARGES}

Evaluation of the effects of wastewater on a stream usually is made in reference to some specific minimum discharge in the stream. Prior to October 1988, the 7-day, 10-year minimum discharge (hereinafter referred to as Q7,10) generally was used in application of stream water-quality standards in Colorado (Colorado Department of Health, 1979, p. 13, 29-30), as well as in other states. The $Q 7,10$, as well as other minimum discharges, has a statistical basis and is computed by frequency analysis of daily discharge data available for streamflow-gaging stations; Riggs (1968) describes the methods.

The selection of $Q 7,10$ in application of stream water-quality standards apparently was somewhat arbitrary and was not based on stream biology or other water-quality considerations (Paulson, 1989, p. 94). Consequently, a method was developed to compute minimum discharges that had a biological basis (U.S. Environmental Protection Agency, 1986); description of the method is beyond the scope of this report. This method of minimum-discharge computation was adopted in new water-quality regulations that became effective in October 1988 (Colorado Department of Health, 1988a).

The regulations that became effective in October 1988 specified two different water-quality standards for Colorado streams, a chronic standard and an acute standard (Colorado Department of Health, 1988a, p. 2-3). A different minimum discharge was to apply to each standard (Colorado Department of Health, 1988a, p. 24):
"Water quality standards shall apply at all times except where surface waters are below the empirically [biologically] based average 30-day low flow [minimum discharge] with an average 1-in-3-year recurrence interval for chronic (30-day) standards or the empirically [biologically] based 1-day low flow [minimum discharge] with an average 1-in-3-year recurrence interval for acute (1-day) standards, or the equivalent statistically based flow [discharge]."

Hereinafter, the 1-day, 3-year minimum discharge will be referred to as $B Q 1,3$ and the 30-day, 3-year minimum discharge will be referred to as $B Q 30,3$. Application of the calibrated and verified model to evaluate the effects of present and projected wastewater discharges to Monument and Fountain Creeks probably will be made on the basis of these two minimum discharges. The following paragraphs present a description of the methods used to estimate these minimum discharges for Monument and Fountain Creeks and the results of the estimates.

\section{Methods of Estimation and Results}

The biologically based method for computation of minimum discharge (U.S. Environmental Protection Agency, 1986) uses daily discharge data from gaging stations. However, for application of the QUAL2E model, it is necessary to know the minimum discharge at many locations along Monument and Fountain Creeks, not just at the gaging stations. Although the Environmental 
Protection Agency (1986) does not describe a method to estimate biologically based minimum discharges for nongaged sites, methods to estimate statistically based minimum discharges for nongaged sites have been described (Riggs, 1972). These methods were assumed to be applicable to estimating biologically based minimum discharges for nongaged sites.

A minimum discharge can be estimated for a nongaged site by graphical correlation of discharge measurements made at the site during periods of small discharge with daily discharge data from a nearby gaging station (Riggs, 1972, p. 8-13). The measured discharges at the nongaged site are plotted against the average daily discharges at the nearby gaged site for the days on which the measurements were made. The discharge at the nongaged site for a specified duration and recurrence interval then can be estimated from the graph by using the computed biologically or statistically based discharge with the same duration and recurrence interval for the gaged site. An example of the graphical correlation for a site on Monument Creek is shown in figure 46.

Several sets of minimum-discharge measurements for Monument and Fountain Creeks (U.S. Geological Survey, 1979, p. 378-82; U.S. Geological Survey, 1986, p. 328-30; R.D. Steger, U.S. Geological Survey, written commun., 1988) were used in the graphical correlation analysis. Some of the discharge measurements (Kuhn and Ortiz, 1989) made for the study described in this report also were used in the analysis. Eleven years of record, the 1977 through 1987 climate years (April 1 to March 31), were used to compute the minimum discharges. The biologically based minimum discharges for gaging stations on Monument and Fountain Creeks (table 17) were computed by using a computer program available from the U.S. Environmental Protection Agency (1986).

In future applications of the model, the discharge from the various WWTF's would be in addition to the estimated minimum discharges for Monument and Fountain Creeks. Therefore, discharge data used for the graphical correlation analysis were adjusted for the effects of diversion and wastewater discharge. The adjustment in discharge at a site was made on the basis of the distance that the site was from an upstream diversion or WWTF inflow and the quantity of the diversion or inflow. The need for the adjustment was small for Monument Creek because the effects of diversion and wastewater discharge were not large. However, the effects of diversion and wastewater discharge on Fountain Creek downstream from the Colorado Springs WWTF can be large. In addition, the rate of discharge by the Colorado Springs WWTF varies during a 24-hour period. This results in daily variation in discharge in Fountain Creek; the variation generally decreases as the distance downstream from the WWTF increases. Therefore, average daily discharge data, which also were adjusted for the effects of diversion and wastewater discharge, were used in the correlation analysis for Fountain Creek downstream from the Colorado Springs WWTF; an example is shown in figure 47. Correlation graphs, in addition to those shown in figures 46 and 47 , were prepared for other sites on Monument and Fountain Creeks; presentation of each of these is beyond the scope of this report. 


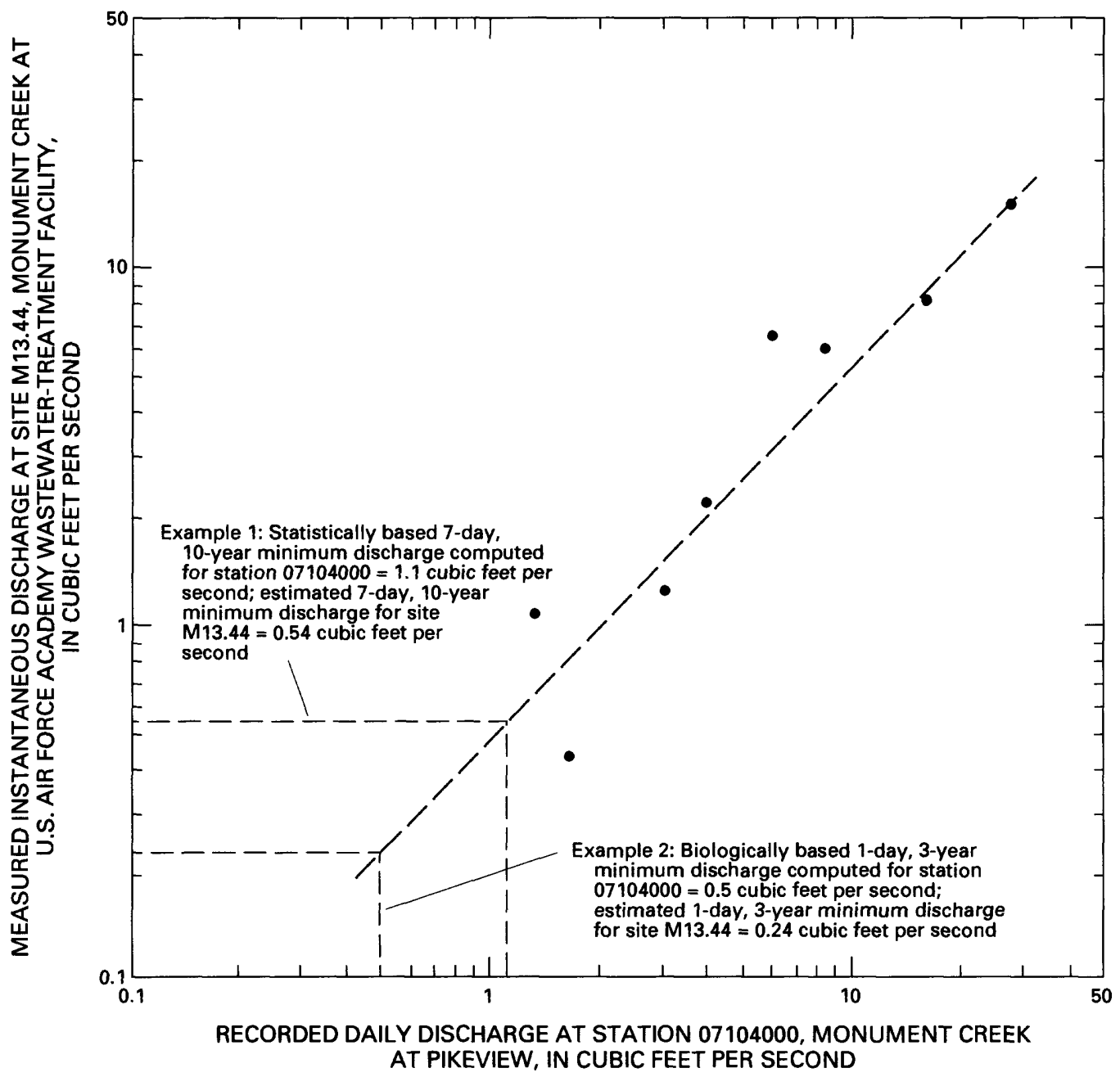

Figure 46.--Relation between measured instantaneous discharge at site M13.44 Monument Creek at U.S. Air Force Academy Wastewater-Treatment Facility and recorded daily discharge at station 07104000 Monument Creek at Pikeview. 


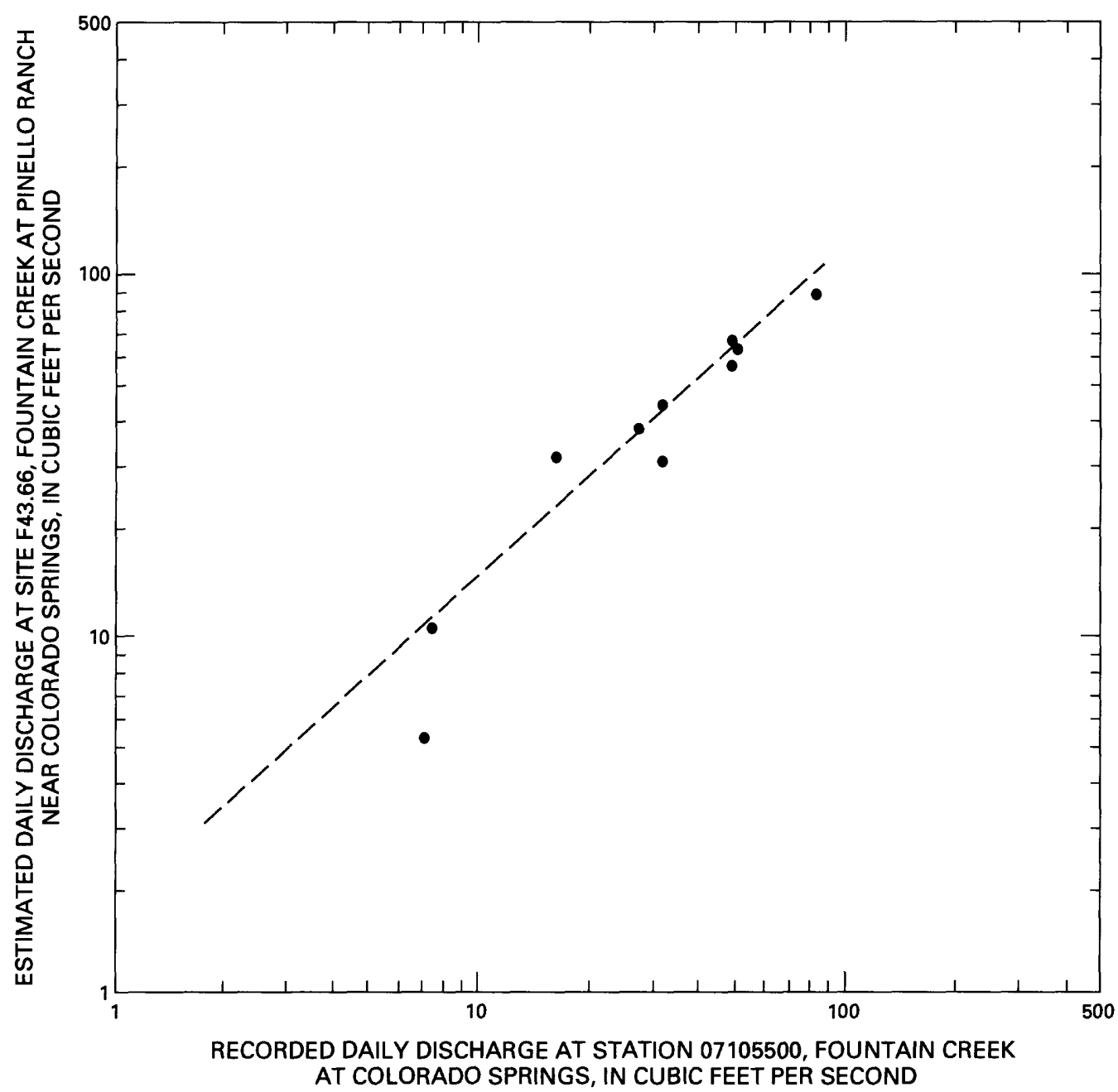

Figure 47.--Relation between estimated daily discharge at site F43.66 Fountain Creek at Pinello Ranch near Colorado Springs and recorded daily discharge at station 07105500 Fountain Creek at Colorado Springs. 
Table 17.--Computed annual minimum discharges for selected streamflow-gaging stations on Monument Creek and Fountain Creek

[Period of record used for analysis is 1977-87 climate years. Discharges in cubic feet per second]

\begin{tabular}{|c|c|c|c|c|}
\hline \multirow{2}{*}{$\begin{array}{l}\text { Streamflow- } \\
\text { gaging } \\
\text { station } \\
\text { number } \\
\text { (figure 1) }\end{array}$} & \multicolumn{2}{|c|}{$\begin{array}{l}\text { Biologically based minimum } \\
\text { discharge for the indicated } \\
\text { duration and a } 3 \text {-year } \\
\text { recurrence interval }\end{array}$} & \multicolumn{2}{|c|}{$\begin{array}{l}\text { Statistically based minimum } \\
\text { discharge for the indicated } \\
\text { duration and a } 10 \text {-year } \\
\text { recurrence interval }\end{array}$} \\
\hline & $\begin{array}{l}1 \text { day } \\
(\mathrm{BQ} 1,3)^{1}\end{array}$ & $\begin{array}{c}30 \text { days } \\
(\mathrm{BQ} 30,3)^{2}\end{array}$ & $\begin{array}{c}1 \text { day } \\
(Q 1,10)^{3}\end{array}$ & $\begin{array}{c}7 \text { days } \\
(Q 7,10)^{4}\end{array}$ \\
\hline $\begin{array}{l}07104000 \\
07103700 \\
07105500 \\
07105800\end{array}$ & $\begin{array}{l}0.5 \\
3.2 \\
2.3 \\
10\end{array}$ & $\begin{array}{r}1.6 \\
4.8 \\
5.0 \\
16\end{array}$ & $\begin{array}{l}0.8 \\
3.0 \\
3.5 \\
9.6\end{array}$ & $\begin{array}{l}1.1 \\
4.1 \\
4.7 \\
11\end{array}$ \\
\hline
\end{tabular}

${ }^{1} \mathrm{BQ1}, 3$ is an biologically based minimum discharge having a duration of 1 day and a recurrence interval of 3 years.

${ }^{2} \mathrm{BQ} 30,3$ is an biologically based minimum discharge having a duration of 30 days and a recurrence interval of 3 years.

${ }^{3} \mathrm{Q} 1,10$ is a statistically based minimum discharge having a duration of 1 day and a recurrence interval of 10 years.

${ }^{4} Q 7,10$ is a statistically based minimum discharge having a duration of 7 days and a recurrence interval of 10 years.

The computed minimum discharges for gaged sites (table 17) and the estimated minimum discharges from the graphical correlation analysis were used to estimate $\mathrm{BQ1}, 3$ and $\mathrm{BQ} 30,3$ minimum-discharge relations for the summer stream reach; the results are shown in figures 48-50. No graphical correlation analysis was made for upper Fountain Creek because data were insufficient. Generally, only about ten or fewer data points were available for each correlation graph, and the graphs usually needed to be extended beyond the data points (figs. 46-47). Therefore, the estimated minimum discharge at a nongaged site could vary depending on interpretation of the data points and fit of the correlation line. Some of this possible variation in the estimated minimum discharge for nongaged sites is shown in figure 48 . The estimated minimum-discharge relations were assumed to be linear, and the computed minimum discharges for the gaged sites were given full weight (figs. 48-50).

Because no estimates of minimum discharge were available for Fountain Creek upstream from station 07103700 , the relations shown in figure 49 are subject to more uncertainty then those shown in figures 48 and 50 . However, the effects of current wastewater discharges on upper Fountain Creek are small (see "Results for Summer Stream Reach" section of this report), and the primary source of wastewater discharge, the Woodland Park WWTF, will cease to discharge into Fountain Creek in the near future (Pikes Peak Area Council of Governments, written commun., 1988). Therefore, the effect of the uncertainty in the minimum-discharge relations for upper Fountain Creek will not be large in future applications of the model. 


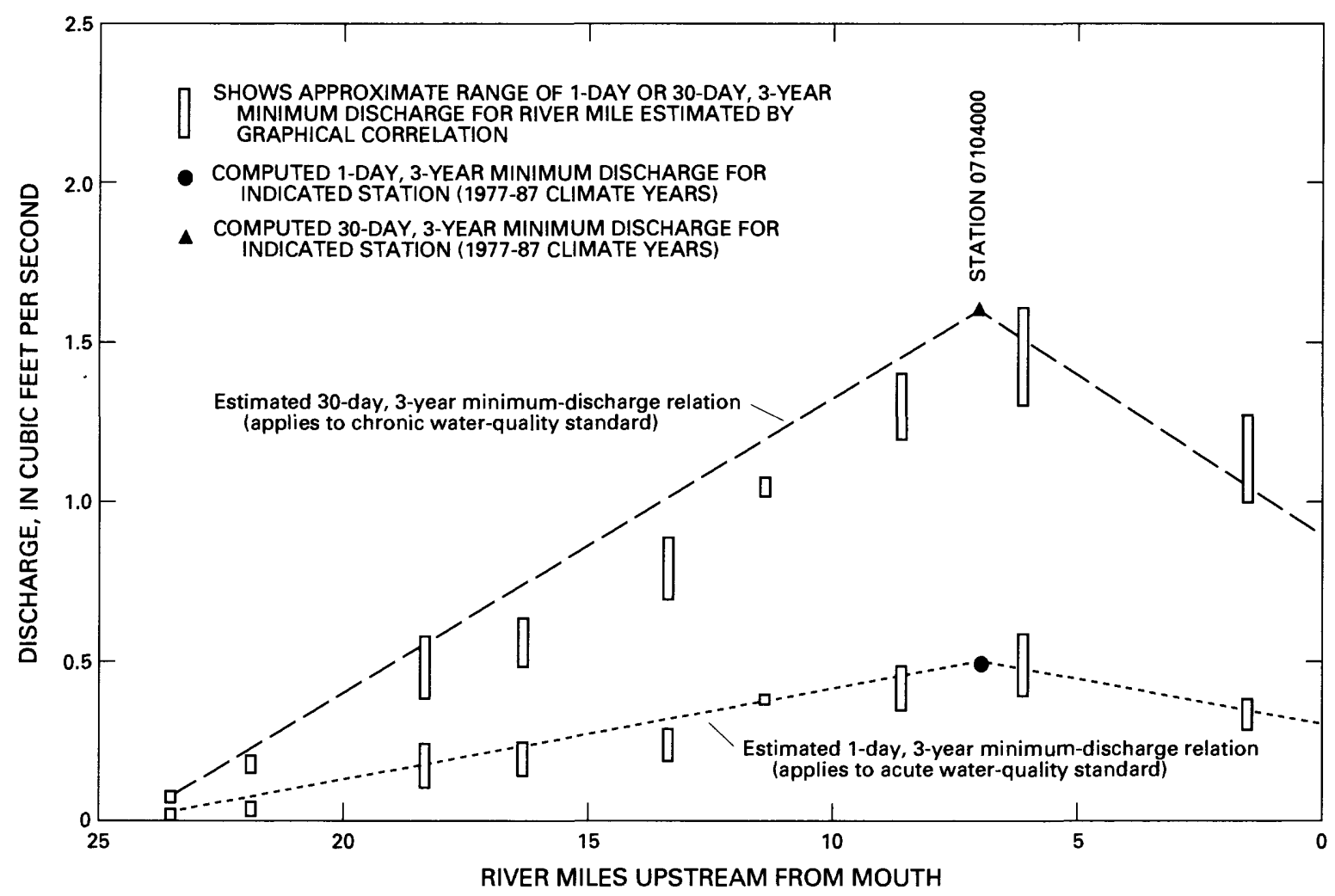

Figure 48.--Estimated 1-day and 30-day, 3-year minimum-discharge relations to be used in simulations of summer stream reach for Monument Creek.

The minimum-discharge relations for the summer stream reach (figs . 48-50) were estimated for a climate-year basis. Because discharges in Monument and Fountain Creeks usually are smallest sometime between June and October, the yearly minimum discharge corresponds to the June-October seasonal minimum discharge. However, minimum-discharge relations for the winter stream reach need to be estimated on a November-March seasonal basis because the minimum discharges during this period are different than the yearly minimum discharges. 


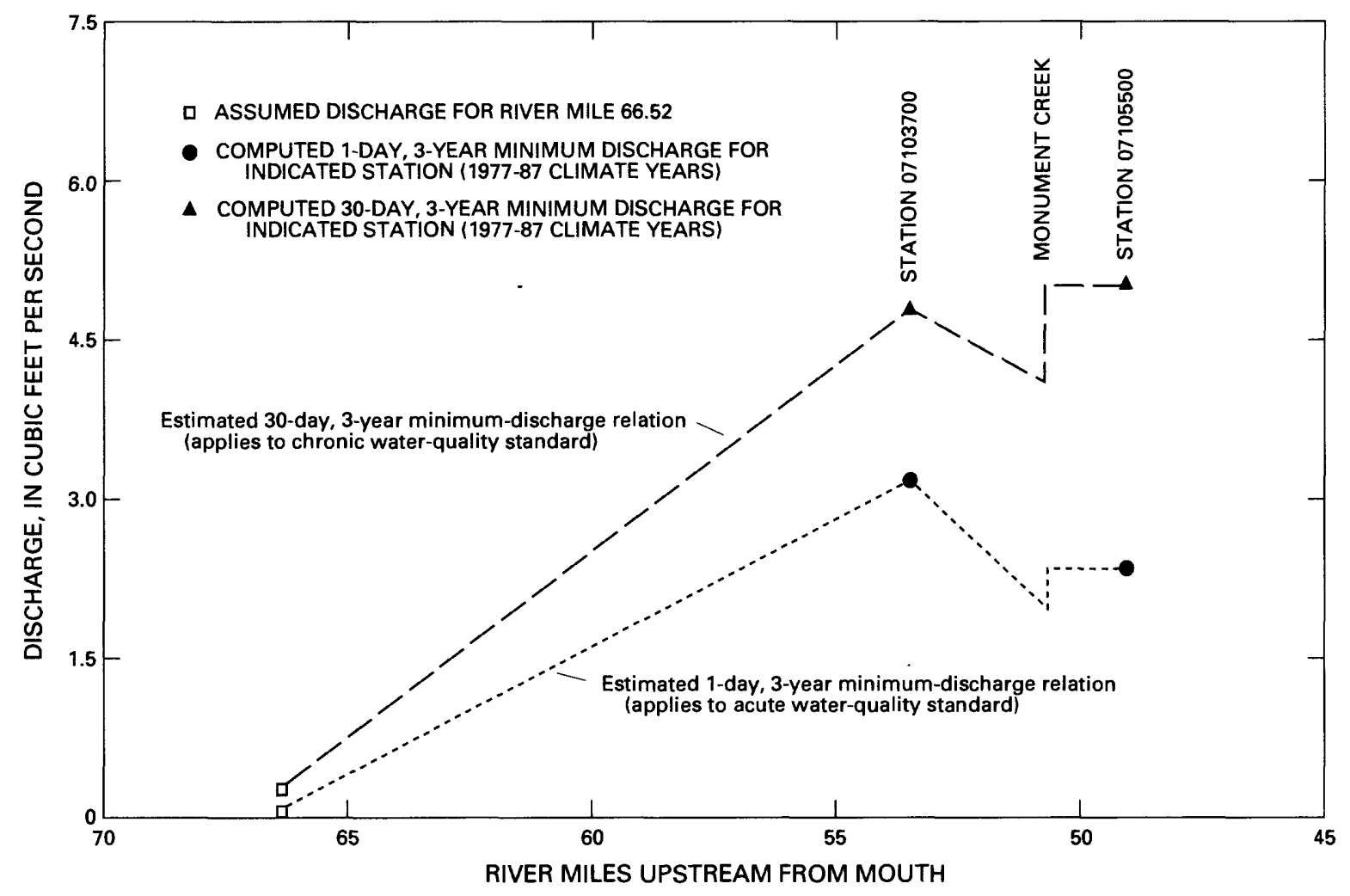

Figure 49.--Estimated 1-day and 30-day, 3-year minimum-discharge relations to be used in simulations of summer stream reach for upper Fountain Creek.

Seasonal $B Q 30,3$ and $B Q 1,3$ currently (1989) cannot be computed by the biologically based method (L.A. Rossman, U.S. Environmental Protection Agency, oral commun., 1989). Comparison of the biologically based $B Q 30,3$ and the statistically based $Q 7,10$ for gaging stations showed some similarity, as did the $B Q 1,3$ and the statistical based 1-day, 10-year minimum discharge (hereinafter referred to as $Q 1,10$ ) (table 17). The statistically based annual minimum discharges (table 17) were computed by a U.S. Geological Survey computer program (Hutchison, 1975) that performs the frequency analysis. Because of these similarities and because the State water-quality regulations adopted in October 1988 indicate that a statistically based minimum discharge equivalent to a biologically based minimum discharge may be used in application of the water-quality standards (Colorado Department of Health, 1988a, p. 24), seasonal $Q 7,10$ and $Q 1,10$ were used to estimate seasonal minimum discharge relations for the winter stream reach. 


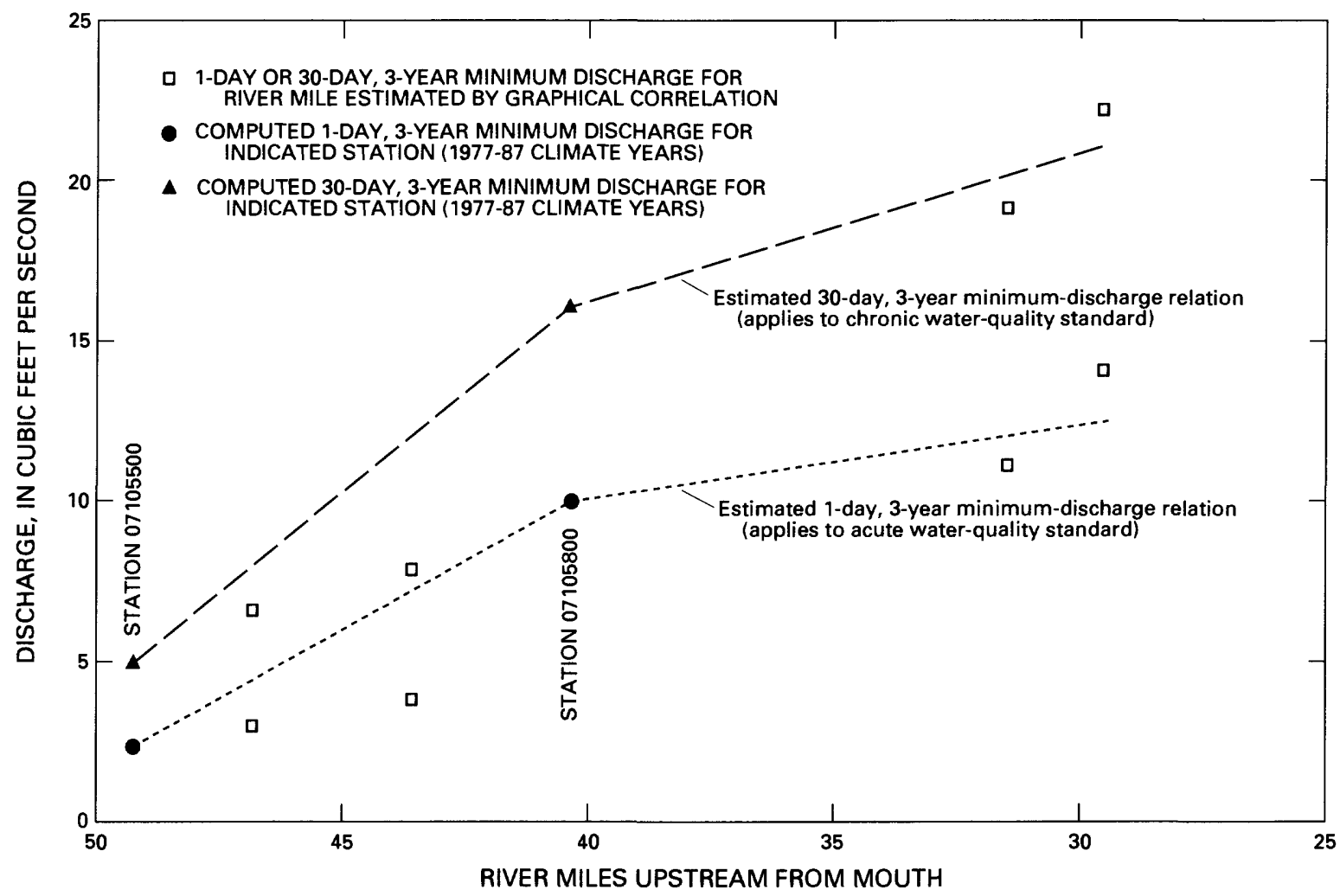

Figure 50.--Estimated 1-day and 30-day, 3-year minimum-discharge relations to be used in simulations of summer stream reach for middle Fountain Creek.

Seasonal minimum-discharge relations were estimated for the winter stream reach using the statistically computed $Q 1,10$ and $Q 7,10$ for stations 07105500, 07105800,07106300 , and 07106500 (fig. 1). The statistically based minimum discharges for the November-March period also were computed by the computer program (Hutchison, 1975) used for computation of the annual minimum discharges. The computed $Q 1,10$ and $Q 7,10$ for the four stations are shown in figure 51 together with the estimated minimum-discharge relations; linear relations also were estimated. For the winter stream reach then, the estimated Q1,10 minimum-discharge relation applies to the acute water-quality standard, and the estimated $Q 7,10$ minimum-discharge relation applies to the chronic water-quality standard. 


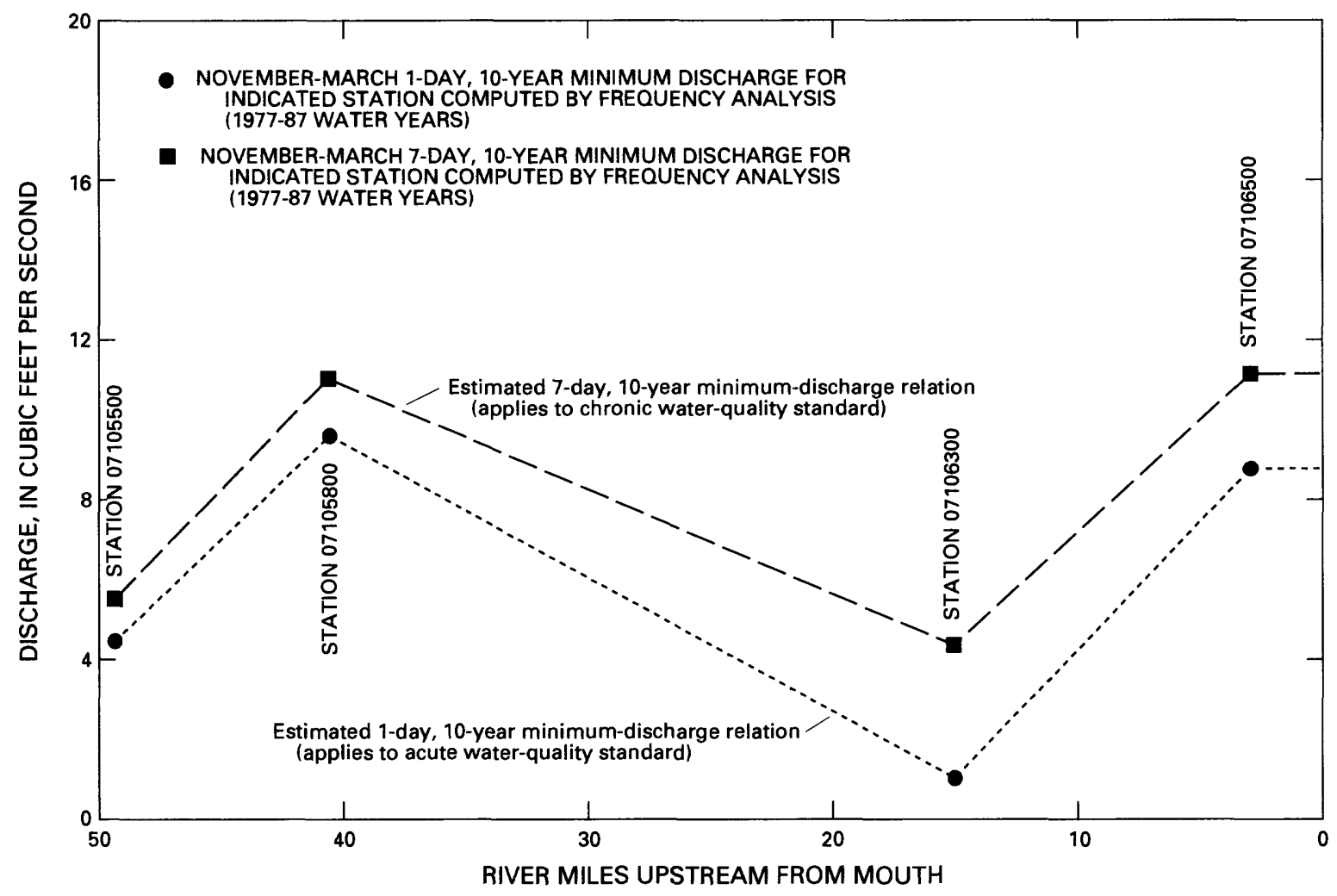

Figure 51.--Estimated 1-day and 7-day, 10-year minimum-discharge relations to be used in simulations of winter stream reach for middle and lower Fountain Creek.

\section{Application of Minimum Discharges}

When using the minimum discharge relations (figs. 48-51) during a simulation, it is assumed that discharge in tributary streams is zero. This assumption is made because: (1) The minimum discharge (such as Q7,10 or $B Q 1,3$ ) cannot be reliably estimated for most tributaries of Monument and Fountain Creeks because discharge records are not available; (2) frequency analysis of the discharge records for tributary streams that were available indicated that the computed minimum discharges were zero or near zero; and (3) the sets of discharge measurements made during minimum-discharge periods also indicated that discharge in tributary streams was zero or near zero. 
Therefore, in a model simulation, the minimum discharges in Monument and Fountain Creeks are simulated by the use of ground-water discharge and recharge except for the estimated minimum discharge at the beginning of the stream section being simulated. Ground-water discharge and recharge are adjusted until the simulated discharge at downstream points approximates the appropriate minimum-discharge relation (figs. 48-51). The adjustments are made without considering discharge from any WWTF located in the stream section; discharge from any WWTF is in addition to the minimum discharge. Water-quality characteristics for ground-water discharge that were estimated for the calibration and verification simulations (see "Preparation of WaterQuality Data for Model Input" section of this report) also are used in the simulations.

The estimated minimum discharges provide an estimate of the quantity of natural discharge available during a minimum-discharge period for a specified number of days and recurrence interval (such as $B Q 1,3$ ). In an application of the model, the simulated discharges will consist of the estimated minimum discharges (from figures 48-51), plus the discharge from any WWT''s considered in the simulation, minus the discharge at any diversions considered in the simulation. Therefore, the simulated discharges usually will not be substantially different from the discharges in the calibration and verification simulations.

When using the estimated minimum-discharge relations one needs to keep in mind that the relations are subject to some error due to the methods used. Although this error was not quantified, on the basis of the methods and data available, the minimum-discharge relations that were estimated are considered reasonable for purposes of application of the model to evaluate the present and projected effects of wastewater discharges on Monument and Fountain Creeks. In addition, the value of a computed minimum discharge, whether statistically based or biologically based, can change depending on the number of years of discharge record available for a gaging station. Consequently, the estimated relations may change somewhat after 1 or more years, depending on how the yearly minimum-discharge periods affect computation of the longterm minimum discharge.

\section{MODEL SIMULATIONS}

Various wastewater-management alternatives for Monument Creek and middle Fountain Creek were simulated during the study; no simulations were made for upper and lower Fountain Creeks. The simulations for Monument Creek were made independently from the simulations for middle Fountain Creek. Numerous simulations were made in each case; however, only three selected simulations are presented in this report for each stream section. The simulations presented may not necessarily represent likely future wastewater-management alternatives for a particular stream section. Presentation of the simulations primarily is for purposes of illustrating how the model can be used to aid in the management of wastewater. 
The simulations for Monument and middle Fountain Creeks were made for an assumed minimum-discharge period during July. Therefore, the reaction coefficients determined for the summer stream reach (table 12) were used in the simulations. Also, it was assumed that the acute water-quality standards were to be met, so the $\mathrm{BQ} 1,3$ minimum discharges for Monument Creek (fig. 48) and middle Fountain Creek ( $f i g .50$ ) were used in the simulations. Only the sites specified in the following discussions were included in the model input for the simulations. The numerous tributaries included in the input for the calibration and verification simulations (table 9) were not used in the example simulations (see "Application of Minimum Discharges" section of this report).

\section{Monument Creek}

Model simulations for Monument Creek were made during the study to aid the Upper Monument Water-Quality Management Agency in development of a wasteload-allocation plan for the WWTF's along Monument Creek. Development of this plan primarily considered the Tri-Lakes, Forest Lakes/Triview, and Donala WWT''s (table 3, sites MT23.67, MT19.66, and MT18.37). The U.S. Air Force Academy WWTF (table 3, site MT13.43), which has a re-use program for its wastewater and usually does not discharge to Monument Creek, was included in the model simulations but was not included in the wasteload-allocation planning; Academy WWTF (table 3, site MT17.45), which does not discharge directly into Monument Creek and has a small discharge volume, was not included in the model simulation or the wasteload-allocation planning (Dick Haymond, Upper Monument Water-Quality Management Agency, oral commun., December 1988). Site MT13.43 was not discharging during the July 1986 or July 1987 sampling periods, and sites MT19.66 and MT18.37 were not in operation during the sampling periods; hence, no wastewater-characteristics data for these sites were included in the calibration and verification simulations (table 9). The discharge at site MT18.37 for the verification data set (table 9) was natural streamflow, not wastewater outfall.

Estimated future water-quality data for discharge at sites MT23.67, MT19.66, MT18.37, and MT13.43 were obtained (table 18, simulation 1) for an initial simulation. The projected maximum future discharge rate for each site (table 18) was used in the simulations in conjunction with the $B Q 1,3$ minimum discharge for Monument Creek (fig. 48). Simulated concentrations of selected water-quality constituents by using the simulation 1 data are shown in figure 52. The results indicate that the water-quality standards for nitrite, nitrate, un-ionized ammonia, and DO would not be met for some subreaches of Monument Creek for the assumed discharge and water-quality conditions. 
Table 18.--Average concentrations of water-quality constituents at sites used in example simulations for Monument Creek

[ $\mathrm{ft}^{3} / \mathrm{s}$, cubic feet per second; ${ }^{\circ} \mathrm{C}$, degrees Celsius; mg/L, milligrams per liter]

\begin{tabular}{|c|c|c|c|c|c|c|c|c|c|}
\hline $\begin{array}{l}\text { Sampling- } \\
\text { site } \\
\text { number } \\
\text { (table } 3 \text { ) }\end{array}$ & $\begin{array}{l}\text { Site } \\
\text { name }\end{array}$ & $\begin{array}{c}\text { Discharge } \\
\left(\mathrm{ft}^{3} / \mathrm{s}\right)\end{array}$ & $\begin{array}{l}\text { Temper- } \\
\text { ature } \\
\left({ }^{\circ} \mathrm{C}\right)\end{array}$ & $\begin{array}{c}\text { Total } \\
\text { organic } \\
\text { nitrogen } \\
(\mathrm{mg} / \mathrm{L})\end{array}$ & $\begin{array}{l}\text { Total } \\
\text { ammonia } \\
\text { as ni- } \\
\text { trogen } \\
\text { (mg/L) }\end{array}$ & $\begin{array}{c}\text { Total } \\
\text { nitrite } \\
\text { as ni- } \\
\text { trogen } \\
\text { (mg/L) }\end{array}$ & $\begin{array}{c}\text { Total } \\
\text { nitrate } \\
\text { as ni- } \\
\text { trogen } \\
(\mathrm{mg} / \mathrm{L})\end{array}$ & $\begin{array}{l}\text { 5-day } \\
\text { carbona- } \\
\text { ceous bio- } \\
\text { chemical } \\
\text { oxygen } \\
\text { demand } \\
\text { (mg/L) }\end{array}$ & $\begin{array}{l}\text { Dis- } \\
\text { solved } \\
\text { oxygen } \\
(\mathrm{mg} / \mathrm{L})\end{array}$ \\
\hline
\end{tabular}

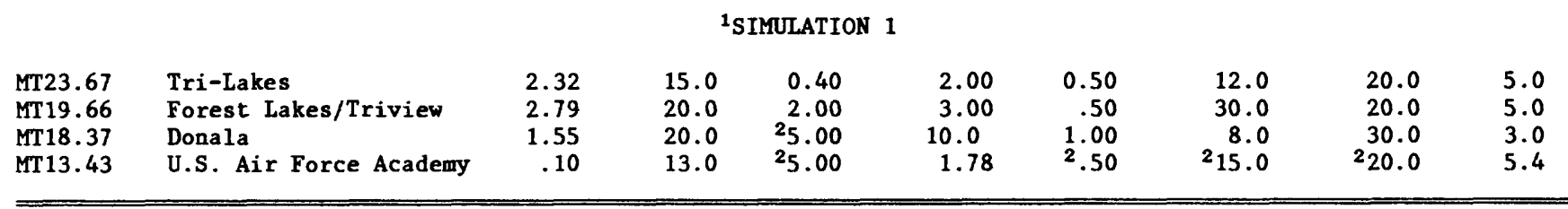

${ }^{3}$ SIMULATION 2

\begin{tabular}{|c|c|c|c|c|c|c|c|c|c|}
\hline $\begin{array}{l}\text { MT23.67 } \\
\text { MT19.66 } \\
\text { MT18.37 } \\
\text { MT13.43 }\end{array}$ & $\begin{array}{l}\text { Tri-Lakes } \\
\text { Forest Lakes/Triview } \\
\text { Donala } \\
\text { U.S. Air Force Academy }\end{array}$ & $\begin{array}{r}2.32 \\
2.79 \\
1.55 \\
.10\end{array}$ & $\begin{array}{l}15.0 \\
20.0 \\
20.0 \\
13.0\end{array}$ & $\begin{array}{l}0.40 \\
2.00 \\
5.00 \\
5.00\end{array}$ & $\begin{array}{l}2.00 \\
2.00 \\
4.00 \\
1.78\end{array}$ & $\begin{array}{r}0.50 \\
.50 \\
1.00 \\
.50\end{array}$ & $\begin{array}{r}9.5 \\
9.5 \\
11.0 \\
15.0\end{array}$ & $\begin{array}{l}20.0 \\
20.0 \\
30.0 \\
20.0\end{array}$ & $\begin{array}{l}5.0 \\
5.0 \\
3.0 \\
5.4\end{array}$ \\
\hline \multicolumn{10}{|c|}{${ }^{3}$ SIMULATION 3} \\
\hline $\begin{array}{l}\text { MT23.67 } \\
\text { MT19.66 } \\
\text { MT18.37 } \\
\text { MT13.43 }\end{array}$ & $\begin{array}{l}\text { Tri-Lakes } \\
\text { Forest Lakes/Triview } \\
\text { Donala } \\
\text { U.S. Air Force Academy }\end{array}$ & $\begin{array}{r}2.32 \\
2.79 \\
1.55 \\
.10\end{array}$ & $\begin{array}{l}15.0 \\
20.0 \\
20.0 \\
13.0\end{array}$ & $\begin{array}{l}0.40 \\
2.00 \\
5.00 \\
5.00\end{array}$ & $\begin{array}{l}2.00 \\
2.00 \\
4.00 \\
1.78\end{array}$ & $\begin{array}{r}0.20 \\
.50 \\
1.00 \\
.50\end{array}$ & $\begin{array}{r}2.0 \\
12.5 \\
13.0 \\
15.0\end{array}$ & $\begin{array}{l}20.0 \\
20.0 \\
30.0 \\
20.0\end{array}$ & $\begin{array}{l}5.0 \\
5.0 \\
3.0 \\
5.4\end{array}$ \\
\hline
\end{tabular}

\footnotetext{
${ }^{1}$ Discharge and water-quality data for simulation 1 provided by the the following sources (except for estimated values):

Site MT23.67: Phillip A. Steininger, Woodmoor Water and Sanitation District, written commun., May 1989.

Site MT19.66: D. Scott Dumler, D. Scott Dumler and Associates, written commun., May 1989.

Site MT18.37: William A. Sheldon, Donala Water and Sanitation District, written commun., August 1989.

Site MT13.43: John C. Patchett, U.S. Air Force Academy, written commun., March 1989. (Discharge was rounded up to $0.10 \mathrm{ft}^{3} / \mathrm{s}$ )

2Estimated value.

${ }^{3}$ Data for simulation 1 adjusted as needed for simulations 2 and 3 to achieve results described in text.
}

Concentrations of ammonia and nitrate were adjusted at sites MT23.67, MT19.66, and MT18.37 in subsequent simulations in an attempt to meet stream water-quality standards while keeping the concentrations of ammonia and nitrate as large as possible. Simulated results for the adjusted concentrations of ammonia and nitrate (table 18, simulation 2) are shown in figure 53. For the simulation 3 data (table 18), it was assumed that treatment of wastewater at site MT23.67 included additional reaction of nitrite and substantial removal of nitrate. The maximum concentrations of nitrate that could be discharged at sites MT19.66 and MT18.37 then were determined, again meeting stream water-quality standards. Results for the simulation by using the simulation 3 data are shown in figure 54. The violations of the water-quality standards for nitrite and DO (figs. 53 and 54) are considered no larger than the uncertainty in the model results; this applies equally well to these constituents in subsequent figures. 

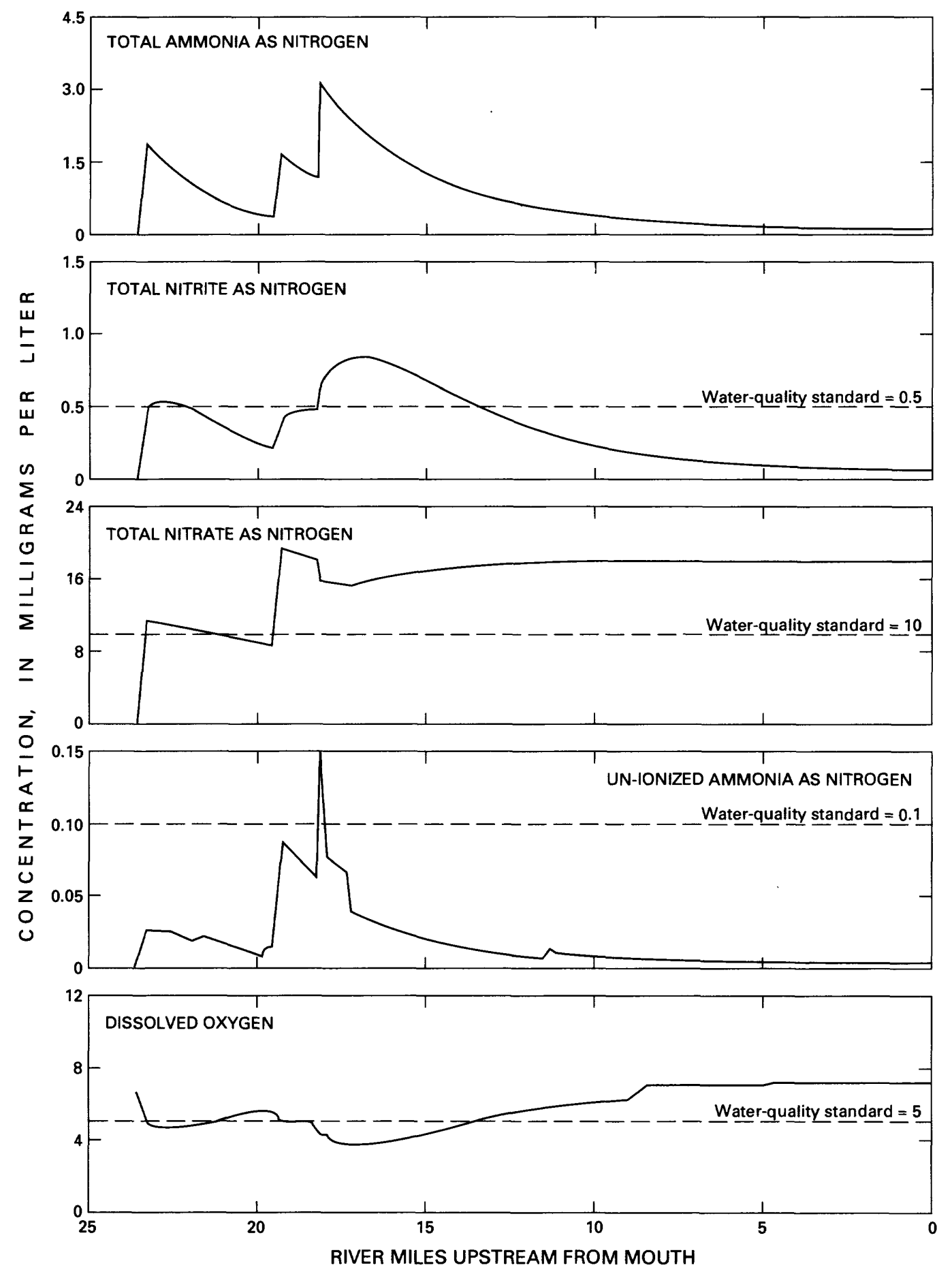

Figure 52.--Simulated concentrations of selected water-quality constituents for Monument Creek using the simulation 1 data. 

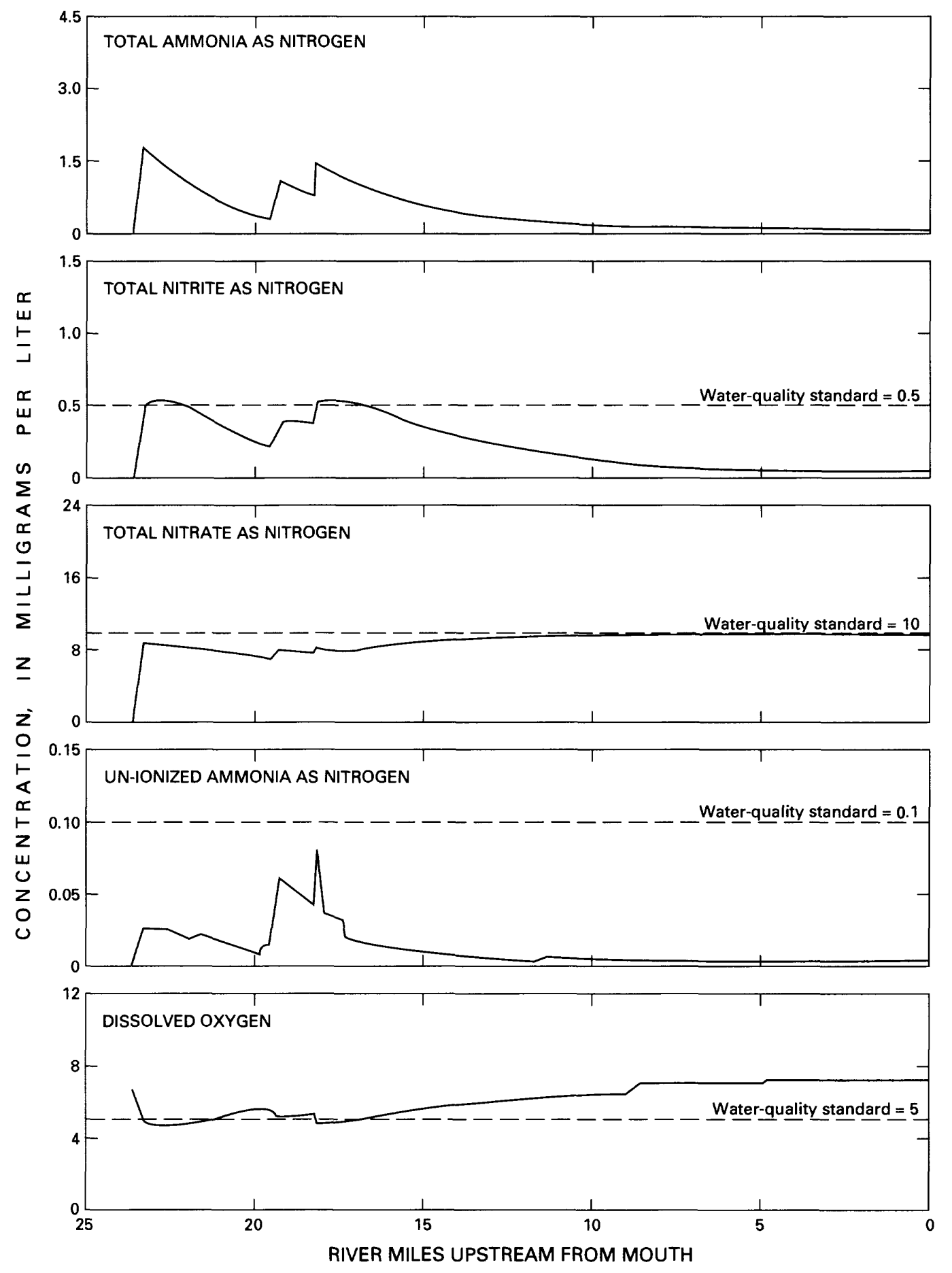

Figure 53.--Simulated concentrations of selected water-quality constituents for Monument Creek using the simulation 2 data. 


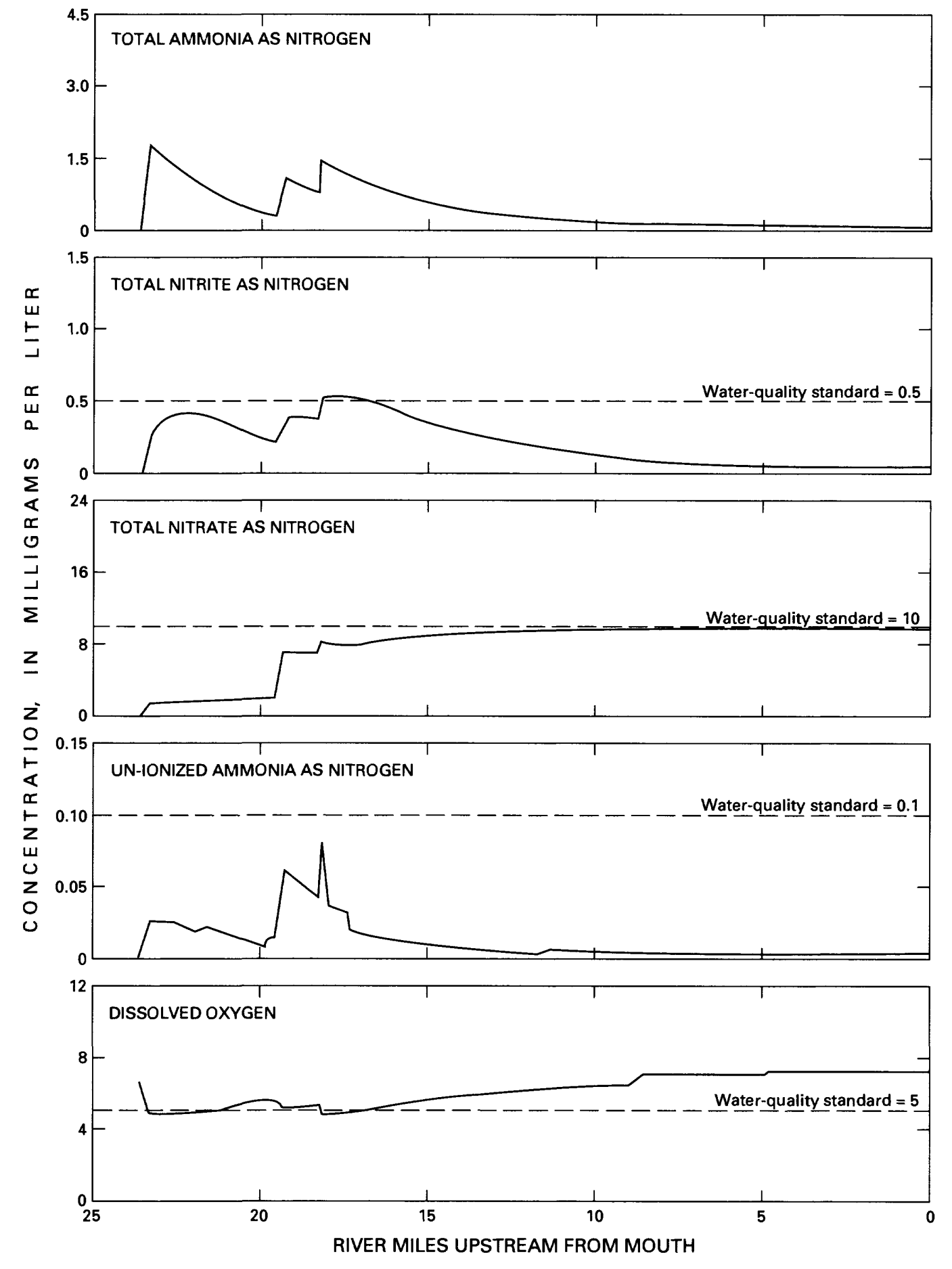

Figure 54.--Simulated concentrations of selected water-quality constituents for Monument Creek using the simulation 3 data. 


\section{Middle Fountain Creek}

Model simulations for middle Fountain Creek were made during the study to aid in estimating the maximum concentrations of ammonia that could be discharged to Fountain Creek by the Colorado Springs, Garden Valley, Security, Widefield, Fort Carson (in Clover Ditch drain), and Fountain WWTF's (table 3, sites FT48.67, FT46.93, FT40.97, FT39.53, FT39.52, and FT34.26) in order to meet a proposed State water-quality standard of $0.1 \mathrm{mg} / \mathrm{L}$ for un-ionized ammonia (Gene Y. Michael, city of Colorado Springs, written commun., May 1989). The proposed standard would apply to Fountain Creek from the confluence with Monument Creek downstream to the mouth.

For the simulations, the $\mathrm{BQ1}, 3$ minimum discharge for middle Fountain Creek (fig. 50) was used; the input data were configured so that no waterquality or discharge effects from Monument and upper Fountain Creeks were included except the required minimum discharge. Also, because of the use of the alternate simulation method (see "Method of Simulating Colorado Springs Wastewater-Treatment Facility" section of this report) and because discharge in Fountain Creek and discharge from site FT48.67 are not completely mixed upstream from about river mile 47.60 , it was assumed (for purposes of the simulations described here only) that water-quality standards would apply from that point downstream.

Initial water-quality data (table 19, simulation 1) for the various WWTF's was based on the average concentrations of water-quality constituents during the July 1986 and July 1987 sampling periods (Kuhn and Ortiz, 1989). The projected maximum discharge rate for each WWTF was used (table 19). Simulated results using the simulation 1 data (table 19) are shown in figure 55; the water-quality standards for nitrite, un-ionized ammonia, and Do would not be met in some subreaches of middle Fountain Creek using the simulation 1 data.

The concentrations of ammonia and nitrate at site FT48.67 were adjusted equally (table 19, simulation 2) in order to approximately meet the proposed un-ionized ammonia standard. Results of the simulation using the adjusted concentrations are shown in figure 56. No changes in concentration of waterquality constituents at the sites (table 19) downstream from site FT48.67 were made for simulation 2 .

The two simulations just described were made assuming no diversion of discharge by any ditches along middle Fountain Creek. However, the Fountain Mutual Canal and Chilcotte Ditch (table 3, sites FT48.66 and FT39.08) can divert large amounts of discharge at times. A simulation (table 19, simulation 3) was made assuming diversions of $45 \mathrm{ft}^{3} / \mathrm{s}$ at site $\mathrm{FT} 48.66$ and $35 \mathrm{ft}^{3} / \mathrm{s}$ at site FT39.08 to evaluate the effects of diversions on water-quality standards. In addition, the concentration of ammonia at site FT34.26 was increased (table 19, simulation 3) to determine how a larger ammonia concentration there together with the upstream diversions of discharge would affect concentrations of un-ionized ammonia in Fountain Creek downstream from that site. Results of the simulation using the diversions and larger concentration of ammonia at site FT34.26 are shown in figure 57. 
Table 19.--Average concentrations of water-quality constituents at sites used in example simulations for middle Fountain Creek

[ft ${ }^{3} / \mathrm{s}$, cubic feet per second; ${ }^{\circ} \mathrm{C}$, degrees Celsius; mg/L, milligrams per liter]

\begin{tabular}{|c|c|c|c|c|c|c|c|c|c|}
\hline $\begin{array}{l}\text { Sampling- } \\
\text { site } \\
\text { number } \\
\text { (table } 3 \text { ) }\end{array}$ & $\begin{array}{l}\text { Site } \\
\text { name }\end{array}$ & $\begin{array}{c}\text { Discharge }{ }^{1} \\
\left(\mathrm{ft}^{3} / \mathrm{s}\right)\end{array}$ & $\begin{array}{l}\text { Temper- } \\
\text { ature } \\
\left({ }^{\circ} \mathrm{C}\right)\end{array}$ & $\begin{array}{c}\text { Total } \\
\text { organic } \\
\text { nitrogen } \\
(m g / L)\end{array}$ & $\begin{array}{c}\text { Total } \\
\text { ammonia } \\
\text { as ni- } \\
\text { trogen } \\
(m g / L)\end{array}$ & $\begin{array}{c}\text { Total } \\
\text { nitrite } \\
\text { as ni- } \\
\text { trogen } \\
(\mathrm{mg} / \mathrm{L})\end{array}$ & $\begin{array}{c}\text { Total } \\
\text { nitrate } \\
\text { as ni- } \\
\text { trogen } \\
(m g / L)\end{array}$ & $\begin{array}{l}\text { 5-day } \\
\text { carbona- } \\
\text { ceous bio- } \\
\text { chemical } \\
\text { oxygen } \\
\text { demand } \\
(\mathrm{mg} / \mathrm{L})\end{array}$ & $\begin{array}{l}\text { Dis- } \\
\text { solved } \\
\text { oxygen } \\
(\mathrm{mg} / \mathrm{L})\end{array}$ \\
\hline
\end{tabular}

\section{${ }^{2}$ SIMULATION 1}

\begin{tabular}{|c|c|c|c|c|c|c|c|c|c|}
\hline $\begin{array}{l}\text { FT48.67 } \\
\text { FT46.93 } \\
\text { FT40.97 }\end{array}$ & $\begin{array}{l}\text { Colorado Springs } \\
\text { Garden Valley } \\
\text { Security }\end{array}$ & $\begin{array}{r}65.0 \\
.17 \\
3.71\end{array}$ & $\begin{array}{l}19.9 \\
18.5 \\
22.1\end{array}$ & $\begin{array}{l}5.18 \\
5.35 \\
3.33\end{array}$ & $\begin{array}{l}16.9 \\
5.65 \\
22.0\end{array}$ & $\begin{array}{r}0.02 \\
3.55 \\
.47\end{array}$ & $\begin{array}{l}0.05 \\
12.0 \\
.11\end{array}$ & $\begin{array}{r}11.0 \\
2.8 \\
11.0\end{array}$ & $\begin{array}{l}2.8 \\
3.7 \\
5.4\end{array}$ \\
\hline $\begin{array}{l}\text { FT39.53 } \\
\text { FT39.52 } \\
\text { FT34.26 }\end{array}$ & $\begin{array}{l}\text { Widefield } \\
\text { Fort Carson } \\
\text { Fountain }\end{array}$ & $\begin{array}{l}3.87 \\
4.56 \\
2.01\end{array}$ & $\begin{array}{l}20.8 \\
21.9 \\
22.5\end{array}$ & $\begin{array}{r}2.58 \\
2.05 \\
12.7\end{array}$ & $\begin{array}{l}9.48 \\
4.32 \\
1.83\end{array}$ & $\begin{array}{r}.65 \\
1.10 \\
.78\end{array}$ & $\begin{array}{r}.66 \\
5.12 \\
.12\end{array}$ & $\begin{array}{r}5.7 \\
6.4 \\
13.0\end{array}$ & $\begin{array}{l}4.6 \\
5.4 \\
3.4\end{array}$ \\
\hline
\end{tabular}

\begin{tabular}{|c|c|c|c|c|c|c|c|c|c|}
\hline \multicolumn{10}{|c|}{${ }^{3}$ SIMULATION 2} \\
\hline $\begin{array}{l}\text { FT48.67 } \\
\text { FT46.93 } \\
\text { FT40.97 }\end{array}$ & $\begin{array}{l}\text { Colorado Springs } \\
\text { Garden Valley } \\
\text { Security }\end{array}$ & $\begin{array}{r}65.0 \\
.17 \\
3.71\end{array}$ & $\begin{array}{l}19.9 \\
18.5 \\
22.1\end{array}$ & $\begin{array}{l}5.18 \\
5.35 \\
3.33\end{array}$ & $\begin{array}{r}4.50 \\
5.65 \\
22.0\end{array}$ & $\begin{array}{r}0.02 \\
3.55 \\
.47\end{array}$ & $\begin{array}{r}12.4 \\
12.0 \\
.11\end{array}$ & $\begin{array}{r}11.0 \\
2.8 \\
11.0\end{array}$ & $\begin{array}{l}2.8 \\
3.7 \\
5.4\end{array}$ \\
\hline $\begin{array}{l}\text { FT39.53 } \\
\text { FT39.52 } \\
\text { FT34. } 26\end{array}$ & $\begin{array}{l}\text { Widefield } \\
\text { Fort Carson } \\
\text { Fountain }\end{array}$ & $\begin{array}{l}3.87 \\
4.56 \\
2.01\end{array}$ & $\begin{array}{l}20.8 \\
21.9 \\
22.5\end{array}$ & $\begin{aligned} 2.58 \\
2.05 \\
12.7\end{aligned}$ & $\begin{array}{l}9.48 \\
4.32 \\
1.83\end{array}$ & $\begin{array}{r}.65 \\
1.10 \\
.78\end{array}$ & $\begin{array}{r}.66 \\
5.12 \\
.12\end{array}$ & $\begin{array}{r}5.7 \\
6.4 \\
13.0\end{array}$ & $\begin{array}{l}4.6 \\
5.4 \\
3.4\end{array}$ \\
\hline \multicolumn{10}{|c|}{${ }^{4}$ SIMULATION 3} \\
\hline $\begin{array}{l}\text { FT48.67 } \\
\text { FT46.93 } \\
\text { FT40.97 }\end{array}$ & $\begin{array}{l}\text { Colorado Springs } \\
\text { Garden Valley } \\
\text { Security }\end{array}$ & $\begin{array}{r}65.0 \\
.17 \\
3.71\end{array}$ & $\begin{array}{l}19.9 \\
18.5 \\
22.1\end{array}$ & $\begin{array}{l}5.18 \\
5.35 \\
3.33\end{array}$ & $\begin{array}{l}4.50 \\
5.65 \\
22.0\end{array}$ & $\begin{array}{r}0.02 \\
3.55 \\
.47\end{array}$ & $\begin{array}{r}12.4 \\
12.0 \\
.11\end{array}$ & $\begin{array}{r}11.0 \\
2.8 \\
11.0\end{array}$ & $\begin{array}{l}2.8 \\
3.7 \\
5.4\end{array}$ \\
\hline $\begin{array}{l}\text { FT39.53 } \\
\text { FT39.52 } \\
\text { FT34.26 }\end{array}$ & $\begin{array}{l}\text { Widefield } \\
\text { Fort Carson } \\
\text { Fountain }\end{array}$ & $\begin{array}{l}3.87 \\
4.56 \\
2.01\end{array}$ & $\begin{array}{l}20.8 \\
21.9 \\
22.5\end{array}$ & $\begin{array}{r}2.58 \\
2.05 \\
12.7\end{array}$ & $\begin{array}{l}9.48 \\
4.32 \\
20.0\end{array}$ & $\begin{array}{r}.65 \\
1.10 \\
.78\end{array}$ & $\begin{array}{r}.66 \\
5.12 \\
.12\end{array}$ & $\begin{array}{r}5.7 \\
6.4 \\
13.0\end{array}$ & $\begin{array}{l}4.6 \\
5.4 \\
3.4\end{array}$ \\
\hline
\end{tabular}

${ }^{1}$ Maximum projected discharge rates provided by Gene Y. Michael, city of Colorado Springs, oral commun., May 1989.

2Water-quality data for simulation 1 is average of data for July 1986 and July 1987 24-hour sampling periods (Kuhn and Ortiz, 1989).

${ }^{3}$ Data for simulation 1 adjusted as needed for simulation 2 to achieve results described in text.

${ }^{4}$ Data for simulation 3 is the same as data for simulation 2 except that discharge is diverted at sites FT48.66 and FT39.08 and concentration of ammonia is increased at site FT34.26. 

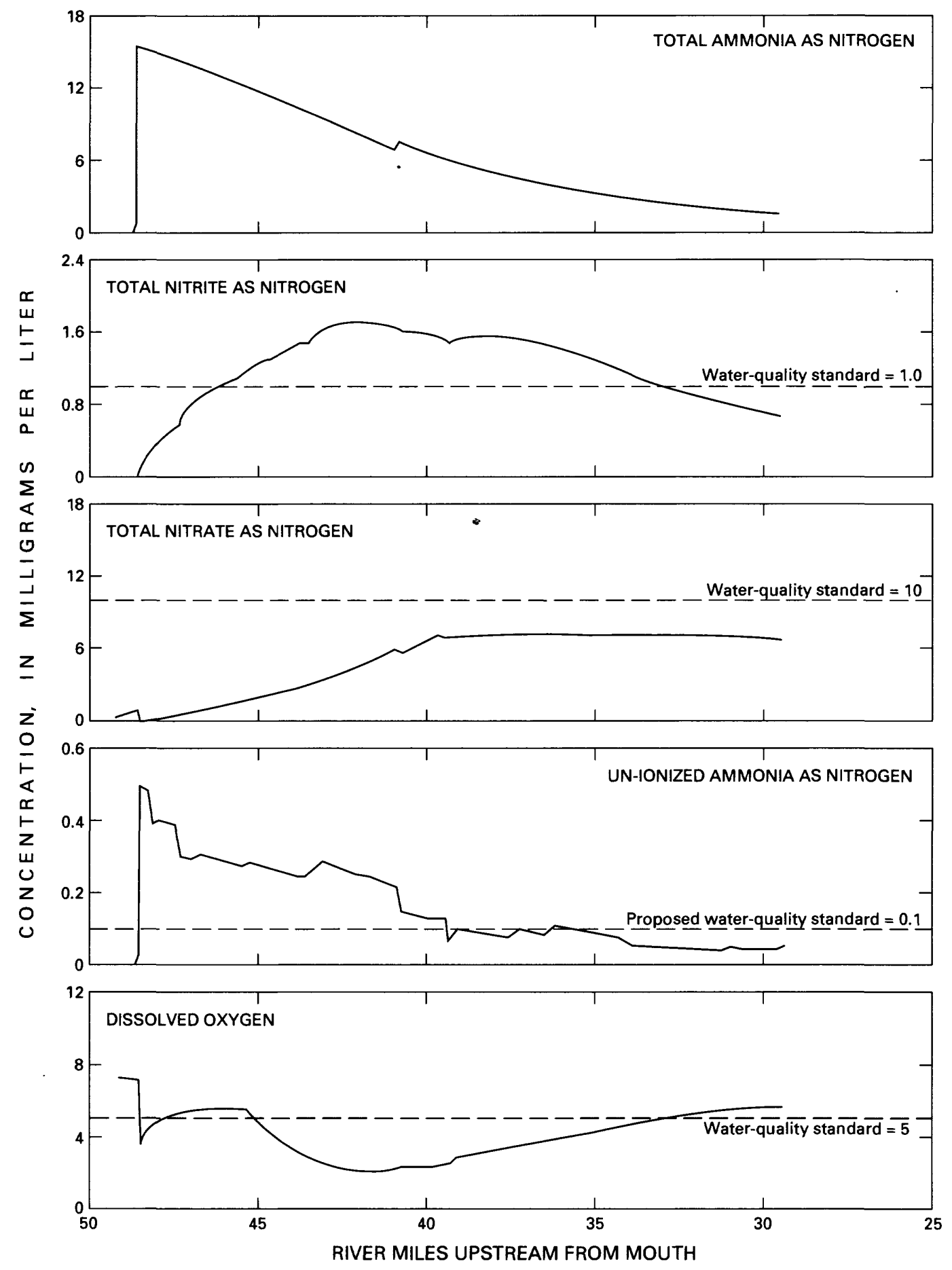

Figure 55.--Simulated concentrations of selected water-quality constituents for middle Fountain Creek using the simulation 1 data. 

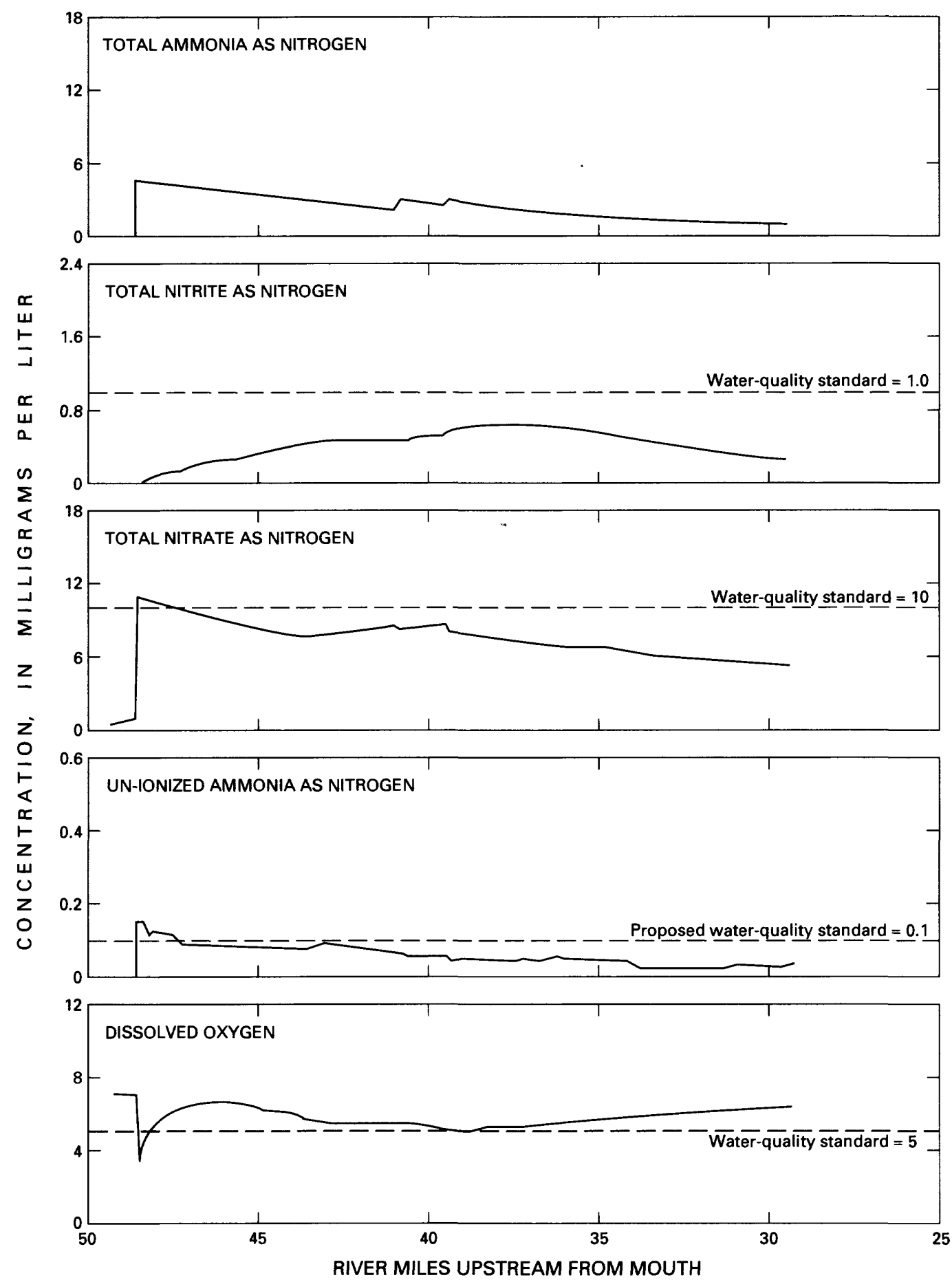

Figure 56.--Simulated concentrations of selected water-quality constituents for middle Fountain Creek using the simulation 2 data. 

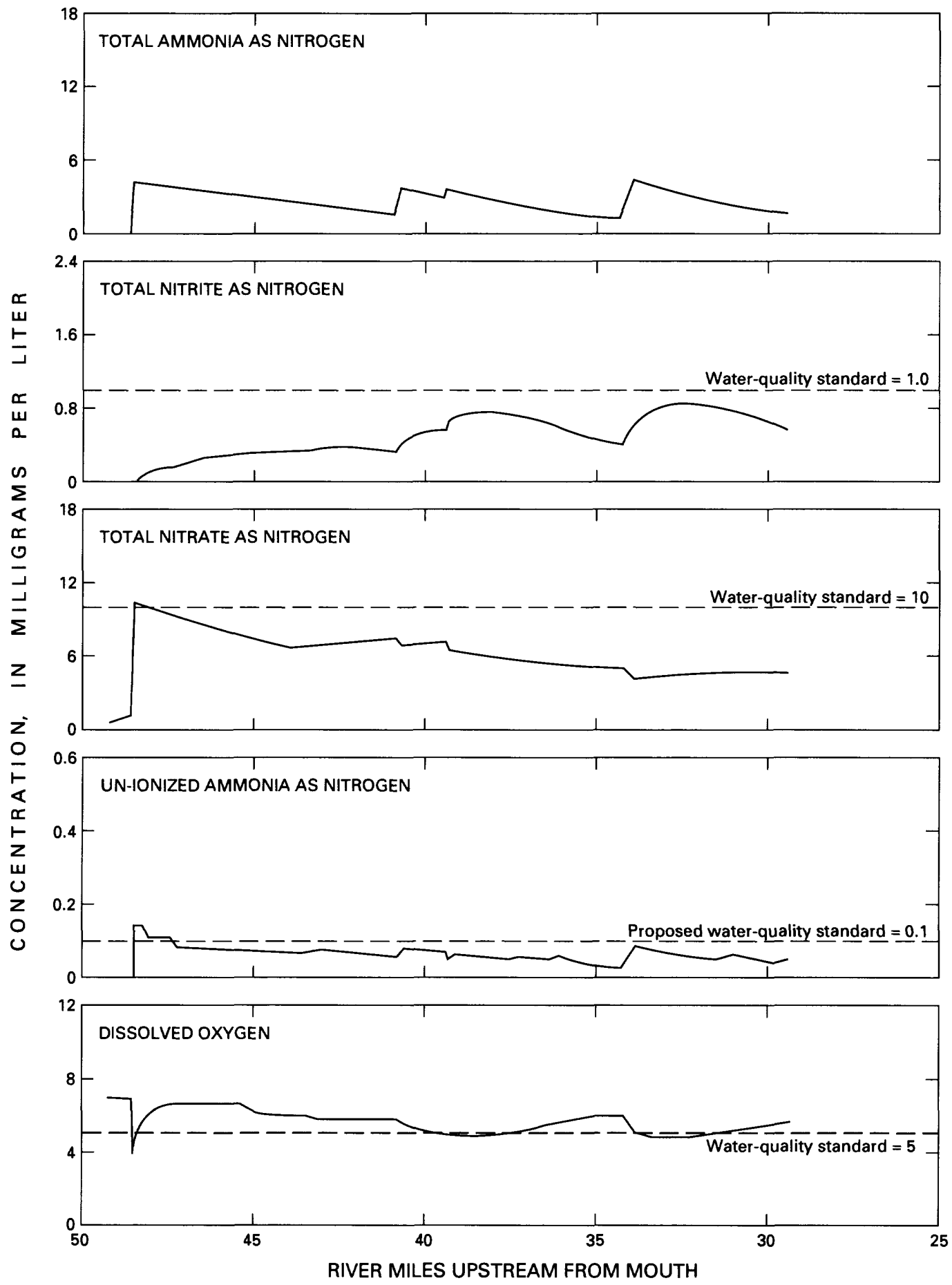

Figure 57.--Simulated concentrations of selected water-quality constituents for middle Fountain Creek using the simulation 3 data. 


\section{LIMITATIONS OF WATER-QUALITY MODEL AND FUTURE DATA NEEDS}

Use of any model to simulate a natural system has limitations because: (1) the variability in the natural system may not be fully represented in the model; (2) every natural process in the system may not be represented in the model; (3) the processes that are represented may not be calibrated accurately; and (4) inaccuracy in calibration and verification input data. The following paragraphs present a general analysis of the limitations in applying the QUAL2E model to Monument and Fountain Creeks. The analysis will be qualitative in content because analysis of the quantitative limitations is difficult due to the large range in concentration of the waterquality constituents and the variability in the system.

A basic assumption in use of the QUAL2E model is that of steady-state conditions, or that discharge and concentration were constant over the dielsampling periods. The assumption of steady-state conditions generally was valid for Monument, upper Fountain, and lower Fountain Creeks. However, variation in the rate of discharge from the Colorado Springs WWTF results in noticeable variations in discharge and concentration of water-quality constituents in middle Fountain Creek.

The effect of the non-steady conditions on the calibrations and verifications has not been determined. The variation in rate of discharge from the Colorado springs WWTF is not large for about two-thirds of the day (Laird Johnson, City of Colorado Springs, written commtn., 1985), probably decreasing any effect of non-steady conditions. Because of this and because there were no unexpected storms or releases of wastewater during the dielsampling periods, any effect of non-steady conditions should not be a substantial limitation in use of the model. The user of the model, however, needs to remember that any model results are an estimated average daily discharge or concentration.

Use of the model also is based on the assumption that stream discharge in an application simulation is similar to stream discharge in the calibration and verification simulations. Total stream discharge in middle Fountain Creek assumed for the example simulations was about $70 \mathrm{ft} / \mathrm{s}[\mathrm{BQ} 1,3$ (fig. 50) plus any WWTF discharges (table 19)]; this discharge was similar to the stream discharges in the calibration and verification simulations (fig. 4). Total stream discharge in Monument Creek assumed in the example simulations was about $7.3 \mathrm{ft}^{3} / \mathrm{s}$ ( $\mathrm{fig} .48$; table 18 ); this discharge was considerably less than the stream discharges in the calibration and verification simulations. However, generally uniform reaction coefficients (tables 12 and 13) were determined for Monument Creek, as well as for Fountain Creek, even though there was considerable variation in discharge from upstream sites to downstream sites (figs. 3-5). Therefore, some differences in stream discharge between an application simulation and the calibration and verification simulations should not be a substantial limitation in use of the model. Application of the model to upper Fountain Creek, however, is limited because of the zero-discharge subreach. The limitations are described in the "Upper Fountain Creek" results section of this report. 
For Monument Creek, the model has limitations in simulation of ammonia and nitrite because of the poor calibrations for these two constituents. The water-quality characteristics of the Tri-Lakes WWTF outfall for the calibration were considerably different from those for the verification (table 9). Moreover, the estimated water quality used for the model simulations (table 18) was different from the measured sample sets (table 9 , site MT23.67). The Tri-Lakes WWTF was being modified during 1989-90 and two additional WWTF's (table 2, sites MT19.66 and MT18.37) soon will discharge to Monument Creek. Because of these reasons, additional data sets should be obtained for Monument Creek to provide additional calibration and verification of ammonia and nitrite. Until then, the model results for ammonia and nitrite for Monument Creek need to be viewed with caution; the results for the other constituents do not have this limitation.

For middle and lower Fountain Creeks, limitations in use of the model generally are small because the calibrations and verifications of most waterquality constituents were acceptable (tables 15 and 16). The primary limitations will be for subreach 37 (between river miles 48.67 and 48.42) because of the use of the alternate method of simulating the Colorado Springs WWTF. The estimated effects of wastewater on this reach will not be representative of actual conditions in Fountain Creek, and the results for this reach also should be viewed with caution. However, downstream from about river mile 48.42 the calibration and verification results were representative of measured conditions (table 14) when using the alternate method. Because the alternate method enables use of the model when no data are available for sites FT48.66 and FT48.46 (table 3; fig. 9), the inability to correctly simulate water quality between the two sites is not considered a substantial limitation in use of the model.

\section{SUMMARY}

Recognition that discharge in Monument and Fountain Creeks, two small streams in the vicinity of Colorado Springs and Pueblo, often is predominantly wastewater and the likelihood of future increases in wastewater discharge led local wastewater-treatment agencies to sponser a study to develop, calibrate, and verify a water-quality model for the streams. The study was completed by the U.S. Geological Survey in cooperation with the Pikes Peak Area Council of Governments. The QUAL2E model, a one-dimensiona1, steady-state stream waterquality model, was used in the modeling analysis.

One stream reach was established for Monument and Fountain Creeks to evaluate wastewater-discharge effects during summer, especially depletion of dissolved oxygen. Another stream reach was established only for Fountain Creek to evaluate wastewater-discharge effects during winter, especially the possibility of exceeding the water-quality standard of $0.1 \mathrm{mg} / \mathrm{L}$ for un-ionized ammonia in the Arkansas River downstream from Fountain Creek as a result of (1) the ammonia discharged by the Colorado Springs Wastewater-Treatment Facility (WWTF) and (2) the smaller stream nitrification rates during winter. 
Each stream reach was sampled intensively two times during four 24-hour periods (July 15-16, 1986; December 9-10, 1986; February 10-11, 1987; July 20-21, 1987) to provide the calibration and verification data sets. Waterquality data obtained for tributaries and wastewater outfalls provided the model input data, whereas water-quality data obtained for sites on Monument and Fountain Creeks provided the means to compare simulated water quality to measured water quality.

Prior to calibrating and verifying the model for water-quality constituents, preliminary simulations were made to ensure that estimated discharges and stream temperatures were reasonable. Estimated discharges were adjusted by simulating ground-water discharge or recharge, whereas estimated stream temperatures were adjusted by using climatologic variables.

Water-quality constituents that were calibrated and verified are: total organic nitrogen, total ammonia as nitrogen, total nitrite as nitrogen, total nitrate as nitrogen, 5-day carbonaceous biochemical oxygen demand, and dissolved oxygen. For the summer stream reach, the calibration and verification results were acceptable with the following exceptions: (1) Ammonia and nitrite could not be calibrated for Monument Creek, (2) nitrate could not be calibrated for upper Fountain Creek, and (3) nitrite and nitrate could not be verified for middle Fountain Creek. For the winter stream reach, the calibration and verification results were acceptable for all water-quality constituents, except that the ammonia calibration and the organic nitrogen and 5-day carbonaceous biochemical oxygen demand verifications were questionable for the downstream reaches of Fountain Creek.

Capability to estimate concentration of un-ionized ammonia was added to the model. The method uses the model-estimated stream temperatures, simulated concentrations of total ammonia and dissolved solids, and values of $\mathrm{pH}$ for each model subreach specified in the input data. Estimated concentrations of un-ionized ammonia were reasonable except where the errors in simulated total ammonia were large.

Minimum-discharge relations were estimated for the two streams to be used in conjunction with the chronic and acute water-quality standards adopted by the Colorado Department of Health in October 1988. The minimum-discharge relations were estimated by using graphical correlation of discharge measurements, statistically and biologically based minimum discharges for gaging-station sites, and assuming linear changes in discharge between the gaged sites.

Example simulations were made for Monument Creek and middle Fountain Creek by using the reaction coefficients determined for the summer stream reach, the estimated $\mathrm{BQ1}, 3$ minimum discharges, and initial water-quality characteristics data for WWTF sites along Monument and middle Fountain Creek provided by the facility operators. Following an initial simulation, the water-quality data were adjusted differently for two subsequent simulations in order to meet the stream water-quality standards. 
Several modifications were made to the QUAL2E model for the study. The modifications included: (1) Addition of the capability to use a different computational-element length for each subreach, (2) modification of the method used to estimate stream temperature, and (3) addition of a subroutine to estimate concentration of un-ionized ammonia.

\section{REFERENCES CITED}

American Public Health Association, American Water Works Association, and Water Pollution Control Federation, 1985, Standard methods for the examination of water and wastewater (16th ed.): Washington, D.C., $1,268 \mathrm{p}$.

Bauer, D.P., Jennings, M.E., and Miller, J.E., 1979, One-dimensional steadystate stream water-quality model: U.S. Geological Survey Water-Resources Investigations $79-45,215$ p.

Bauer, D.P., Steele, T.D., and Anderson, R.D., 1978, Analysis of waste-load assimilative capacity of the Yampa River, Steamboat Springs to Hayden, Routt County, Colorado: U.S. Geological Survey Water-Resources Investigations 77-119, $69 \mathrm{p}$.

Bennett, J.P., and Rathbun, R.E., 1972, Reaeration in open-channel flow: U.S. Geological Survey Professional Paper 737, 75 p.

Bowie, G.I., Mills, W.B., Porcella, D.B., Campbell, C.I., Pagenkopf, J.R., Rupp, G.I., Johnson, K.M., Chan, P.W.H., and Gherini, S.A., 1985, Rates, constants, and kinetics formulations in surface water quality modeling, second edition: U.S. Environmental Protection Agency Report No. EPA/600/3-85/040, 455 p.

Brown, L.C., and Barnwell, T.0., Jr., 1987, The enhanced stream water-quality models QUAL2E and QUAL2E-UNCAS--Documentation and user manual: Athens, Ga., U.S. Environmental Protection Agency, Environmental Research Laboratory, EPA/600/3-87/007, 189 p.

Cadwallader, T.E., and McDonnell, A.J., 1969, A multivariate analysis of reaeration data: Water Research, v. 3, p. 731-742.

Cain, Doug, 1987, Relations of specific conductance to streamflow and selected water-quality characteristics of the Arkansas River basin, Colorado: U.S. Geological Survey Water-Resources Investigations Report 87-4041, $93 \mathrm{p}$.

Cain, Doug, and Edelmann, Patrick, 1986, A reconnaissance water-quality appraisal of the Fountain Creek alluvial aquifer between Colorado Springs and Pueblo, Colorado, including trace elements and organic constituents: U.S. Geological Survey Water-Resources Investigations Report 86-4085, 45 p.

Cain, Doug, Baldridge, Duaina, and Edelmann, Patrick, 1980, Wasteassimilation capacity of the Arkansas River in Pueblo County, Colorado, as it relates to water-quality guidelines and stream classification: U.S. Geological Survey Water-Resources Investigations 80-82, $104 \mathrm{p}$.

Churchill, M.A., Elmore, H.L., and Buckingham, R.A., 1962, The prediction of stream reaeration rates: American Society of Civil Engineers, Journal of the Sanitary Engineering Division, v. 88, no. SA-4, p. 1-46. 
Colorado Department of Health, 1979, Regulations establishing basic standards and an antidegradation standard, and establishing a system for classifying state waters, for assigning standards, and for granting temporary modifications: Denver, Water Quality Control Commission, $41 \mathrm{p}$. $1988 \mathrm{a}$, The basic standards and methodologies for surface water, notice of final adoption: Denver, Water-Quality Control Commission, 89 p. 1988b, Classification and numeric standards for the entire Arkansas River basin: Denver, Water Quality Control Commission, 1 volume.

Edelmann, Patrick, 1990, Water quality of Fountain and Monument Creeks, southcentral Colorado, with emphasis on relation of water quality to stream classifications: U.S. Geological Survey Water-Resources Investigations Report 88-4132, 99 p.

Edelmann, Patrick, and Cain, Doug, 1985, Sources of water and nitrogen to the Widefield aquifer, southwestern El Paso County, Colorado: U.S. Geological Survey Water-Resources Investigations Report 85-4162, 81 p.

European Inland Fisheries Advisory Commission, 1973, Water quality criteria for European freshwater fish--Report on ammonia and inland fisheries: Water Resources Research, v. 7, p. 1011-1022.

Farnsworth, R.K., Thompson, E.S., and Peck, E.L., 1982, Evaporation atlas for the contiguous 48 United States: Washington, D.C., National Oceanic and Atmospheric Administration Technical Report NWS 33, 26 p.

Farrow, John, 1986, Special study on water-quality characteristics and wasteload assimilative capacity of Monument Creek, E1 Paso County, 1985-86: Denver, Colorado Department of Health, Water Quality Control Division, 15 p.

Fishman, M.J., and Friedman, L.C., eds., 1989, Methods for determination of inorganic substances in water and fluvial sediments: U.S. Geological Survey Techniques of Water-Resources Investigations, Book 5, Chapter A1, $545 \mathrm{p}$.

Freeman, W.0., and Schmidt, A.R., 1986, Assessment of low-flow water quality in Richland Creek, Illinois: U.S. Geological Survey Water Resources Investigations Report 86-4323, 95 p.

Freeman, W.0., Schmidt, A.R., and Stamer, J.K., 1986, Assessment of low-flow water quality in the Du Page River, Illinois: U.S. Geological Survey Water-Resources Investigations Report 85-4344, 98 p.

Goddard, K.E., 1980, Calibration and potential uses of a digital water-quality model for the Arkansas River in Pueblo County, Colorado: U.S. Geological Survey Water-resources Investigations Report 80-38, $87 \mathrm{p}$.

Hovis, J.S., and Whittemore, R.C., 1982, The mathematical water-quality model QUAL-II and guidance for its use--Revised version: National Council of the Paper Industry for Air and Stream Improvement, Technical Bulletin no. 391, 1 volume.

Hubbard, E.F., Kilpatrick, F.A., Martens, L.A., and Wilson, J.F., Jr., 1982, Measurement of time of travel and dispersion in streams by dye tracing: U.S. Geological Survey Techniques of Water-Resources Investigations, Book 3, Chapter A9, 44 p.

Hutchison, N.E., compiler, 1975, WATSTORE, National Water Data Storage and Retrieval System, User's guide--volume 1: U.S. Geological Survey Open-File Report 75-426, 791 p.

Iman, R.L., and Conover, W.J., 1983, A modern approach to statistics: New York, John Wiley, 497 p.

Isaacs, W.P., and Gaudy, A.F., 1968, Atmospheric oxygenation in a simulated stream: American Society of Civil Engineers, Journal of the Sanitary Engineering Division, v. 94, no. SA-2, p. 319-344. 
Kilpatrick, F.A., Rathbun, R.E., Yotsukurs, Nobuhiro, Parker, G.W., and DeLong, L.L., 1989, Determination of stream reaeration coefficients by use of tracers: U.S. Geological Survey Techniques of Water Resources Investigations, Book 3, Chapter A18, $52 \mathrm{p}$.

Klein, J.M., and Bingham, D.L., 1975, Water quality, Fountain and Jimmy Camp Valleys, Colorado, 1973: Denver, Colorado Water Conservation Board, Water Resources Circular 26, 27 p.

Krenkel, P.A., and Orlob, G.T., 1963, Turbulent diffusion and the reaeration coefficient: American Society of Civil Engineers Transactions, v. 128, Paper 3491, p. 293-334.

Kuhn, Gerhard, and Ortiz, R.F., 1989, Selected hydrologic data for Fountain Creek and Monument Creek basins, east-central Colorado: U.S. Geological Survey Open-File Report 88-705, 106 p.

Langbein, W.B., and Durum, W.H., 1967, The aeration capacity of stream: U.S. Geological Survey Circular 542, 6 p.

Livingston, R.K., Bingham, D.L., and Klein, J.M., 1975, Appraisal of water resources of northwestern El Paso County, Colorado: Denver, Colorado Water Conservation Board, Water Resources Circular 22, 75 p.

Livingston, R.K., Klein, J.M., and Bingham, D.L., 1976a, Water Sources of E1 Paso County, Colorado: Denver, Colorado Water Conservation Board, Water Resources Circular 32, 85 p. 1976b, Appraisal of water resources of southwestern E1 Paso County, Colorado: Denver, Colorado Water Conservation Board, Water Resources Circular 33, 66 p.

National Oceanic and Atmospheric Administration, 1988a, Local climatological data, annual summary with comparative data, Colorado Springs, Colorado: Asheville, N.C., National Climatic Center, 8 p. $1988 \mathrm{~b}$, Local Climatological data, annual summary with comparative data, Pueblo, Colorado: Asheville, N.C., National Climatic Center, 8 p.

Negulescu, M., and Rojanski, V., 1969, Recent research to determine reaeration coefficient: Water Research, v. 3, no. 3, p. 189-202.

$0^{\prime}$ Connor, D.J., and Dobbins, W.E., 1958, Mechanisms of reaeration in natural streams: American Society of Civil Engineers Transactions, v. 123, p. 641-684.

Owens, M., Edwards, R.W., and Gibbs, J.W., 1964, Some reaeration studies in streams: Oxford, England, International Journal of Air and Water Pollution, v. 8 , no. $8 / 9$, p. 469-486.

Padden, T.J., and Gloyna, E.F., 1971, Simulation of stream processes in a model river: Austin, University of Texas, Center for Research in Water Resources, Technical Report no. 2, 130 p.

Parkhurst, J.D., and Pomeroy, R.D., 1972, Oxygen absorption in streams: American Society of Civil Engineers, Journal of the Sanitary Engineering Division, v. 98, no. SA-1, p. 101-124.

Paulson, C.L., 1989, A new approach to NPDES permitting: Colorado Water Engineering and Management Conference, Fort Collins, Colo., February 1989, Proceedings, p. 93-104.

Pikes Peak Area Council of Governments, 1986, Project Aquarius--Areawide water quality management plan for the Pikes Peak region (E1 Paso and Teller Counties), 1985 update: Colorado Springs, 1 volume.

Rathbun, R.E., 1977, Reaeration coefficients of streams--State-of-the-art: American Society of Civil Engineers, Journal of the Hydraulics Division, v. 103 , no. $\mathrm{HX}-4$, p. 409-424. 
Riggs, H.C., 1968, Frequency curves: U.S. Geological Survey Techniques of Water Resources Investigations, Book 4, Chapter A2, 15 p. 1972, Low-flow investigations: U.S. Geological Survey Techniques of Water Resources Investigations, Book 4, Chapter B1, 18 p.

Sawyer, C.N., and McCarthy, P.L., 1967, Chemistry for sanitary engineers: New York, McGraw-Hill, 518 p.

Skarheim, H.P., 1973, Tables of the fraction of ammonia in the undissociated form for $\mathrm{pH} 6$ to 9, temperature 0-30 degrees Celsius, total dissolved solids $0-3,000 \mathrm{mg} / \mathrm{L}$, and salinity 5-35 $\mathrm{g} / \mathrm{kg}$ : Berkeley University of California, Sanitary Engineering Research Laboratory, SERL Report no. $73-5,33 \mathrm{p}$.

Stewart, J.M., comp., 1987, Summary of water-resources activities of the U.S. Geological Survey in Colorado-Fiscal year 1987: U.S. Geological Survey Open-File Report 87-388, 65 p.

Spahr, N.E., and Blakely, S.R., 1985, Effects of wastewater effluent on the South Platte River from Littleton to Denver: U.S. Geologcial Survey Water-Resources Investigations Report 85-4124, $97 \mathrm{p}$.

Terry, J.E., Morris, E.E., and Bryant, C.T., 1983, Water-quality assessment of White River between Lake Sequoyah and Beaver Reservoir, Washington County Arkansas: U.S. Geological Survey Water-Resources Investigations Report $82-4063,84 \mathrm{p}$.

Terry, J.E., Morris, E.E., Peterson, J.C., and Darling, M.E., 1984, Water-quality assessment of the Illinois River basin, Arkansas: U.S. Geological Survey Water-Resources Investigations Report 83-4092, 263 p.

Thurston, R.V., Russo, R.C., and Emerson, K., 1974, Aqueous ammonia equilibrium--Tabulation of percent un-ionized ammonia: Duluth, Minn., U.S. Environmental Protection Agency, EPA-600/3-79-091, 427 p.

Tsivoglou, E.C., and Neal, L.A., 1976, Tracer measurement of reaeration, Part III. Predicting the reaeration capacity of inland streams: Journal of the Water Pollution Control Federation, v. 48, no. 12, p. 2669-2689.

U.S. Environmental Protection Agency, 1986, Technical guidance manual for performing waste load allocation, bk. VI, design conditions--chapter 1 , stream design flow for steady-state modeling: Washington, D.C., 1 volume.

U.S. Geological Survey, 1979, Water resources data for Colorado--Water year 1978, Volume 1, Missouri River basin, Arkansas River basin, Rio Grande basin: U.S. Geological Survey Water-Data Report CO 78-1, 415 p. [Available only from the National Techical Information Serveice, Springfield, VA 22161] 1986, Water resources data for Colorado--Water year 1986, Volume 1, Missouri River basin, Arkansas River basin, Rio Grande basin: U.S. Geological Survey Water-Data Report CO 86-1, 345 p. [Available only from the National Technical Information Service, Springfield, VA 22161]

Whittemore, R.C., 1985, Modifications to the QUAL-2 water-quality model and user manual for QUAL-2E version 2.2: National Council of the Paper Industry for Air and Stream Improvement, Technical Bulletin no. 457, 1 volume.

Willingham, W.T., 1976, Ammonia toxicity: Denver, Colorado, U.S. Environmental Protection Agency, Region VIII, EQA-908/3-76-001, 20 p. 
SUPPLEMENTAL INFORMATION 


\section{Modification of the Model for Application}

to Monument and Fountain Creeks

As was noted in the "Description of Steady-State Stream Water-Quality Model" section of this report, several modifications were made to the QUAL2E model for the analysis described in this report. The following sections of this report describe the most important modifications and the reasons the modifications were made. Although the capability to output line-printer plots of the constituents simulated in the present analysis was a substantial modification to the QUAL2E model, description of this modification is beyond the scope of this report.

\section{Addition of the Capability to Use a Different Computational- Element Length for Each Subreach}

For operation of the QUAL2E model, a stream to be simulated is divided into one or more subreaches, which, in turn, are divided into one or more computational elements. The model was designed to use only one length for the computational elements of all subreaches (Brown and Barnwel1, 1987, p. 71). However, the use of a uniform computational-element length was considered to be inappropriate for Monument and Fountain Creeks because: (1) One or more of the many tributaries, diversions, and wastewater inflows sometimes are located close to each other and (2) imprecise positioning of computational elements used to compare simulated concentrations of water-quality constituents would affect the quantitative acceptability criterion (see "Acceptability Criteria for Calibration and Verification" section of this report).

Although a uniform computational-element length of about $0.1 \mathrm{mi}$ probably would be acceptable for use in the present analysis, the number of computational elements required would be large (a line of printed output is generated for each computational element for each component of the model output). Modification of the model to allow a different computational-element length for each subreach required about one-half the number of elements as the uniform use of $0.1 \mathrm{mi}$, while providing more precise positioning of tributaries, diversions, wastewater outfalls, and sampling sites.

\section{Modification of Stream-Temperature Estimating Method}

Variables used in the computation of stream temperature include latitude and longitude of the basin, time of year (Julian date), two evaporation coefficients, elevation, barometric pressure, wet- and dry-bulb air temperature, wind velocity, cloud cover, and a dust-attenuation coefficient (Brown and Barnwell, 1987, p. 51). The model was modified to simplify the data input for some of these variables and to improve the estimation of temperature.

Of the temperature computation variables listed in the previous paragraph, only single values for latitude, longitude, time of year, and evaporation coefficients could be specified; however, subreach variable values of elevation, barometric pressure, wet- and dry-bulb air temperature, wind velocity, cloud cover, and a dust-attenuation coefficient could be specified. 
Latitude, longitude, and time of year are easily determined and single values clearly are adequate. Values for the two evaporation coefficients were estimated by following the formulations described in Brown and Barnwe11 (1987, p. 67-68) and by using climatologic data for Colorado Springs and Pueblo (National Oceanic and Atmospheric Administration, 1988a and 1988b). The estimated initial values were adjusted during the temperature estimation process and are not presented here.

Subreach-variable values for elevation and barometric pressure can be used for model input and were needed for the present analysis because they vary considerably in the study area. Elevation for each subreach (tables 4 and 5) was easily estimated from available topographic maps. Although barometric-pressure data were obtained during the water-quality sampling periods and could be used to estimate subreach barometric-pressure values for the calibration and verification simulations, more general barometric-pressure values would be needed for future simulations.

Barometric pressure is correlated to elevation. General values for barometric pressure can be computed from elevation by using the equation (Doug Cain, U.S. Geological Survey, written commun., 1983):

$$
\mathrm{BP}=760-(\mathrm{EL} \times 0.025),
$$

where $\mathrm{BP}=$ subreach barometric pressure, in millimeters of mercury; and EL = median subreach elevation, in feet.

Rather than compute barometric pressure for each subreach with equation 14 and include the results in the input data, equation 14 was programed into the model for computation of subreach barometric pressure from subreach elevation.

Air temperature also is correlated to elevation; this correlation was used to provide a means to compute wet- and dry-bulb air temperatures for each subreach. The change in air temperature with change in elevation is commonly known as lapse rate. Long-term monthly temperature data available for Colorado Springs and Pueblo (National Oceanic and Atmospheric Administration, $1988 \mathrm{a}$ and $1988 \mathrm{~b}$ ) were used to derive a temperature lapse-rate equation for the study area.

First, the correlation between the monthly wet-bulb temperatures at Colorado Springs and at Pueblo and the correlation between the monthly dry-bulb temperatures was analyzed using least-squares regression. The two regressions have coefficients of determination of 0.97 and 0.99 , and the slopes are 1.16 and 1.17 (a 0 -intercept was used for the regressions). Because the regressions were practically identical, a single regression between wet- or dry-bulb temperatures at Colorado Springs and those at Pueblo was derived. For the regression, the coefficient of determination is 0.98 , the standard error of estimate is $1.4^{\circ} \mathrm{C}$, and 24 data pairs were used.

Results of the equation were programed into the model. Monthly wet- and dry-bulb temperature data for the Colorado Springs weather station, as well as the station elevation, are included in the input data. The subreach wet- and dry-bulb air temperatures are computed by using the lapse-rate equation and the difference in elevation between a subreach and the Colorado Springs weather station. 
Additional analysis of the long-term monthly climatologic data for Colorado Springs and Pueblo indicated that monthly average wind velocity and elevation also correlate. The relation between monthly wind velocity at Colorado Springs and at Pueblo was derived by linear least-squares regression. For the regression, the coefficient of determination is 0.82 , the standard error of estimate is 0.18 miles per hour, and 12 data pairs were used. On the basis of the regression results, a wind velocity-elevation relation, similar to the temperature lapse-rate relation, was programmed into the model; the monthly wind-velocity data for Colorado Springs also are included in the input data.

Cloud-cover data also were available from the climatologic data; a uniform value was initially used for all subreaches. Because no data were available to establish a suitable value for the dust-attenuation coefficient, an initial value of 0.13 (Brown and Barnwel1, 1987, p. 65) was used for all subreaches.

The methods just described to estimate subreach values for four temperature-computation variables on the basis of only subreach elevation and readily available monthly climatologic data simplified the input of data for these variables. This capability aided the calibration and verification of the model and will benefit future applications of the model to Monument and Fountain Creeks, because subreach values of barometric pressure, wet- and dry-bulb air temperatures, and wind velocity will not need to be determined for each application to a different time of year.

Because only single values for the two evaporation coefficients could be specified in the input data, only the subreach-variable values for cloud cover and the dust-attenuation coefficient were available for adjustment to ensure that estimated stream temperatures were reasonable. Even large adjustments of these two variables resulted in little change in estimated stream temperature. However, small changes in the two evaporation coefficients resulted in large changes in estimated stream temperature. Nevertheless, reasonable estimation of stream temperature for all subreaches could not be achieved by the adjustment of the two evaporation coefficients and the subreach-variable cloud cover and dust-attenuation coefficient.

Therefore, additional modifications were made to the model to use subreach-variable values of the two evaporation coefficients and only single values of cloud cover and dust-attenuation coefficient. Reasonable estimation of stream temperature then was readily achieved. The reasons that this modification resulted in improved stream-temperature estimation probably are related to two factors: (1) The large value for the latent heat of water vaporization, which is about 1,050 BTU at $15.6{ }^{\circ} \mathrm{C}$ (Brown and Barnwe11, 1987, p. 67) and (2) the large rates of evaporation in the study area (Farnsworth and others, 1982, map 3). Finally, adjustment of the two evaporation coefficients indicated that estimated stream temperature was more sensitive to one coefficient than the other. Therefore, the less sensitive coefficient was assumed to be constant, and the more sensitive coefficient (tables 4 and 5 ) was adjusted to provide the best overall stream-temperature estimation (see "Estimated Stream Temperatures" section of this report). 
Other Modifications to the Model

The "Estimation of Un-ionized Ammonia" section of this report provides a detailed discussion of the methods programmed into the model to compute un-ionized ammonia. The computer code for the computation of un-ionized ammonia follows. The call to the subroutine is made in the QUAL2E program main just before the output subroutines are called.

The model also was modified for the use of a nitrate decay coefficient (see "Reaction Coefficients" section of this report) and to provide the capability to use additional reaeration equations (see "Reaeration Data" section). Finally, the QUAL2E model allows for input of data and output of results in either U.S. customary or metric units; the units specified for input can be different from those specified for output (Brown and Barnwel1, 1987 , p. 3). Data used in the present analysis were suitable for use with U.S. customary units, with the exception of stream temperature. In using U.S. customary units with the model, input or output stream temperature is given in degrees Fahrenheit, whereas the stream-temperature data obtained for the study were in degrees Celsius. Because it was preferable to use degrees Celsius for input and output of temperature, modifications were made to the model to provide this capability when using U.S. customary units.

\section{Computer Code for Un-ionized Ammonia Subroutine}

C

SUBROUTINE UIONZD (T, CONS, CNH3, NREACH, ICLORD, NCELRH, MR, MC, $\&$ UI_AMM, COINIT)

$\mathrm{C}$

C th* SUBROUTINE CREATED TO COMPUTE (ESTIMATE) UN-IONIZED AMMONIA

C ON THE BASIS OF MODEL-COMPUTED TEMPERATURE (T(IOR) ARRAY), DISSOLVED

C SOLIDS (CONS (IOR,1) ARRAY) AND TOTAL AMMONIA (CNH3(IOR) ARRAY), AND ON

C THE BASIS OF PH VALUES FOR EACH REACH, READ IN AS CONSERVATIVE

C MINERAL II (COINIT(NRCH,2) ARRAY) IN DATA TYPE 7.

C PH FOR EACH ELEMENT IS GENERATED IN THIS SUBROUTINE FROM THE INITIAL

C PH VALUES READ IN FOR EACH REACH.

C

DIMENSION T(MC), CONS (MC , 3), CNH3 (MC), ICLORD (MR , 20), NCELRH(MR),

\& UI_AMM(MC), COINIT $(M R, 3), \operatorname{TABLT}(70), \operatorname{PKA}(70,9), \operatorname{TABLDS}(9)$

REAL T, CONS, CNH3 , PH, UI AMM, COINIT , TABLT, PKA, TABLDS

INTEGER ICLORD, NCELRH, NREACH, IOR

C

DATA TABLDS $/ 0.0,250 ., 500 ., 750 ., 1000 ., 1500 ., 2000 ., 3000 ., 5000 . /$

DO $5 \mathrm{I}=1, \mathrm{MC}$

5 UI_AMM(I) $=0.0$

C

C

C

DO $10 I=1,70$

$\operatorname{TABLT}(I)=0.0$

DO $10 \mathrm{~J}=1,9$

$\operatorname{PKA}(I, J)=0.0$

10 CONTINUE 


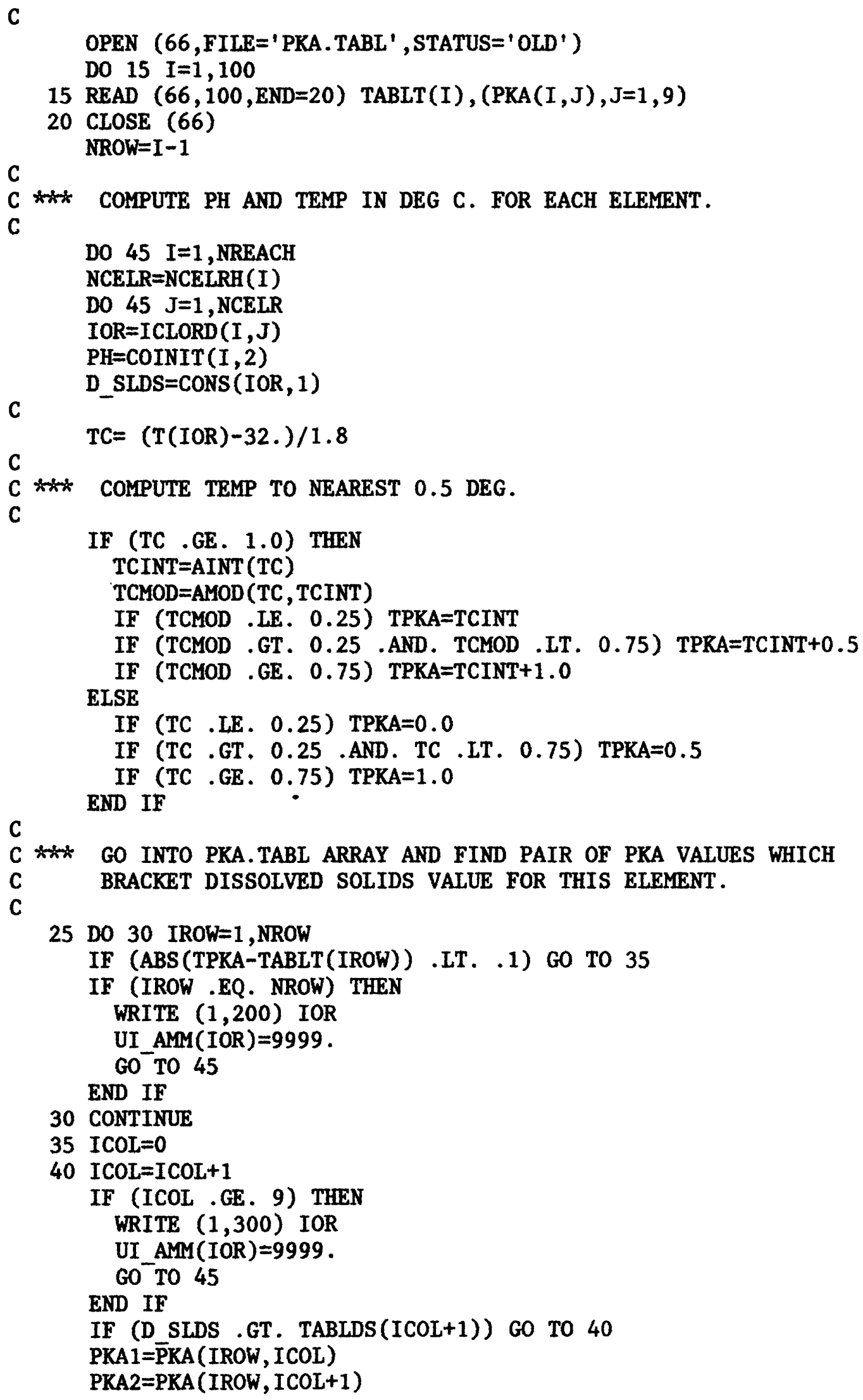


$\mathrm{C}$

C * FIN PKA DIFFERENCE AND PRO-RATE FOR CURRENT DS. SOLIDS VALUE.

C

PKDIFF=PKA2-PKA1

PKINCR=PKDIFF $/($ TABLDS $($ ICOL+1) - TABLDS $($ ICOL $))$

$\mathrm{C}$ CPKA $=$ PKA $1+$ PKINCR $\approx$ D SLDS

C COMPUTE UNIONIED AMMONIA ON BASIS OF COMPUTED CPKA AND PH.

C

45 CONTINUE

FACT UN $=1.0 /(10 * *(\mathrm{CPKA}-\mathrm{PH})+1$.

UI_AMMM (IOR) $=$ CNH3 $($ IOR $) *$ FACT_UN

$\mathrm{c}$

RETURN

C

100 FORMAT (F4.1,9(F8.3))

200 FORMAT (5X,' TEMP. EXCEEDS 31.0 DEG. C AT ELEMENT ',I3, $\&$ '--UNIONIZED AMMONIA NOT COMPUTED')

300 FORMAT (5X,'DIS. SOLIDS EXCEEDS 5,000 MG/L AT ELEMENT ',I3, $\&$ '--UNIONIZED AMMONIA NOT COMPUTED')

C END 